\title{
Regional stratigraphic framework of the Tuscarora Sandstone: A model for geologic CO2 storage in West Virginia
}

Christian T. Kramer

West Virginia University

Follow this and additional works at: https://researchrepository.wvu.edu/etd

\section{Recommended Citation}

Kramer, Christian T., "Regional stratigraphic framework of the Tuscarora Sandstone: A model for geologic CO2 storage in West Virginia" (2013). Graduate Theses, Dissertations, and Problem Reports. 331. https://researchrepository.wvu.edu/etd/331

This Thesis is protected by copyright and/or related rights. It has been brought to you by the The Research Repository @ WVU with permission from the rights-holder(s). You are free to use this Thesis in any way that is permitted by the copyright and related rights legislation that applies to your use. For other uses you must obtain permission from the rights-holder(s) directly, unless additional rights are indicated by a Creative Commons license in the record and/ or on the work itself. This Thesis has been accepted for inclusion in WVU Graduate Theses, Dissertations, and Problem Reports collection by an authorized administrator of The Research Repository @ WVU. For more information, please contact researchrepository@mail.wvu.edu. 


\title{
Regional stratigraphic framework of the Tuscarora Sandstone: A model for geologic $\mathrm{CO}_{2}$ storage in West Virginia
}

\author{
Christian T. Kramer \\ Thesis submitted to the \\ College of Arts and Sciences \\ at West Virginia University \\ in partial fulfillment of the requirements \\ for the degree of \\ Master of Science \\ in Geology
}

Dr. Timothy Carr, Ph.D., Chair

Dr. Richard Smosna, Ph.D.

Dr. Jaime Toro, Ph.D.

Department of Geology and Geography

Morgantown, West Virginia

2013

Keywords: Tuscarora Sandstone; Sequence Stratigraphy; Carbon Sequestration; West Virginia; Appalachian Basin; Lower Silurian 


\begin{abstract}
Regional stratigraphic framework of the Tuscarora Sandstone: A model for geologic $\mathrm{CO}_{2}$ storage in West Virginia
\end{abstract}

\title{
Christian T. Kramer
}

Evaluation of the regional resource potential for geologic storage of anthropogenic greenhouse gases, primarily $\mathrm{CO}_{2}$, is an essential first step in developing policies for carbon management. Within the central Appalachian basin the Lower Silurian Tuscarora Sandstone, a gas producing anticlinal play, has been identified as a potential $\mathrm{CO}_{2}$ storage target. The Tuscarora extends from New York to Tennessee and is dominantly a white to light-gray, silicacemented orthoquartzite deposited in a fluvial and/or littoral environment. The objective of this study is to analyze the Tuscarora Sandstone in West Virginia to determine its potential for geologic storage of $\mathrm{CO}_{2}$, as well as using additional new well data to develop a sequence stratigraphic framework to understand the depositional environment and the effect on regional reservoir quality.

In order to evaluate the $\mathrm{CO}_{2}$ storage resource assessment, the Tuscarora Sandstone was divided into three informal units: an upper, middle and lower member. These members were described for their lithology based on four core descriptions, well cuttings from twenty three wells and four outcrop descriptions. The depositional facies identified for the lower member are a tidal-influenced fluvial sandstone in the northeast as well as a channel fill in shallow incised valleys to the southeast. Carbonate beds present in the lower member in the southwest are interpreted as shallow marine. The middle member is generally a dark-gray shale deposited in a storm-dominated offshore marine environment in the west and deposited in a muddy embayment to the northeast. Finally, the upper member is fine- to coarse-grained and locally conglomeratic, and interpreted as stacked fluvial sandstone beds in the east, transitioning into incised valleys in the west, with increasing marine influence downdip. Increased marine energy is interpreted towards the top of the upper member as grain size decreases and biologic features increase. An increase in shale content to the west also indicates increased marine energy.

Using the lithologic descriptions and approximately 175 wells with partial-to-full log suites, the units were placed into a T-R sequence stratigraphic model to understand the depositional environments of Tuscarora Sandstone. The lower and middle members are grouped into a transgressive systems tract (TST), with a maximum flooding surface (MFS) occurring within the middle member. Above this MFS is the regressive systems tract (RST) which includes the lower portion of the upper member. Within the upper member, a transgression occurs with a second sequence that continues upwards into the overlying Rose Hill Formation.

The Tuscarora Sandstone is typically a low porosity and low permeability sandstone. Good reservoir properties such as higher than normal porosity and permeability, are observed in the coarse-grained deposits of the RST. Two potential injection intervals for $\mathrm{CO}_{2}$ storage are identified in the sand-rich lower and upper members. The unrisked calculated storage volume of the lower member and upper is $5.26 \times 10^{9}$ metric tons and $4.21 \times 10^{10}$ metric tons, respectively. The high volumes, especially in the upper member, reflect the great thickness and geographic extent of the Tuscarora Sandstone in West Virginia; smaller scale studies are strongly encouraged. 


\section{ACKNOWLEDGEMENTS}

First and foremost, I would like to thank my advisor Dr. Timothy Carr for agreeing to take me on for this project, as well as for his patience, funding and very useful input for the entirety of this project. I also extend my sincere gratitude to my committee members Dr. Richard Smosna and Dr. Jaime Toro for agreeing to be a part of this project. Dr. Smosna, thank you for all of your suggestions, for allowing me to keep you from fully retiring and thank you for our many long discussions on Friday afternoons. Dr. Toro, thank you for always being a reliable source of extensive geologic knowledge and giving me advice when needed.

I am also greatly appreciative of the faculty and financial support of the West Virginia University Department of Geology. A thank you is also due to Consol Energy and WPX Energy for the experience and knowledge gained during summer internships. Additionally, I would like to thank the DOE/NETL for funding this project. Finally, I would like to express my appreciation to my parents for their continued support and encouragement throughout my entire educational journey. 


\section{Table of Contents}

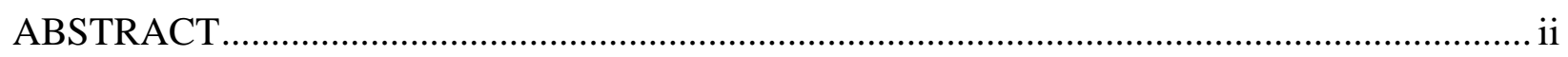

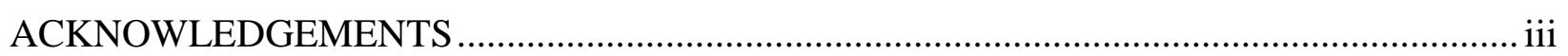

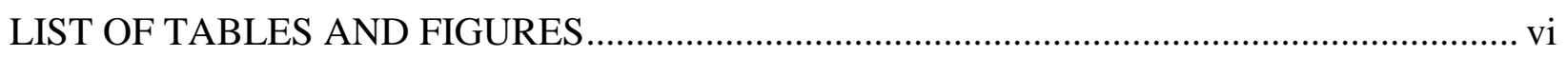

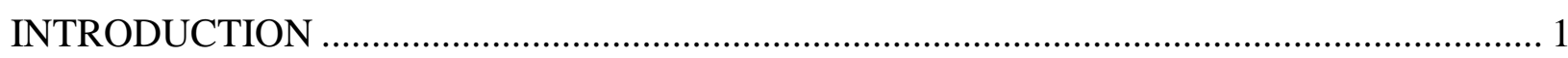

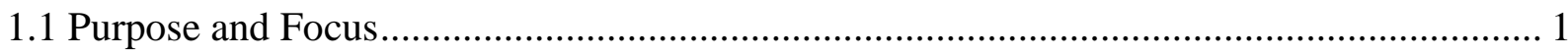

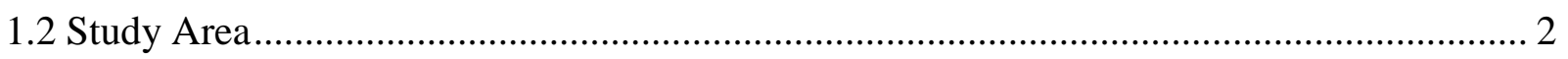

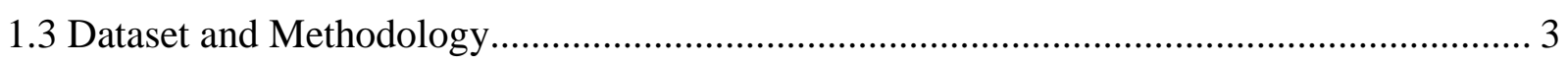

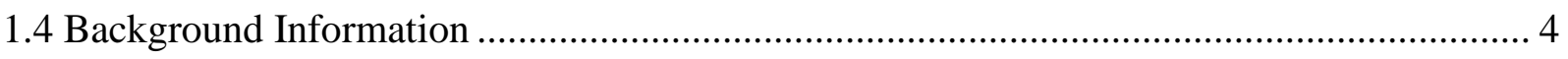

1.5 Previous Work

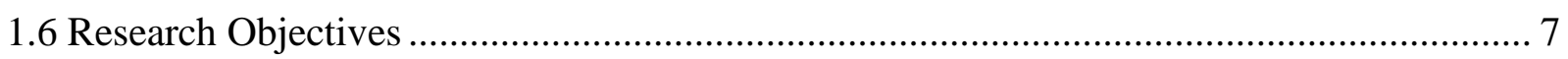

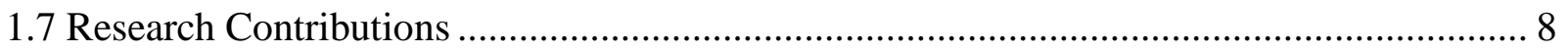

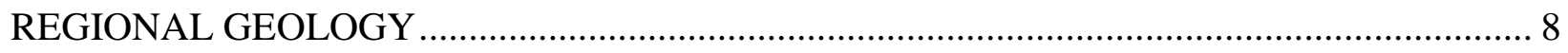

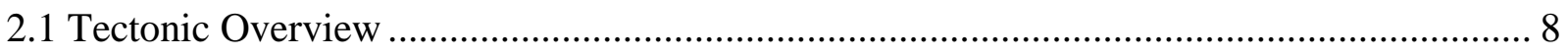

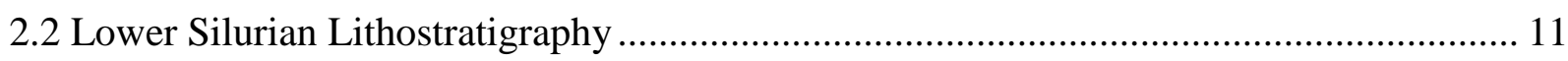

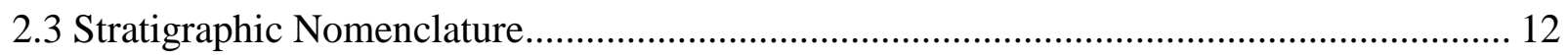

2.4 Depositional Environments: Previous Interpretations........................................................ 15

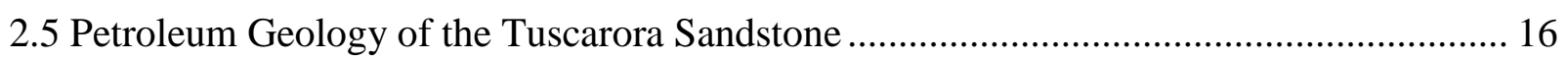

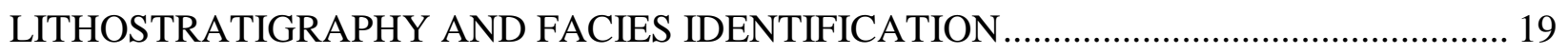

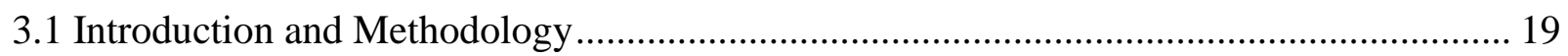

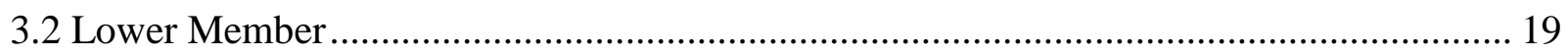

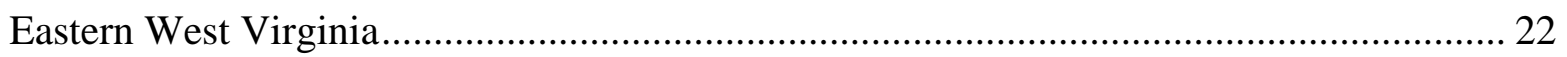

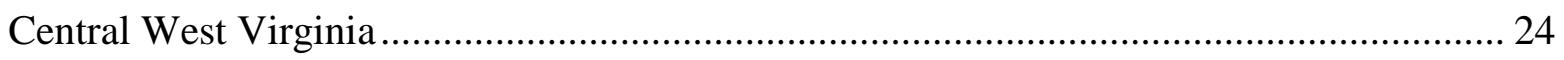

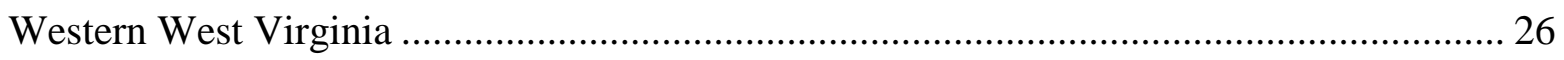

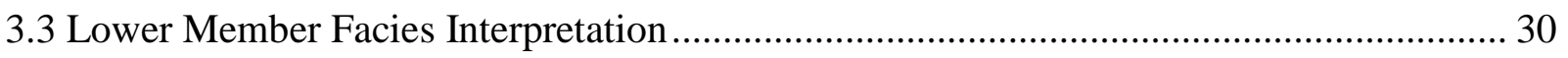

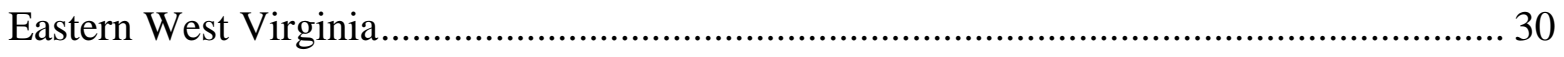

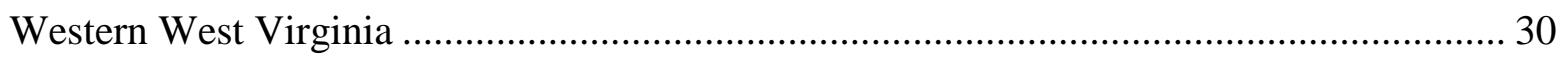

Lower Member Isopach and Paleoenvironment Map........................................................ 33

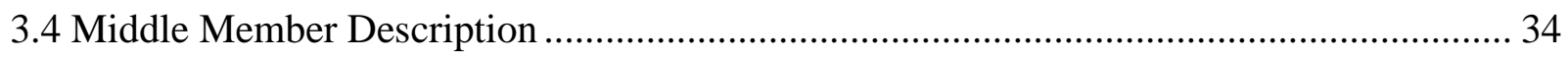

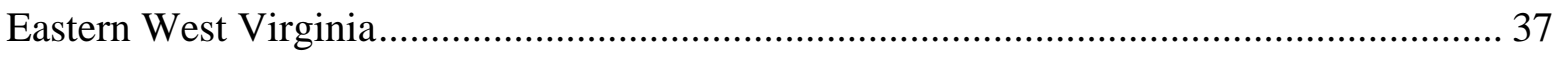

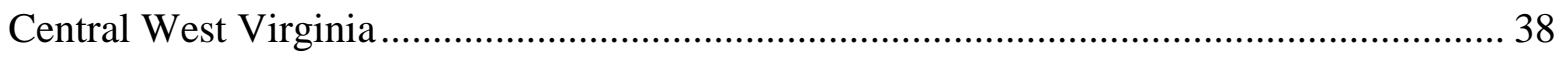

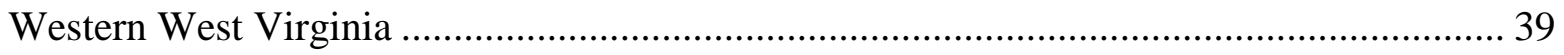

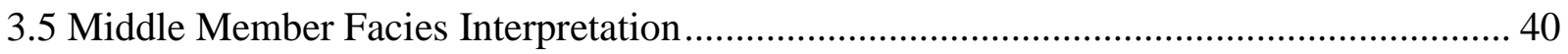

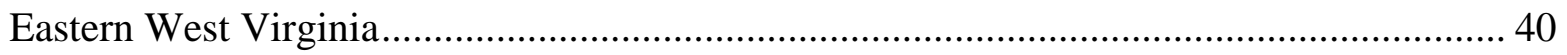




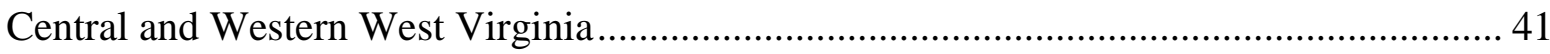

Middle Member Isopach and Paleoenvironment Map ……………..................................... 41

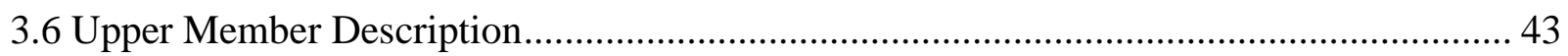

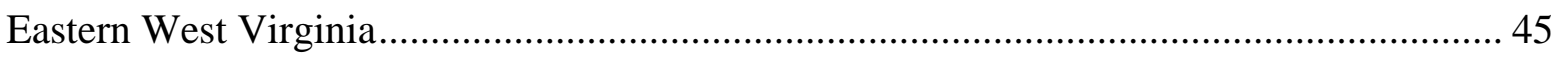

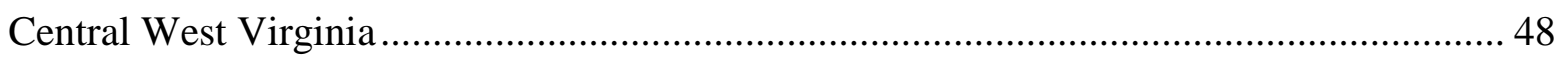

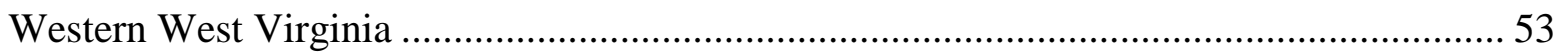

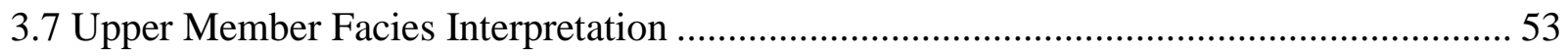

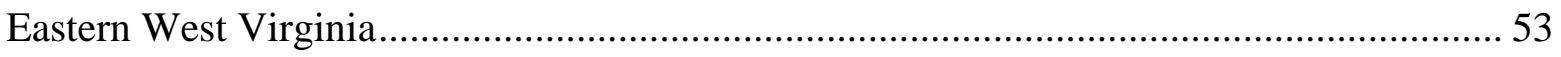

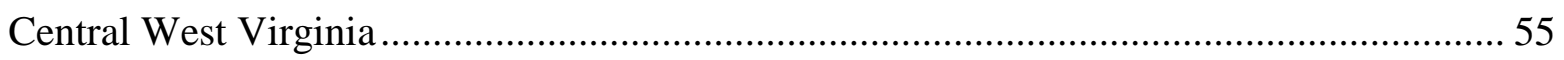

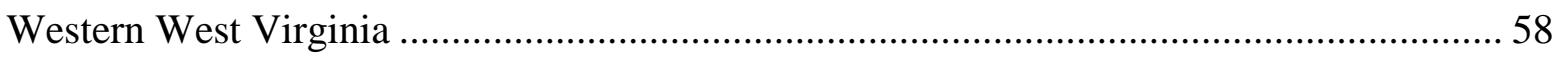

Upper Member Isopach and Paleoenvironment Map ....................................................... 59

Gross Tuscarora Sandstone and Rose Hill Formation Isopach Maps .................................... 61

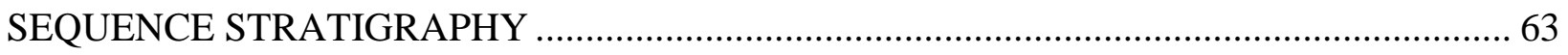

4.1 Discussion on Stratigraphic Surfaces and Sequence Stratigraphy ……............................... 63

4.2 Regional correlations of significant stratigraphic surfaces and systems tracts ................... 69

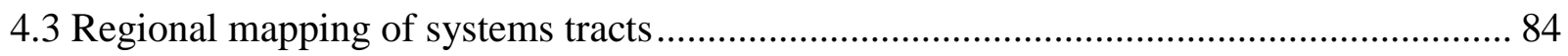

4.4 Discussion on systems tracts and reservoir properties .................................................... 87

REGIONAL MAPPING OF RESERVOIR PROPERTIES ………….................................. 89

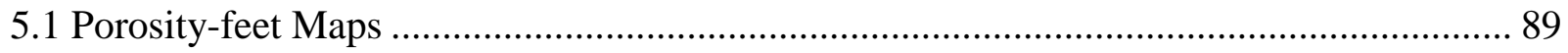

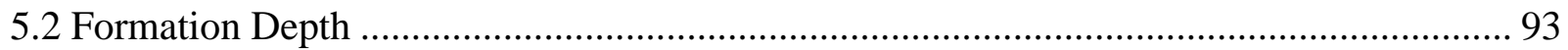

5.3 Temperature and Pressure Maps ……………………..................................................... 95

$\mathrm{CO}_{2}$ STORAGE CAPACITY IN THE TUSCAORA SANDSTONE IN WEST VIRGINIA.... 100

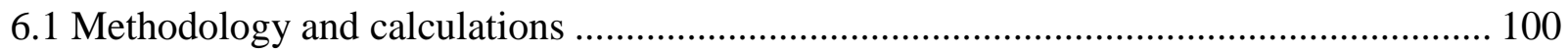

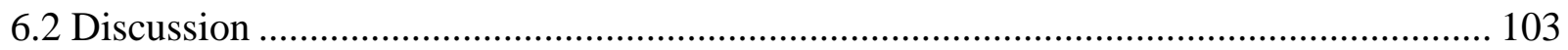

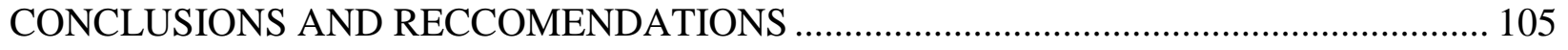

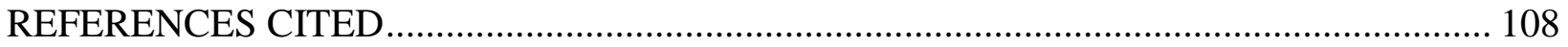

APPENDIX I: Regional Lithostratigraphic Correlations ......................................................... 117

APPENDIX II: Sample Descriptions ..................................................................................... 131 


\section{LIST OF TABLES AND FIGURES}

Figure 1: Location of study area and dataset ………………................................................. 3

Figure 2: Paleogeography of the Appalachian basin during Silurian time. ................................. 10

Figure 3: Stratigraphic nomenclature of the Lower Silurian strata in the Appalachian basin...... 13

Figure 4: Play outline, fields, pools and location of inert gases in the Tuscarora gas play .......... 18

Figure 5: Lower member type logs and locations.................................................................. 20

Figure 6: Core description of the lower member in Preston County........................................... 23

Figure 7: Core photographs of the lower member in Preston County.......................................... 23

Figure 8: Neutron-density crossplot of the lower member in the Indian Creek field ................... 25

Figure 9: Neutron-density crossplot of the lower member in Cabell County ............................... 27

Figure 10: Neutron-density crossplot of the locally-occurring basal sandstone............................ 29

Figure 11: Southwest to northeast cross-section of the basal sandstone. …………...................... 32

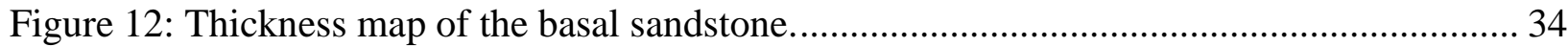

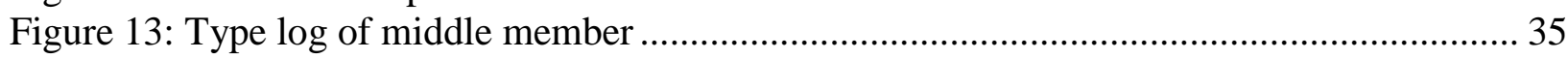

Figure 14: Core description of the middle member in Preston County ........................................ 37

Figure 15: Core photographs of the middle member in Preston County ....................................... 38

Figure 16: Featured sedimentary structures of the middle member in core from Clay County ... 39

Figure 17: Thickness map and paleoenvironment of the middle member................................... 42

Figure 18: Four type logs and well locations of the upper member ............................................ 43

Figure 19: Core photographs of the upper member from Preston County .................................... 46

Figure 20: Neutron-density crossplot of the upper member in Fayette County. ........................... 47

Figure 21: Gamma ray log and corresponding core description of the upper member ................ 49

Figure 22: Core photographs of the upper member from Kanawha County. ……………...........5 50

Figure 23: Core photographs of the upper member from Clay County .......................................... 52

Figure 24: Relative energy levels and sedimentary facies in a wave-dominated estuary.............5 58

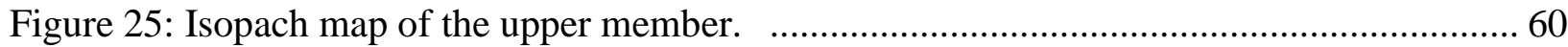

Figure 26: Thickness map and interpreted depositional environments of the upper member...... 61

Figure 27: Interpreted depositional environment of the upper member after rise in sea-level..... 61

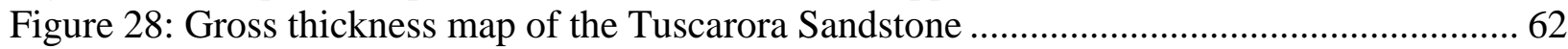

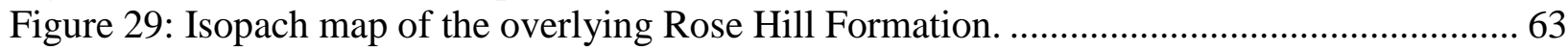

Figure 30: Chart comparing and contrasting systems tracts of the T-R model. ............................6 65

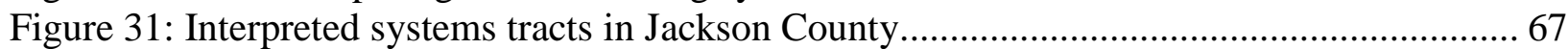

Figure 32: Orientation of 6 along-dip and 4 along-strike lines of section ................................. 70

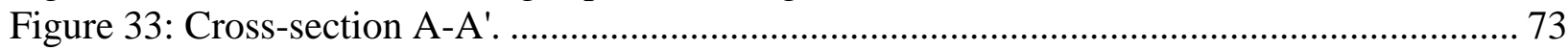

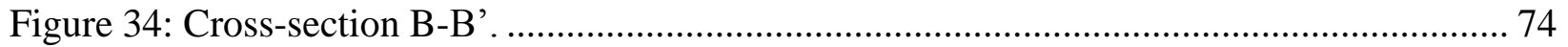

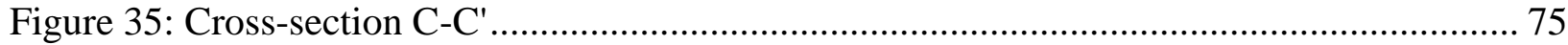

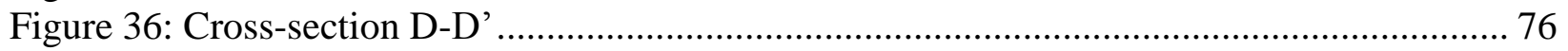

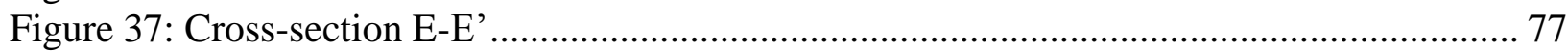

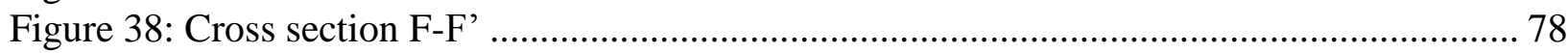

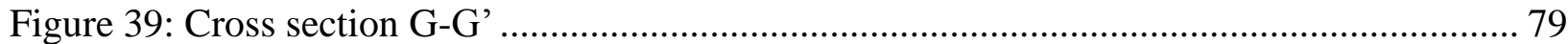

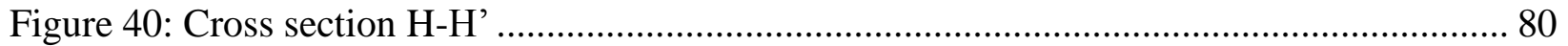

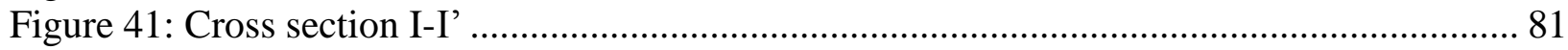

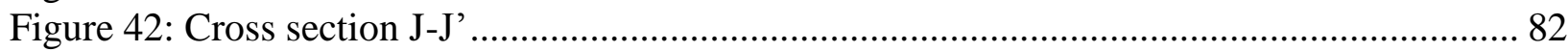

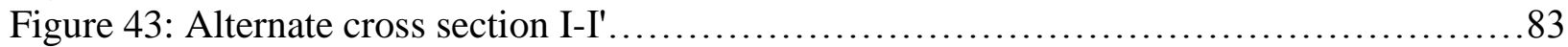

Figure 44: Isopach map of the first transgressive sytems tract (TST 1) ..................................... 84

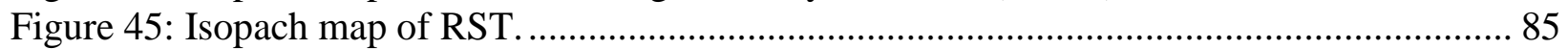




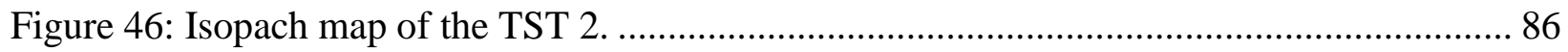

Figure 47: Example of good reservoir properties related to lithofacies.......................................... 88

Figure 48: Porosity-feet map of the lower member .............................................................. 90

Figure 49: Cross section A-A' through the porosity-feet trend of the basal sandstone................. 91

Figure 50: Porosity-feet map of the upper member with a 50 API cutoff ................................... 92

Figure 51: Porosity-feet map with major anticlines.................................................................. 93

Figure 52: Depth map of the top of the Tuscarora Sandstone relative to sea level ..................... 95

Figure 53: Uncorrected and corrected formation temperatures of the Tuscarora Sandstone ....... 97

Figure 54: Corrected formation temperatures of the Tuscarora Sandstone. …………….............. 98

Figure 55: Calculated pressure at formation depth ……………………………..................... 99

Figure 56: $\mathrm{CO}_{2}$ storage potential in metric tons of the lower member in West Virginia............. 101

Figure 57: $\mathrm{CO}_{2}$ storage potential in metric tons of the upper member in West Virginia. ........... 102

Figure 58: Orientation of selected eleven cross-sections in the study area. .............................. 118

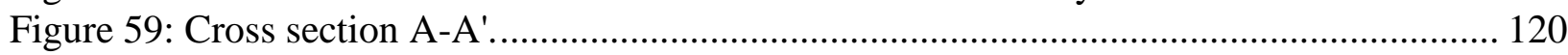

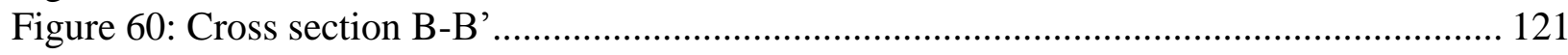

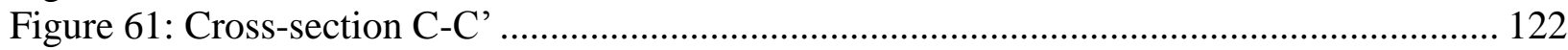

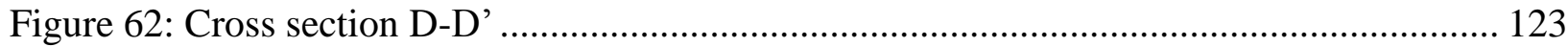

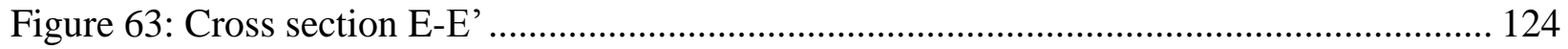

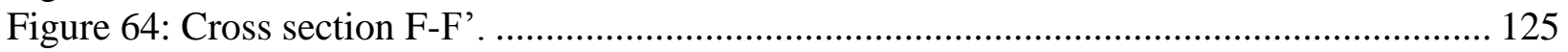

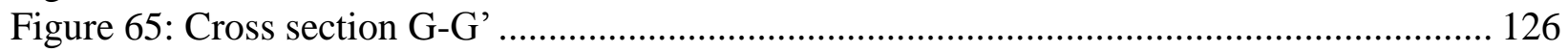

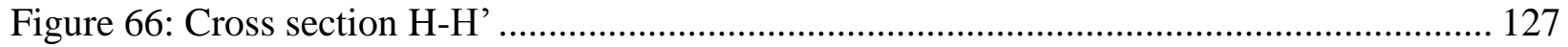

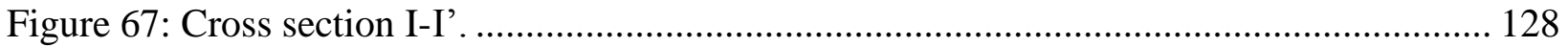

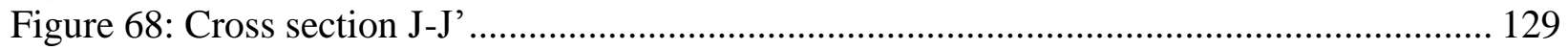

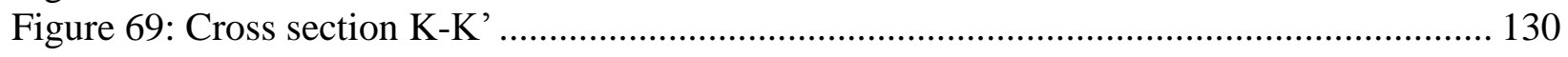

Table 1: Previously interpreted unconformities within the Tuscarora Sandstone ........................ 11

Table 2: Previous descriptions and interpretations of the lower member...................................... 21

Table 3: Selected list of previously descriptions and interpreted depositional environments of the

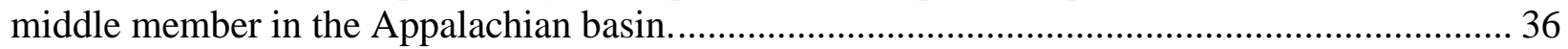

Table 4: Previously described and interpreted depositional environments of the upper member in

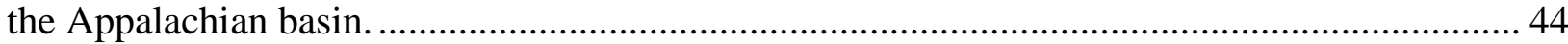




\section{INTRODUCTION}

Fossil fuels are essential for economic prosperity; however, there should be a balance between energy security and the concern with minimizing global climate change. In addition to improving energy efficiency, energy conservation, and using non-carbon energy sources, mitigating technologies and strategies must be developed and implemented in order to stabilize the concentration of atmospheric greenhouse gases, notably carbon dioxide $\left(\mathrm{CO}_{2}\right)$, which is the most significant contributor to climate change. A technology receiving considerable research and development is carbon capture and storage (CCS) or carbon sequestration. CCS technology involves injecting supercritical $\mathrm{CO}_{2}$ into deep subsurface geologic formations overlain by competent seals that will prevent $\mathrm{CO}_{2}$ from migrating to shallower depths and potentially leaking into the atmosphere.

The Tuscarora Sandstone in the Appalachian basin is identified as one of several potential target formations in the basin for carbon sequestration due to its demonstrated integrity to store and produce natural gas. The Tuscarora extends from New York to Tennessee and is quartz-rich and conglomeratic containing thin beds of shale (Smosna and Patchen, 1978; Avary, 1996). Factors used in evaluating deep-hydrocarbon producing units for $\mathrm{CO}_{2}$ injection potential include: depth, porosity, permeability, injectivity, productivity, and reservoir pressure. Although the Tuscarora is considered to be a tight-gas formation due to low porosity and permeability, it is being considered for CCS due to its history of storing and producing economic quantities of hydrocarbons.

\subsection{Purpose and Focus}

One goal of this study is to calculate the potential for geologic storage of $\mathrm{CO}_{2}$ in the 
Tuscarora Sandstone in West Virginia. To accomplish this goal a regional stratigraphic framework is created to evaluate the extent of depositional environments. A sequence stratigraphic approach was employed in order to subdivide sequences into systems tracts allowing for a higher degree of facies predictability, which is vital in a reservoir analysis and assists in identification of potential injection reservoirs (Van Wagoner et al., 1990).

\subsection{Study Area}

The study area is the state of West Virginia, which is 24,230 square miles $(38,994$ square kilometers), located within the central Appalachian basin. The majority of the study area is located in the subsurface within the Appalachian plateau province. The eastern boundary of this plateau is the northeast-southwest running Allegheny front. Most of the Tuscarora Sandstone in the study area is located in the subsurface, however, to the east it crops out in the Valley and Ridge province in a series of folded mountains and valleys (Figure 1).

Within the study area the depth of Tuscarora Sandstone ranges from 2,125 to $-9,506$ feet subsea (648 to $-2,897$ meters) with an average depth of $-5,842$ feet $(-1,780 \mathrm{~m})$. The thickness of the Tuscarora Sandstone ranges from less than 100 feet (30 meters) in western West Virginia to accumulations greater than 1,000 feet (304 meters) in northeastern Pennsylvania (Smosna and Patchen, 1978). 


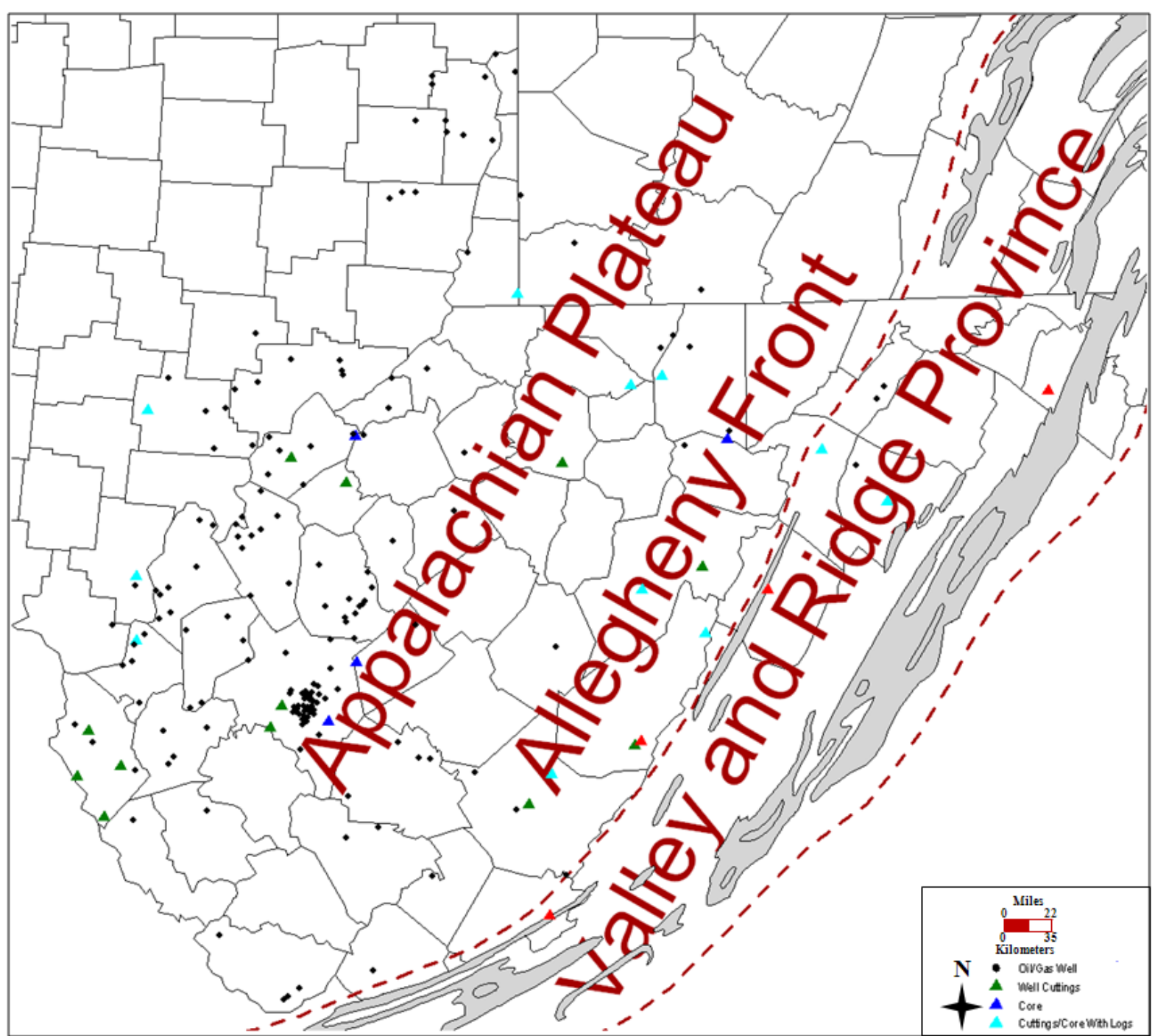

Figure 1: Location of study area (West Virginia), physiographic provinces and wells with available log data, well cuttings, core, and outcrop locations. Gray shaded areas to the east are outcrop locations of the Tuscarora Sandstone.

\subsection{Dataset and Methodology}

The dataset consists of 175 wells with partial-to-full log suites, four core descriptions, and twenty-three well sample descriptions. Wells located in eastern Ohio and southwestern Pennsylvania counties are incorporated in order to enhance the regional perspective of depositional environments (Figure 1). In order to place the Tuscarora into a sequence stratigraphic framework, significant surfaces were identified in previous core descriptions. Relevant raster logs (gamma ray, neutron porosity and density porosity) were downloaded from a commercial source (TGS), imported into geologic software (IHS Petra) and digitized. Facies 
were integrated with significant surfaces through the use of core descriptions, photographs, raster, and digital log ASCII standard (LAS) logs. Wireline logs were used for correlation in West Virginia to produce a sequence stratigraphic framework of the Tuscarora Sandstone. By identifying specific depositional environments and related reservoir properties, a facies evaluation of the Tuscarora Sandstone will allow for identification of potential reservoirs with favorable reservoir properties.

Cross-sections, porosity-feet maps, depth maps, and formation isopach and structure contour maps were constructed. Cross-sections allow for a 2D subsurface view of the lateral extent and geometry of facies. Porosity-feet maps are useful for identifying areas with higher pore volumes. Depth and structure maps are used to determine the subsurface formation depths and any significant subsurface structures, both of which are significant criteria in a CCS evaluation. Thickness maps are used to identify thickness trends and areas of potential high storage volumes. Additionally, geophysical logs were used to create crossplots in order to identify the mineralogy in differing facies.

\subsection{Background Information}

The onset of the Industrial Revolution in the $19^{\text {th }}$ century brought about anthropogenic activities that have raised carbon dioxide levels from 280 parts per million (ppm) to $379 \mathrm{ppm}$ over the last 150 years (IPCC, 2007). The largest contribution to the increase in greenhouse gas concentrations is the burning of fossil fuels: in $200976 \%$ of emissions were related to combustion of coal and petroleum fuels and $24 \%$ came from natural gas combustion (EIA, 2011). A substantial decrease in $\mathrm{CO}_{2}$ emissions is believed necessary in order to mitigate continued increases of GHG concentrations in the atmosphere. 
Sequestering $\mathrm{CO}_{2}$ in deep geologic formations may be a feasible solution to curbing atmospheric concentrations because of our knowledge of and experience in oil and gas production, natural gas storage, and groundwater resource management (Bachu, 2001) Geologic reservoirs have contained oil, gas, water, and $\mathrm{CO}_{2}$ for millions of years with either minimal or no leakage, so it can be assumed that these same systems will accommodate near- and long-term solutions for storage (Reichle et al., 1999; Beecy et al., 2002).

The process of geologic storage of $\mathrm{CO}_{2}$ begins at its capture at the point source where it is purified and compressed for transformation into a supercritical fluid and transported to the injection site. Targeted reservoirs include: depleted oil and gas reservoirs, deep saline aquifers, unmineable coal seams, and basalts. Several in-situ reservoir characteristics must be considered in the selection of geologic $\mathrm{CO}_{2}$ storage targets such as: depth, temperature, pressure, rockvolume, porosity, as well as the density of $\mathrm{CO}_{2}$ at formation depth (Bachu, 2001).

\subsection{Previous Work}

Previous work in the Tuscarora includes petrographic and core analyses (Bruner 1983; Castle and Byrnes, 2005). Bruner (1983) evaluated the Tuscarora in the Indian Creek field in Kanawha County, West Virginia, for the diagenetic and depositional controls that contributed to the preservation or development of porosity. Within the investigation, a core analysis was performed and descriptions of sedimentary structures, visible porosity in thin section, grain size, and cementation variations were made.

In Kanawha County, the Tuscarora Sandstone is an orthoquartzite with minor amounts of illite, feldspars, carbonates, anhydrite, mica, and chert (Bruner, 1983). Secondary quartz is the principal cement, responsible for occupying pore spaces and replacing detrital material and therefore reducing primary porosity. Clays are important preservers of primary porosity as they 
may have likely inhibited nucleation of quartz overgrowths. Bruner (1983) calculated an average porosity of $8.2 \%$ from core and thin section analysis and an average of $174 \mathrm{md}$ for permeability.

Castle and Byrnes' (2005) investigation of Lower Silurian sandstones units in the Appalachian basin integrated rock petrophysical properties, facies analysis, and interpretation of stratigraphic framework in order to improve exploration success. Using twenty-two cored wells and 115 thin sections, porosity and permeability were quantified and a regional model for the application of reservoir prediction was developed. Based on core analysis and petrographic analyses, the Lower Silurian sandstone units were categorized into six depositional facies: upper shoreface, lower shoreface, tidal channel, tidal flat, fluvial, and estuarine. After these models were identified, routine helium and routine porosity were determined for each facies, as well as in-situ Klinkenberg permeability.

Castle and Byrnes (2005) concluded that the upper shoreface facies has some of the highest porosity and permeability values. In contrast the estuarine facies has the lowest porosity and permeability. The depositional facies and petrographic characteristics were then placed into a sequence stratigraphic framework in order to create a reservoir model. Sediment dispersal was associated with uplift and subsidence controlled by the Taconic orogeny: high porosity and permeability sandstones are related to areas of low subsidence and low reservoir properties in areas of high subsidence. They concluded that the more-favorable reservoir quality coincides with a combination of high-energy depositional environments and lower maximum burial depths.

Kostelnik and Carter (2009) characterized potential $\mathrm{CO}_{2}$ sites in the Oriskany Sandstone based on criteria such as core data (porosity and permeability), petrographic evaluation, and geophysical log calculations. Geophysical logs were used to calculate isopach thickness, average porosity, and average porosity-feet. Porosity was recorded from values obtained from density- 
or neutron-porosity curves and where both were available, average porosity was calculated. Additionally, Oriskany core was sampled for porosity and permeability. They ranked Oriskany natural gas plays into four categories (ranked from most to least favorable): 1) combination trap play, 2) updip pinch-out play, 3) fractured Huntersville Chert and Oriskany Sandstone play, and 4) structural play. These plays were ranked and sweet spots were identified based on the following criteria: porosity, permeability, depth, and reservoir thickness. Additionally, they analyzed the integrity of the overlying seal in their investigation by measuring a few feet for porosity.

Barnes et al. (2009) integrated core with well-log-derived net porosity in the Michigan basin to estimate total geological sequestration capacity in the Mount Simon Sandstone. A conventional core analysis was completed and compared to the neutron porosity log data in two wells in order to establish correlations between core-measured porosity, permeability, and logbased porosity values. Once a correlation was created by plotting porosity versus permeability, an effective porosity cutoff was created at $10 \%$ and determined to be a suitable macropore system for their purposes. Based on this functional relationship, pseudo-permeability was generated by using calibrated porosity logs for depths with no core data (E-mail communication with Barnes 2012).

\subsection{Research Objectives}

The goals of this study are to describe the depositional environment, to create the stratigraphic framework, and to perform a resource assessment for $\mathrm{CO}_{2}$ storage of the Tuscarora Sandstone in West Virginia. In order to fulfill these goals and provide an interpretation, the following objectives were completed: 
1) Identification of facies and significant surfaces such as sequence boundaries, maximum regressive surfaces, and/or maximum flooding surfaces in wireline logs;

2) Determination of depositional environments and related reservoir properties;

3) Creation of a sequence stratigraphic framework of the Tuscarora Sandstone in West Virginia using the T-R sequence stratigraphic model; and

4) Calculation of volumes for $\mathrm{CO}_{2}$ storage resource in the Tuscarora Sandstone in West Virginia using the suggested equations of the National Energy and Technology Laboratory (NETL, 2012).

\subsection{Research Contributions}

The main contributions of this study are:

1) Identification of potential storage sites for geologic $\mathrm{CO}_{2}$ storage in the Tuscarora Sandstone

2) Identification of facies and significant stratigraphic surfaces of the Tuscarora Sandstone

3) Development of a sequence stratigraphic model of the Tuscarora Sandstone in West Virginia.

\section{REGIONAL GEOLOGY}

\subsection{Tectonic Overview}

The Appalachian foreland basin formed as a result of the Taconic orogeny during the Middle to Late Ordovician (Ettensohn and Brett, 2002) when the basin was located at a latitude of $20^{\circ}-25^{\circ} \mathrm{S}$ and mostly covered by an epicontinental sea (Van der Voo, 1988; Brett et al., 1990). The orogenic event is generally associated with the onset of deformation and accretion of 
a micro-continent at the North American plate margin during the Middle Ordovician (Shumaker, 1996) (Figure 2). During this time crustal downwarp cratonward of the highlands occurred as a result of the flexural-load (Jacobi, 1981; Quinlan and Beaumont, 1984; Ettensohn, 1994).

Although theories about the orogeny are controversial, the collision zone likely involved interactions of small plates, islands, and back-arc basins and the timing of deformation differed along strike (Ettensohn and Brett, 2002). In West Virginia, the formation of stable shelves created an isolated, northern sedimentary basin in place of the once contiguous Appalachian basin (Smosna and Patchen, 1978).

During the middle to late orogenic phase there was a major collisional episode that corresponds to a high rate of crustal uplift along the fold-thrust, coincident with a high subsidence rate in the foreland basin; during this time the influence of tectonism was greater than the influences of eustasy (Castle, 2001). After rapid subsidence coarse detritus is deposited; this phase is usually represented in the stratigraphic record as thick successions of coarse detritus after vertical accommodation is created by subsidence (Castle, 2001).

During the Late Ordovician and Early Silurian the eastern/southeastern Taconic highlands were the dominant sediment source that was eroded and subsequently provided sediment that was deposited in the north-central basin (Faill, 1997). An episodic uplift of the Taconic highlands on the eastern margin created high rates of erosion that supplied sediments to the northwest and west (Folk, 1960; Whisonant, 1977). The early Silurian sedimentation was influenced by tectonism as well as eustatic sea-level fluctuations (Cotter, 1982, 1983; Middleton, 1987; Johnson and McKerrow, 1991; Ross and Ross, 1996).

During the later phase of the orogeny proximal basin infilling occurred as the sediment supply exceeded the accommodation space, due to diminished thrust loading. Further filling 


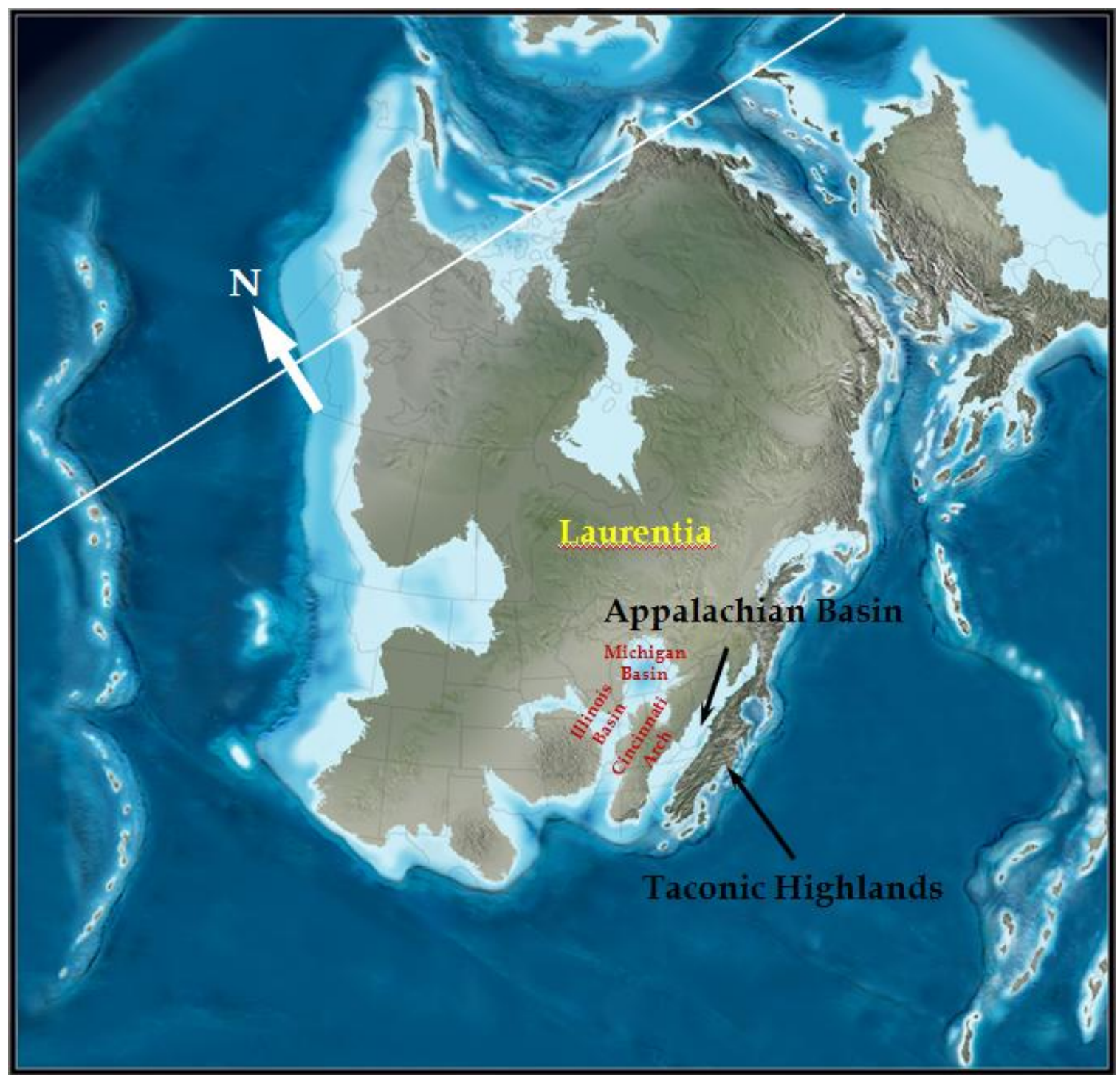

Figure 2: Paleogeography of the Appalachian basin during Silurian time showing major features surrounding the study area. (Modified from Blakey, Ron: http://www2.nau.edu/rcb7/namS430.jpg).

resulted in a cratonward progradation into lateral accommodation space in the distal foreland basin (Castle, 2001b).

Fold-thrust belts like the Appalachian orogen are characterized along their length by alternating structural salients and recesses, which evolved from re-entrants and promontories, respectively (Castle, 2001a, b). The thickness of the Lower Silurian strata is greater in areas of the Pennsylvania salient than in the areas of adjacent recesses, suggesting greater accommodation produced in the salient (Oliver et al., 1967; Woodrow et al., 1988; Castle, 2001). 
This difference in distribution of salients and recesses has created variations in facies distributions: in the Lower Silurian strata where the rate of subsidence was lower than in the salients, the statigraphic succession exhibits deep erosion, regional unconformities, and transgressive infilling (Castle, 2001).

\subsection{Lower Silurian Lithostratigraphy}

Due to the lack of an age-diagnostic fossil record, the age of the Tuscarora Sandstone is inferred from its stratigraphic position between the Upper Ordovician Juniata Formation and Lower Silurian Rose Hill Formation (Cotter, 1982), as well as from correlations to the Medina Group in western New York (Brett et al., 1990). The Tuscarora Sandstone is considered to be Lower Silurian, extending from the base of the Llandoverian to the Llandoverian $\mathrm{C}_{2}-\mathrm{C}_{3}$ stage (Berry and Boucot, 1970).

The Ordovician-Silurian boundary is conventionally placed at the contact of the Silurian Tuscarora Sandstone with the underlying Ordovician Juniata Formation in the subsurface.

Depending on the geographic region of West Virginia, the exact position of this lacuna can be difficult to recognize. This regional unconformity has several names: originally Wheeler (1963)

\begin{tabular}{|c|c|c|c|}
\hline Author (Year) & Unconformity Name & Position & Locality \\
\hline $\begin{array}{l}\text { Wheeler (1963) } \\
\text { Dennison \& Head (1975) } \\
\text { Castle (1998) \& Ryder } \\
\text { (2000) } \\
\text { Diecchio (1985) }\end{array}$ & $\begin{array}{l}\text { Cherokee discontinuity } \\
\text { Taconic discontinuity } \\
\text { Basal unconformity } \\
\text { Basal paraconformity }\end{array}$ & Base of Silurian & $\begin{array}{l}\text { North/Central WV } \\
\text { North/Central WV } \\
\text { Preston County, WV } \\
\\
\text { Eastern WV outcrops }\end{array}$ \\
\hline $\begin{array}{l}\text { Dorsch et al. (1994) } \\
\text { Hettinger (2001) }\end{array}$ & $\begin{array}{l}\text { "Tuscarora" Unconformity } \\
\text { Unconformity } 3\end{array}$ & Intraformational & $\begin{array}{l}\text { SW VA } \\
\text { Western to central WV }\end{array}$ \\
\hline
\end{tabular}

Table 1: Previously interpreted unconformities within the Tuscarora Sandstone

named it the Taconic discontinuity for an unconformity he observed in northern and southern

West Virginia, as well as throughout the Appalachian basin (Table 1). Dennison and Head (1975) later renamed this unconformity the Cherokee unconformity to emphasize that there is no 
relation to the Taconic orogeny. In a regional study, Castle (1998) recognized a basal unconformity in core separating the Tuscarora and Juniata in Preston County, WV. This unconformity may or may not be correlative with the Cherokee discontinuity.

In the Valley and Ridge province of southwest Virginia, Dorsch et al. (1994) uses the term "Tuscarora" unconformity referring to an Ordovician-Silurian unconformable contact between the "lower" Tuscarora and the "upper" Tuscarora. This unconformity is limited to the margins of the Appalachian basin, as the presence of the "lower" Tuscarora diminishes to the northwest and the unconformity is placed between the Tuscarora and Juniata. This unconformity is traced throughout the Valley and Ridge from Virginia to Pennsylvania (Diecchio, 1985; Bambach, 1987; Dennison et al., 1992) and in the eastern panhandle of West Virginia, Folk (1960) subdivided the Tuscarora into lower and upper members. Similar to Dorsch et al. (1994), Hettinger (2001) recognized an unconformity within the Tuscarora caused by a fall in relative base level.

\subsection{Stratigraphic Nomenclature}

In West Virginia, the Tuscarora Sandstone is the accepted nomenclature for all strata occurring above the Juniata Formation and below the Rose Hill Formation. The formation, however, has many stratigraphic equivalents in the Appalachian basin as well as a diverse nomenclature (Figure 3). In order to avoid confusion, a description of the various nomenclatures is presented.

In southern Ohio and northeastern Kentucky the nomenclature of the Silurian Medina Group is as follows, in ascending order: Brassfield Formation, lower Cabot Head Shale, “Clinton"-Tuscarora Sandstone and the upper Cabot Head Shale. In some areas a thin sandstone unit is present at the base of the Brassfield and is known as drillers' "Medina" or "Albion". This 


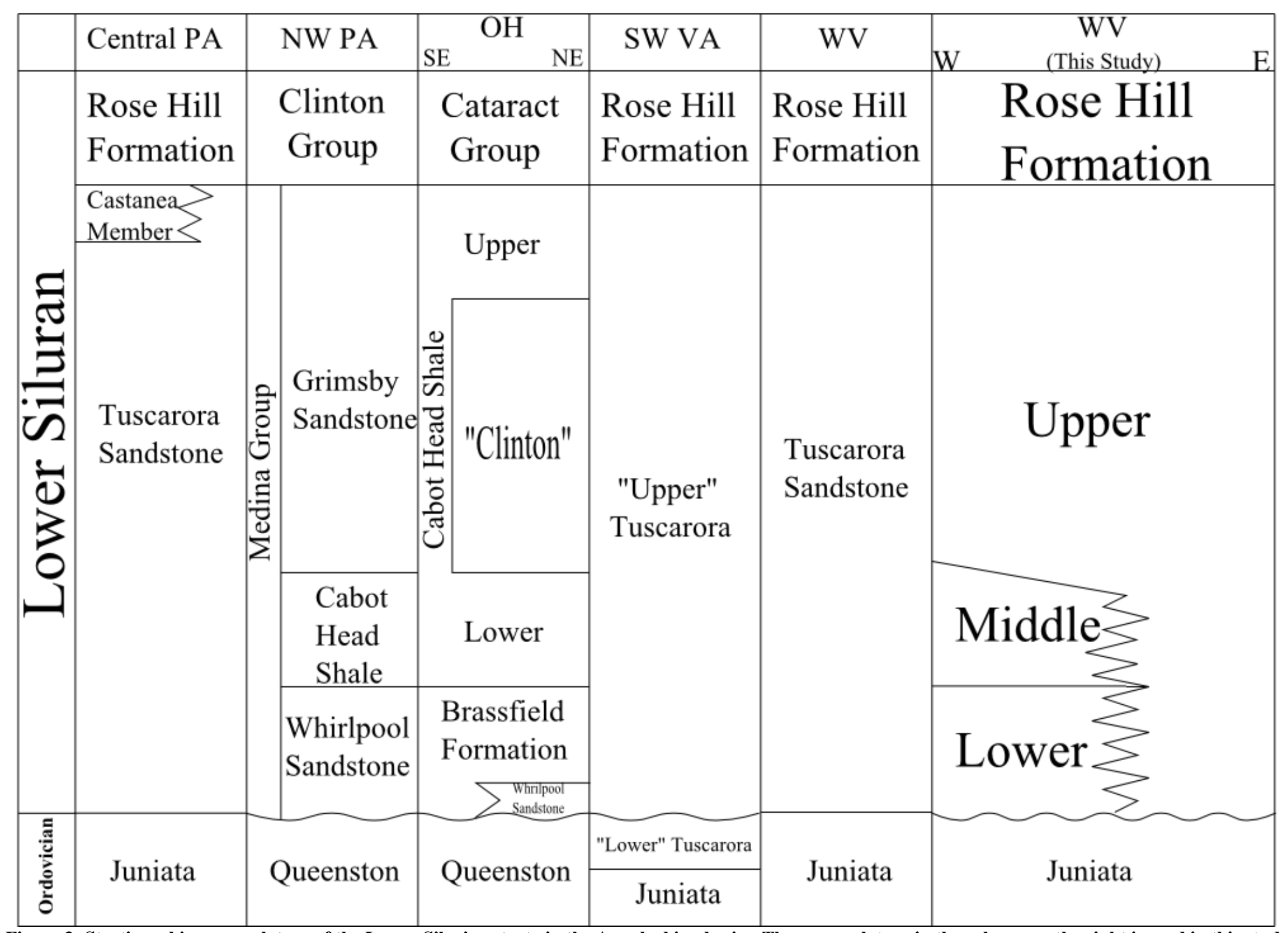

Figure 3: Stratigraphic nomenclature of the Lower Silurian strata in the Appalachian basin. The nomenclature in the column on the right is used in this study (Modified from Castle, 1998). 
unit is stratigraphically equivalent with the Whirlpool Sandstone, a basal Silurian formation recognized in northern and eastern Ohio. Overlying the Medina Group is the Clinton Group.

Overlying the lower Cabot Head Shale in eastern Ohio, drillers have incorrectly termed these oil and gas producing units as the "Clinton" sandstone, which has caused confusion, as it is not the time-equivalent unit to the Clinton Group of Pennsylvania and New York. The "Clinton" is laterally coextensive with the Tuscarora Sandstone in West Virginia and Pennsylvania. However, since the term has become commonplace, it is informally used as the time-equivalent unit of the Tuscarora Sandstone. In northeast Ohio, drillers have further subdivided the "Clinton" into three units: the Stray Clinton, $1^{\text {st }}$ or Red Clinton, and $2^{\text {nd }}$ or White "Clinton". In southern Ohio these are difficult to identify due to a relative thin "Clinton" interval in Vinton, Athens, and Hocking counties (Lukasik, 1988).

In northwestern Pennsylvania, western New York, and northeastern Ohio, coeval rocks are included in the Medina Group (Avary, 1996). These formations in ascending order are: the Whirlpool Sandstone, Cabot Head Shale, and Grimsby Sandstone overlain by the Clinton Group. To the south in central Pennsylvania the Tuscarora Sandstone encompasses the formations from the Medina Group and contains the informal Castanea member.

In other regions such as southwestern and eastern Tennessee, the basal unit is called the Clinch Sandstone (Dennison, 1970). Finally, the equivalent of the Tuscarora in western Virginia is the Massanutten Sandstone and in eastern Pennsylvania and northern New Jersey, the coarsergrained equivalent is named the Shawangunk Formation (Avary, 1996).

For this study the Tuscarora Sandstone in West Virginia will be divided into three informal units, consistent with the nomenclature of adjacent Ohio and northwest Pennsylvania (Figure 3). Where the Brassfield Formation and/or Whirlpool Sandstone are present, this unit is 
referred to as the lower member and the basal sandstone, respectively. Intervals that contain the lower Cabot Head Shale are equivalent to the middle member. Finally, intervals equivalent to the Tuscarora or "Clinton"/Grimsby Sandstone are referred to as the upper member. Overlying this interval are the shale, sandstone and carbonate beds of the Rose Hill Formation.

\subsection{Depositional Environments: Previous Interpretations}

An extensive number of outcrop and subsurface investigations have evaluated the Tuscarora Sandstone to determine its depositional origins and a variety of environments have been interpreted. The consensus is that it was deposited in a near shore, fluvial, and/or littoral environment (Smosna and Patchen, 1978).

Beginning with an early study of Ordovician and Silurian deltaic deposits in central and eastern Pennsylvania, Grabau (1913) interpreted the Tuscarora as being deposited as sand and mud along river flood plains. A lack of fossils, with the exception of trace fossils, and crossbedding thought to be eolian in nature led him to interpret a non-marine environment.

Yeakel (1962) interpreted easterly flowing rivers from the newly raised Taconic highlands across a coastal plain transitioning into deltas in central West Virginia and finally into epicontinental seas in Ohio. In the eastern panhandle of West Virginia, outcrop and petrographic studies by Folk (1960) indicated costal-plain sedimentation in the lower third of the Tuscarora and the upper two-thirds subsequently overlain by high-energy beach deposits. Folk describes a basal red Tuscarora overlain by a lower white Tuscarora and an upper white Tuscarora. The red Tuscarora is interpreted as being deposited in a very flat coastline near the mouths of large rivers, possibly a broad, estuarine muddy flat. He hypothesizes that the red Tuscarora was sourced by rivers carrying iron, thus giving it a red nature. Above this interval in the lower white 
Tuscarora, Folk interpreted a high-energy littoral environment. Finally, the upper white Tuscarora was deposited in a high-energy beach environment.

In northeastern Ohio, Knight (1969) described sediments from core as being deposited on a broad coastal plain that merged with an eastern transition zone, likely deltaic and farther west offshore bars would be present. The source of these sediments likely came from an elevated landmass southeast of the present-day Chesapeake Bay region.

Lower Silurian sands were transported by streams draining uplifted areas to the southeast, an interpretation that is consistent with previous outcrop measurements of paleocurrents in the Tuscarora (Yeakel, 1962). After the sand was moved to the shoreline by fluvial and estuarine channels, it was redistributed by shoreline tidal and wave processes (Castle, 1998).

\subsection{Petroleum Geology of the Tuscarora Sandstone}

The Tuscarora Sandstone is a secondary gas reservoir in what is considered the Lower Silurian regional accumulation (Ryder and Zagorski, 2003). This accumulation also consists of major reservoirs such as the "Clinton" and Medina sandstone units of Ohio and Grimsby Sandstone and Whirlpool Sandstone of the Medina Group in Pennsylvania, New York, and southern Ontario (Ryder and Zagorksi, 2003). The Tuscarora reservoirs consist mainly of quartzarenite, sublitharenite, and litharenite (Wescott, 1982; Bruner, 1983; Murphy, 1984). Murphy's (1984) thin section evaluation suggested that silica was removed from quartz grains via pressure solution and was the main cause of silica cementation. Likely source rocks for the Tuscarora Sandstone are the dark, organic-rich shale units of the Upper Ordovician, including: the Utica Shale, Martinsburg Shale, or the Reedsville Formation that are located several hundred feet below the Tuscarora (Gautier and Varnes, 1993). 
Historically, there have been two phases of exploration: once in the 1960s when major oil and gas companies were heavily invested in exploration and then again in the 1980s, likely driven by high gas prices. Commonly, the Tuscarora was dual completed with the shallower Oriskany Sandstone in order to maximize production. In West Virginia and Pennsylvania over 170 wells have penetrated the Tuscarora; about $70 \%$ of these wells were economically successful (Avary, 1996). Three key Tuscarora fields occur in West Virginia: the Leadmine field in Preston County, the Indian Creek field in Kanawha County, and the Cucumber Creek field in McDowell County (Figure 4). The total reported cumulative production related to the Tuscarora play in West Virginia is approximately 28 billion cubic feet of gas (bcfg) and it should be noted that in some areas, high amounts of carbon dioxide and nitrogen are produced with methane (Figure 4) (Avary, 1996).

The typical trap type for Tuscarora fields in West Virginia is structural in nature, typically anticlines with fracture-enhanced porosity (Avary, 1996). Anticlinal trap examples include the Devil's Elbow field in central Pennsylvania (Harper et al., 1996), Heyn pool in southwestern Pennsylvania, and Leadmine field in northern West Virginia (Ryder and Zagorski, 2003). The Indian Creek field in Kanawha County, West Virginia is an example of a combination-trap field; natural gas is trapped by a porosity change along the plunging nose of the Warfield anticline (Avary, 1996).

Porosity for the Tuscarora is typically low: it ranges from $0.5-1 \%$ in the Devil's Elbow field (Murphy, 1984; Nelson, 1985) to about 7.5-10\% in the Heyn (Avary, 1996) and Indian Creek fields (Bruner, 1983; Avary, 1996). Permeability data is rare in the Tuscarora; however, Bruner (1983) recorded an average of $174 \mathrm{md}$ in the Indian Creek field. Four types of porosity are recognized in the Tuscarora: intergranular, moldic secondary, microporosity, and fracture 


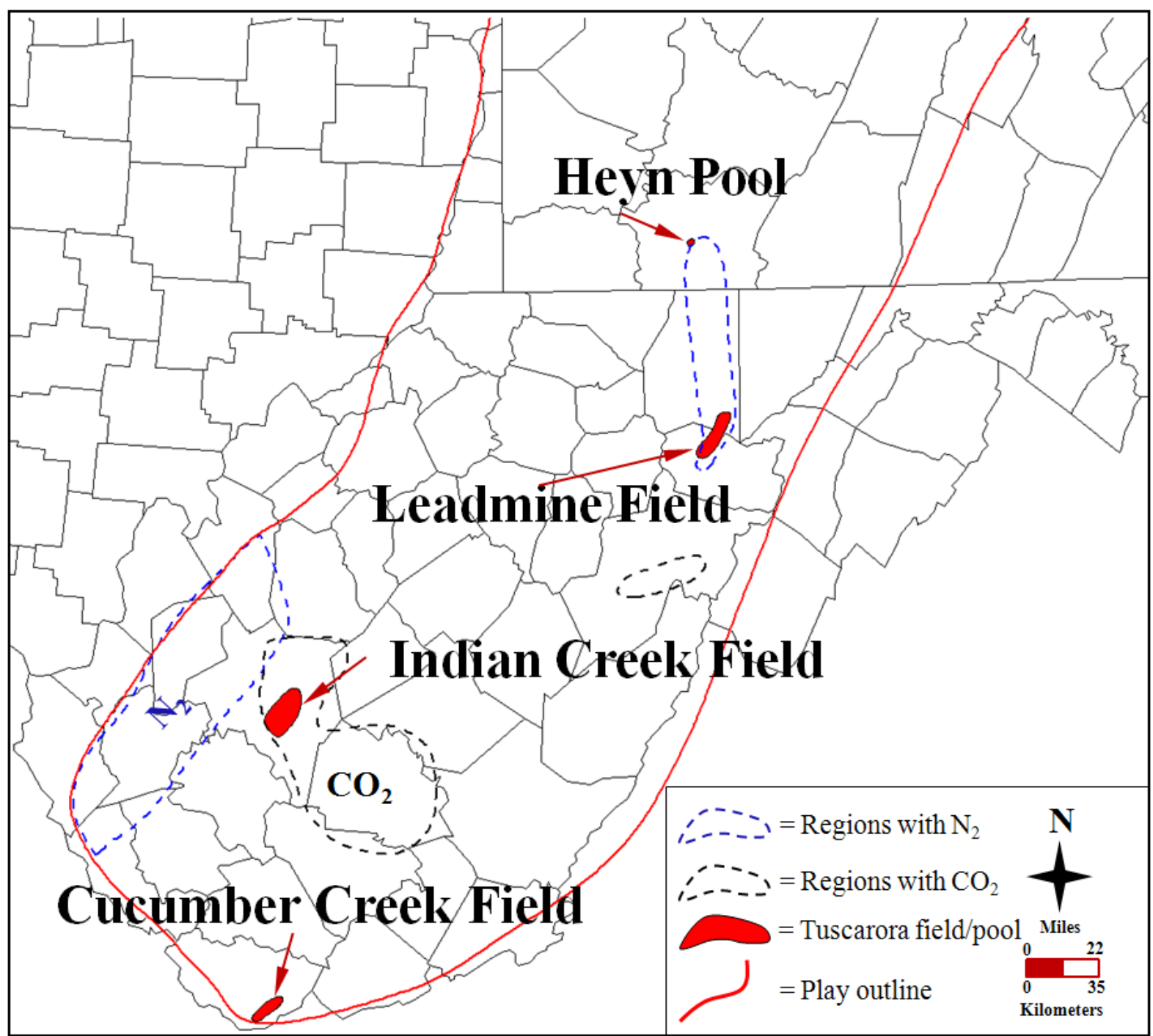

Figure 4: Play outline, fields, pools and location of inert gases in the Tuscarora gas play (Modified from Behling et al., 2008)

porosity, particularly in the Allegheny frontal zone, create the best reservoirs in the sandstone (Wescott, 1982). Porosity in the Tuscarora in the Indian Creek field is a result of incomplete cementation caused by the presence of clay that coat the quartz grains and inhibit the development of secondary porosity and is best developed in the lower and middle portions of the core where grain size is medium to pebbly and coated with clays (Bruner, 1983). 


\section{LITHOSTRATIGRAPHY AND FACIES IDENTIFICATION}

\subsection{Introduction and Methodology}

In order to assess the potential for $\mathrm{CO}_{2}$ geologic storage, an understanding of the regional stratigraphic units is essential. Due to a lack of available core data, the stratigraphic framework

in this study relies on the use of geophysical logs integrated with previous basin-wide subsurface and outcrop interpretations. Well-to-well correlations were completed based on distinct gamma ray $\log$ patterns as well as density and neutron $\operatorname{logs}$ to assist in correlations. To achieve these correlations, various type logs throughout the region were used to map the members of the Tuscarora Sandstone. Previously described cores in the basin were also used to assist with correlations. To accomplish the objectives, the subsequent section is organized as follows: the first section contains core, well cuttings, and outcrop descriptions of the respective member and descriptions are then followed by interpretations of its respective facies.

\subsection{Lower Member}

The lowest stratigraphic interval of the Tuscarora unconformably overlies the Juniata Formation (Wheeler, 1963; Dennison and Head, 1975; Castle 1998; Ryder, 2000; Hettinger, 2001). On wireline logs this unconformity can usually be interpreted from a sharp lower contact at the base of the lower member (Figure 5a and 5c). In some areas this contact is more difficult to define due to the lack of a sharp contact and an increasingly gradational gamma ray log signature (Figure 5b). The gamma response of the lower member varies: sometimes it has a clean gamma ray signature with a bell-shaped to serrated log pattern that tends to fine upwards into the overlying middle member and sometimes the lower member is shale-rich with an indistinct contact with the middle member (Figure 5). Table 2 lists previous descriptions and interpretations of the lower member throughout the Appalachian basin. 


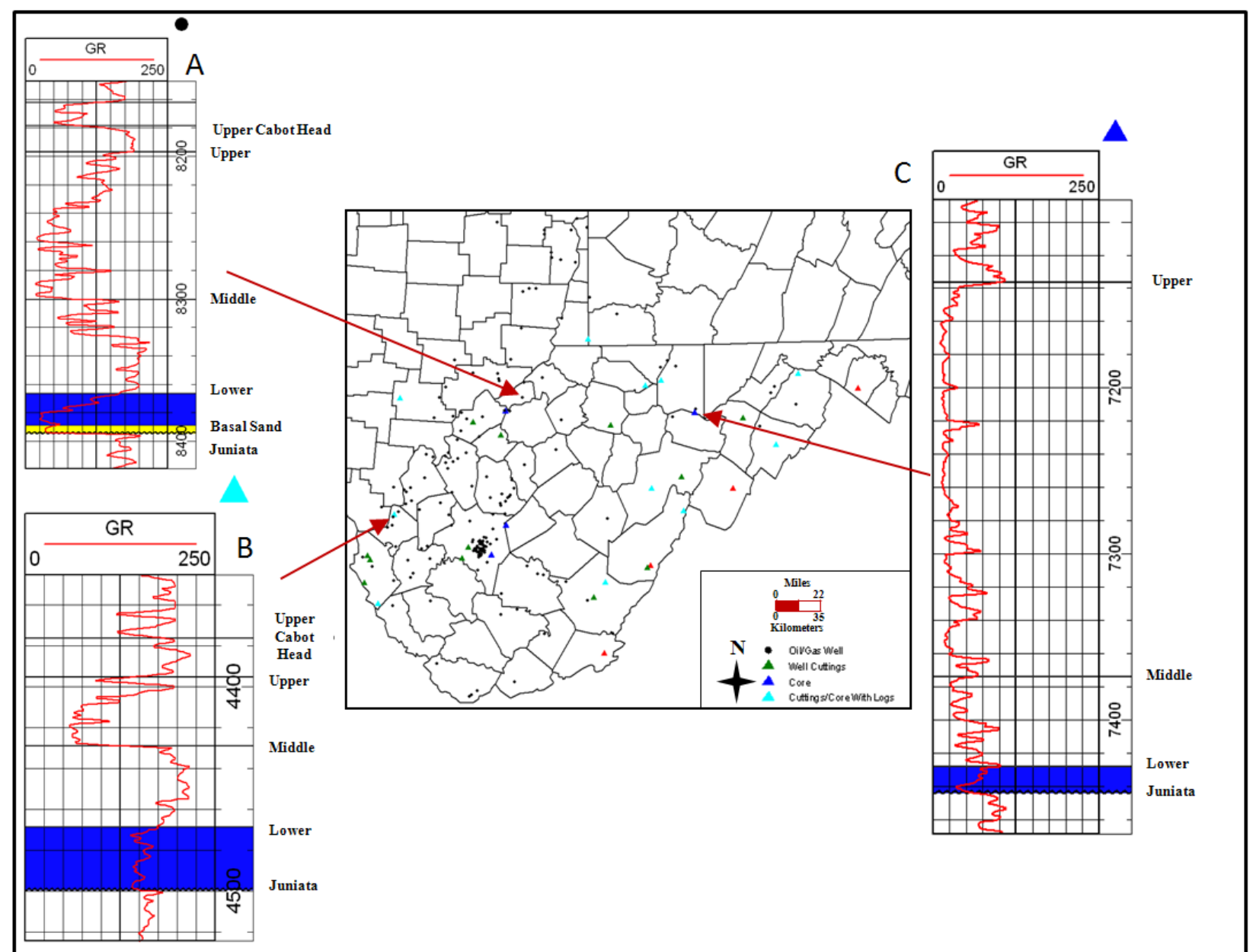

Figure 5: Lower member (highlighted in blue) type logs and locations within the study area. A) Gamma ray log response from Pleasants County (API\# 4707301883) is an example of the bell-shaped curve of the basal sandstone (highlighted in yellow) that occurs locally and is overlain by lower member. B) Gamma response from Cabell County (API\# 4701100537) shows variation in the log signature of the lower member with a gradational contact with the middle member and the absence of a sharp contact with the Juniata Formation. C) Gamma log response from Preston County (API\# 4707700119): this thin interval has a sharp contact with the underlying Juniata Formation and fines upward into the middle member. 


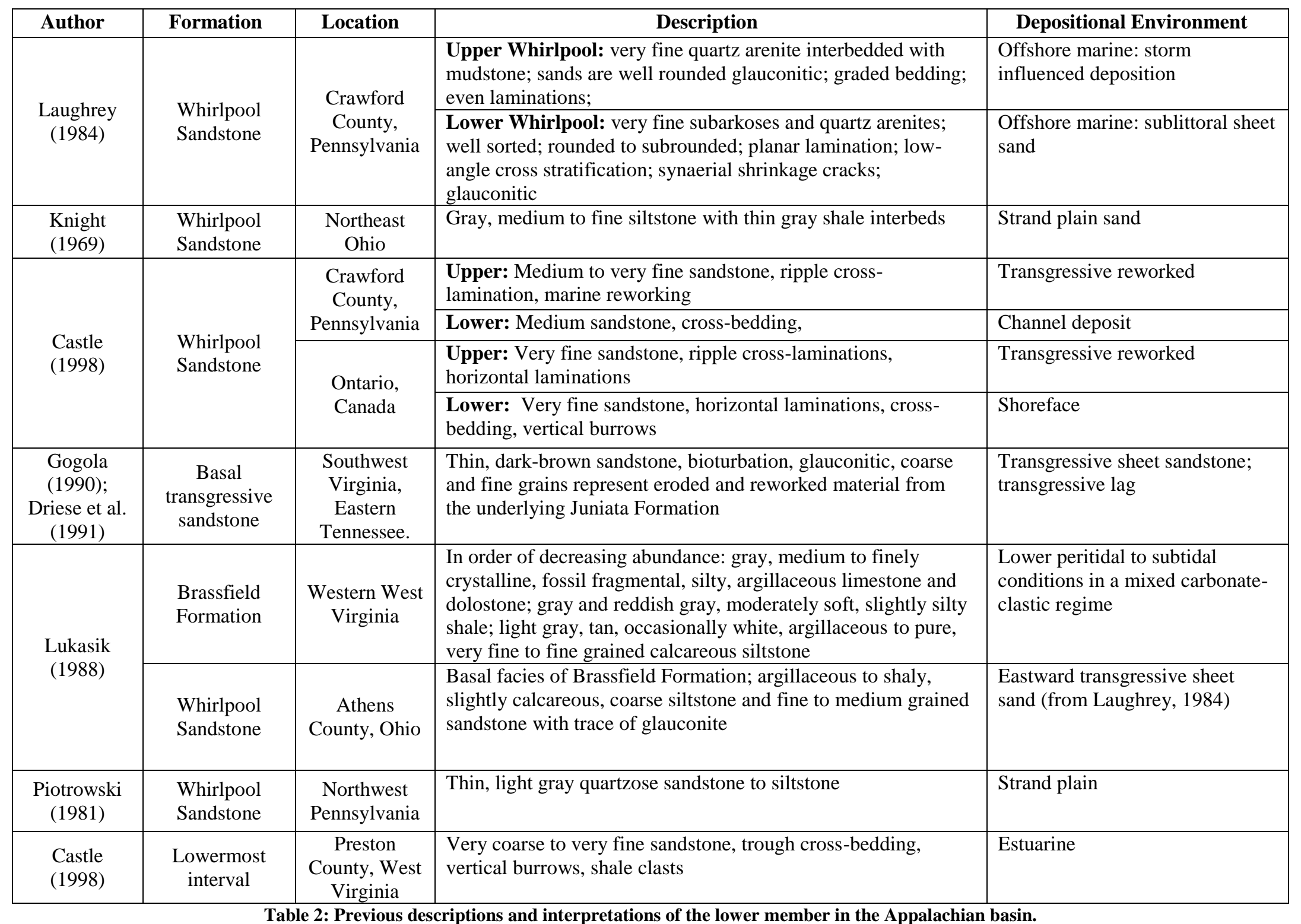

Table 2: Previous descriptions and interpretations of the lower member in the Appalachian basin. 


\section{Eastern West Virginia}

At the base of the lower member in core from Preston County, WV (Columbia Carbon Company well, API\# 4707700119), a sharp contact is interpreted as an unconformity overlain by burrowed, planar and trough cross-bedded, medium- to coarse-grained sandstone (Castle, 1998) (Figures 6 and 7). This unconformity may be the equivalent of the regional Cherokee discontinuity (Castle, 1998). The position of the lower member in Preston County above the interpreted unconformity may be the stratigraphic equivalent of the lower member (Whirlpool Sandstone/Brassfield Formation) that is present in the west-southwest region of the study area. Others have correlated the Medina Sandstone and Whirlpool Sandstone with the lower Tuscarora (Brett et al., 1990; Castle, 1998; Hettinger, 2001). To the southwest in nearby Harrison County (API\# 4703300079) the lower member is 21 feet (6.4 meters) of white, fine- to medium-grained sandstone in well cuttings (Martens, 1945).

In Berkeley County, located in the eastern West Virginia panhandle, Folk (1960) carried out a detailed outcrop study of the Tuscarora Sandstone, subdividing the Tuscarora into three sections; the lowest red Tuscarora interval is described as a grayish-red fine- to medium-grained sandstone with cross-bedding, thin laminations, abundant grayish red clay galls that lie parallel with bedding, and the trace fossil Arthrophycus occurs throughout the interval (See Appendix II for a full description). 


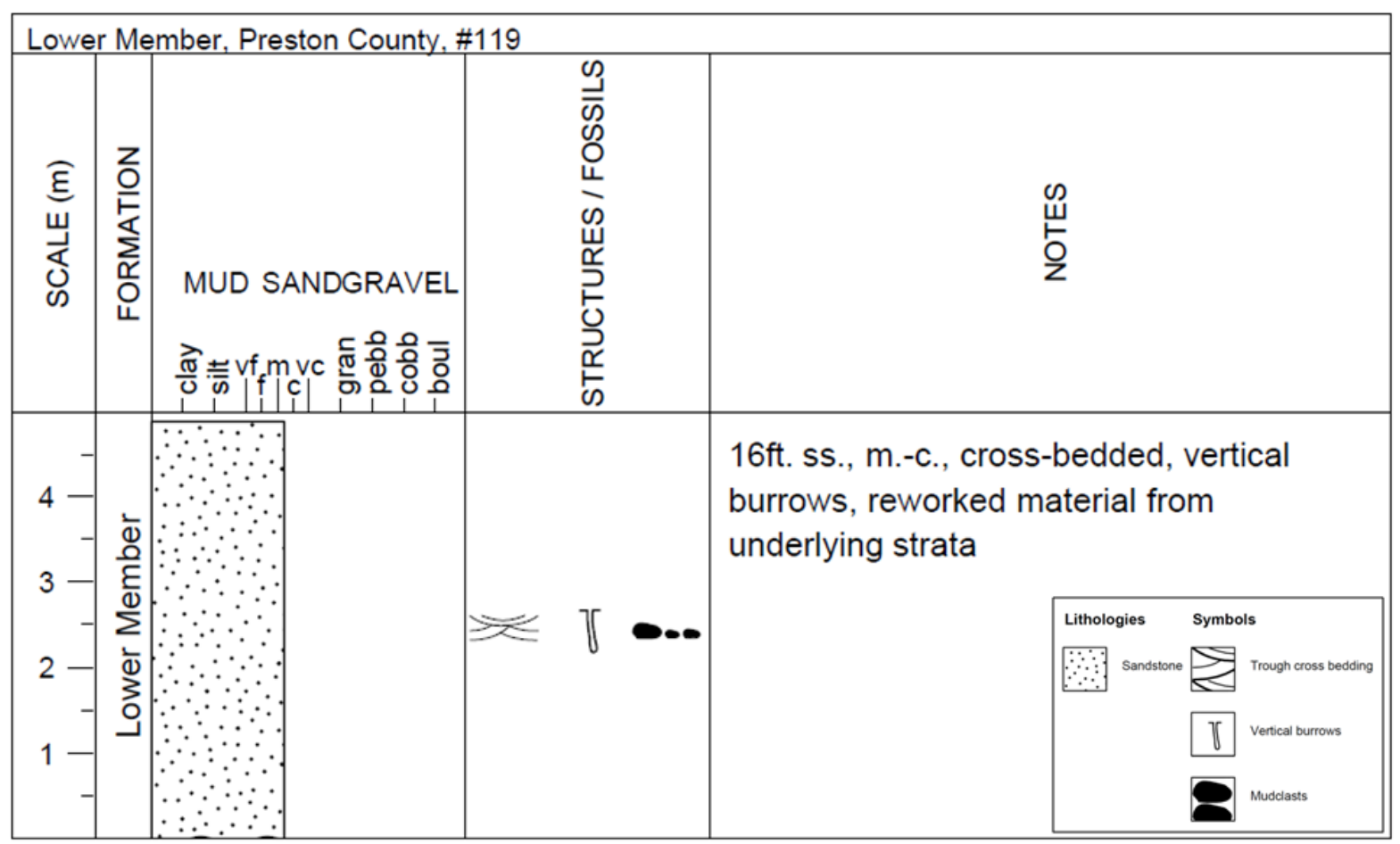

Figure 6: Core description of the lower member in Preston County, WV (API\# 4707700119). This interval contains crossbedded medium to coarse grained sandstone with vertical burrows and shale rip-up clasts $(\mathbf{s s}=\mathbf{s a n d s t o n e} ; \mathbf{m}=\mathbf{m e d i u m}$ grained; $c=$ coarse-grained $)$. (Modified after Castle, 1998).

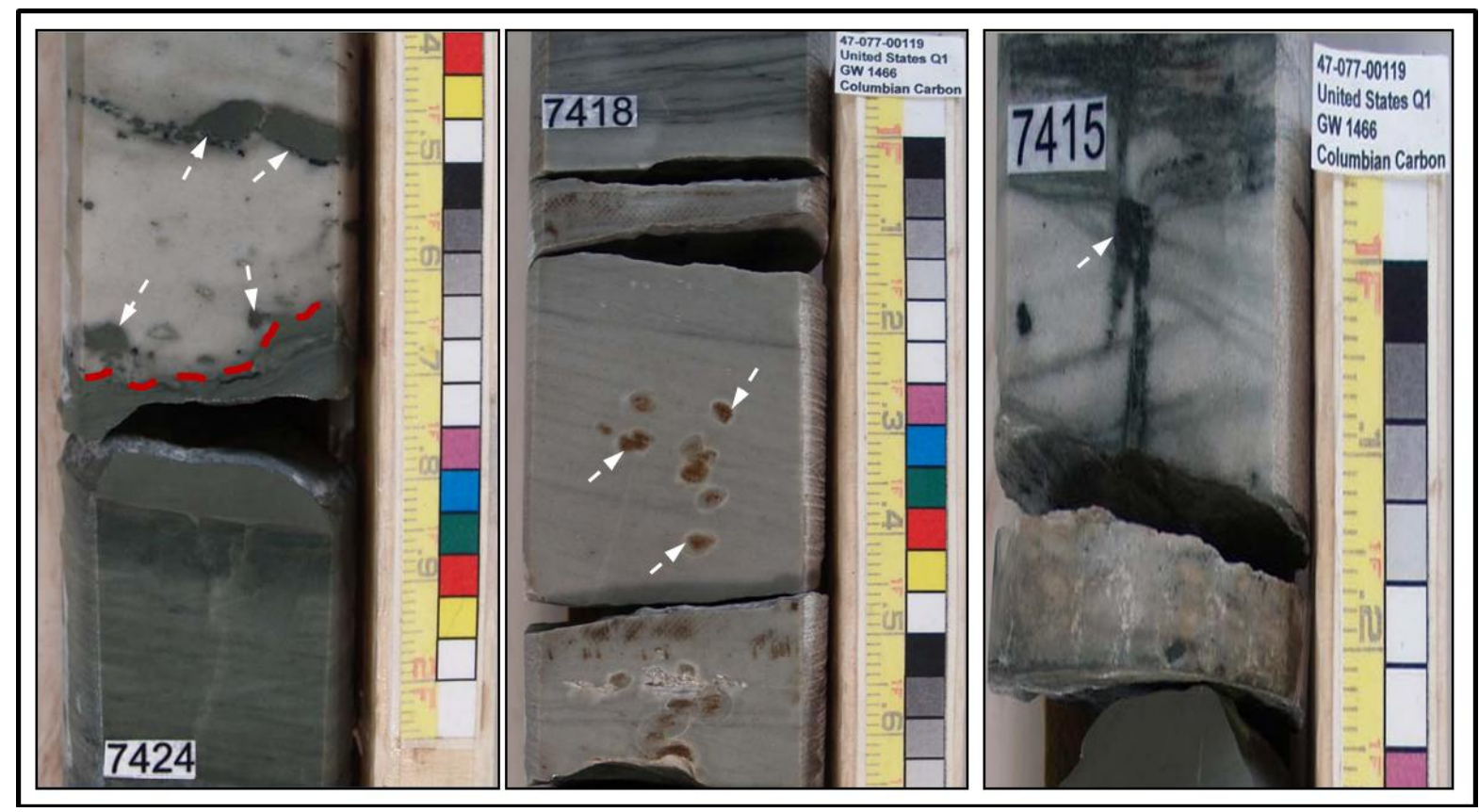

Figure 7: Core photographs from the Columbian Carbon Company well in Preston County, WV (API\# 4707700119). Left: Basal unconformity represented by the red dashed line at the base of the Tuscarora Sandstone at cored depth 7,424 feet $(2,269$ meters). White arrows point to reworked material from underlying strata. Center: Cross-bedded mediumgrained sandstones disrupted by oxidation (horizontal burrows?) at cored depth 7,418 feet (2,261 meters). Right: trough cross-lamination highlighted by organic matter along the bedding planes and interrupted by vertical burrows (Monocraterion?) at 7,415 feet (2,260 meters). 
To the southeast, the lower member may or may not be present. A change in the pattern of the gamma ray log makes it difficult to correlate; however, outcrop studies may provide insight into whether it is present or not. In Pocahontas County, above the unconformable contact of the Juniata Formation and Tuscarora Sandstone, a 1 foot medium- to light-gray basal conglomerate with quartz pebbles is present. Above this unit there is a fining-up sequence to medium- to fine-grained sandstone with low-angle planar cross-beds and the trace fossil Skolithos (Diecchio, 1985). The lower member is difficult to map, is not present throughout the state, and is absent in well logs to the southeast.

\section{Central West Virginia}

The lower member is present in some well logs in central West Virginia, however, drilling commonly stopped before penetrating the lower member and the contact between the Juniata and Tuscarora is commonly misplaced at the contact of the middle and upper member. In central West Virginia where the lower member is logged, there is, again, variation in lithology. Using log overlays and crossplots allows porosity to be derived, as well as obtaining lithological information (Doveton, 1994). By plotting the neutron porosity versus the bulk density log, a quick-look interpretation is provided. A neutron-density crossplot from the Indian Creek field in Kanawha County illustrates a carbonate lithology varying between limestone and dolomite (Figure 8). In adjacent Boone County (API\# 4700500402) the lower member is described as 9 feet (2.7 meters) of fine-grained gray sandstone that is poorly sorted and contains some large rounded grains (Martens, 1945). To the east of this area, the lower member is absent in logs. 


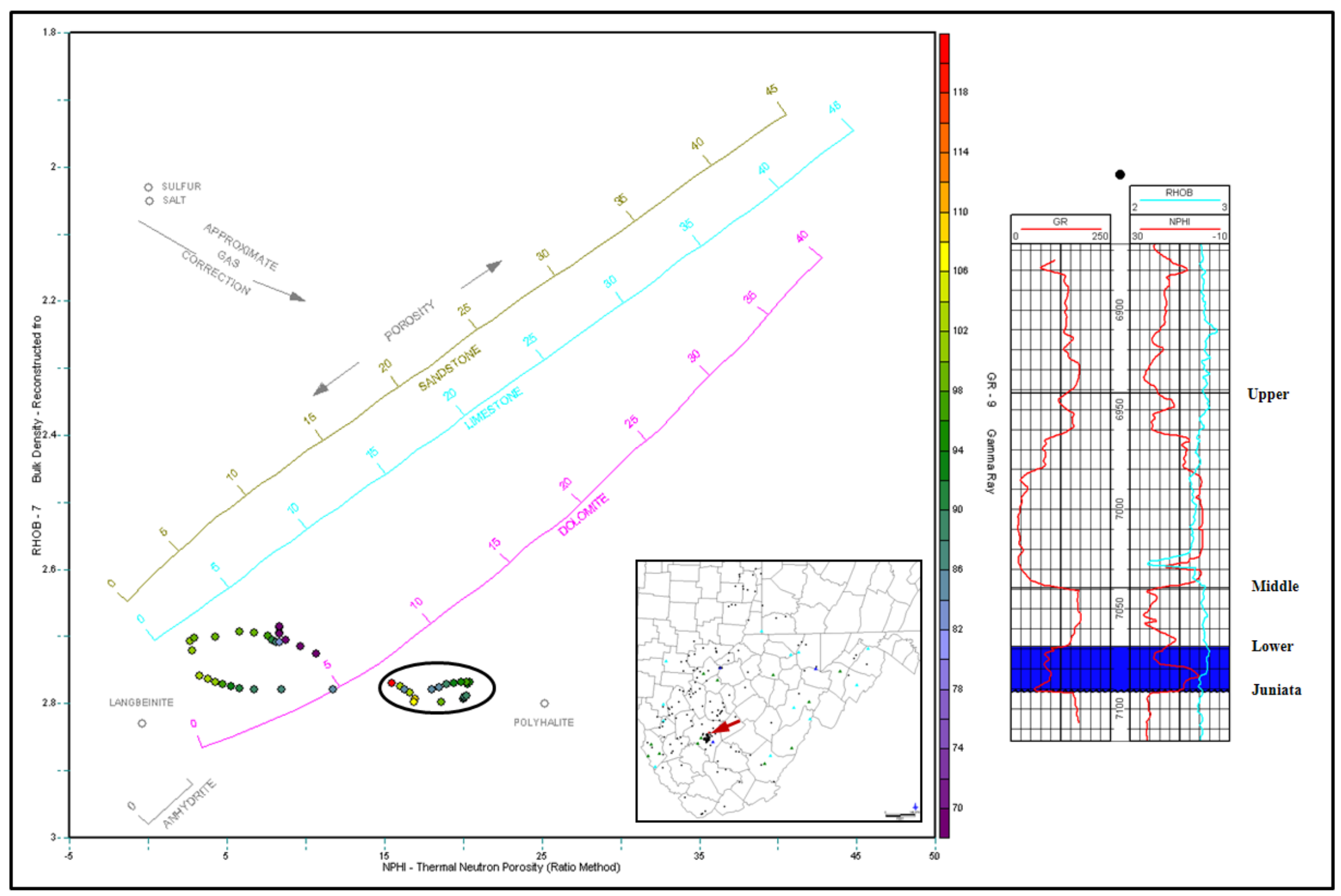

Figure 8: Neutron-density crossplot of the lower member in the Indian Creek field, Kanawha County (API\# 4703903351). The crossplot indicates a limestone with clay beds. Shale beds have a tendency to pull the crossplot to the lower right (circled). 


\section{Western West Virginia}

Sample descriptions of the lower member from previous studies in western West Virginia and southeast Ohio have been described (Lukasik, 1988). Overall, in western West Virginia there is from most to least abundant: a variety of lithologies including gray, medium to finely crystalline fossil fragmental, silty, argillaceous limestone and dolostone; gray and reddish gray moderately soft, slightly silty shale; and light gray, tan, occasionally white, argillaceous to pure, very fine to fine grained, calcareous siltstone (Lukasik, 1988). For example, based on well cuttings from Cabell County, (API\# 4701100537) the lower member is a light tan to white, finegrained limestone (Lukasik, 1988). Additionally, very light gray, very fine- to fine-grained siltstone beds are present (See Appendix II for full descriptions). Below the lower member, a sharp change in color and lithology to red, silty, micaceous shale indicates penetration of the Juniata Formation (Lukasik, 1988). The sharp contact is interpreted to be an unconformable contact. This unconformity is also recognized in the Power Oil Company core from Wood County, (API\#4710700351) which is described as 1 foot (0.3 meters) of dark gray shale with thin laminations and a reworked zone at the base containing material from the underlying Juniata Formation (Bayles et al., 1956). The corresponding neutron-density crossplot for the lower member interval from Cabell County indicates low-porosity and an argillaceous calcite lithology (Figure 9). 


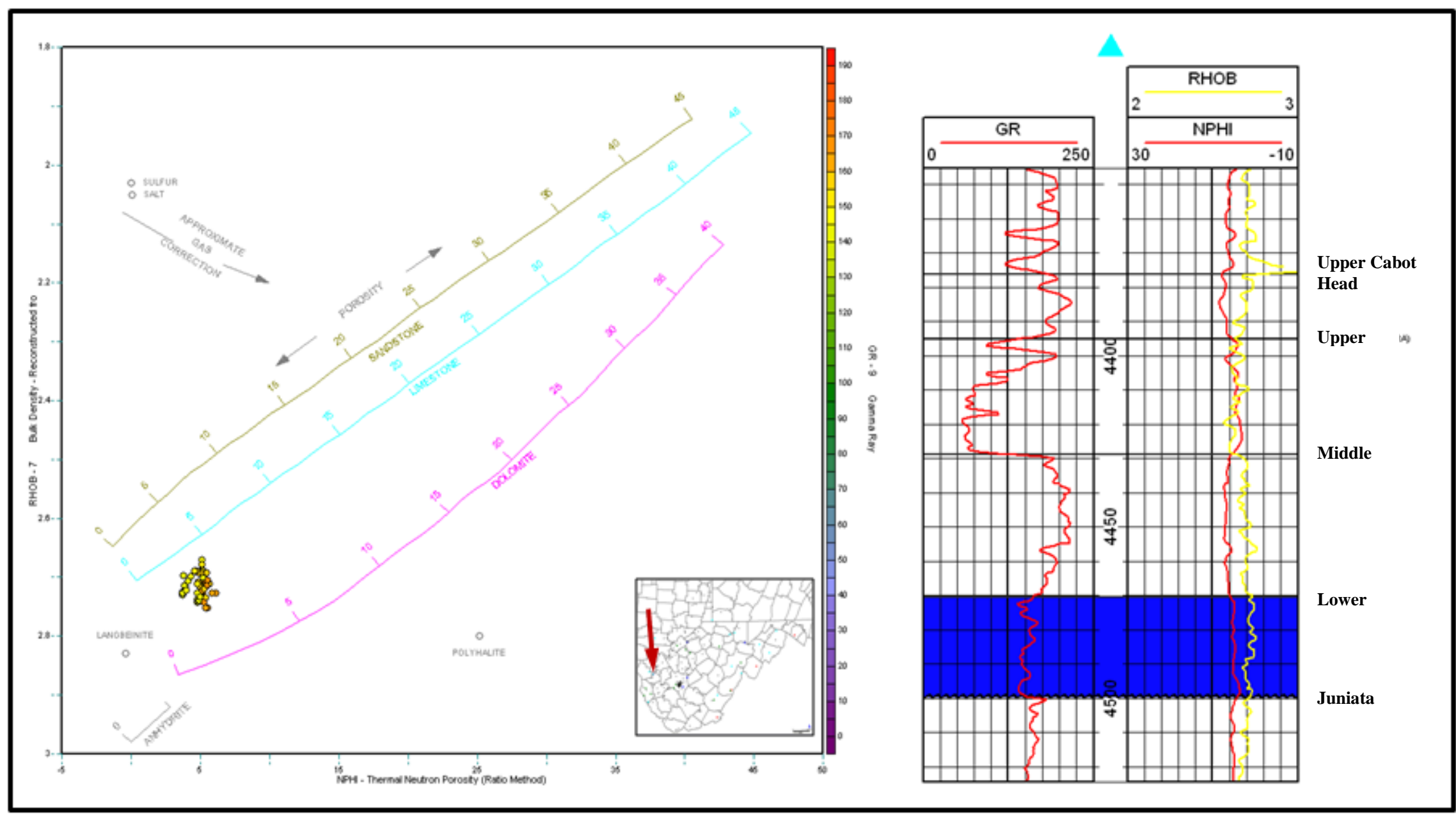

Figure 9: Neutron-density crossplot of the lower member of the Tuscarora Sandstone (API\# 4701100537) from Cabell County, West Virginia. Crossplot shows this lowporosity interval is argillaceous and calcitic, consistent with well cutting descriptions. Note the absence of the sharp unconformable contact at the base of the lower member. 
In some localities, the basal sandstone (Whirlpool Sandstone of Ohio) underlies a carbonate interval. Lukasik (1988) described this subunit from well-cuttings in southeast Ohio as an argillaceous to shaly, slightly calcareous, coarse siltstone and fine- to medium-grained sandstone with a trace of glauconite. This subunit of the lower member typically occurs in the central west to northwest region of the study area, however, a sandy interval does appear in other counties. Well cuttings from Wood County, West Virginia (API\# 4710700099) containing this basal member are described as 6 feet ( 2 meters) of white, very fine-grained sandstone with a large amount of shale (Martens, 1945). Well cuttings from Boone County, WV (API\# 47000500402) are described as a lower 9 foot (2.7 meters) interval containing gray, poorly sorted, fine-grained sandstone that also contains some large rounded grains (Martens, 1945). The neutron-density crossplot of the lower member in Jackson County, located in westcentral West Virginia, shows a mixed lithology between quartz and carbonate (Figure 10). The data points that plot on the sand line are the basal sand-rich component overlain by the more argillaceous and carbonate-rich lower member. 


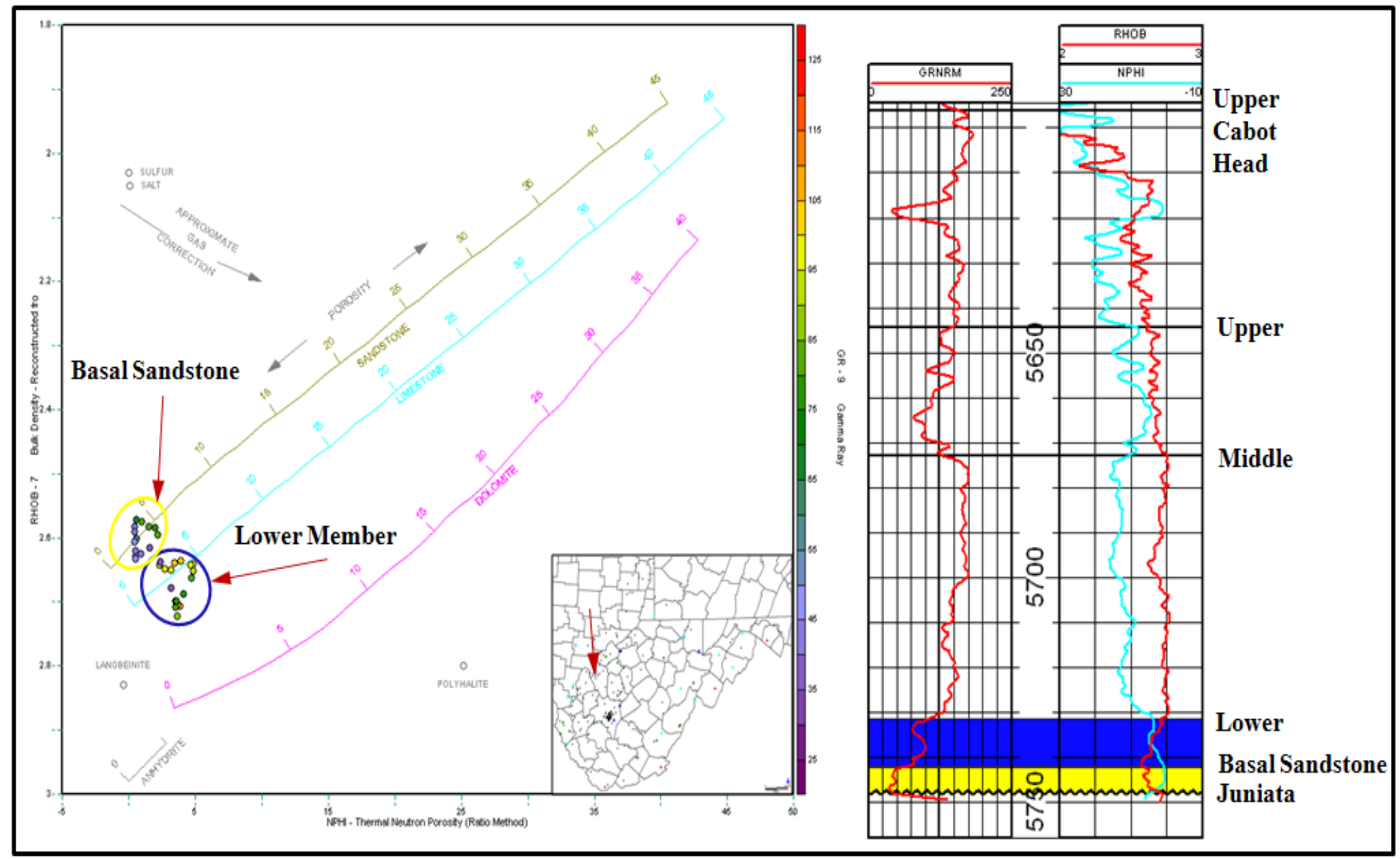

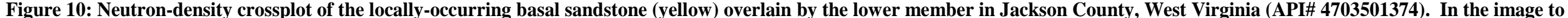

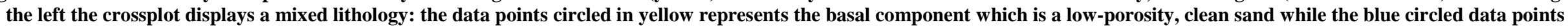
represent the lower member, interpreted as an argillaceous carbonate. Note neutron-density crossover in right track, indicating the presence of gas. 


\subsection{Lower Member Facies Interpretation}

\section{Eastern West Virginia}

Several interpretations have been suggested for the lower member of the Tuscarora Sandstone depending on where it is geographically (Table 2). Likewise, several interpretations are made for the lower member in West Virginia in this study. In eastern West Virginia the sharp contact observed at the base of this interval is interpreted as an unconformity in this study (Figure 7). In Preston County, Castle (1998) interpreted the lower member to be an estuarine environment due to the presence of burrowed, planar and trough cross-bedded, medium- to coarse-grained sandstone. This interpretation is consistent with Folk's (1960) interpretation of the red Tuscarora, which he interpreted as being deposited on the "borderline between a continental and nearshore marine environment". Folk (1960) concludes that this red Tuscarora may have been deposited as a broad estuarine muddy sand flat. Likewise, in south central Pennsylvania Cotter (1983) interpreted a basal pink transitional lithofacies consisting of crosslaminated sandstone and thin red shale to represent an estuary. This study interprets this lower member in northeast West Virginia to represent a tidal-influenced fluvial sandstone.

\section{Western West Virginia}

In southwest West Virginia, the well cuttings from Wayne and Cabell counties indicate a limestone and dolomitic siltstone with an overall lack of clastics, indicating a shallow marine depositional environment with limited clastic input (Figure 5b; Figure 9). To the west in southeast Ohio, the lower member or Brassfield Limestone is interpreted as an extensive, transgressive basal carbonate sheet (Lukasik, 1988). In northwestern West Virginia, the well 
cuttings reveal shale, sandstone, and siltstone as well as fossils. This likely was deposited in a clastic offshore environment.

The well cuttings of the lower member in west-central West Virginia contain more clastics than the lower member in the southwest region. Using wireline logs, cross-sections can be constructed and used to view the subsurface facies geometries and relationships. Correlation of the lower member in the central and western region of the study area reveal that the lower member is a clean sandstone that may have been deposited as a braided fluvial sandstone in shallow incised valleys (Figure 10). These incised valleys form in two phases: the first phase involves erosion of the underlying in response to a fall in sea-level and the second phase involves backfilling that occurs in response to a relative rise in sea-level (Van Wagoner et al., 1990). Others have also interpreted the Whirlpool Sandstone as channel deposition in incised valleys (Ryder et al., 1996; Castle, 1998). The argillaceous carbonate beds of the lower member that overlie the basal sandstone may be backfilling of the shallow incised valleys during the ensuing rise in sea-level, deposited in an estuarine environment. To the east, the localized, basal conglomerate in outcrop in Pocahontas County may be the upper reaches of the incised valley system, possibly indicating that fluvial channels flowing from the east incised into the underlying shelf mudstones of the Juniata Formation during a fall in sea-level. A similar depositional origin for the Whirlpool Sandstone in Lake Erie has been interpreted. The Whirlpool Sandstone is subdivided into two units: a fluvial unit and an estuarine to marine transitional unit. The lowermost unit was a sandy braided fluvial system flowing towards the northwest and confined to shallow valleys, overlain by an estuarine to shoreface complex (Johnson, 1999). The carbonates present formed on carbonate platforms to the west of the Lake Erie region. 


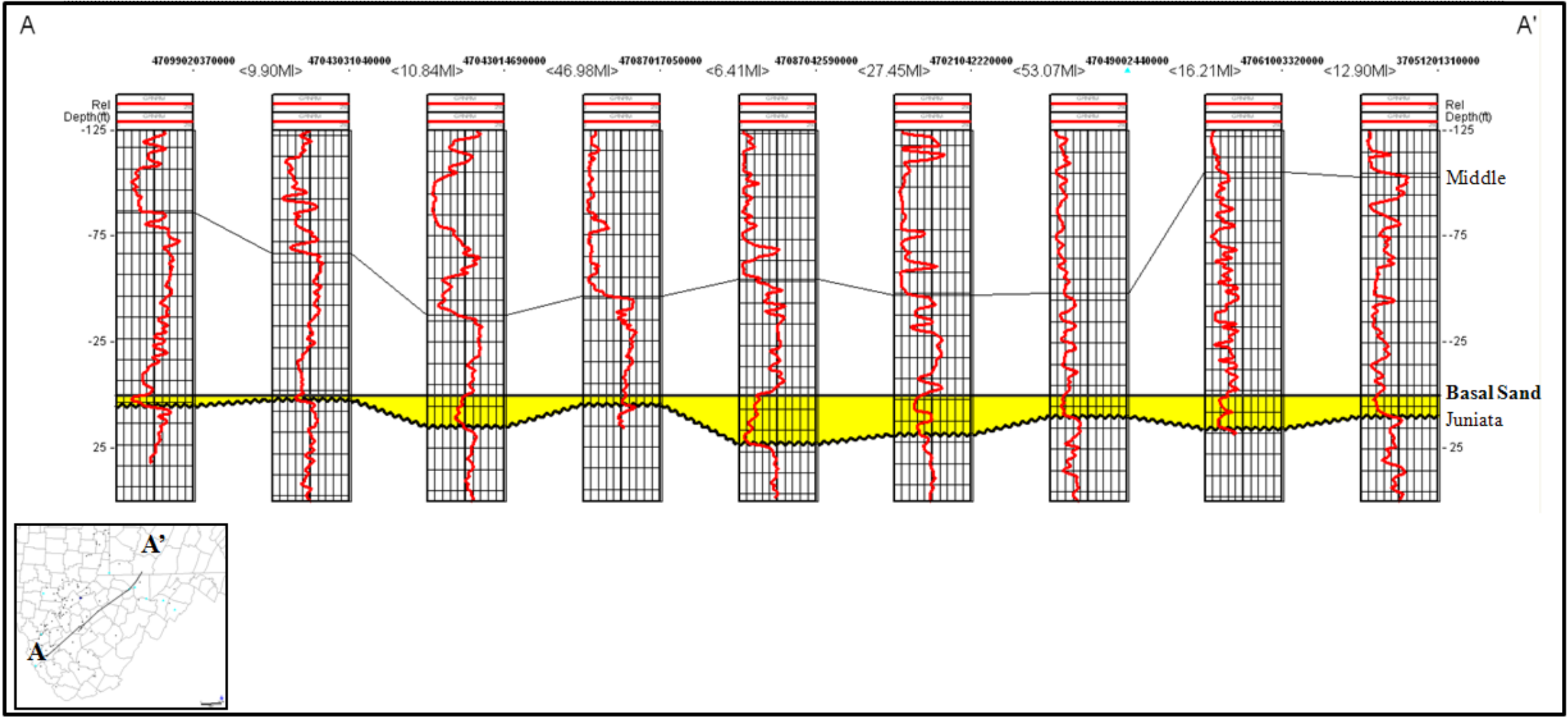

Figure 11: Southwest to northeast cross-section of the basal sandstone (yellow). The thicker intervals are interpreted to be shallow valleys created by fluvial incision during a fall in sea-level. More detailed cross-sections and maps are presented in the next chapter. Basal sandstone used as a datum. 
The deposition of the lower member is explained by a fall in sea level during isostatic rebound in the latest Ordovician. During the hiatus, erosion distributed clastic materials to the northwest. During the subsequent sea-level rise, these deposits were reworked and overlain by fine-grained clastics or carbonate deposits (Dorsch et al., 1994). The rise in sea level is related to a combination of tectonism and eustasy. In southern Ontario and New York, Cheel and Middleton (1993) interpreted pre-transgression subsidence attributed to the emplacement of a tectonic load in the Appalachians to east to contribute to sea level rise. To the south the origin of the lower member is interpreted to be a result of Hirnantian glacio-eustasy (Dorsch and Driese, 1995)

\section{Lower Member Isopach and Paleoenvironment Map}

To calculate the lower member, only wells that penetrated through to the Juniata were used. Using 108 wells, the lower member thickness was calculated from the top of basal sandstone to the top of the Juniata Formation (Figure 12). The thickness of the lower member ranges from $0-22$ feet $(0-6.71$ meters $)(4.8$ meters $)$. There are thickness trends that appear to be oriented in a northwest-southeast direction. These thickness trends are interpreted to be braided fluvial channels occurring in shallow incised valleys, sourced from the southeastern Taconic highlands. The unit appears to thin to the northwest in southeast Pennsylvania, and it is not present in the southeastern region of the study area.

During isostatic rebound, detritus was shed and transported to the northwest from a paleoslope to the southwest (Dorsch and Driese, 1995) (Figure 12). Accommodation was created from a rise in sea-level during the mid-Hirnatian (Brenchley, 1989; Johnson, Kaljo, and Rong, 1991) as well as subsidence related to thrusting (Cheel and Middleton, 1993). 


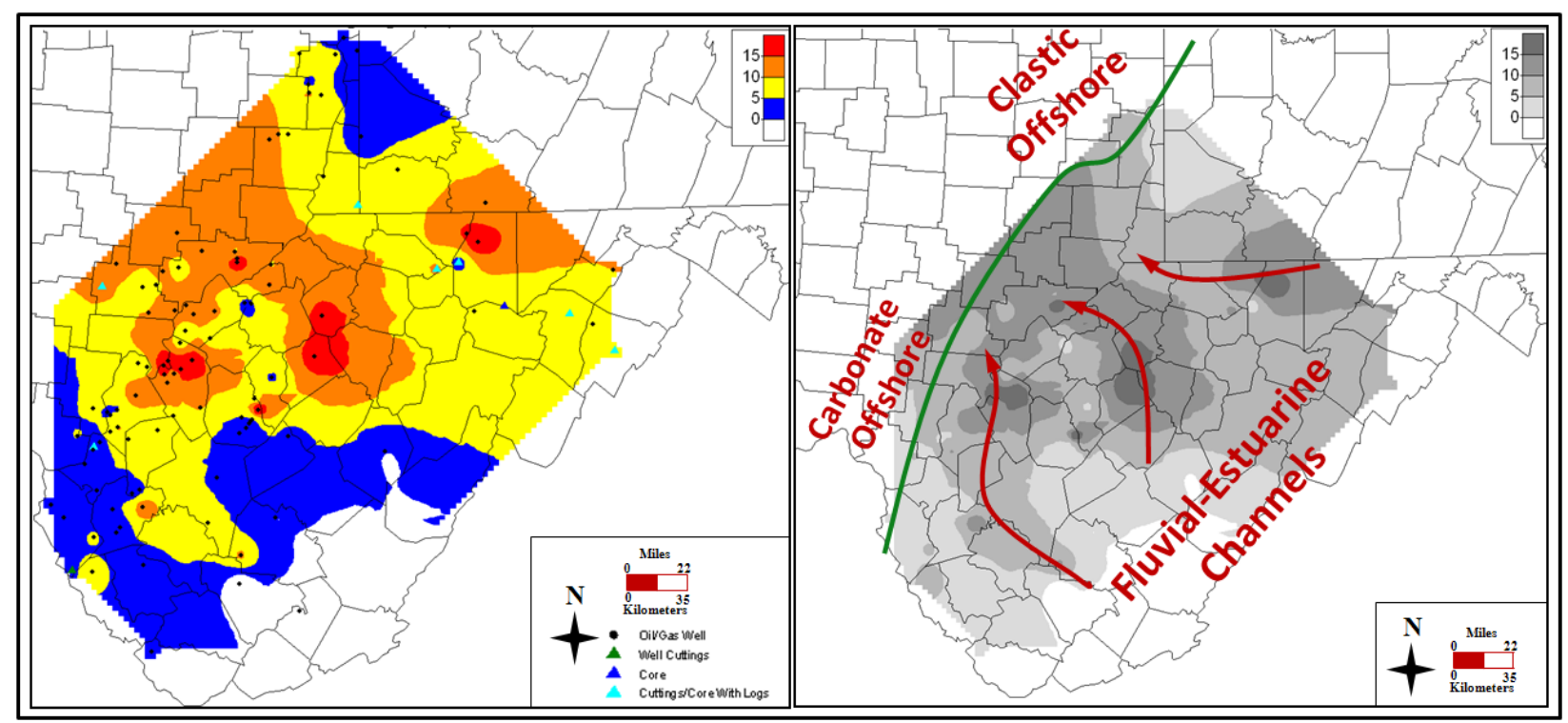

Figure 12: Thickness map of the basal sand calculated from 108 wells (Left). The thickness trends that are oriented to the northwest may be braided fluvial channels (Right). It is interpreted that these channels were sourced from the highlands in the southeast and flowed to the northwest.

\subsection{Middle Member Description}

Overlying the lower member is the middle member of the Tuscarora Sandstone (Cabot Head Shale in Ohio and northwest Pennsylvania). Picking the contact between the lower member and middle member can be difficult due to its gradational nature; however, the addition of well cuttings is useful for identifying the contact between the members. On gamma ray logs, the contact between the lower and middle member is placed at the top of a fining upward sequence in the lower member (Figure 13). API values for the middle member typically exceed 200 API. A list of previous interpretations of the middle member in the basin is found in Table

3. 


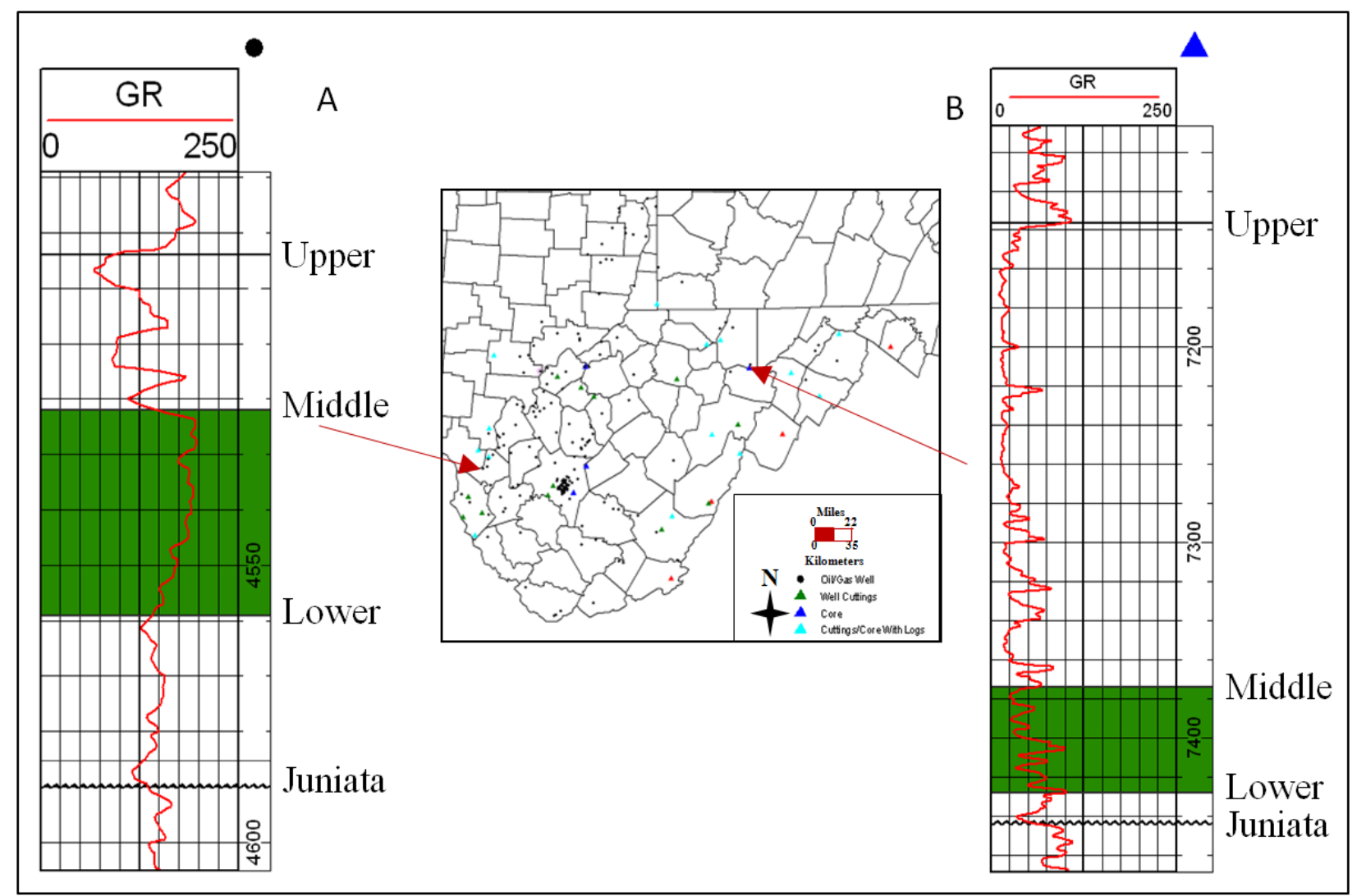

Figure 13: Type log of middle member (highlighted in green) in a) Cabell County, WV (API\# 4701100532) and b) Preston County, WV (API\# 4707700119). In the west the gamma ray log response typically exceeds 200 API and displays a fining upward sequence. In the northeast, the log response is differs from the response found in western study area gamma logs and is usually serrated. 


\begin{tabular}{|c|c|c|c|c|}
\hline Author & Formation & Location & Description & Depositional Environment \\
\hline $\begin{array}{l}\text { Laughrey } \\
\text { (1984) }\end{array}$ & $\begin{array}{l}\text { Cabot Head } \\
\quad \text { Shale }\end{array}$ & $\begin{array}{l}\text { Crawford } \\
\text { County, } \\
\text { Pennsylvania }\end{array}$ & $\begin{array}{l}\text { Unit 1: Argillaceous siltstone and interbedded mudstone; } \\
\text { extensively burrowed to bioturbated; indistinct wavy and } \\
\text { irregular laminations } \\
\text { Unit 2: Very fine to fine subarkose and sublitharenite; } \\
\text { glauconitic; hummocky cross-laminae, near-horizontal fine } \\
\text { laminae, minor burrows } \\
\text { Unit 3: very fine subarkose, mudstone laminae, ripple bedding, } \\
\text { abundant Chondrites } \\
\text { Unit 4: Interlaminated very fine to coarse silt-sized arkose } \\
\text { wacke; ripple lamination; flasers and lenticular laminae, } \\
\text { abundant Chondrites } \\
\text { Unit 5: Sandy and silty, illitic-chloritic mudstone, indistinct } \\
\text { horizontal laminations and bedding, strongly bioturbated; very } \\
\text { fossiliferous (gastropods; crinoids; corals; Chondrites) }\end{array}$ & $\begin{array}{l}\text { Unit 1: Offshore marine: storm } \\
\text { influenced } \\
\text { Units 2-5: Shallow marine }\end{array}$ \\
\hline $\begin{array}{l}\text { Knight } \\
(1969) \\
\end{array}$ & $\begin{array}{l}\text { Cabot Head } \\
\text { Shale }\end{array}$ & $\begin{array}{l}\text { Northeast } \\
\text { Ohio }\end{array}$ & $\begin{array}{l}\text { Lower: Dark green to black shale, lenticular, medium- to fine } \\
\text { quartz siltstone laminations; siltstone increases upward }\end{array}$ & Prodelta/Delta front \\
\hline \multirow{3}{*}{ Castle (1998) } & $\begin{array}{l}\text { Cabot Head } \\
\text { Shale }\end{array}$ & $\begin{array}{l}\text { Crawford } \\
\text { County, } \\
\text { Pennsylvania }\end{array}$ & $\begin{array}{l}\text { Thick intervals of medium gray shale and thin siltstone } \\
\text { laminations; upper and lower contacts are gradational, although } \\
\text { locally sharp }\end{array}$ & Marine shelf \\
\hline & $\begin{array}{l}\text { Power Glen } \\
\text { Shale }\end{array}$ & $\begin{array}{l}\text { Ontario, } \\
\text { Canada }\end{array}$ & See description above & Marine shelf \\
\hline & Marine Interval & $\begin{array}{l}\text { Preston } \\
\text { County, West } \\
\text { Virginia }\end{array}$ & $\begin{array}{l}\text { Medium sandstone, planar and trough cross-bedding, vertical } \\
\text { burrows }\end{array}$ & $\begin{array}{l}\text { Marine (may be correlative with } \\
\text { Cabot Head-Power Glen of } \\
\text { PA/NY/OH }\end{array}$ \\
\hline $\begin{array}{c}\text { Lukasik } \\
(1988)\end{array}$ & $\begin{array}{l}\text { Cabot Head } \\
\text { Shale }\end{array}$ & $\begin{array}{l}\text { Southeast } \\
\text { Ohio }\end{array}$ & $\begin{array}{l}\text { Greenish gray to reddish gray, soft, moderately fissile, } \\
\text { unfossiliferous, dolomitic shale; slightly silty, pyritic, and } \\
\text { glauconitic; locally thin lenses of limestone, dolomite, and } \\
\text { siltstone account for } 20 \% \text { of the unit }\end{array}$ & Prodelta \\
\hline
\end{tabular}

Table 3: Selected list of previously descriptions and interpreted depositional environments of the middle member in the Appalachian basin. 


\section{Eastern West Virginia}

In core from Preston County the interval above the lower member is described as a shaley, medium-grained sandstone, with trough cross-bedding, shale rip-up clasts and vertical burrows (Castle, 1998) (Figures 14 \& 15). Occasional bidirectional cross-bedding occurs (Castle, 1998) (Figure 15). The log response in eastern West Virginia varies, but typically shows a serrated pattern, indicative of interbedded sandstone and shale (i.e. heterolithic sandstone). To the southwest in adjacent Harrison County (API\# 4703300079), the middle member becomes increasingly shale-rich; well cuttings are described as 24 feet (7.3 meters) of dark-gray shale that is thinly bedded with fine-grained, light-gray sandstone (Martens, 1945). Like the lower member, this middle member is absent in the southeastern region of the state.

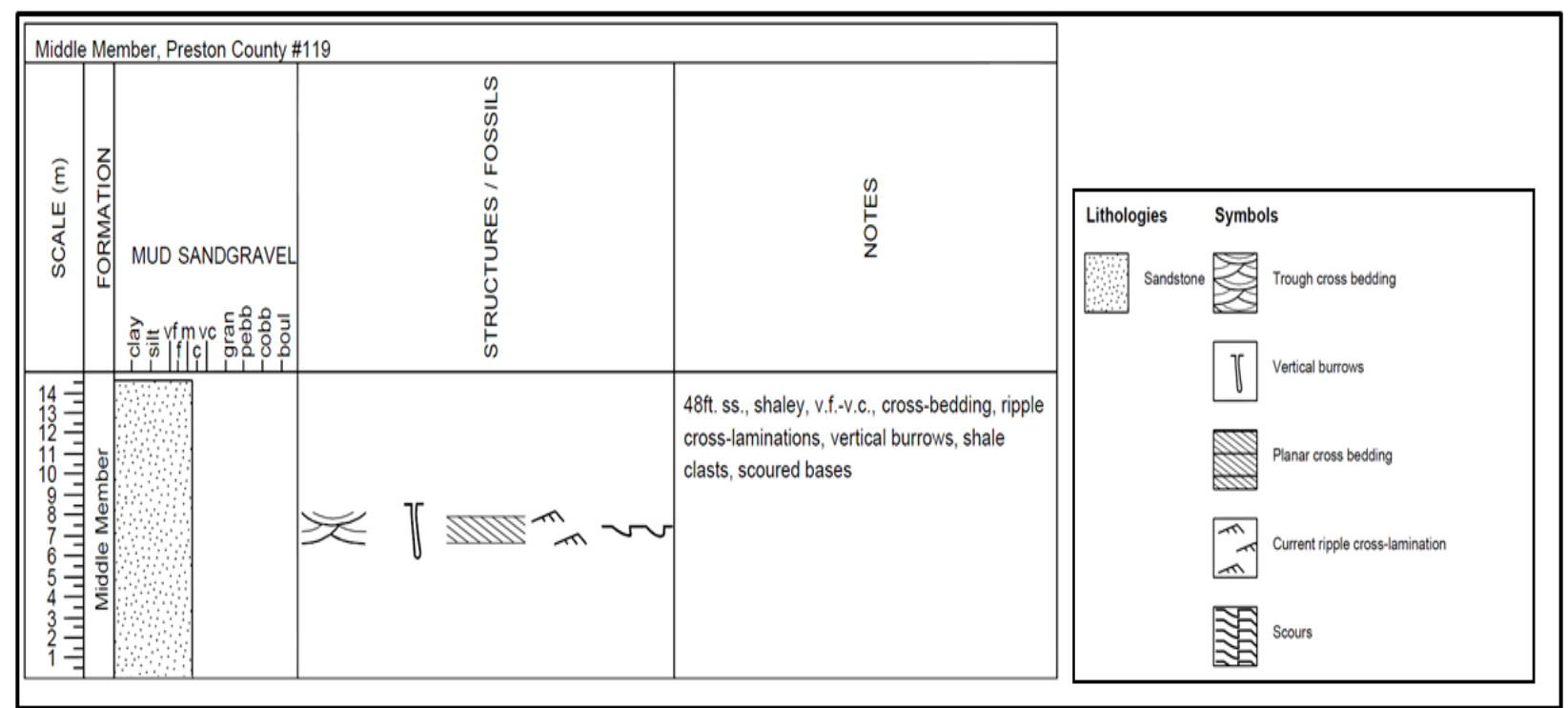

Figure 14: Core description of the middle member in Preston County, WV (API\# 4707700119). Physical and biological features include: a shaley, very fine to medium-grained sandstone with cross-bedding and vertical burrows (ss = sandstone; $v f=$ very fine; $v c=$ very coarse $; \mathbf{m}=$ medium $)$. 


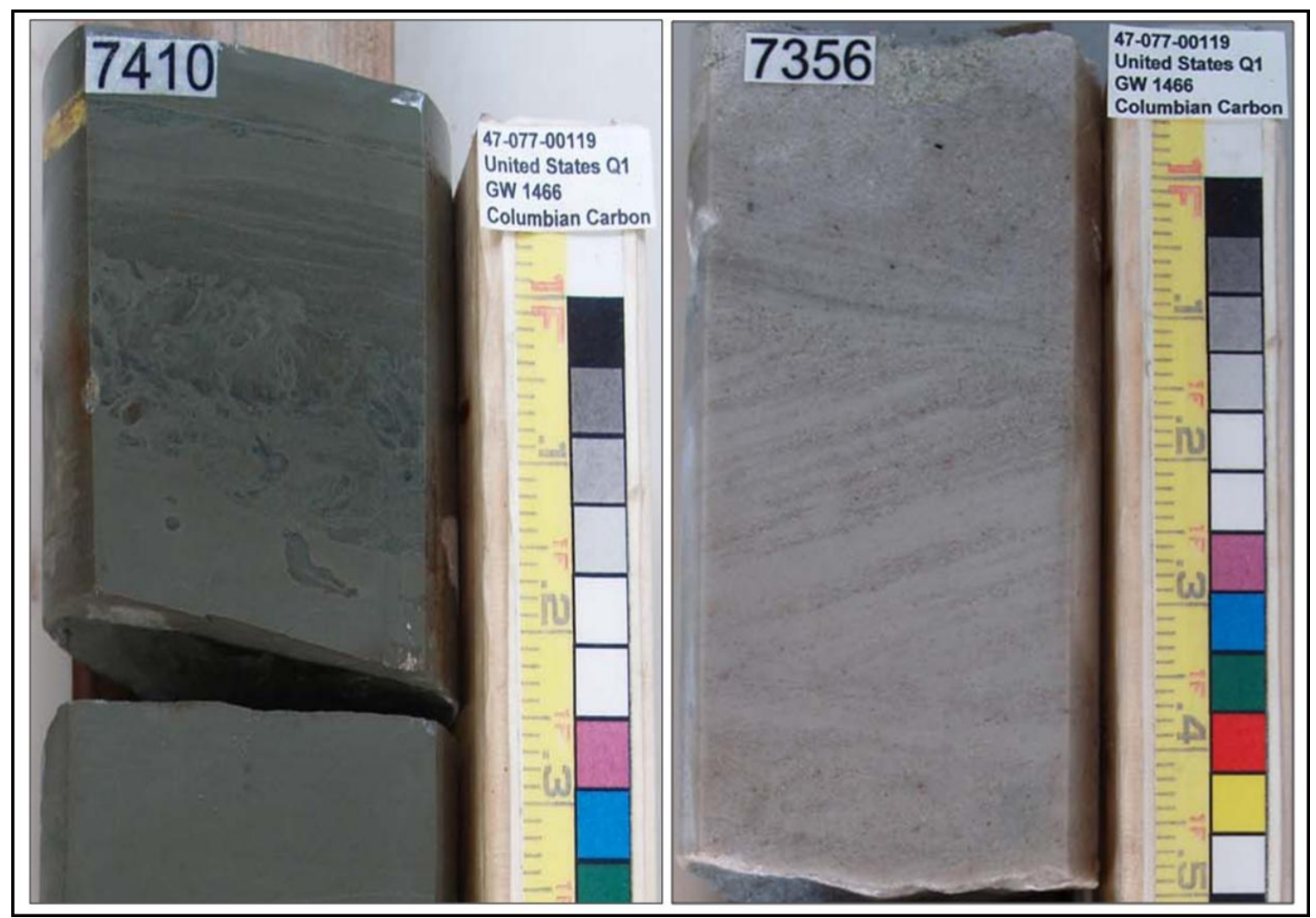

Figure 15: Left: low angle laminations interrupted by extensive burrowing and bioturbation in core from Preston County, West Virginia (Columbian Carbon Company, API\# 4707700119) Depth is approximately 7,410 feet (2,258.6 meters). Right: Bidirectional cross-bedded sandstones in the middle member at 7,356 feet (2,242 meters).

\section{Central West Virginia}

A partial interval of the middle member was cored in Clay County (United Fuel Gas Company, API\# 4701500513) and available for description. This member is approximately 17 feet (5.18 meters) and contains medium to dark gray shale interbedded with fine-grained sandstone with horizontal to low-angle laminations. Other sedimentary features include trough (hummocky?) cross-laminations, scoured surfaces, and graded bedding (Figure 16). Laughrey (1984) described hummocky sets of cross-laminae and near-horizontal fine laminae in northwest Pennsylvania within his Unit 2 of the Cabot Head Shale. In Kanawha County the middle member in well cuttings (API\# 4703900662) is approximately 50 feet (15.24 meters) of gray shale with considerable amounts of interstratified siltstone and sandstone beds (Martens, 1945). 


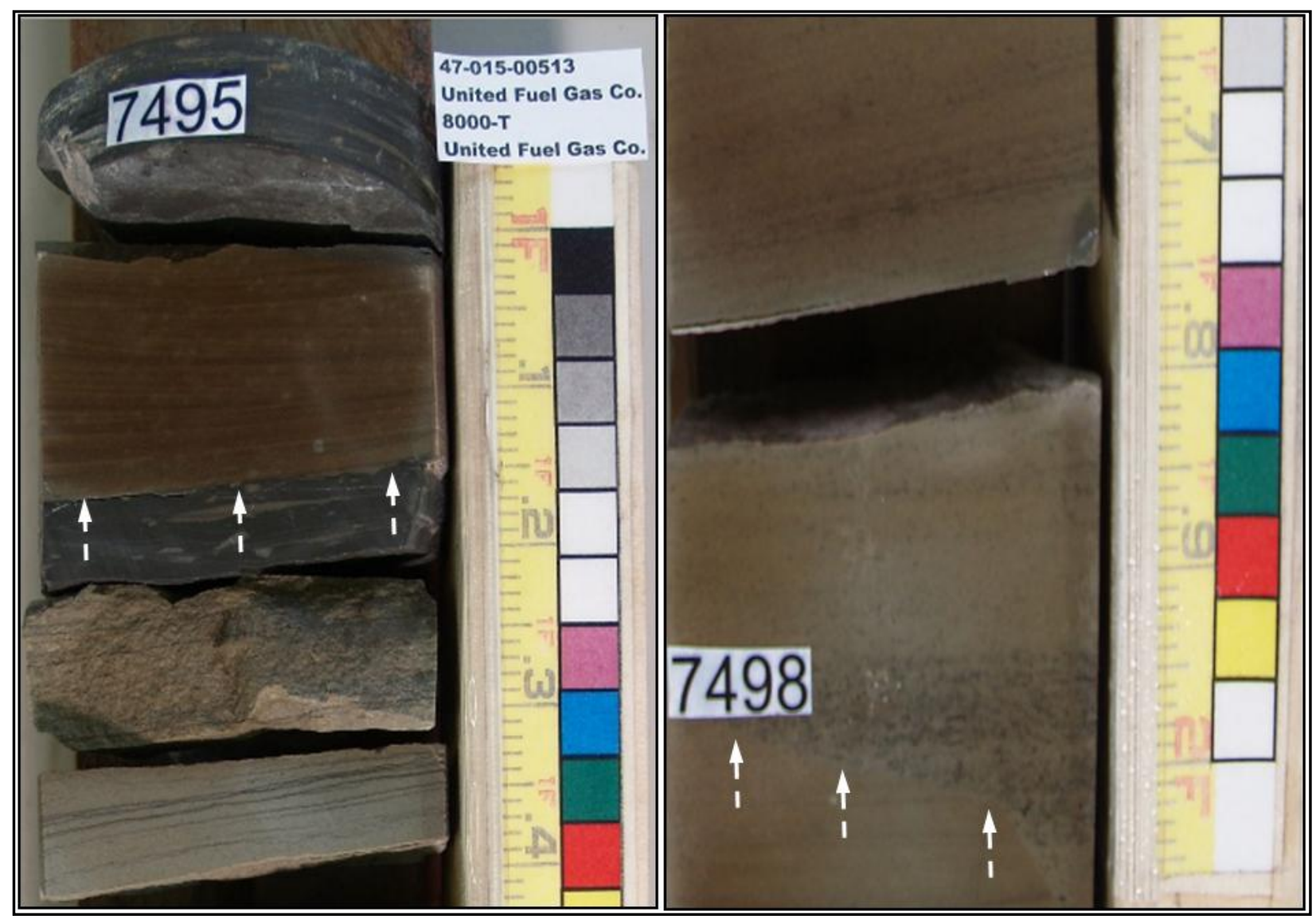

Figure 16: Featured sedimentary structures in core from Clay County, West Virginia (United Fuel Company well, API\# 4701500513). The image on the left displays interbedded medium to dark gray shale with laminated fine grained sandstone. The white arrows on the image show a scoured surface overlain by trough (hummocky?) cross-bedding (Depth is approximately 7,495 feet $(2,284.5$ meters)). To the right, at a depth of approximately 7,498 feet $(2,285.4)$, very fine-grained laminated sandstone with scoured surfaces and graded bedding is present. The white arrows indicate scouring overlain by graded bedding.

\section{Western West Virginia}

Biologic features are common in the middle member. Core in Wood County (Power Oil Company, API\# 4710700351) is described as 45 feet (13.7 meters) of dark gray shale, containing an occasional fossil, with numerous thin sandstone and siltstone laminations (Bayles et al., 1956). Within the same county, well cuttings (API\# 4710700099) are described by Martens

(1945) as 49 feet (14.9 meters) of gray to grayish-green silty shale with a considerable amount of light gray to white siltstone and very fine sandstone.

To the southwest the lithology of the middle member can be summarized as a greenish to reddish gray, soft, moderately fissile, unfossiliferous, dolomitic shale that is slightly silty, pyritic, 
and glauconitic (Lukasik, 1988). Samples from well cuttings in Cabell County (API\# 4701100537) are described as 42 feet (12.8 meters) of slightly to very silty, medium-gray shale. East of Cabell County, cuttings from Boone County (API\# 4700500402) are described as 42 feet (12.8 meters) of gray shale, with gray to green siltstone, and some light brown dolomite (Martens, 1945). More descriptive well cuttings are available in Appendix II.

\subsection{Middle Member Facies Interpretation}

\section{Eastern West Virginia}

To the northeast in Preston County, the cross-bedded, medium- to coarse-grained sandstone with shale drapes is interpreted dominantly a tidal-influenced marine interval; this interval may be the equivalent of the Cabot Head Shale to the west that was deposited during a relative rise in sea level (Castle, 1998). Bidirectional cross-bedding in core from Preston County indicates a tidal influenced depositional environment. The serrated pattern observed in the gamma ray log, representative of interbedded sandstone and shale also supports a tidalinfluenced environment. Sandstone and shale interbedding is common in intertidal flats and river estuaries; during periods of current activity sand layers are deposited and during stand-still phases of high- and low-water tides muddy layers are deposited (Reineck and Singh, 1980). The interval that occurs upwards in section is a predominantly estuarine environment deposited during a highstand progradation (Castle, 1998). The thickness increase of dark-gray shale to the southwest in Harrison County indicates that there is a transition to more of a marine origin. For this study, the middle member is interpreted as being deposited in a tidal-influenced muddy estuarine embayment. 


\section{Central and Western West Virginia}

For this study the middle member is interpreted to be deposited in a storm-dominated, low energy offshore marine environment. In Clay County, the medium to dark gray shale interbedded with silt and sand indicates an offshore marine deposit interrupted by scoured surfaces during storms and graded bedding created as the sediments settled after storm episodes. The presence of fossils in the middle member in the Power Oil Company core also suggests a marine origin, such as a prodelta (Reineck and Singh, 1980). In this offshore setting there was a diminished clastic influx, which allowed for high productivity of organic matter, reflected in gamma ray logs with values exceeding 200 API.

A ravinement surface may be present in central West Virginia (Figure 17). These scoured surfaces are cut by fluvial, wave and/or tidal processes during a landward shoreline shift (Catuneanu, 2006). The amount of scouring determines whether the beach and underlying fluvial transgressive facies is or is not preserved and the ravinement surface may truncate older strata. The facies below this surface vary from fluvial to coastal or shallow-marine and facies above the surface are shallow marine (Catuneanu, 2006).

\section{Middle Member Isopach and Paleoenvironment Map}

The thickness of the middle member was calculated from the top of the middle to the top of the lower member using 108 wells (Figure 17). The thickness ranges from approximately $0-$ 125 feet $(0-38.1$ meters $)$ and is oriented northeast to southeast and thickens to the northwest. It thins to the southeast and as with the lower member; this middle member is not present in the southeast region of the study area. Like the lower member, the thickness trend in the northeast is interpreted to be associated with higher rates of subsidence and possibly thickening caused by later orogenic events. Overall, the northeast-southwest thickness trend can be attributed to 
deposition during a time of maximum subsidence related to thrusting and marine flooding in an offshore environment (Duke et al., 1991).

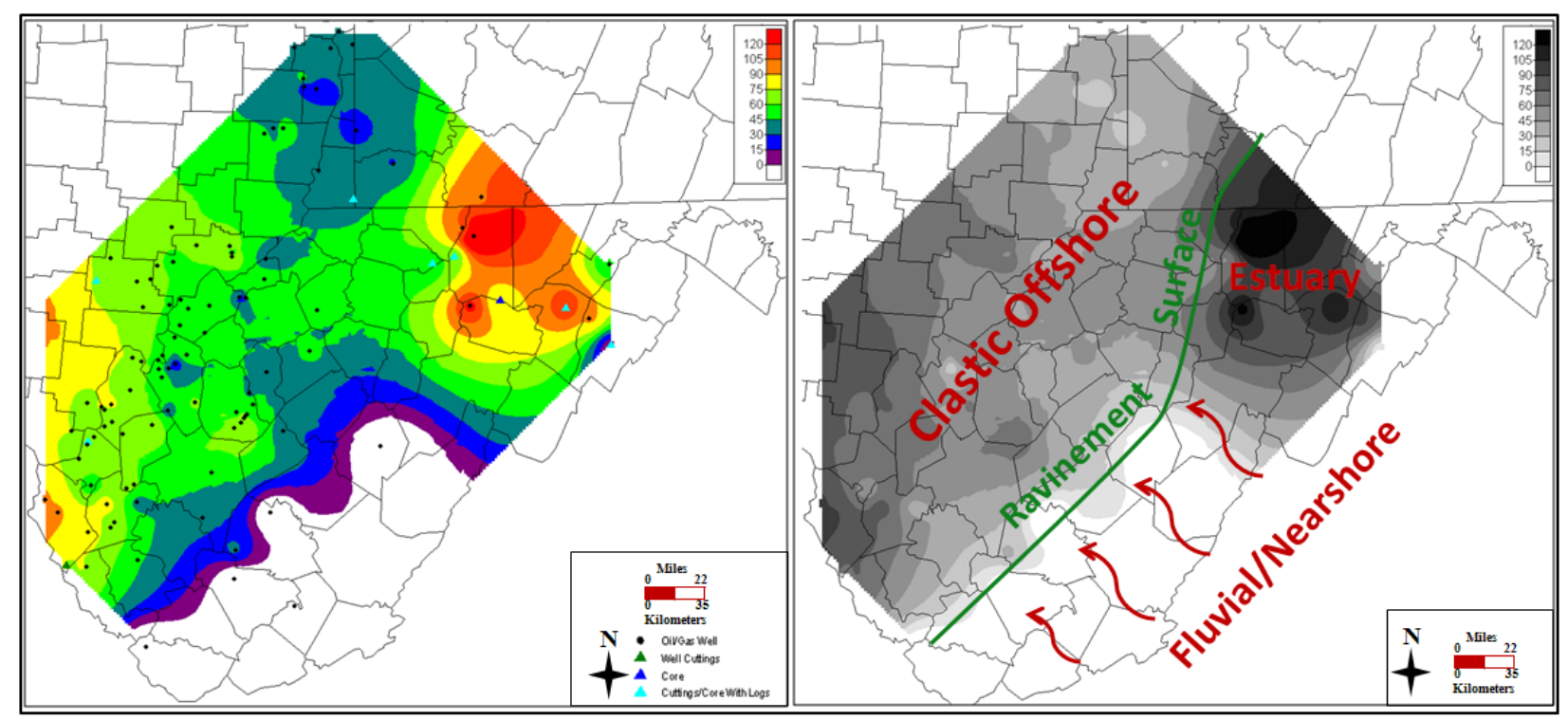

Figure 17: Left: Thickness map of the middle member. Overall there is a northeast-southwest trend, with the thickest deposits to the northeast. The thickness trends in the northeast are likely a result of increased subsidence. The middle member thins to the southeast and is eventually pinches out. Right: Paleoenvironment interpretation of the middle member 


\subsection{Upper Member Description}

A single type log cannot be assigned to the upper member because the formation thickness, facies and log response is considerably varied throughout the study area. Type logs from four locations within the study area illustrate the variation in wireline log response including thickness and shale content (Figure 18). A list of previously described and interpreted depositional facies of the upper member is provided (Table 4).

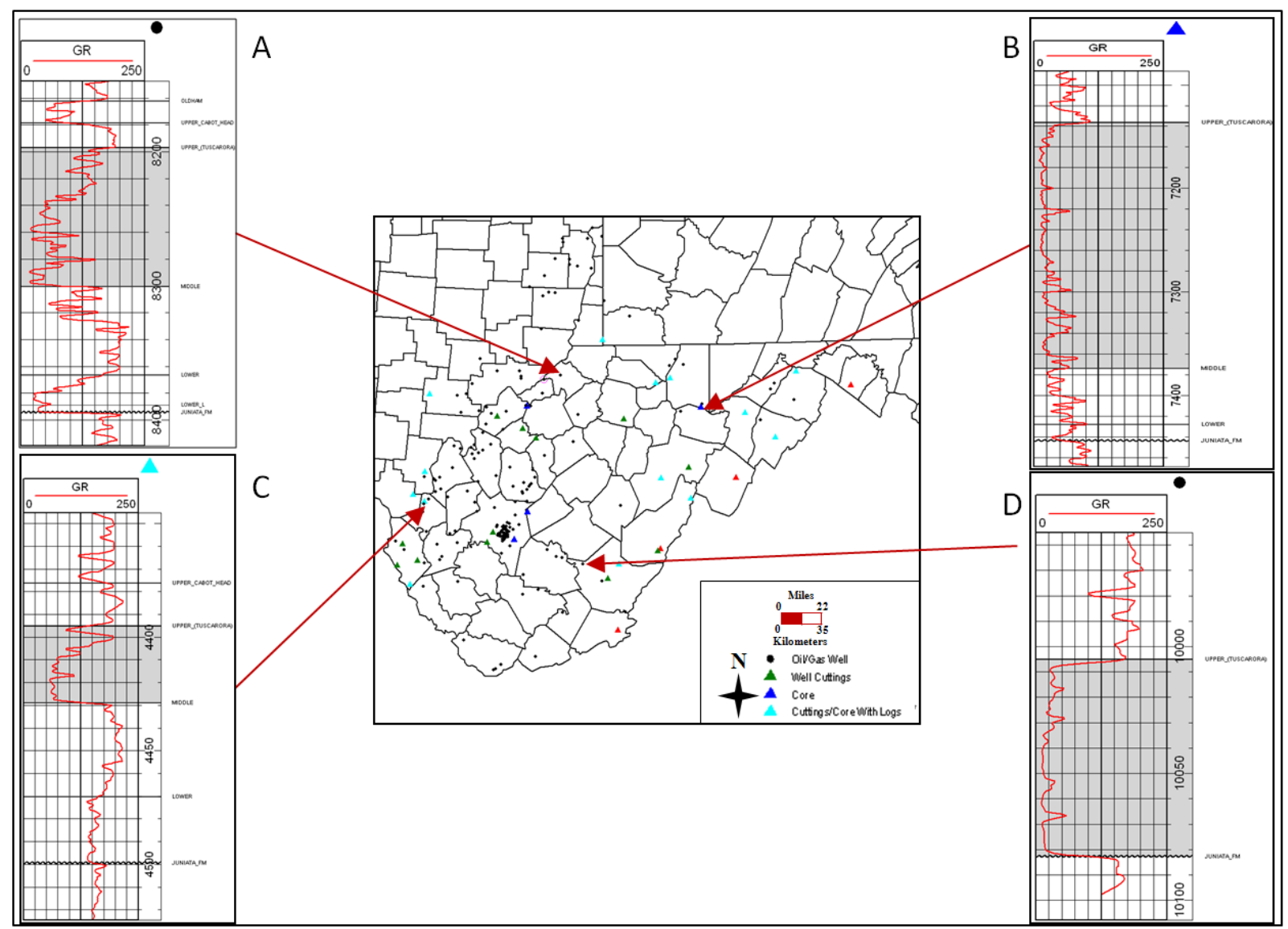

Figure 18: Four type logs and well locations used in this study of the upper member (highlighted in gray) throughout West Virginia (A: API\# 4707301883, B: API\# 4707700119, C: API\# 4701100537, D: API\# 4702500022). Note the differences in thickness, gamma ray patterns, and shale content 


\begin{tabular}{|c|c|c|c|c|}
\hline Author & Formation & Location & Description & Depositional Environment \\
\hline Castle (1998) & $\begin{array}{l}\text { Tuscarora } \\
\text { Sandstone }\end{array}$ & $\begin{array}{c}\text { Preston County, } \\
\text { West Virginia }\end{array}$ & $\begin{array}{l}\text { Very fine- to coarse-grained sandstone, common shale rip-up clasts, } \\
\text { quartz pebbles, trough cross-bedding, scouring; ripple cross- } \\
\text { laminations, and burrowing occurs at the top of the cored interval }\end{array}$ & Fluvial \\
\hline Cotter (1983) & $\begin{array}{l}\text { Tuscarora } \\
\text { Sandstone }\end{array}$ & $\begin{array}{c}\text { Central } \\
\text { Pennsylvania }\end{array}$ & $\begin{array}{l}\text { Western Cross-Laminated Facies: Medium- to coarse-grained, } \\
\text { quartz-rich sandstone (quartz arenite); cross-laminated beds of very } \\
\text { coarse sandstone and conglomerate at proximal outcrop exposures } \\
\text { bound by wavy, nonparallel bed surfaces; minor thin black shale beds } \\
\text { in southeastern exposures; rare basal scour, sharp contacts; } \\
\text { Monocraterion and Arthrophycus }\end{array}$ & $\begin{array}{l}\text { Cross-laminations forms as sand wave } \\
\text { complexes in the marine shelf } \\
\text { environment }\end{array}$ \\
\hline Yeakel (1962) & $\begin{array}{l}\text { Tuscarora } \\
\text { Sandstone }\end{array}$ & $\begin{array}{l}\text { Eastern West } \\
\text { Virginia }\end{array}$ & $\begin{array}{l}\text { Medium- to fine-grained sandstone, local basal conglomerates, } \\
\text { northwest-oriented festoon cross-bedding, minor ripple marks, } \\
\text { horizontal laminations, Arthophycus and Skolithos }\end{array}$ & Fluvial \\
\hline \multirow{2}{*}{ Castle (1998) } & $\begin{array}{l}\text { Grimsby } \\
\text { Sandstone }\end{array}$ & $\begin{array}{l}\text { Crawford } \\
\text { County, } \\
\text { Pennsylvania }\end{array}$ & $\begin{array}{l}\text { Shaley to medium-grained sandstone, gradationally sandier upward; } \\
\text { lower interval contains coarsening upward sequences; upper section } \\
\text { shows a decrease in grain size overlying scoured surfaces, shale rip-up } \\
\text { clasts, burrowing, rare phosphatic brachiopods, bidirectional cross- } \\
\text { bedding, reactivation surfaces, and cross-bed foresets }\end{array}$ & Tide-dominated shoreline \\
\hline & $\begin{array}{l}\text { Grimsby } \\
\text { Sandstone }\end{array}$ & Ontario, Canada & $\begin{array}{l}\text { Very fine-grained sandstone, coarsening upward sequence, ripple-cross } \\
\text { lamination, shale rip-up clasts, horizontal burrows, and trough cross- } \\
\text { bedding }\end{array}$ & Wave- and tide-influenced inner shelf \\
\hline $\begin{array}{l}\text { Dorsch et al. } \\
\text { (1994) }\end{array}$ & $\begin{array}{l}\text { Tuscarora } \\
\text { Sandstone }\end{array}$ & $\begin{array}{l}\text { Southwest } \\
\text { Virginia }\end{array}$ & $\begin{array}{l}\text { "Upper" Tuscarora: fining- and thinning-upward succession, } \\
\text { predominantly trough cross-stratified, trace fossils } \\
\text { Contact: Tuscarora unconformity } \\
\text { "Lower" Tuscarora: thin- to medium-bedded quartzarenite with } \\
\text { numerous mudstone interbeds; sandstone beds contain trough cross- } \\
\text { stratification, abundant trace fossils }\end{array}$ & $\begin{array}{l}\text { "Upper": Storm-dominated deposits } \\
\text { of upper and lower shoreface } \\
\text { "Lower": Storm-dominated, shallow- } \\
\text { marine deposits }\end{array}$ \\
\hline Castle (2001) & $\begin{array}{c}\text { Grimsby } \\
\text { Sandstone }\end{array}$ & Eastern Ohio & $\begin{array}{l}\text { Very fine- to medium-grained sandstone, common horizontal and low- } \\
\text { angle cross-bedding, wave-ripple cross-lamination common in smaller } \\
\text { grained intervals, phosphatic brachiopods, horizontal and vertical } \\
\text { burrows }\end{array}$ & Lower and upper shoreface \\
\hline
\end{tabular}

Table 4: Previously described and interpreted depositional environments of the upper member in the Appalachian basin. 


\section{Eastern West Virginia}

In the core from Preston County (API\# 4707700119) thick, coarse-grained deposits with occasional thin, black shale beds were deposited in the proximal foreland (Castle, 1998). Upwards from the middle member, burrowing disappears, and shale rip-up clasts and pebbles are abundant (Castle, 1998). This investigation found that burrowing and bioturbation does continue, though rarely, throughout the entire interval. Additionally, common trough crossbedding, low-angle to horizontal laminations, graded laminae, and scoured bases occur (Figure 19). Towards the top of the cored interval, burrowing increases and some ripple crosslaminations occur. Castle (2001) places this member into a sequence termed "upwardcoarsening sequence type A". This sequence is characterized by an upward increase in grain size, thickness, and sandstone-to-shale ratio. The gamma-ray signature in this well supports an overall coarsening-upward sequence with thin shale interbeds and towards the top of the interval there is a fining-up sequence (Figure 18b). Folk's (1960) study of Tuscarora outcrops in the eastern West Virginia panhandle subdivides the upper member into lower and upper white Tuscarora Sandstone. The lower white is approximately 95 feet (28.9 meters) thick with moderate amounts of gravel and moderate to poor sorting. Additionally, scattered cross-bedding occurs. The upper white Tuscarora is 115 feet (35 meters) thick with small amounts of gravel, good to moderate sorting and scattered cross-bedding. The grains in the upper interval are more rounded than the grains of the lower interval, which are moderately rounded. In contrast to the muddy matrix of the basal red Tuscarora, the upper Tuscarora lacks any silt and detrital clay. 


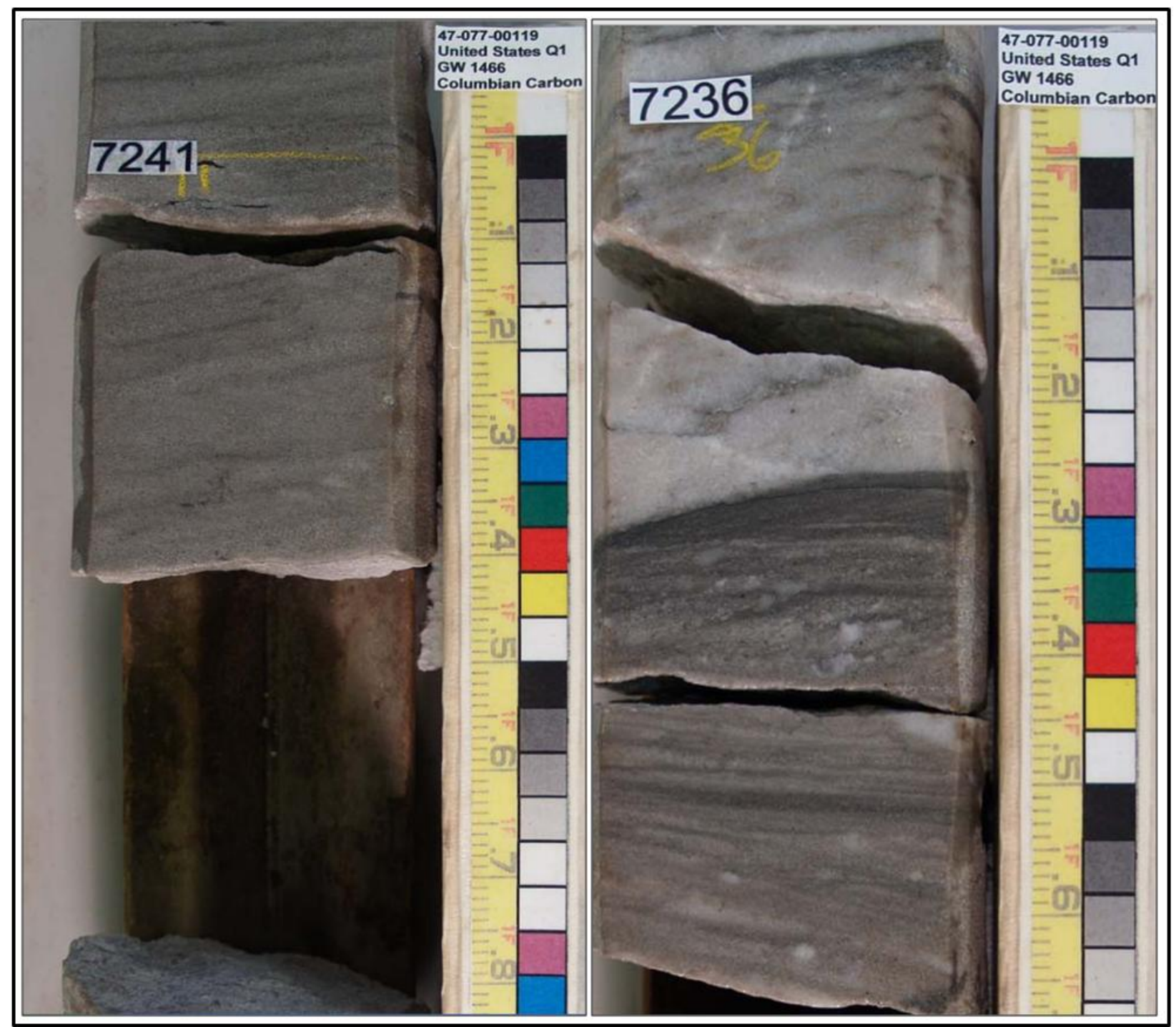

Figure 19: Core photographs from the Columbian Carbon Company well in Preston County, WV (API\# 4707700119); Left: Coarse grained cross beds at 7,241 feet (2,207 meters). Right: Coarse- to pebbly-grained cross beds and scoured surfaces at approximately 7,236 feet (2,206 meters).

A neutron-density crossplot from Fayette County illustrate that the upper member is a low porosity and quartz-rich unit (Figure 20). The gamma ray pattern is blocky with several fining-up sequences. 


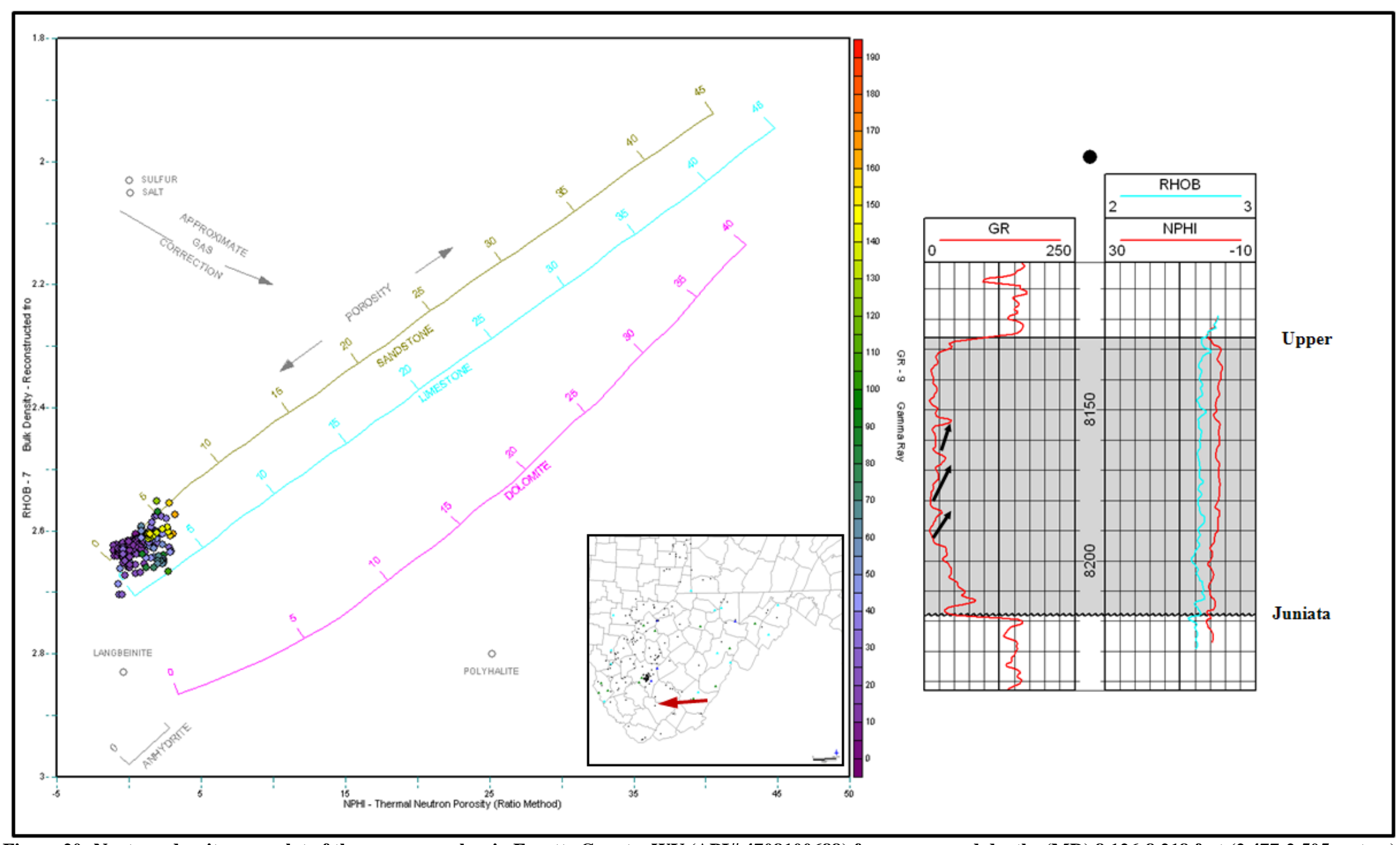

Figure 20: Neutron-density crossplot of the upper member in Fayette County, WV (API\# 4708100688) from measured depths (MD) 8,126-8,218 feet (2,477-2,505 meters). In this well the crossplot reveals a quartz-rich lithology corresponding to the overall low gamma-ray values; the gamma ray also indicates several fining-upward

sequences indicated by the black arrows. 


\section{Central West Virginia}

To the west in Kanawha County, 60 feet (18.3 meters) of core is described as an overall fining upwards sequence, which is also evident in the bell-shaped gamma-ray curve (Figure 21). The lowest 4 feet (1.2 meters) of the core is pebbly- to coarse-grained with low-angle beds with common graded or inversely graded laminae. Throughout these laminae, medium- to finegrained sandstone is distributed and sorting in the beds is moderate to poor. Several finingupward sequences occur as well (Bruner, 1983).

Above the lower pebbly- to coarse-grained interval is 74 feet (22.6 meters) of burrowed, medium- to fine-grained sandstone with low-angle to horizontal beds. Interbedded low-angle, very coarse- to pebbly-grained sandstone occurs as well. The coarse- and fine-grained sequences typically are fining-upward sequences: the base of these display low-angle interbedded pebblyto coarse-grained and medium- to fine-grained sandstone beds. These are overlain by finegrained beds with horizontal to low-angle laminae that are capped with burrows and bioturbated intervals. Rare cross-bedding occurs (Bruner, 1983).

Towards the top of the interval, fine-grained beds increase in thickness and bioturbation increases as well. Graded beds, evenly laminated beds, interbedded coarse- and fine-grained beds, and thin beds with laminae containing shale clasts also occur (Bruner, 1983).

The upper interval is dominated by fine- to very fine-grained sandstone with low-angle to horizontal beds. Additionally, fine-grained heavy minerals occur in thin laminae. Burrowing commonly interrupts laminae and some climbing ripples are present. The upper 2 feet $(0.6$ meters) is described as a sequence of red sandstone and shale that are horizontally laminated, burrowed, and locally within the interval has an abundance of shale clasts (Bruner, 1983) (Figure 22). 


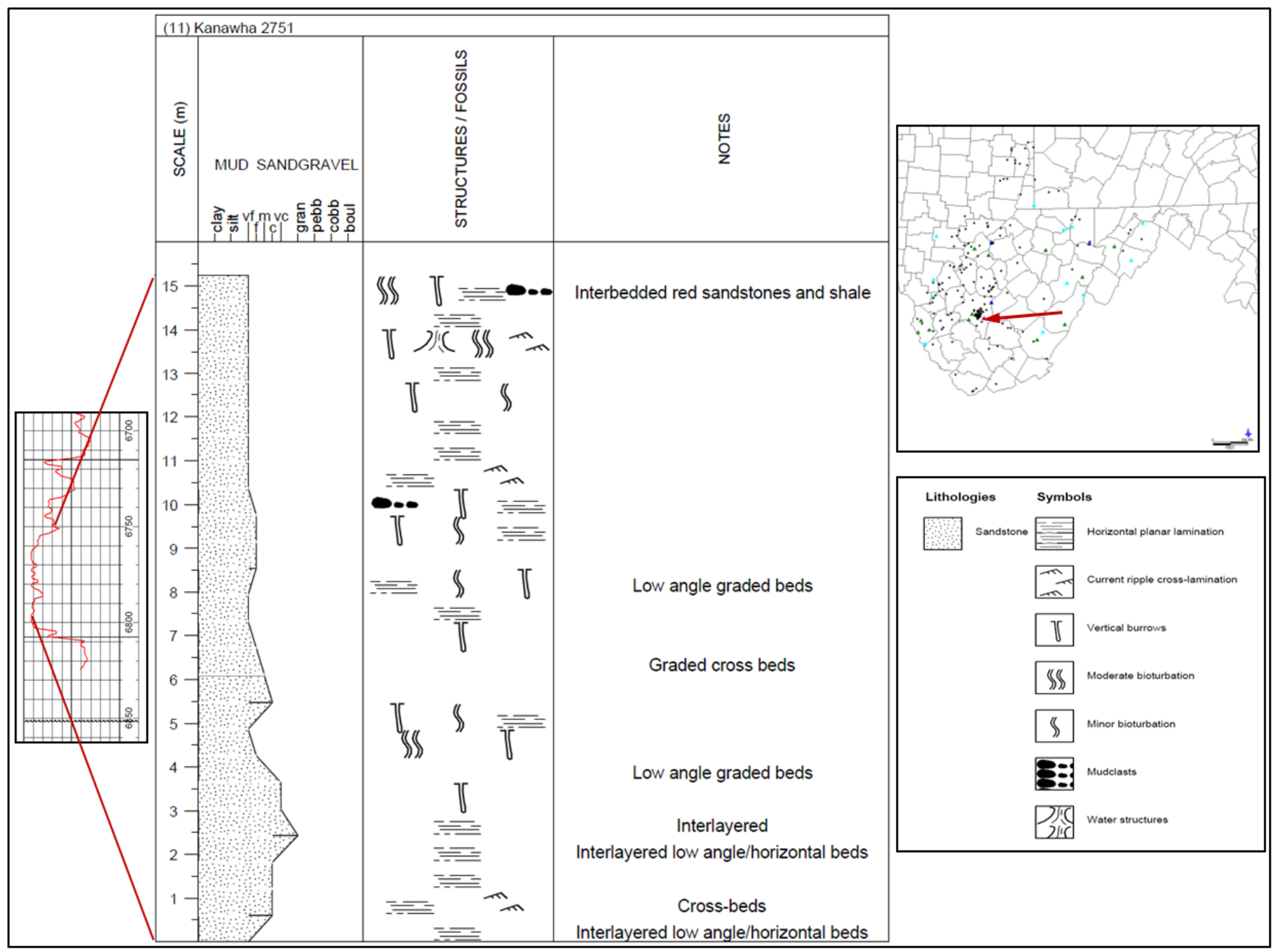

Figure 21: Gamma ray log and corresponding core description of the Tuscarora Sandstone in Kanawha County, WV (API\#4703902751, 6,750 to 6,801 feet MD (2,0572,073 meters). Grain size in second column from the left is based on observed average grain size. (Modified from Bruner, 1983). 


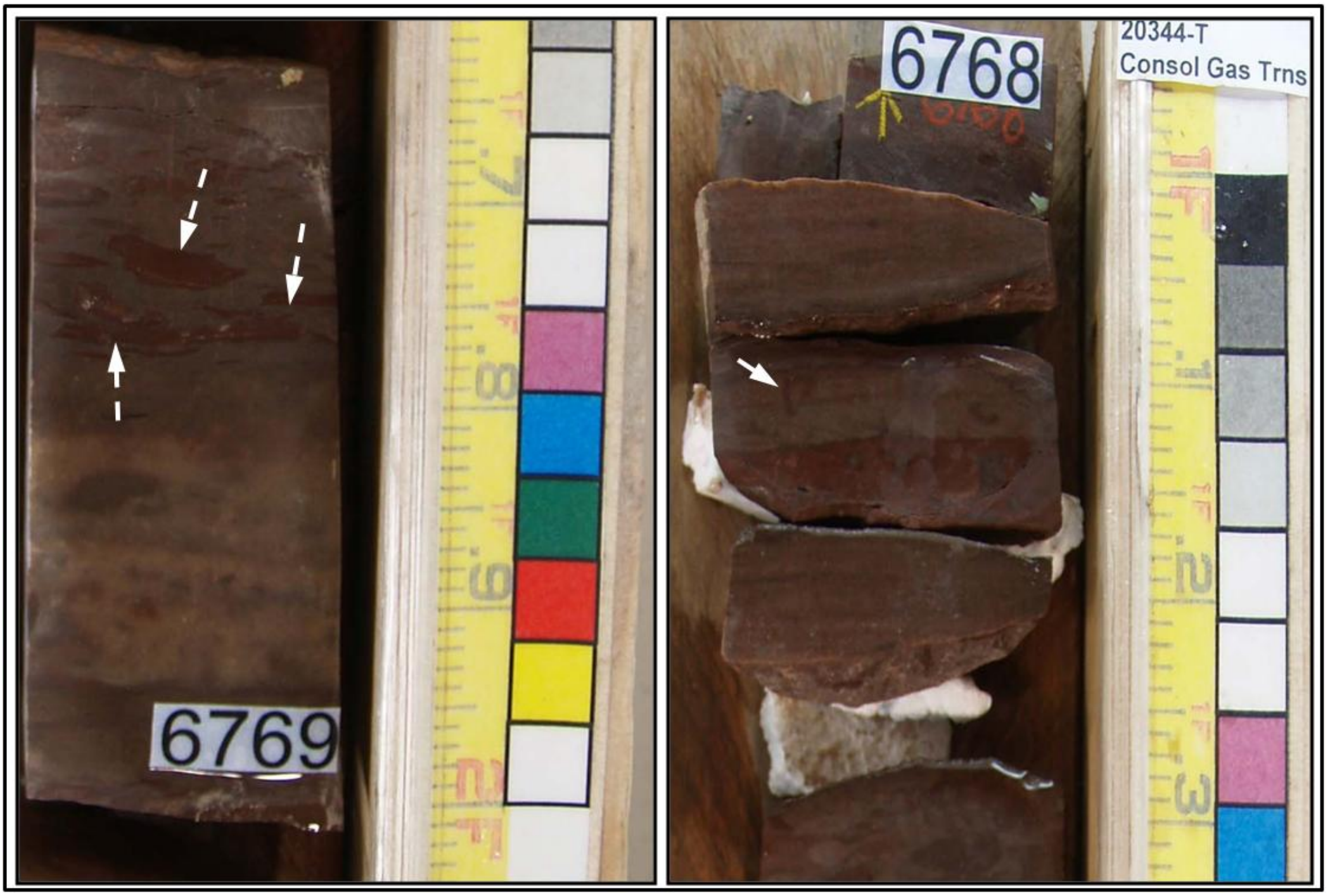

Figure 22: Left: Interbedded red shale and sandstone with shale clasts (white arrows) at approximately 6,769 feet (2,063 meters). Right: Interbedded red shale and sandstone at approximately 6,768 feet $(2,063$ meters $)$; white arrow points to burrowing. 
In adjacent Clay County a third core description of the upper member was available (United Fuel Company, API\# 4701500513). Castle (2001) placed the upper member from this core in what he designates an "upward-fining sequence". This sequence is described as thick sandstone that directly overlies a basal erosion surface with an upward fining trend from sandstone to shale. Grain sizes vary between very coarse to very fine, which decrease upward. In proximal foreland basin regions such as Clay County, quartz granules and pebbles and shale rip-up clasts are concentrated in thin to medium beds throughout this sequence (Castle, 2001). Trough cross-bedding is common as well as sharp and irregular bases.

Similar sedimentary features occur in the core from Clay and Kanawha counties. The interval does fine upward and contains coarse- to pebbly-grained planar cross bedding interbedded with fine- to medium-grained sandstone and siltstone at the base. Upwards, grain size decreases, burrowing increases, and low-angle to horizontal laminations are the most common sedimentary structures. Occasional cross-laminations and cross-bedding also occur (Figure 23). 


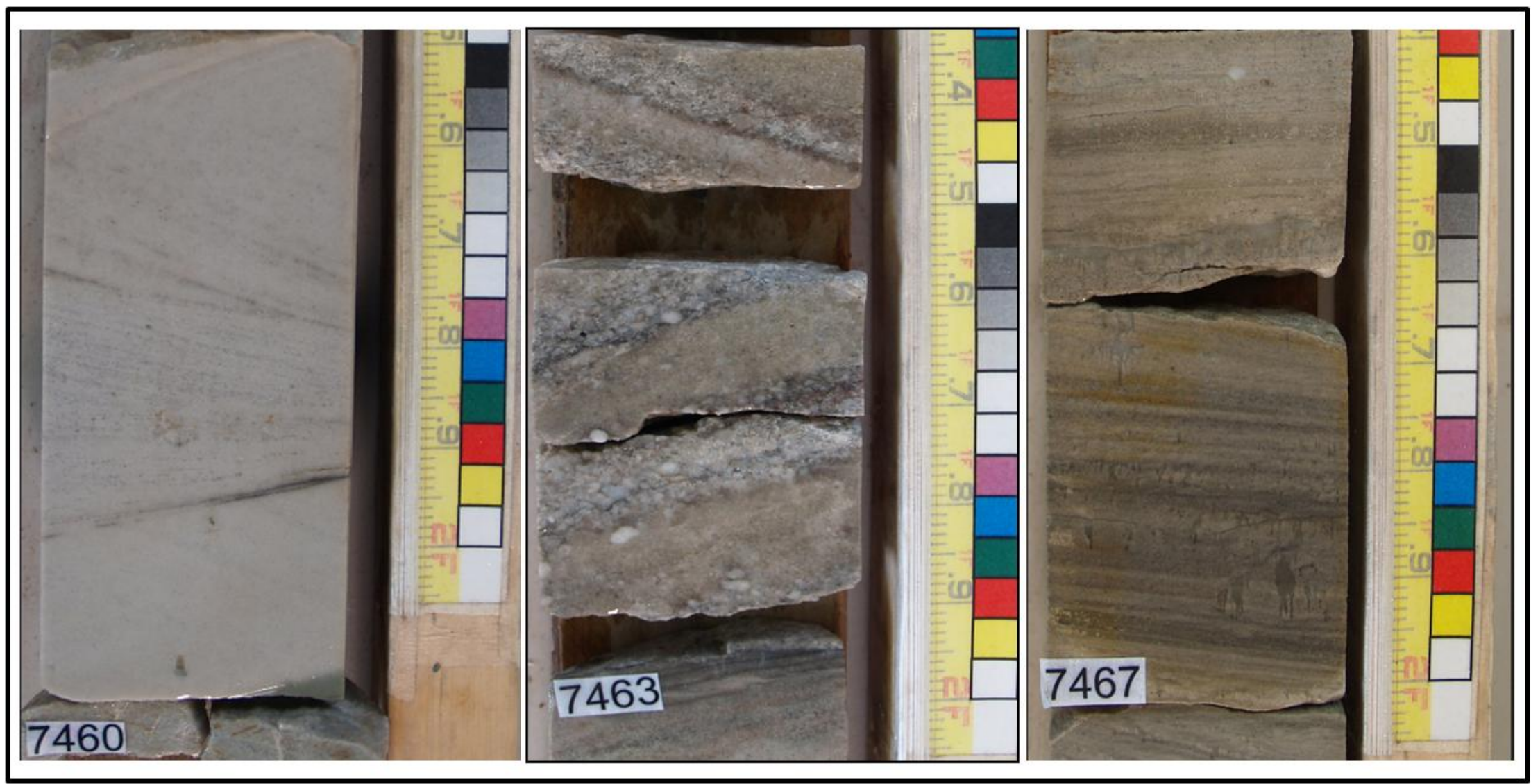

Figure 23: Left: Graded cross-bedding at approximately 7,460 feet (2,274 meters). Center: Coarse- to pebbly-grained planar beds interbedded with fine- to mediumgrained sandstone (trough cross-bedding at top of core photo?) at approximately 7,463 feet (2,275 meters). Right: Fine- to coarse-grained low-angle laminations interrupted by vertical burrows at approximately 7,467 feet $(2,276$ meters $)$. 


\section{Western West Virginia}

To the west in some areas the upper member shows an increase in the amount and thickness of shale beds (Figure 18a). In Wood County, the upper member in the Power Oil Company core (API\# 4710700351) contains very fine-grained sandstone interbedded with many dark gray to black shale beds. The sandstones contain shale fragments and some of the shale beds have sandstone pebbles and display worm markings (Arthrophycus?) (Bayles et al., 1956). To the north in Marshall County, well cuttings (API\# 4705100539), are described predominantly as 160 feet (48.8 meters) of pale red to white fine- to very fine-grained sandstone. Towards the top of the section, there is in increase in interbedded medium dark-gray shale (Diecchio, 1985).

To the southwest well cuttings from Cabell County, WV (API\# 4701100537) are described as 20 feet (6.1 meters) of very well sorted white siltstone that is subangular to subrounded with a trace amount of gray shale (Lukasik, 1988). Similarly, to the west in adjacent Gallia County, Ohio, well cuttings are mostly white to light tan siltstone, moderately well sorted, subangular to subrounded and pyritic; medium gray shale with dolomitic siltstone and limestone are also present (Lukasik, 1988). Further to the south in Wayne County (API\# 4709900465), the upper member is described as dominantly a light gray to white, very fine- to fine-grained sandstone with minor amounts of shale and siltstone (WVGES, 2013).

\subsection{Upper Member Facies Interpretation}

\section{Eastern West Virginia}

In Preston County burrowing in the middle member suggests brackish-to-marine influence, possibly estuarine (Castle, 1998). Upwards from this member the marine influence diminishes and is dominated by coarse-grained deposits and trough-cross bedding, possibly deposited as fluvial channels. The transition from marine-to-estuarine-to-fluvial sequence is 
interpreted as progradation attributed to subsidence and high volumes of detrital sand sourced from the adjacent Taconic highlands (Castle, 1998). This shallowing-upward trend is also indicative of basinward progradation. The log response of the upper member is an overall clean sandstone with some shale beds (high gamma-ray), which support a fluvial environment (Figure $18 b)$.

Castle's interpretation may be more complex than simply a fluvial environment. The reverse graded bedding seen in the interval was also recognized in central Pennsylvania outcrops, interpreted to have formed in a paralic zone (Cotter 1983). It is possible that the sedimentary structures in the core from Preston County are similar to structures seen in Cotter's outcrop: trace fossils throughout the interval are indicative of a marginal-marine setting, possibly containing a fluvial component within it. In central Pennsylvania, an interplay between a rise in sea level and an increased sediment supply from the uplifted Taconic highlands caused shoreline retrogradation with some temporary local progradation caused by fluvial deposits, as observed in outcrop (Cotter, 1983).

In eastern West Virginia, Yeakel (1958) interpreted the Tuscarora Sandstone to be deposited in a fluvial environment given the festoon cross-bedding and unimodal paleocurrent orientation. The presence of the trace fossil Arthrophycus as well as the abrasion present on the grains; however, supports a near-shore depositional setting (Folk, 1960). The sudden increase in winnowing and abrasion by wave or current action may have been caused by increase in relief due to a tectonic pulse in the highlands (Folk, 1960). The surf action had enough energy to remove any clay and silt, however, not enough energy to allow for good sorting. Evidence of abrasion is further corroborated by the absence of soft slate and low-rank phyllite fragments as well as the clay galls that are present in the lower "red" Tuscarora Sandstone. The presence of 
scattered cross-bedding indicates that this high energy nearshore environment had shifting currents and waves (Folk, 1960). Upwards in section, there is a decline in the amount of gravel, which is attributed to declining relief in the source area due to erosion (Folk, 1960). The increased rounding of the grains and scattered cross-bedding is then interpreted to have been deposited in a high-energy beach environment with decreased deposition, allowing for increased abrasion and sorting.

Described outcrops in the southeast have many characteristics of terrestrial and marine deposition. The occurrence of coarse-grained and local conglomerates at the base could be indicative of a braided-fluvial facies. Upwards in section, the appearance of Skolithos and the fining-upward nature indicates a marine influence caused during a rise in sea-level. Skolithos are commonly present in the less active intertidal zones of sandy shores (Blatt et al., 1980).

\section{Central West Virginia}

In Kanawha County it is difficult to interpret the depositional environment because $37 \%$ of the core is missing and the maximum continuous section is only 3.1 feet ( 0.9 meters); however, the sedimentary structures, sequences, and grain size variations suggest that the Tuscarora Sandstone was deposited as coastal sand in a high-energy environment with shallow water and high sedimentation rates: such paralic environments include shoreface, littoral and tidal flat environments (Bruner, 1983). The overall upward fining sequence in core and gamma ray log are interpreted as an overall marine transgression (Figure 21). The occurrence of burrowed, interbedded red sandstone and shale indicate that the sediment was subaerially exposed, possibly in a tidal flat environment. In northwest Pennsylvania, red and green argillaceous sandstone was deposited within a prograding sand and mud complex on top of coastal sands (Laughrey, 1984). 
In Clay County, the sharp basal erosion surface is overlain by coarse material which fines upward (Castle, 2001). Castle correlates this basal erosional surface with the Cherokee discontinuity, however, in adjacent wells; the Cherokee discontinuity occurs in its normal position, above the Juniata Formation. It is possible that the sharp contact at the base of the upper member is an unconformity.

The upward decrease in grain size in the Clay County core and gamma ray log represents an overall upward decrease in depositional energy (Castle, 2001). The trough cross-beds with scoured bases and medium- to very coarse grained sandstone beds are interpreted to have accumulated in fluvial channels with no marine or tidal influence (Castle, 2001). Sedimentary structures observed in the core from Clay County have similar features to those that are seen in the foreshore environment, and may have been deposited as a longshore bar on a beach setting (Figure 23). After a storm event waves retain a higher energy for a period of time, thus depositing coarse sediment and as the wave energy decreases after several days these bars are built up as finer sands are deposited (Reineck and Singh, 1980).

The sharp contact that occurs at the middle and lower member in some places may be indicative of incision that occurred during a fall in sea-level. The gamma ray log response in central West Virginia generally has a smooth to serrated bell-shaped curve, with an abrupt contact at the base of the upper member and a gradational upper contact with the overlying shale of the Rose Hill Formation (Figure 21). This type of gamma ray log response may be indicative of a transgressive sand overlying an unconformity in an orogenic basin; in order for this to occur there must be an adjacent source area that can supply coarse to gravelly detritus that grades up into finer sandstone and subsidence must occur in order to accommodate thicker deposits (Wilson and Nanz, 1959). This criterion fits the sequence observed in wireline logs and core in 
Kanawha County; the Taconic highlands were a large enough source area to supply the coarse material at the base of the core, which subsequently fines upwards.

In central West Virginia, the strata may have been deposited in shallow incised-valley during a regional transgression (Castle, 1998; Ryder, 2000; Castle, 2001a,b; Hettinger, 2001). These deposits form in this particular region due to regionally low subsidence rates that allowed exposure and erosion to occur because the influence of eustatic sea-level change is greater than accommodation created related tectonism (Castle, 2001a). The vertical sequence of sedimentary structures and grain size does indicate that there is an overall upwards decrease in depositional energy and the presence of burrows and bioturbation throughout the interval indicates that this was in a marine-influenced environment to some degree.

There are two recognized types of estuaries: a tide- and wave-dominated. Due to a lack of bidirectional sedimentary structures in central West Virginia, it is possible that the upper member was deposited in a wave-dominated estuary. In wave-dominated estuaries, marine influence is less at the mouth of the river and fluvial energy usually decreases down-dip as the river approaches the sea. Marine influence decreases up-dip, therefore dividing estuaries into three zones: an outer zone dominated by marine processes, a low-energy central zone where there is a somewhat even balance between marine and fluvial energy, and an inner riverdominated zone (Dalrymple et al., 1992) (Figure 24). 


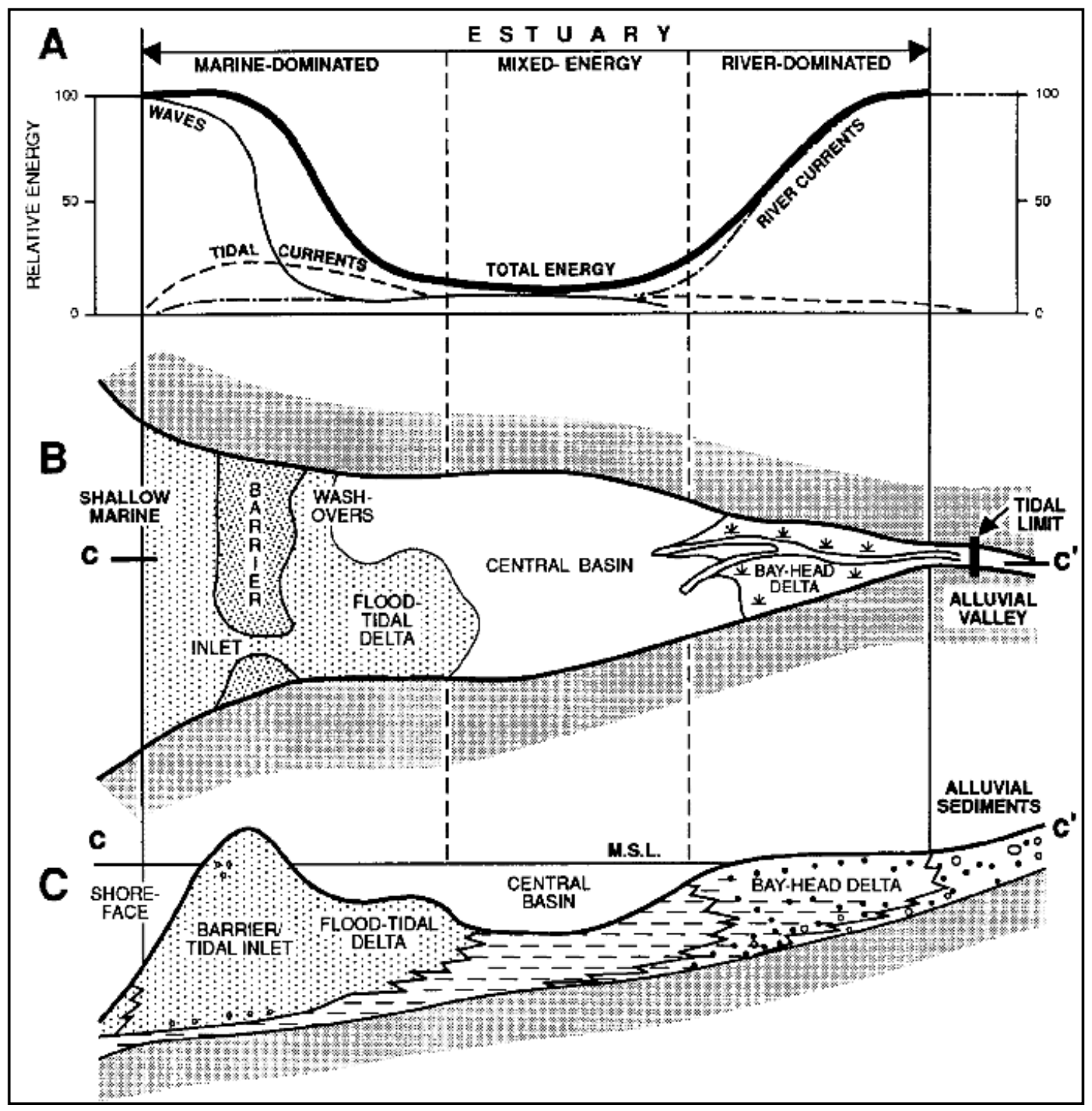

Figure 24: Relative energy levels (a), position of sedimentary facies in map view (b) and facies in cross-section in a wavedominated estuary (From Dalrymple et al., 1992)

\section{Western West Virginia}

Gamma-ray logs and core descriptions in the western region of the state indicate that there is an increased volume of black and dark shale in this region (Figure 18a and Power Oil Company core description from Wood County). Arthrophycus is considered marginal-marine and its appearance on dark shale beds also supports this interpretation. Interbedded sandstone and shale may form in a tidal-influenced environment. Muddy and silty deposits typically form on the bottom of lagoons with lower current velocities, which can show a high degree of 
bioturbation; the sandstone interbedded with the shale is brought in mainly during storms (Reineck and Singh, 1980). For this study, the interbedded dark shale and sandstone are interpreted as being deposited possibly in a beach lagoon in a nearshore shallow-water environment.

In New York and southern Ontario, the Medina Group is interpreted to have been deposited in deltas and shallow marine environments (Martini, 1970). Present in outcrops are channel fills, distributary channel fills merged with or cut into deltaic fringe sandstone, tidal-flats and sublittoral shale, and siltstone. Likewise in northwest Pennsylvania, a shallow marine environment is interpreted as well (Laughrey, 1984). The lower Grimsby Sandstone was deposited as upper shoreface and nearshore sands. Also recognized are fluvial deposits that incise the vertical sequence during times of relative shoreline stability, creating small deltas at the river mouths. It is possible that the westernmost region of the study area was deposited in the marine-influenced region of an estuary.

\section{Upper Member Isopach and Paleoenvironment Map}

The upper member, calculated from the top of the upper member to either the top of the Juniata Formation or the middle member, depending on the geographic location. The thickness ranges from approximately 50 - 460 feet ( 3 - 152.4 meters) with an average thickness of 147 feet (44.8 meters) (Figure 25). In the northeast the upper member follows the similar trend of the lower and middle members, with the thickest intervals located there that thin significantly to the west-southwest. In regions to the southwest the thinning is interpreted to be a result of a decrease in subsidence (distal foreland) and overfilling of the proximal foredeep. When the proximal foredeep has filled and the supply of sediment exceeds the rate of sedimentation, progradation onto the foreland ramp occurs (Castle, 2001a,b). During the waning phases of 
tectonism, sea-level can have a greater influence on sedimentation due to a lack of relief in the highlands and during this time, thicknesses may be less of those formed during active thrusting (Castle, 2001a,b).

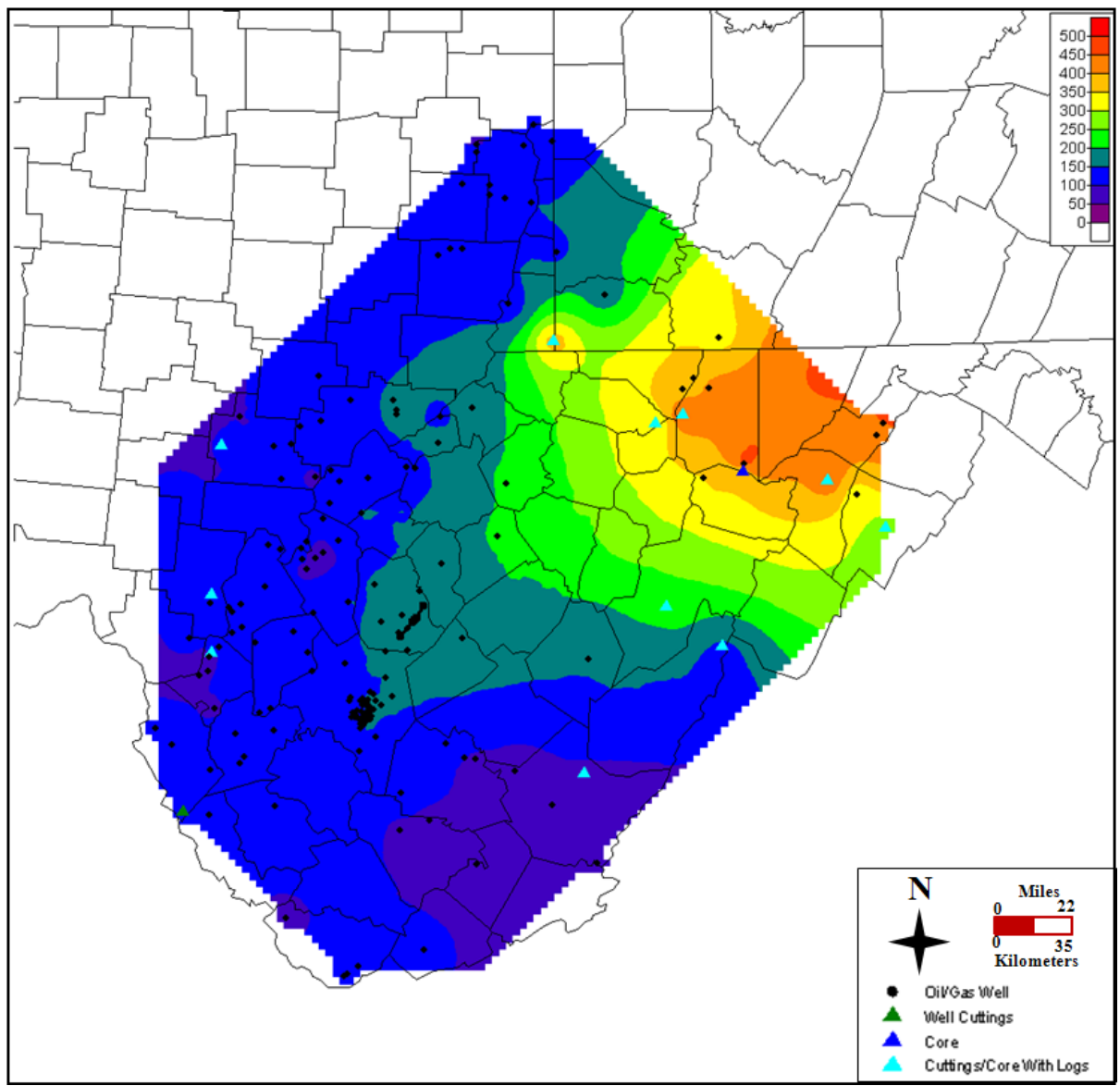

Figure 25: Isopach map of the upper member. The northeast contains the thickest intervals due to high accommodation and this trend decreases to the southwest.

The interpreted depositional environments of the upper member are depicted in Figures

26 and 27. The maps used for the interpreted paleoenvironments are the regressive and transgressive systems tracts maps that are discussed further in the next chapter. These maps were used because within the upper member fluvial and marine environments are interpreted. The fluvial deposits a result of a fall in sea level and the marine deposits are explained by a rise in sea level. 


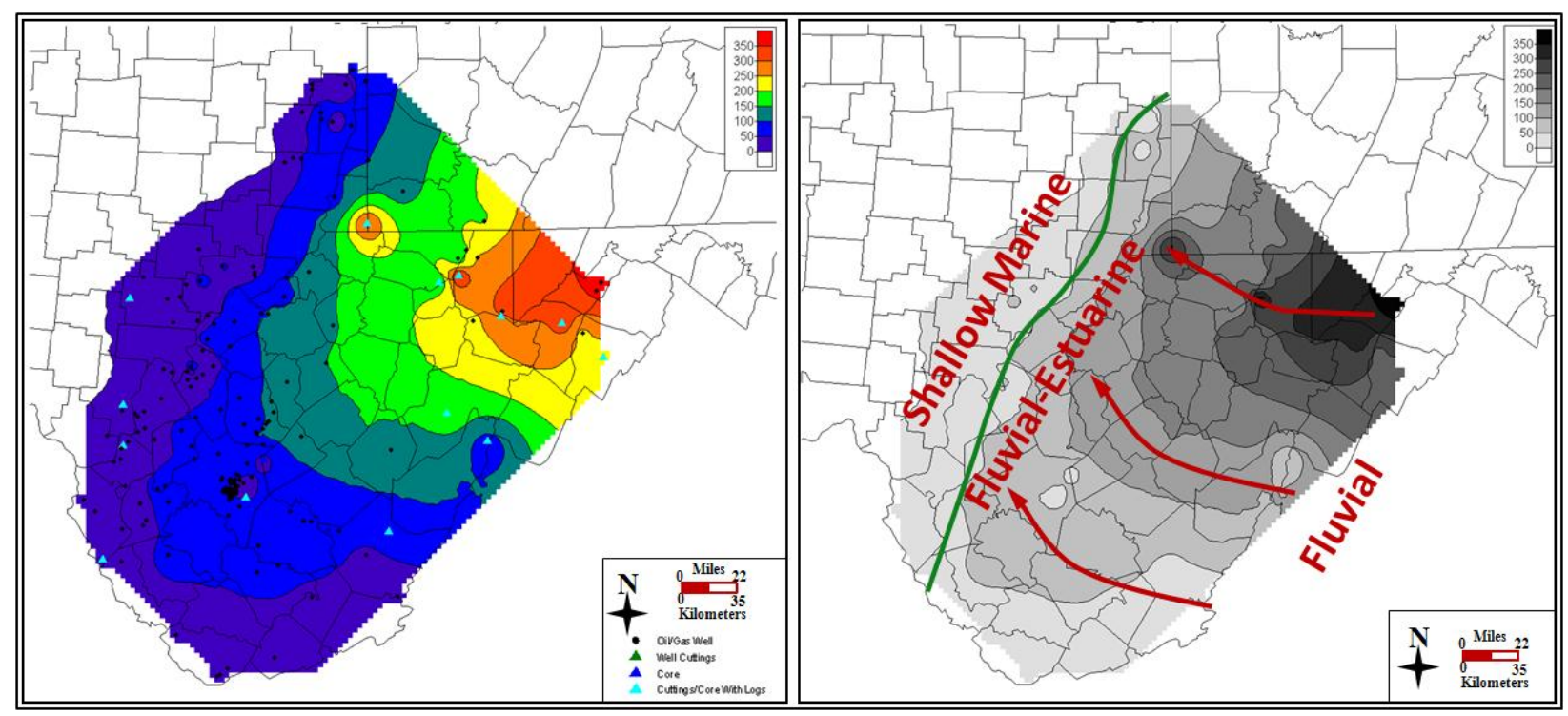

Figure 26: Left: Thickness map of the RST. Right: Interpreted depositional environments of the upper member.

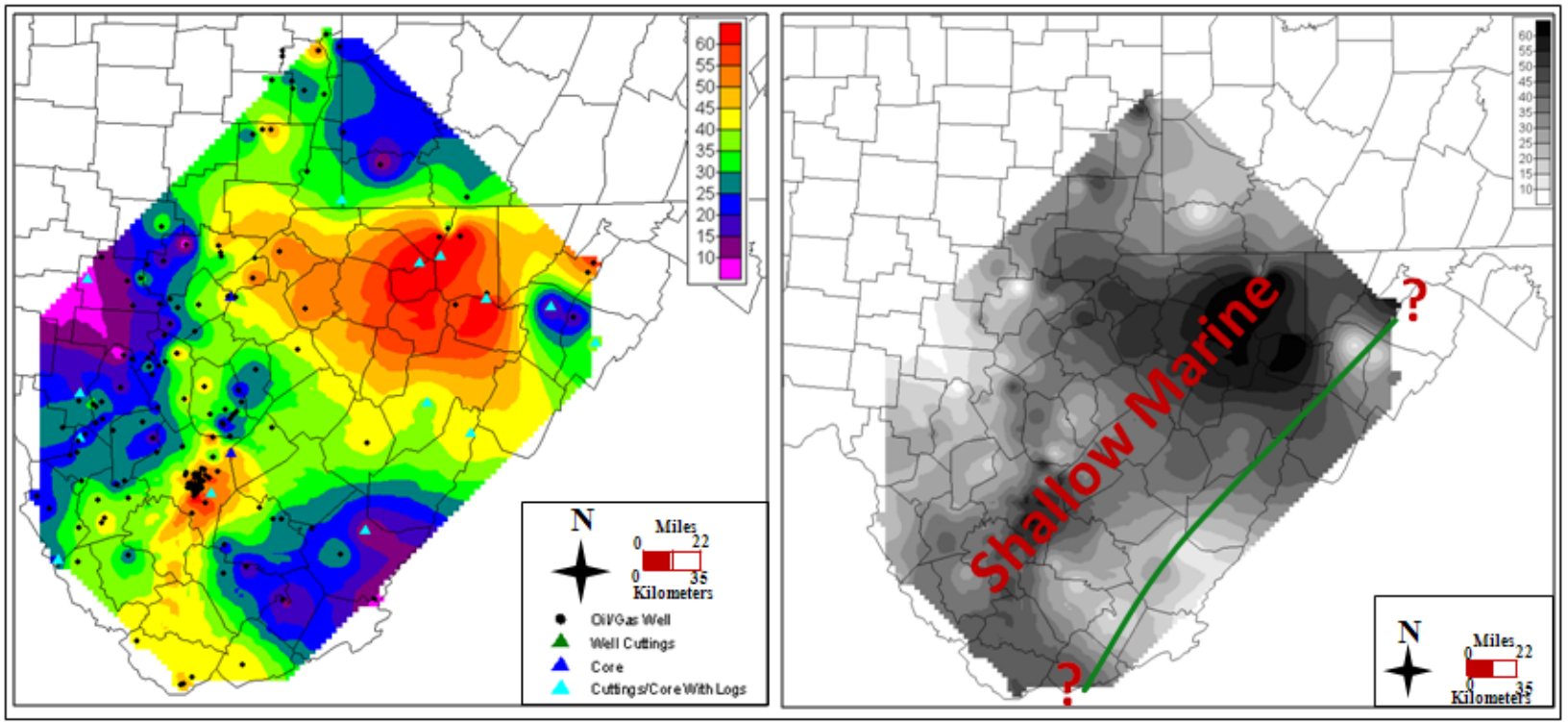

Figure 27: Interpreted depositional environment of the upper member after rise in sea-level.

\section{Gross Tuscarora Sandstone and Rose Hill Formation Isopach Maps}

Using 180 wells, a gross thickness map of the Tuscarora Sandstone was constructed.

Thickness values range in from 51 - 665 feet (15.5 - 203 meters) with a mean thickness of 198 feet (60.4 meters) (Figure 28). The thickest interval occurs in the northeast region near the structural front of the study area where it exceeds 600 feet (182.9 meters). These thick deposits are interpreted as accumulating in the proximal foredeep where subsidence had created high accommodation due to thrusting. To the west-southwest, away from thrusting and subsidence in 
the distal foreland basin, the unit thins significantly, sometimes to values less than 100 feet $(30.5$ meters).

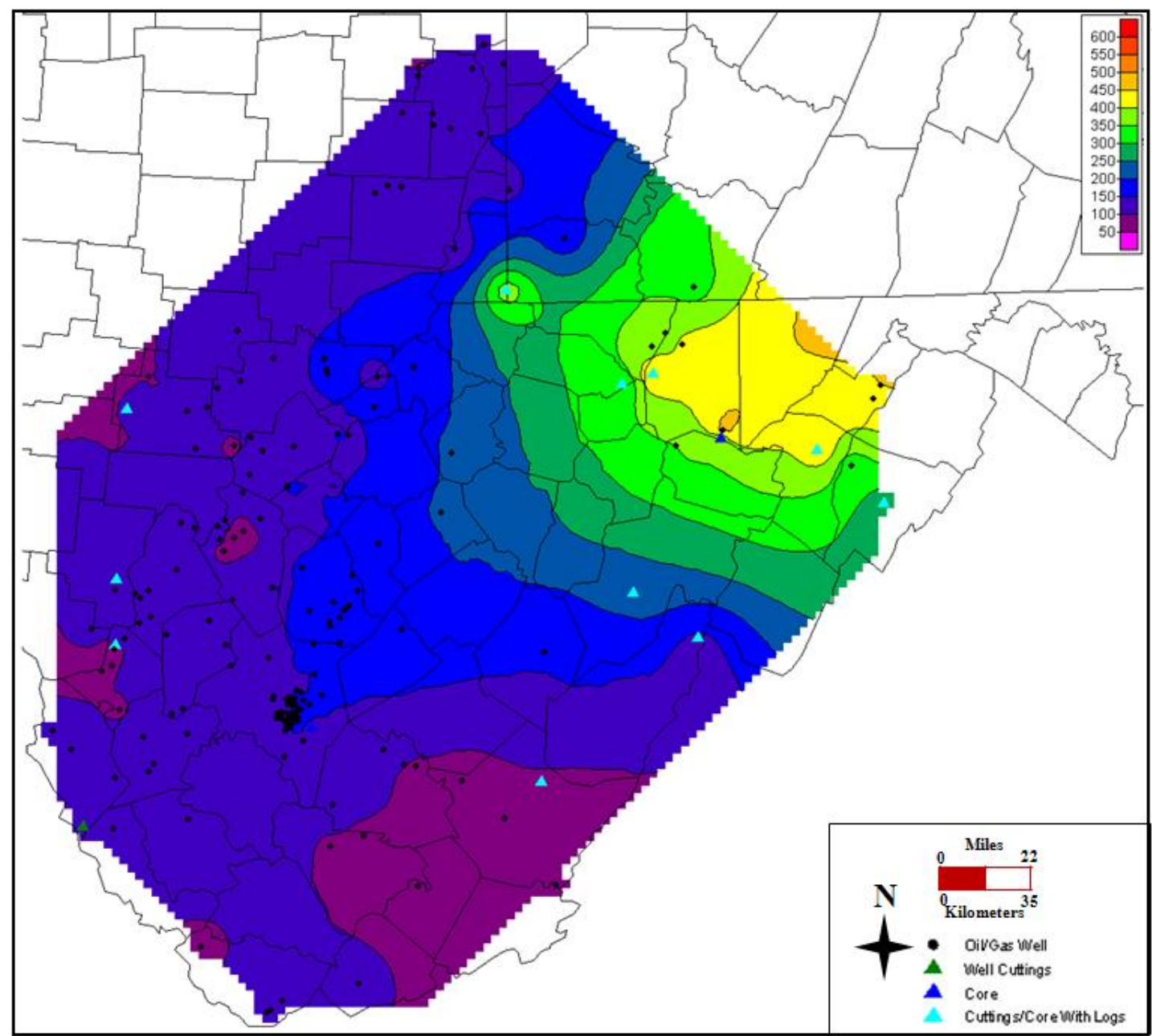

Figure 28: Gross thickness map of the Tuscarora Sandstone. The formation has a thickness trend in the northeast region with significant thinning to the east/southeast. The thickness trend in the northeast is located at the structural front may cause the deposits to be thicker than they actually are.

Although the overlying Rose Hill Formation was not evaluated in this study, it is an integral component for CCS, acting as a seal for the injected $\mathrm{CO}_{2}$. This isopach was calculated from the top of the Rose Hill Formation to the top of the Tuscarora Sandstone. The thickness ranges from approximately 200 to 888 feet (61 to 271 meters) (Figure 29).

The stratigraphic variability along strike may be explained by variations that occur in fold-thrust belts (Macedo and Marshak, 1999). Fold and thrust belts are commonly characterized along their margins by salients and recesses; in this study such features are the Pennsylvania 
salient and Virginia promontory. The thickness trends of all three members in the northeast region of the study area are interpreted to be related to the amount of accommodation space created in the Pennsylvania salient. To the south/southwest in the Virginia recess, the thinner successions of strata can be explained by decreased subsidence (Castle, 2001a,b).

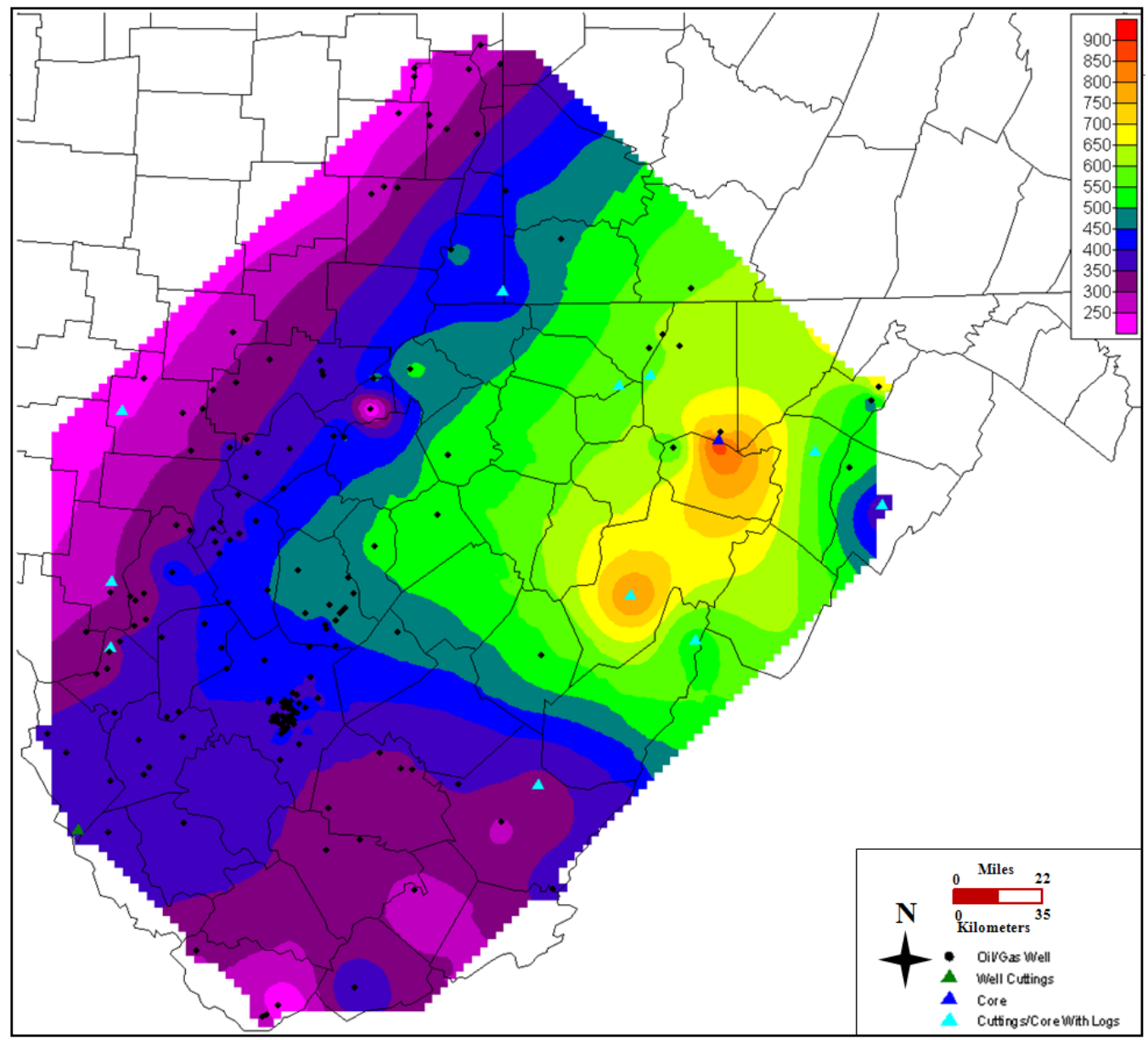

Figure 29: Isopach map of the overlying Rose Hill Formation. This formation is thickest in the eastern region of the state and thins to the east.

\section{SEQUENCE STRATIGRAPHY}

\subsection{Discussion on Stratigraphic Surfaces and Sequence Stratigraphy}

A critical step in a reservoir characterization is the construction of the sequence stratigraphic framework. Sequence stratigraphy is "the subdivision of the stratigraphic succession into sequences which are defined as stratigraphic units bounded by unconformities 
and their correlative conformities" (Embry and Johannessen 1992, p. 124). This application can be useful to interpret the depositional origin and predict the heterogeneity, extent, and character of lithofacies. Within the Appalachian basin previous evaluations of Lower Silurian strata have placed the strata into a stratigraphic framework (i.e., Brett et al., 1990; Castle, 1998; Ryder, 2000; Hettinger, 2001).

The sequence stratigraphic model used in this study is the transgressive-regressive (T-R) model developed by Embry and Johannessen (1992), as an alternative to the depositional and genetic stratigraphic sequence models. The T-R stratigraphic model is similar to the depositional sequence model, which is bounded by subaerial unconformities on the basin margin and by the maximum regressive surface (MRS) seaward; however, a main difference between the T-R model and the depositional sequence model is the elimination of the correlative conformity, which in shallow-marine successions may be difficult to recognize. The equivalent to the correlative conformity is recognized as the MRS, which has an advantage of being delineated in shallow-water settings on almost any type of subsurface data (Catuneanu, 2006). Embry and Johannessen (1992) object to the use of the maximum flooding surface as sequence boundaries used in the genetic stratigraphic sequence because major depositional or tectonic shifts are usually observed across the subaerial unconformity.

Several significant surfaces are recognized within a T-R sequence. The MRS occurs at the base of the transgressive systems tract, separating prograding strata below from retrograding strata above. This change from progradation to retrogradation occurs during a base-level rise at the shoreline when the increasing rate of base level rise outpaces the sedimentation rates. (Figure 30). Strata that show a shallowing upward pattern during the previous regression will now show a deepening upward trend (Embry, 2002). 
The maximum flooding surface (MFS) terminates the TST and commences the regressive systems tract (RST). This surface is equivalent to the maximum flooding surface defined by Posamentier et al. (1988), that is, a surface that marks the change from shoreline retrogradation to subsequent progradation, which occurs during a rise in base-level. The equivalent strata of the highstand and lowstand systems tract are placed in the regressive systems tract. This surface is usually confined to marine strata and it may be either abrupt or within a gradational interval (Embry, 2002). The surface is not found within terrestrial strata because it is replaced by a subaerial unconformity.

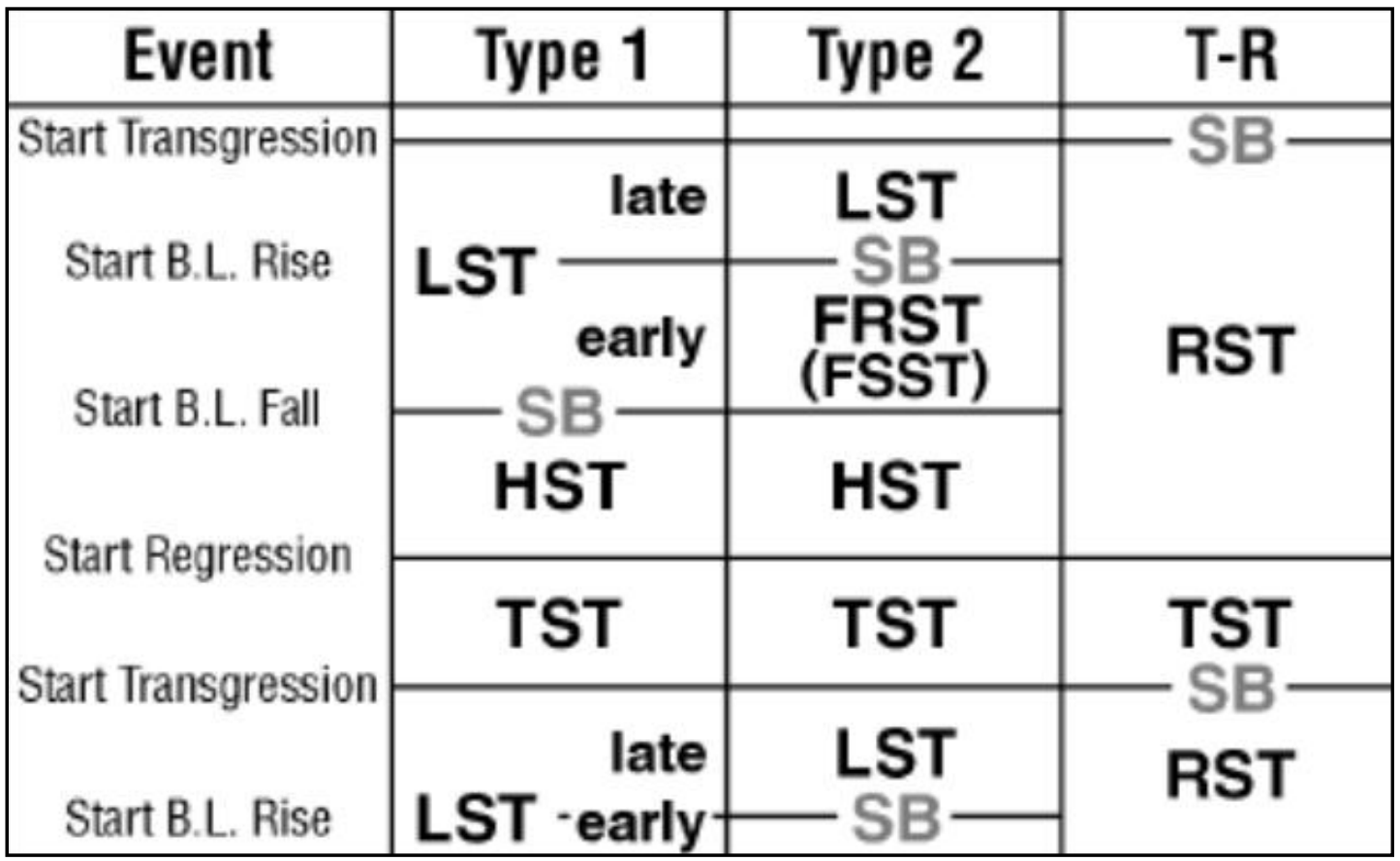

Figure 30: Chart comparing and contrasting systems tracts of the T-R model to the type-1 and type-2 depositional sequences (B.L: base level; LST: lowstand systems tract; TST: transgressive systems tract; HST: highstand systems tract; FRST: forced regressive systems tract; SB: sequence boundary) (From Embry, 2002).

The succession of strata in this study is divided into one entire T-R sequence and the initial transgression of a second sequence. At the base of the Tuscarora Sandstone is the regional Cherokee unconformity truncating the Juniata Formation (Figure 7). On wireline logs, this unconformity is interpreted from a sharp contact separating the lower member with the underlying Juniata Formation (Figure 5a and 7). This unconformity is attributed to a 
combination of lowering of sea level and tectonic influence at the time of the OrdovicianSilurian boundary; a discussion of this unconformity is presented earlier in this chapter (Wheeler, 1963; Dennison and Head, 1975). When putting Lower Silurian strata into a stratigraphic framework several authors recognized this unconformity as a sequence boundary (Brett et al., 1990; Castle, 1998; Ryder, 2000; Hettinger 2001).

The transgressive systems tract is positioned above the basal unconformity and below the maximum flooding surface (Figure 30). During this sequence deposition of the lower member and middle member is attributed to eustasy as well as tectonic influence due to deformational loading causing rapid subsidence (Ettensohn, 2002). In southern Ontario a transgressive surface is interpreted from an abrupt contact between the upper and lower subdivisions of the Whirlpool Sandstone in outcrop (Cheel and Middleton, 1993). Without a corresponding core MRS 1 is difficult to assign a type log; however, a small increase in the gamma ray above the basal unconformity in most wells is interpreted to mark the onset of transgression (Figure 31). Upwards, there sometimes is a distinct fining-upward sequence interpreted from an increasing gamma-ray response caused by a rise in sea-level (Figure 5a and 5c).

A maximum flooding surface (MFS 1) characterized by high gamma ray values is placed in the middle member to reflect fine-grained sediments deposited during sea-level transgression. A MFS is interpreted in the lower Cabot Head Shale and Power Glen Shale and is placed at the maximum gamma-ray response (Castle, 1998; Hettinger, 2001).

The strata above MFS 1 and below the second sequence boundary are placed in the RST. From the maximum flooding surface, the upper member and its equivalents were placed in the highstand systems tract (Castle, 1998; Hettinger, 2001). Castle's (1998) highstand systems tract differs slightly from Hettinger's interpretation in terms of picking the confining sequence 
boundary: Castle places the top at a marine flooding surface while Hettinger places the top at a regional unconformity.

A coarsening upward succession observed in core and gamma-ray logs is indicative local sedimentation rate exceeding relative sea-level rise. The thick stacking patterns in log show aggradation of deposits as the rate of sedimentation kept pace with the rise in sea-level.

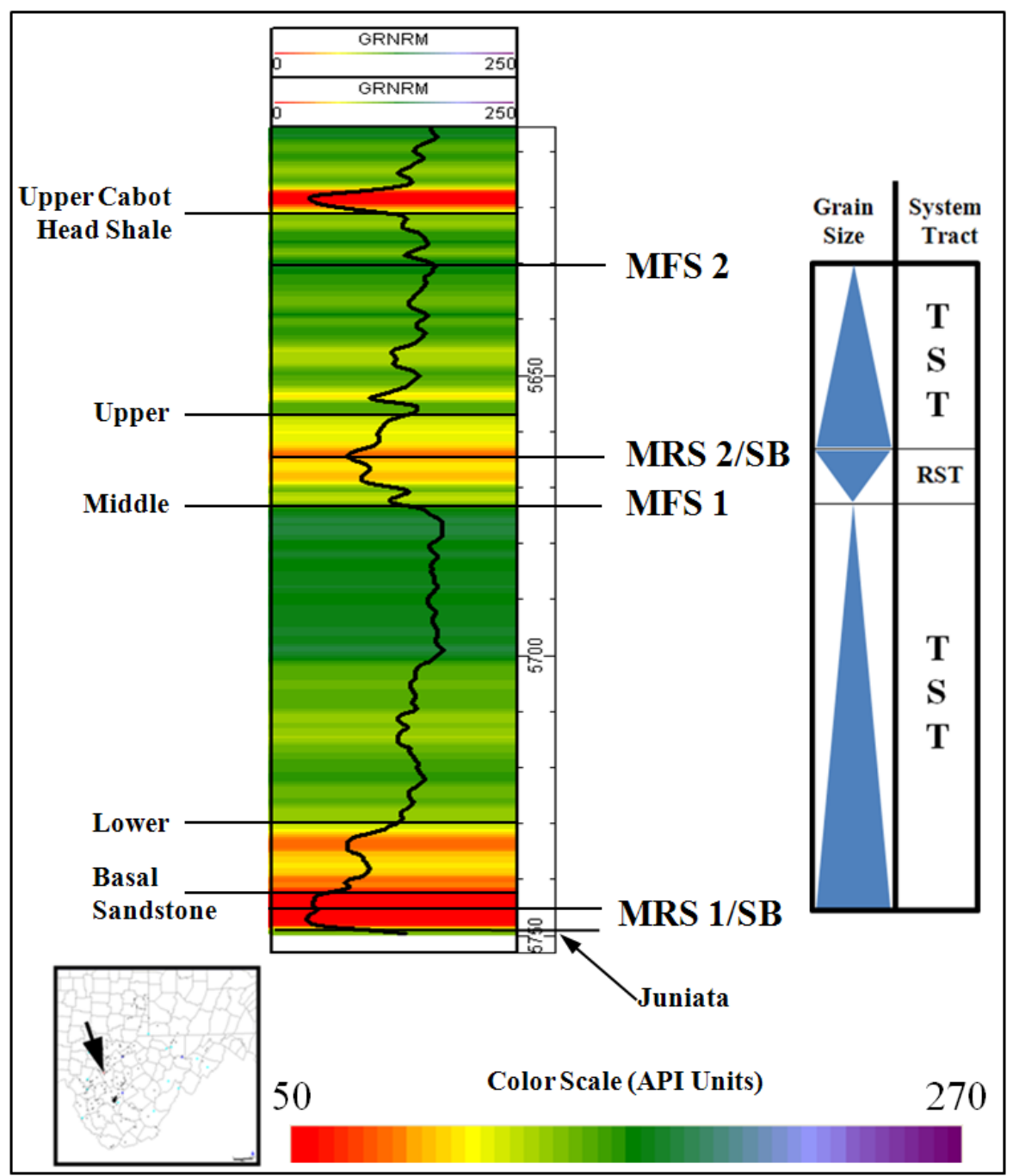

Figure 31: Interpreted systems tracts and relation to grain size in geophysical logs from Jackson County (API\# 470350145628).

Away from the proximal foreland, the thinner members of the upper member show a coarsening upward sequence overlain by a fining upward sequence. It is possible that this may be the unconformity recognized by Hettinger (2001). In shallow marine regimes the MRS is typically 
recognized at the top of coarsening-upward deposits. The MRS may or may not be associated with sandstone/shale lithological contrasts, corresponding to a sandstone/shale contact that suggests rapid transgression. To the east in the study area, where there is a sharp sandstone/shale contact, the MRS is placed at this position.

Typically, above MFS 1 there is a coarsening upward sequence, as the value of the gamma ray log decreases. Above this sequence is the onset of a fining-upward sequence. MRS 2 is placed at the contact of the coarsening-upward and fining-upward sequence. In some wells there were stacked coarsening-upward sequences and MRS 2 was placed at the top of these aggradational deposits.

The position of the upper sequence boundary is debatable. It is possible that MRS 2 is an unconformity (Dorsch et al., 1994; Hettinger, 2001). However, a lack of physical evidence in the subsurface to the west makes this difficult to justify. Hettinger (2001) proposed an unconformity (unconformity 3) within the upper member caused by paleovalley incision during a fall in eustatic sea-level based on irregular truncation observed in well logs. This unconformity may be correlative with the "Tuscarora" unconformity in southern West Virginia; however there may be differences between these unconformities. Firstly, along strike in the Valley and Ridge province the presence and location of this unconformity varies and cannot be easily correlated. The strata above the "Tuscarora" unconformity are interpreted as lower shoreface to nearshore environments (Dorsch et al., 1994) while in Pennsylvania and northern West Virginia, strata is interpreted as being deposited in a fluvial-estuarine environment (Hettinger, 2001; Ryder, 2006). Another difference in these unconformities is the cause; the "Tuscarora" unconformity is interpreted as being tectonically influenced while unconformity 3 is attributed to a fall in sea level (Hettinger, 2001; Ryder, 2006). 
A second sequence boundary has been proposed near the top of the Tuscarora Sandstone. Several authors have identified an Aeronian aged unconformity that is overlain by hematitic shale, limestone, dolostone, and phosphate in the overlying Rose Hill Formation/Clinton Group (Goodman and Brett, 1994; Brett et al., 1998; Castle, 2001). A thin lag deposit of bluish-gray weathered phosphatic nodules is observed in northeast Ohio and central Pennsylvania at the upper contact of the Tuscarora Sandstone and Rose Hill Formation is interpreted as a sequence boundary (Brett et al., 1990, 1995, 1998; Castle, 2001).

Taking into consideration the lack of available core data and the lack of a distinct lithologic marker, the second sequence boundary is placed at the contact between the coarsening upward and fining upward sequences marking the end of a regression and the start of the ensuing transgression. A second maximum flooding surface is placed at the top of a fining-upward sequence recognized in the overlying upper Cabot Head Shale.

\subsection{Regional correlations of significant stratigraphic surfaces and systems tracts}

After the stratigraphic surfaces have been defined, they were regionally correlated across the study area using the previous defined criteria to construct ten cross-sections ( 6 dip-oriented, 4 strike-oriented) (Figures 32-42). 


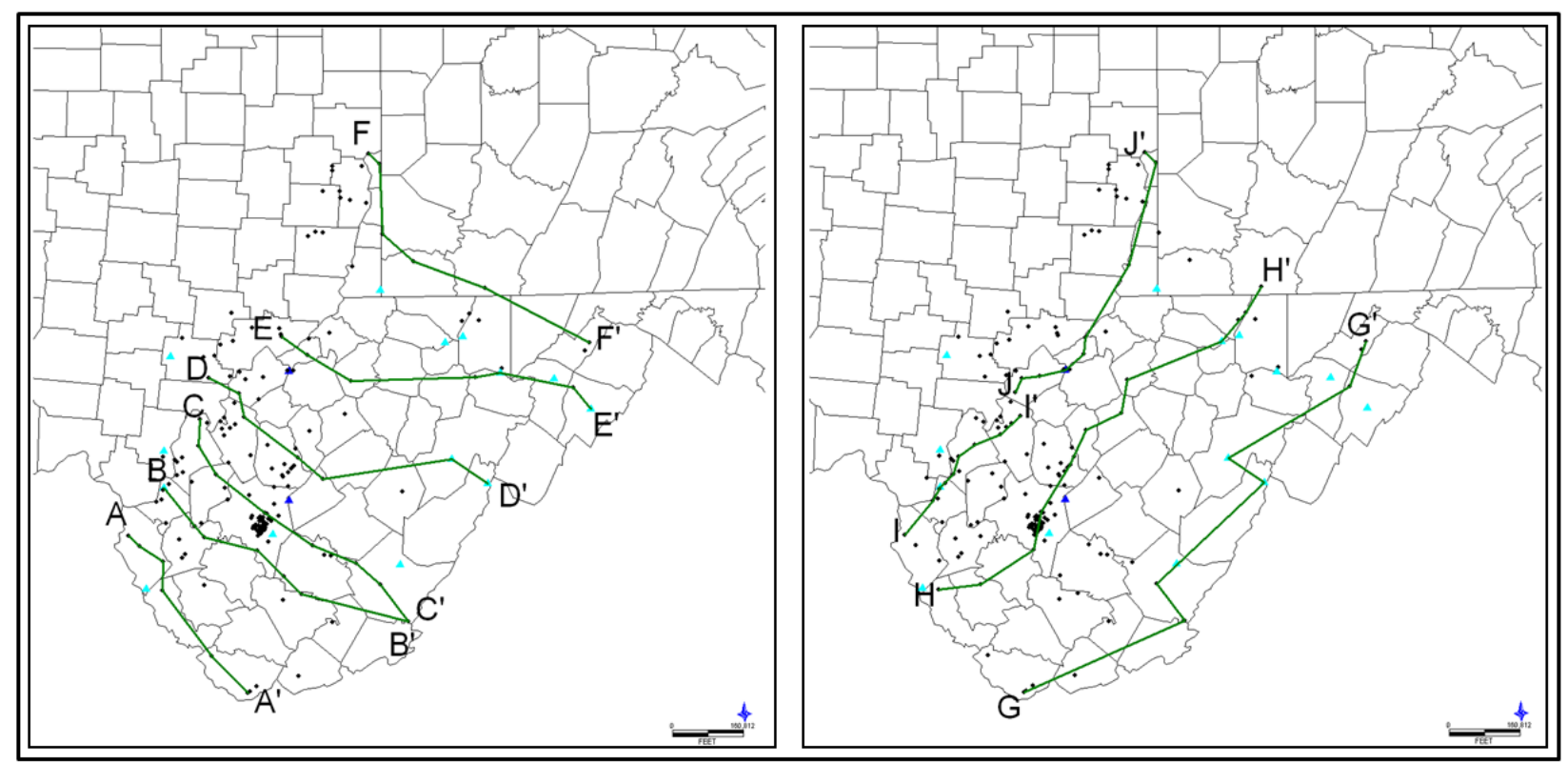

Figure 32: Orientation of 6 along-dip and 4 along-strike lines of section

The general pattern of the TST 1 in dip-oriented cross-sections shows an overall trangression to the east (Figures 33-39). The carbonate and sandstone beds of the lower member and dark shale of the middle member within TST 1 are thickest in the west and generally thin to the east, interpreted as a result of a facies change a lack of accommodation (Figures 33-39). A thickness anomaly occurs in the northeast possibly as a result of high accommodation or bed thickening caused by thrusting (Figure 39). Within TST 1, channel features of the lower member are observed along-dip and along-strike in cross-sectional view (Figures 33, 37 and 41).

Landward, placement of the maximum flooding surface is difficult; however, small features such as fining-upward sequences in east are interpreted to represent maximum flooding (Figure 35).

The RST contains the uppermost strata of the middle member and the lower portion of the upper member. In the cross-sections thick progradational strata of the RST occur in the east and increase in thickness along-strike and along-dip to the north, especially the northeast region (Figures 34-40). This change in thickness is interpreted to occur as a result of high amounts of available accommodation and high rates of sedimentation in the proximal foreland basin. This 
thickening in the northeast may be the result of accommodation created in the area of the Pennsylvania salient (Castle, 2001a, b). To the west and southwest the RST thins, interpreted as lateral progradation that occurred as a result of overfilling in the proximal foreland (Figures 3440). Within the RST the amount of shale content is low in the east and an increase in shale beds occurs to the west, possibly as a result of an increase in marine-energy. Also, along-strike in the western-most cross-sections, thickness is relatively consistent and there appears to be occurrences of stacked and isolated channels, possibly estuarine in origin (Figure 41).

TST 2 is the initial systems tract of the second sequence, which includes the strata between the MRS 2 and MFS 2. In cross-section, TST 2 shows a similar thickness trend to TST1, as it is thicker in the west and thins to the east, except for in the northeast, where a thickness anomaly is likely a result of increased accommodation (Figures 37-40). Different from TST 1 is the position of the thickness trend of TST 2; in cross-section the thicker intervals appear to occur towards the center of the study area (Figure 40). To the east above the MFS 2, progradation is observed, which is interpreted to be the start of a second regressive systems tract (Figures 33 and 34). TST 2 appears to be a higher order sequence than TST 1.

A useful extension of this study would be the application of the depositional sequence model to the Tuscarora Sandstone. This approach uses a composite sequence boundary that contains a subaerial unconformity and its marine correlative conformity (Catuneanu, 2006). This sequence boundary created during fluvial incision is interpreted at the contact of the lower member and underlying Juniata Formation and the contact of the upper member and middle member where truncation of the underlying shelf deposits occurs (Figure 43). Fluvial-estuarine deposits filling the incised valleys mark a basinward shift in facies along with the overlying shallow-marine parasequences. In the adjacent interfluves, where incision is not as extensive, 
the erosion surface is correlative with a flooding surface; and the overlying shallow marine parasequences overlie soil horizons and/or exposure surfaces (Van Wagoner et al., 1990). 


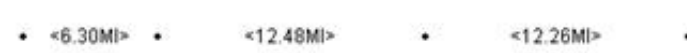

$\times 35.15 \mathrm{ml} \times$

$<22.34 \mathrm{Ml}$

•
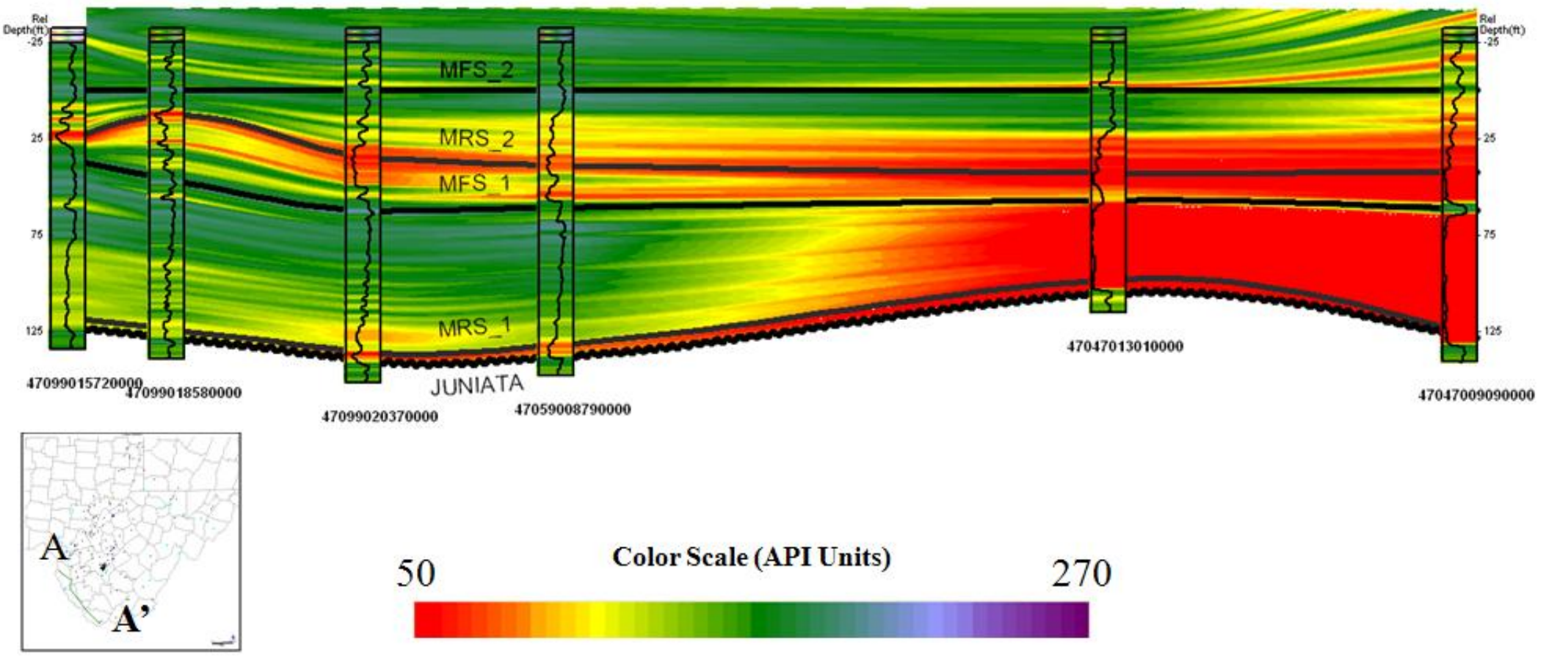

47099020370000

47059008790000

Figure 33: Cross-section A-A' using the second maximum flooding surface (MFS 2) as a datum. A transgression is observed in TST 1 (MRS 1- MFS 1) and an interpreted facies change occurs between MRS 1 and MFS 1from the 4th well from the left to the right. Progradation occurs from MFS 1 to MRS 2 (RST), with thicker

deposits in the east that thin to the west. The RST is overlain by TST 2 of a second sequence, which is interpreted as being a higher order sequence. An overall transgression is interpreted from the MRS 1 to the MFS 2, with a higher order transgression occurring above MRS 2. Progradation occurs above MFS 2 in the east, interpreted as a second RST. 


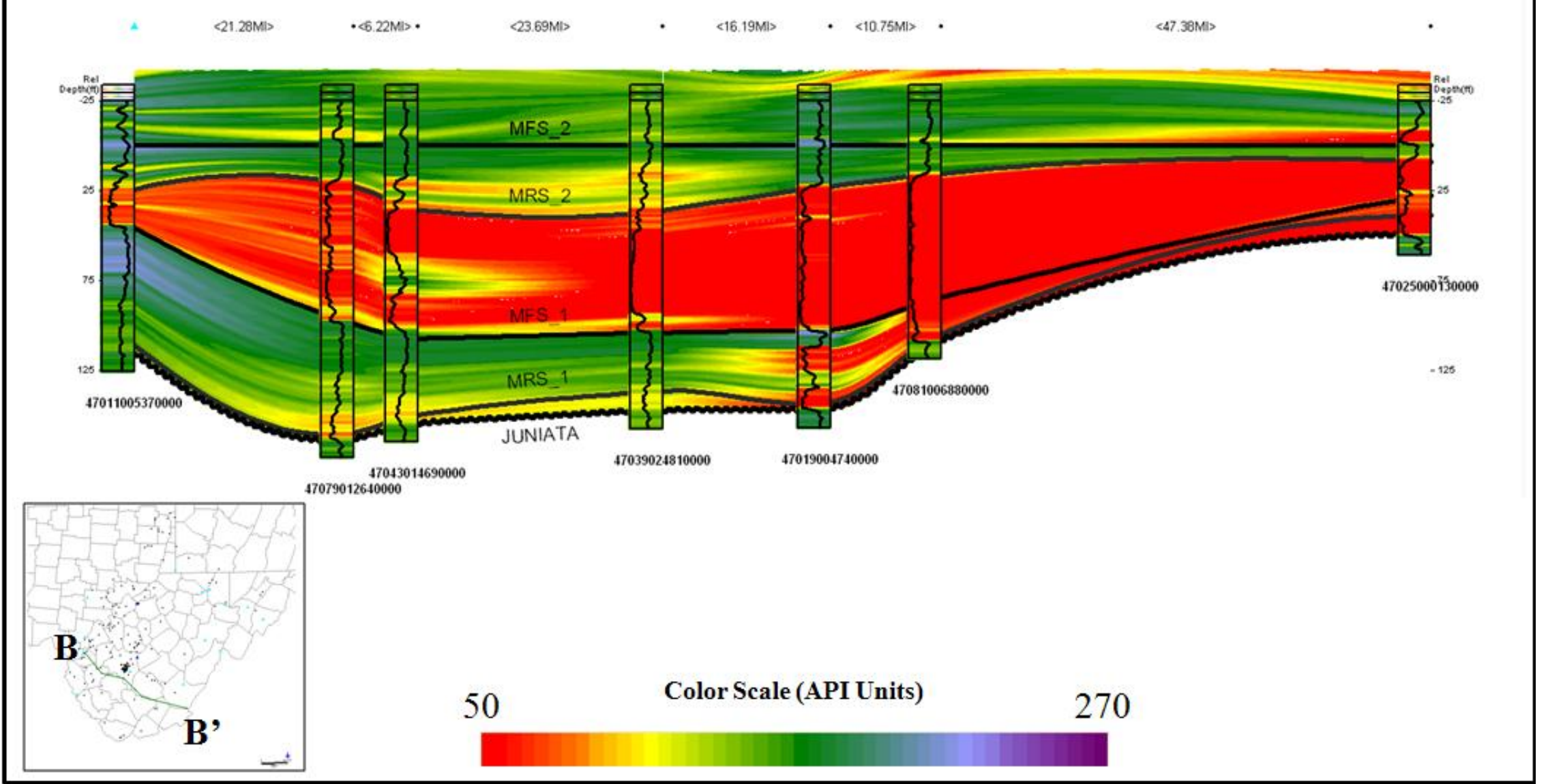

Figure 34: Cross-section B-B' in the southwest with the MFS 2 used as a datum. Similar to Figure 27, a transgression is observed in TST 1 (MRS 1- MFS 1) and it appears a facies change occurs between MRS 1 and MFS 1from the 4th well from the left to the right. Progradation occurs from MRS 1 to MFS 2 (RST), with the thicker deposits in the east that thin to the west. There is also an increase in shale beds to the west. An overall transgression from MRS 1 to MFS 2 is interpreted with a higher order sequence occurring above MRS 2. Note the increase of shale to the west and progradation above the MFS 2 in the east. 


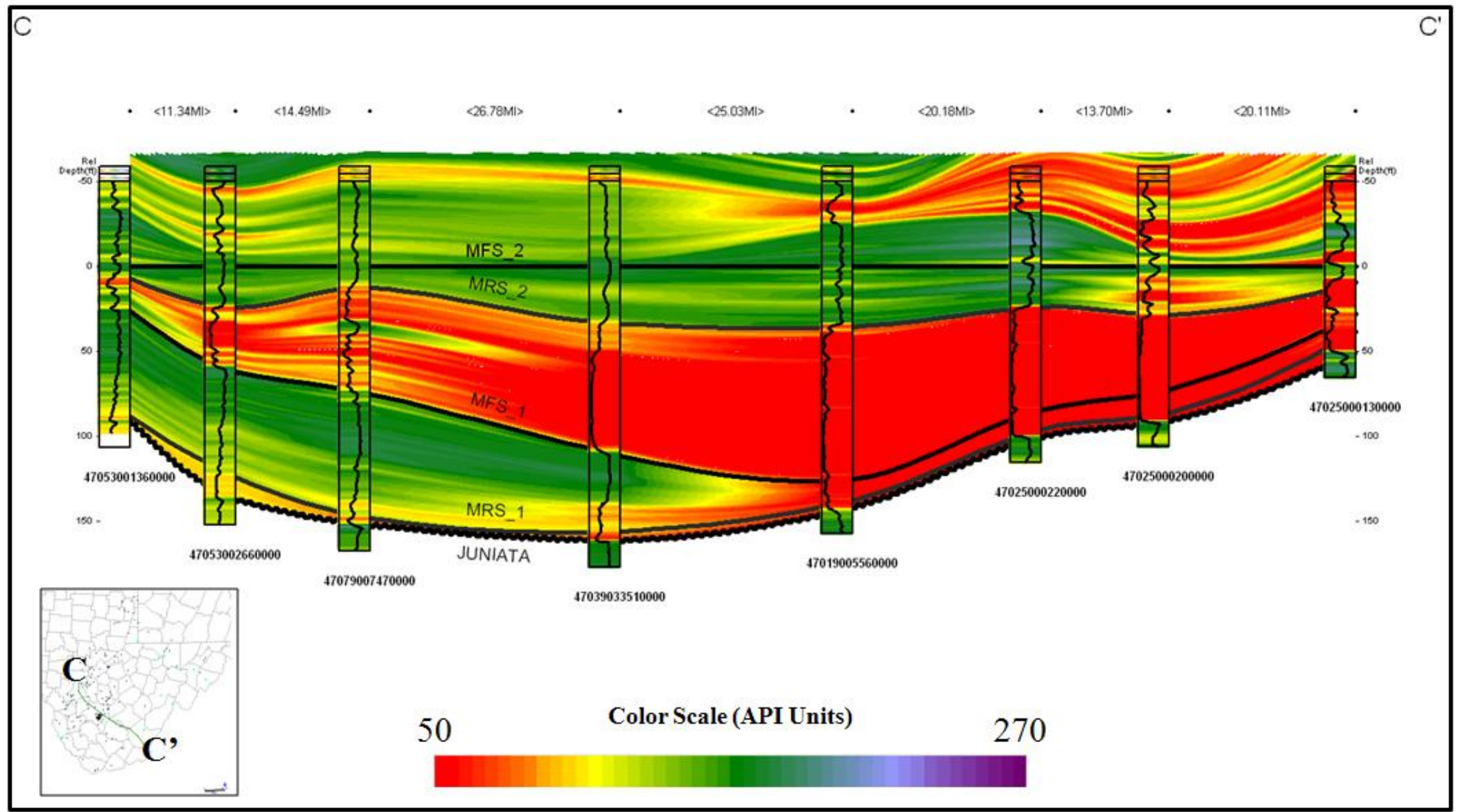

Figure 35: Cross-section C-C' through central West Virginia. A facies change occurs again in TST 1 and these are overlain by the prograding deposits of the RST, which are thickest towards the east. Increased shale beds are observed in the west as well and TST 2 shows a thickening to the east. The thin shale beds occurring at the top of fining-upward sequences in the east are interpreted to represent the landward extent of the MFS 1 


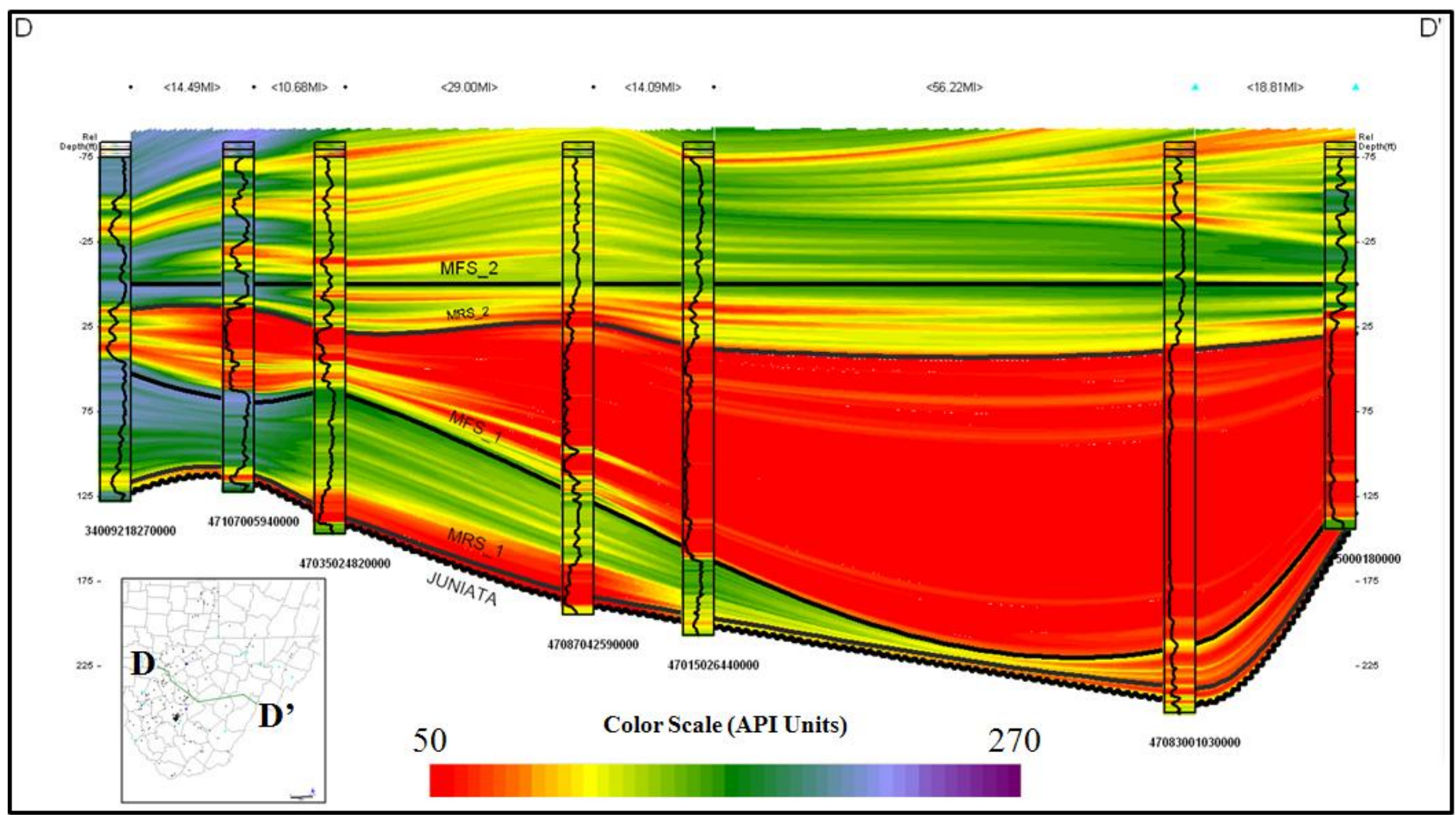

Figure 36: Cross-section D-D' through central West Virginia with the MFS 2 used as a datum. There is rapid increase in the thickness to the east interepreted as a result of an increase in accommodation and thickening due to thrusting. Channel features of the lower member are well displayed in four wells in the west. 


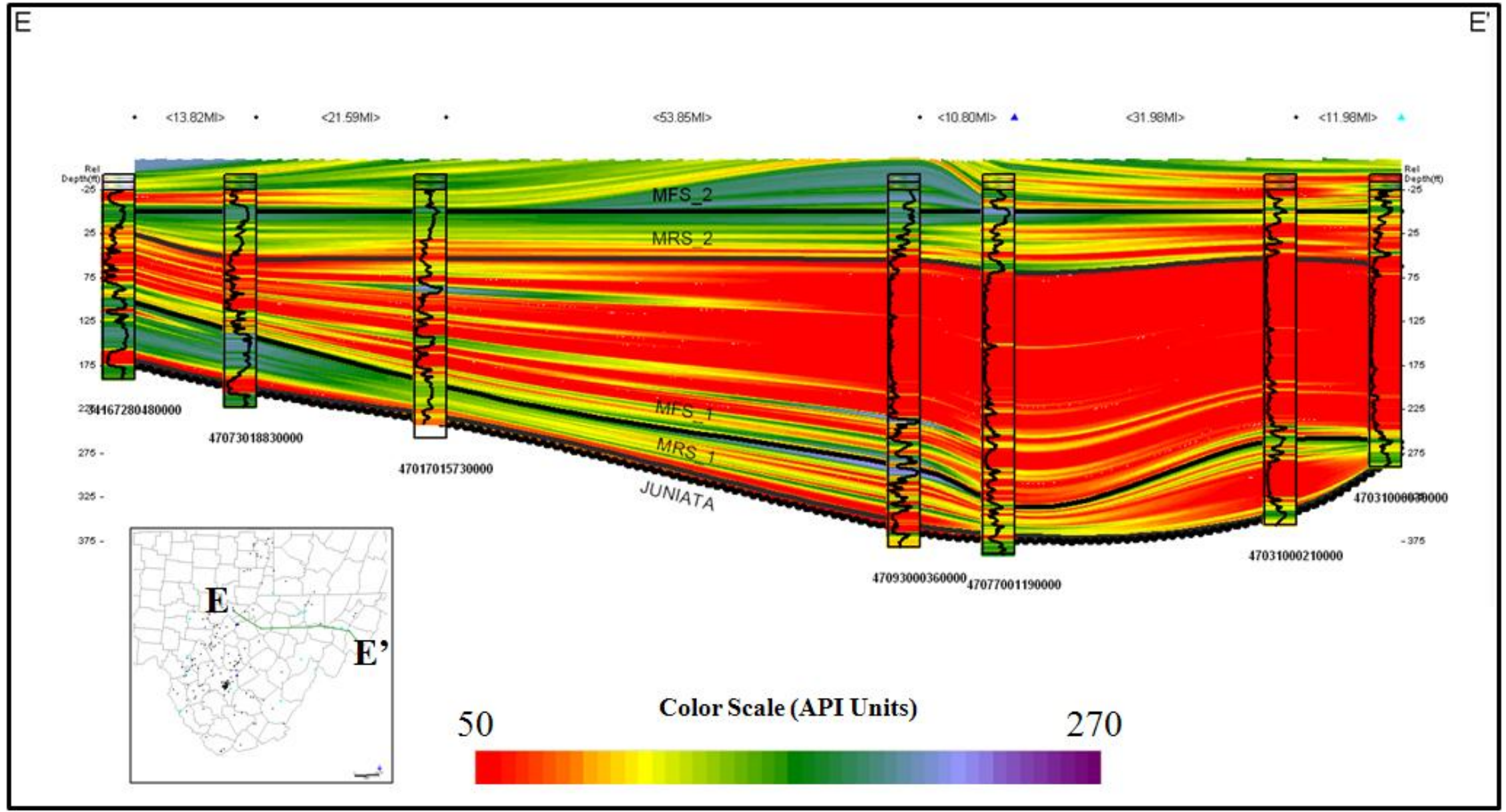

Figure 37: Cross-section E-E' in northern West Virginia with the MFS 2 used as a datum. Again, there is a significant increase in the thickness of the RST in the northeast as well as an increase in shale to the west, possibly indicating an increase in marine energy. 


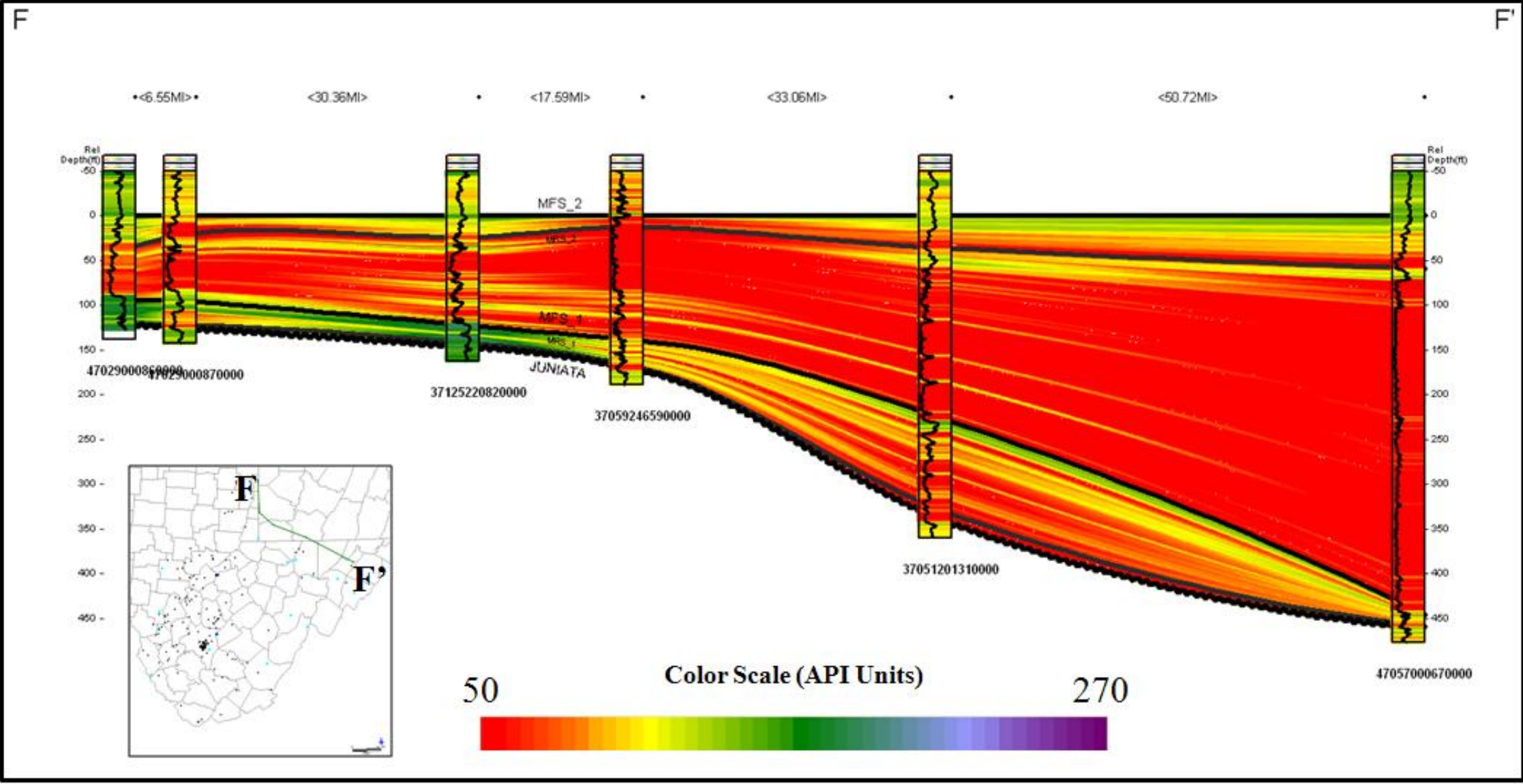

Figure 38: Cross section F-F' in from the northern panhandle to the eastern panhandle with the MFS 2 used as a datum. The amount of shale decreases to the east as well as a thickening, related to an increase in accommodation and thickening in the proximal foreland. 
45 . $59 \mathrm{Ml}$

- $<2.11 \mathrm{M} \gg \cdot$

$63.50 \mathrm{Ml}$

+ <18.81M|> *

$<60.51 \mathrm{MI}$

- $20.55 \mathrm{MI}>$.

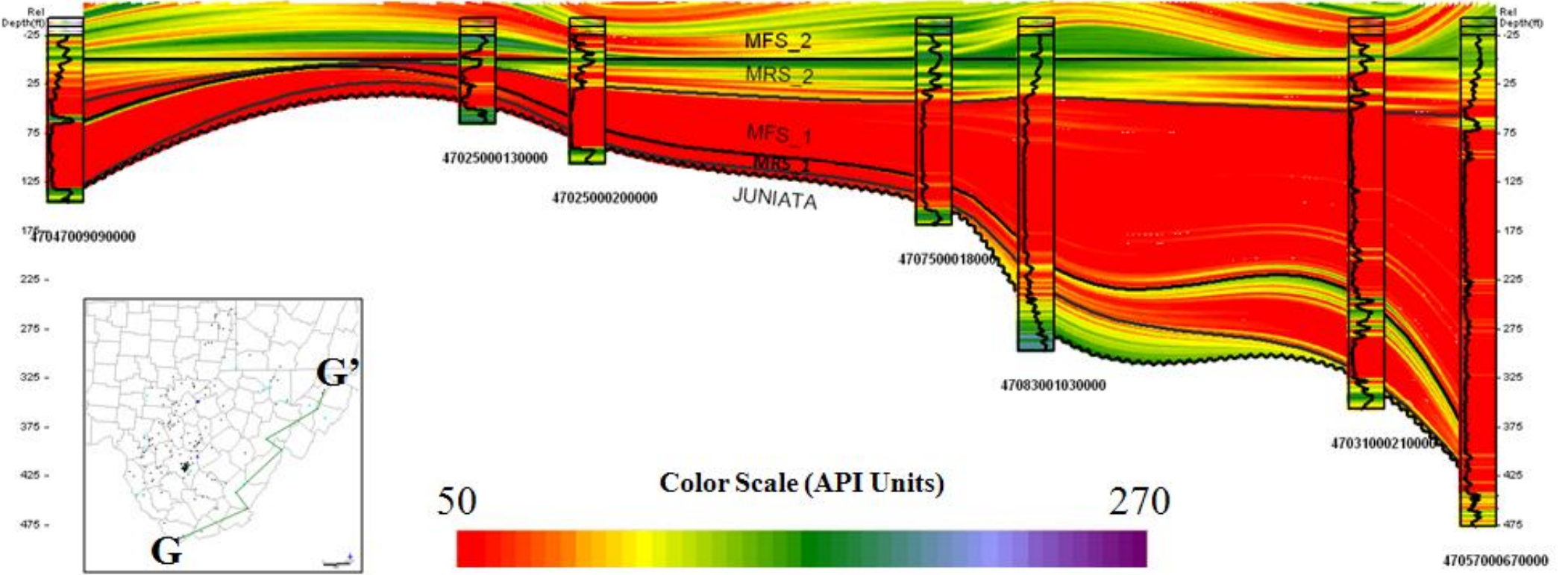

Figure 39: Cross section G-G' along the eastern margin of the study area with the MFS 2 used as a datum. From the southwest to northeast there is a significant thickness change in the RST resulting from increased accommodation and thickening. 


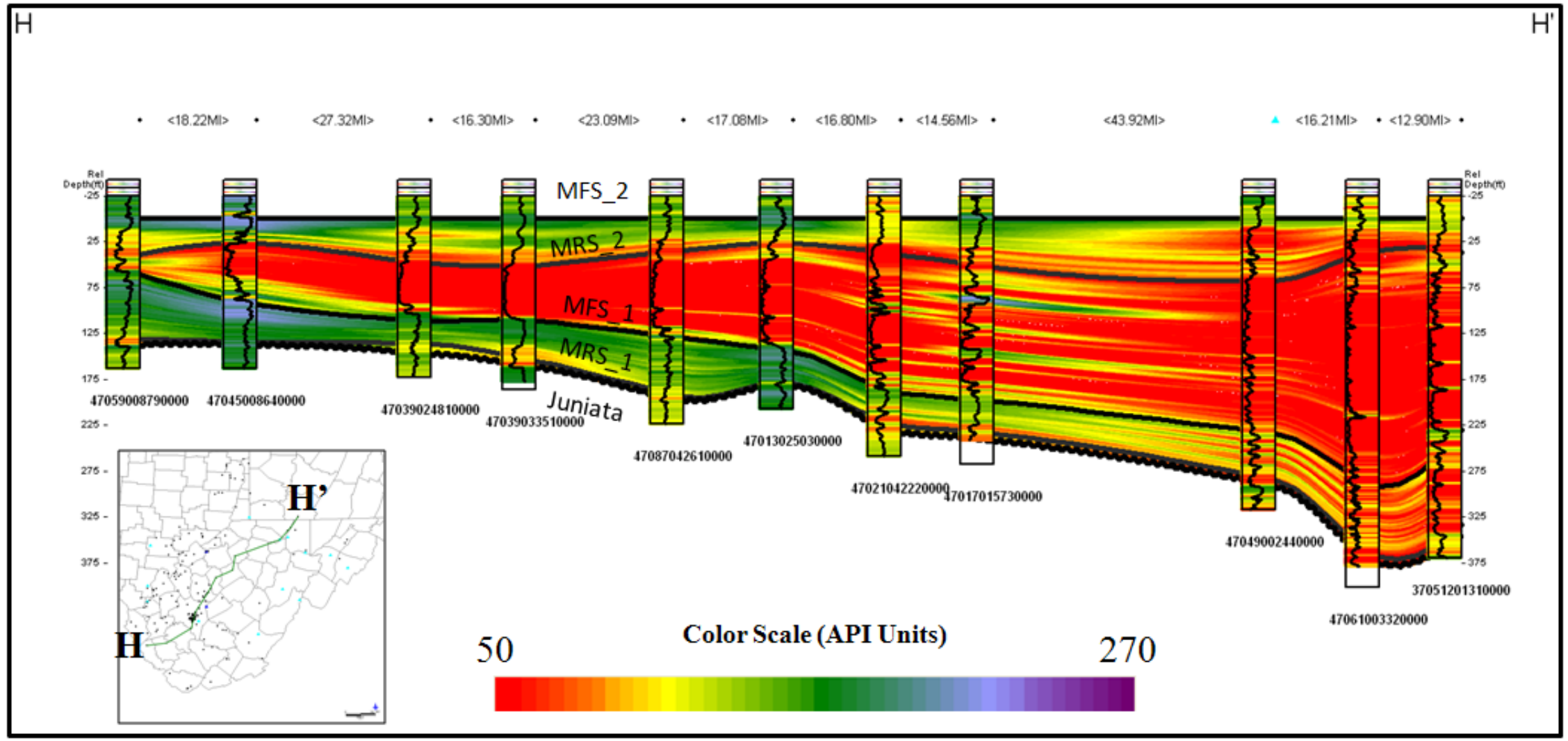

Figure 40: Cross section H-H' through central West Virginia using the MFS 2 as a datum The RST thickens to the north and there is a noticeable increase in the amount of shale within the RST towards the northeast region of the study area, possibly indicating an increase in marine influence. 


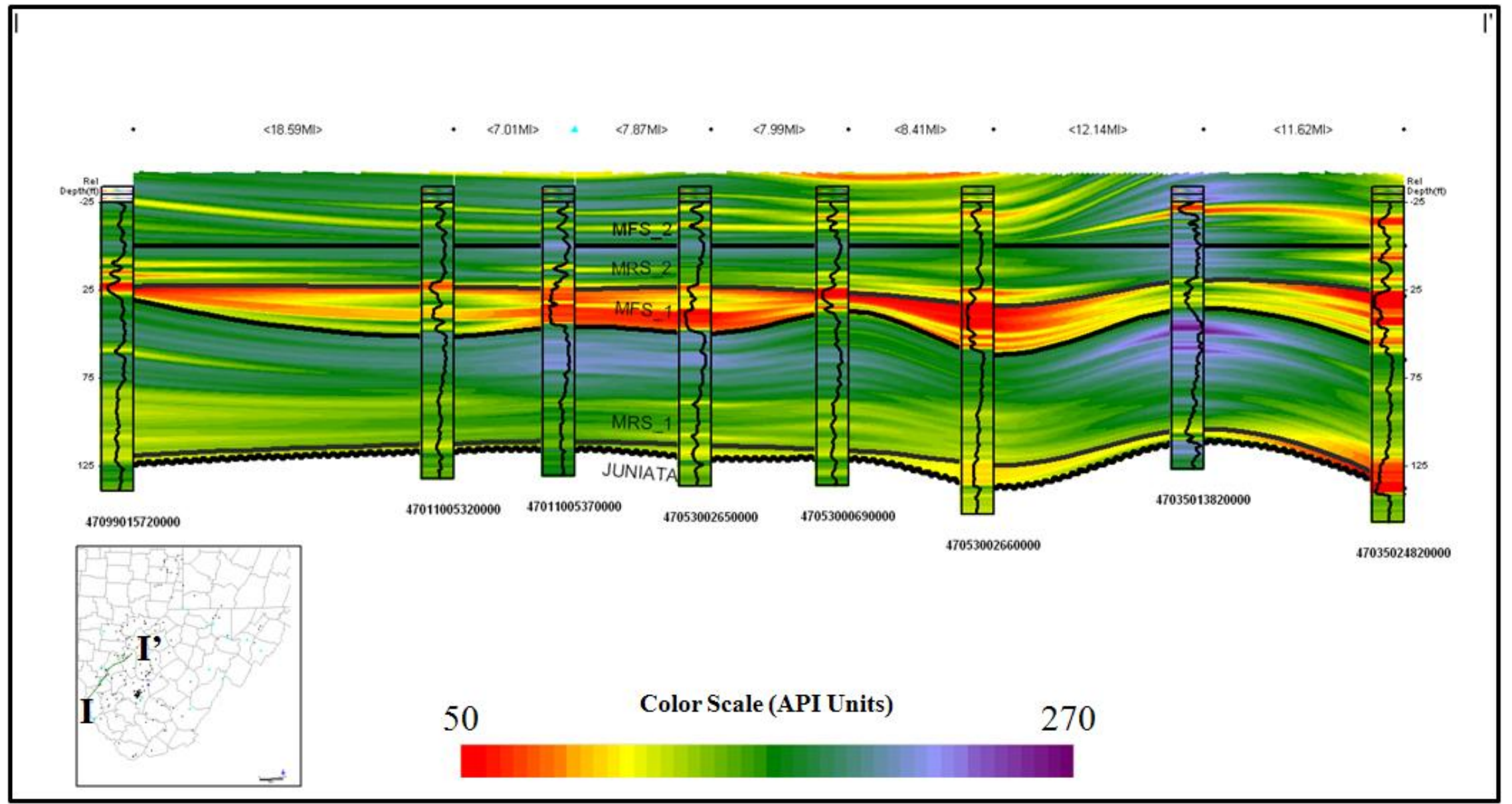

Figure 41: Cross-section I-I' in the southwest region using the MFS 2 as a datum. Thickness of individual systems tracts is relatively consistent along-strike in the west and channel features, possibly estuarine in origin, are interpreted in the upper and lower members (purple). 


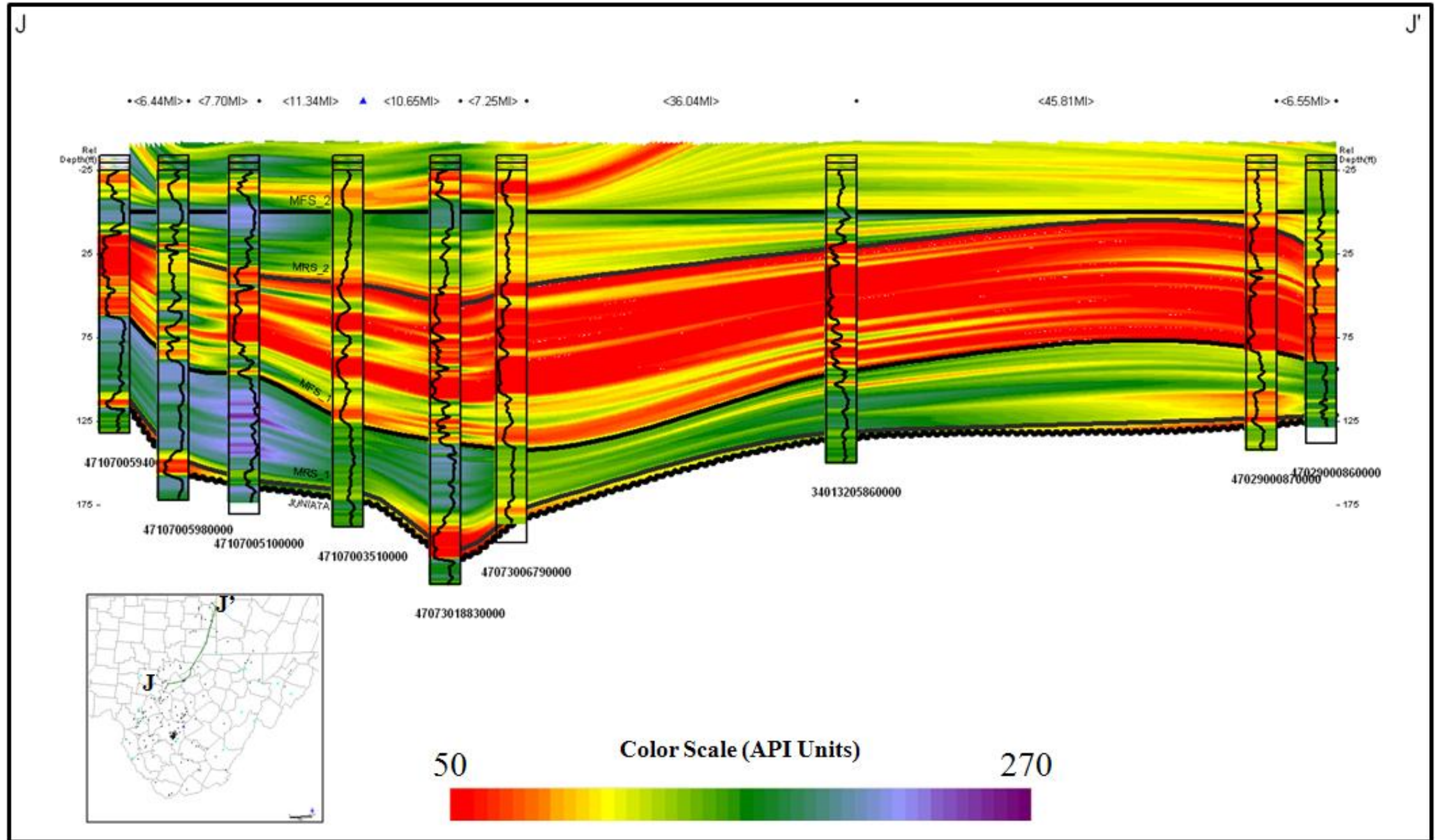

Figure 42: Cross-section J-J' in northwest West Virginia. The thickness of the systems tracts are mostly consistent along-strike. Note the appearance of incised valleys in the lower member of the fifth well from the left and a decrease in shale content in the upper member to the north. 


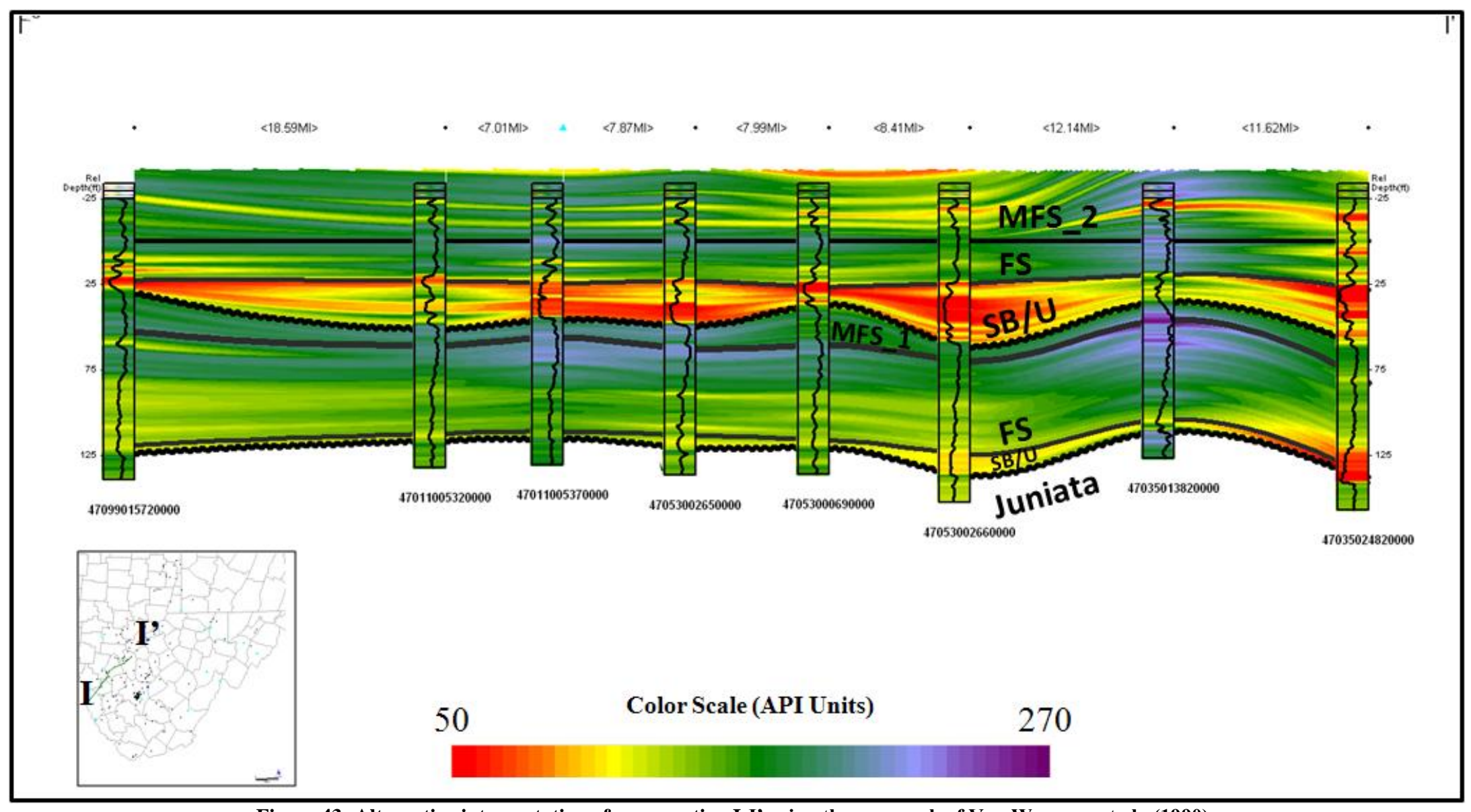

Figure 43: Alternative interpretation of cross section I-I' using the approach of Van Wagoner et al., (1990). 


\subsection{Regional mapping of systems tracts}

TST 1 was mapped using only wells with complete intervals of the Tuscarora Sandstone $(n=117)$; thickness was calculated from the top of MFS 1 to the top of MRS 1 and contains the lower and middle members. TST 1 is thickest to the west and generally thins pattern landward to the east (Figure 44). In the northeast there is a rapid change in thickness interpreted as a result of thickening caused by thrusting; several of these wells were drilled in the cores of anticlines.

Overall, the thickness trend, with the exception of the anomaly in the northeast, trends in a general north to northeast direction.

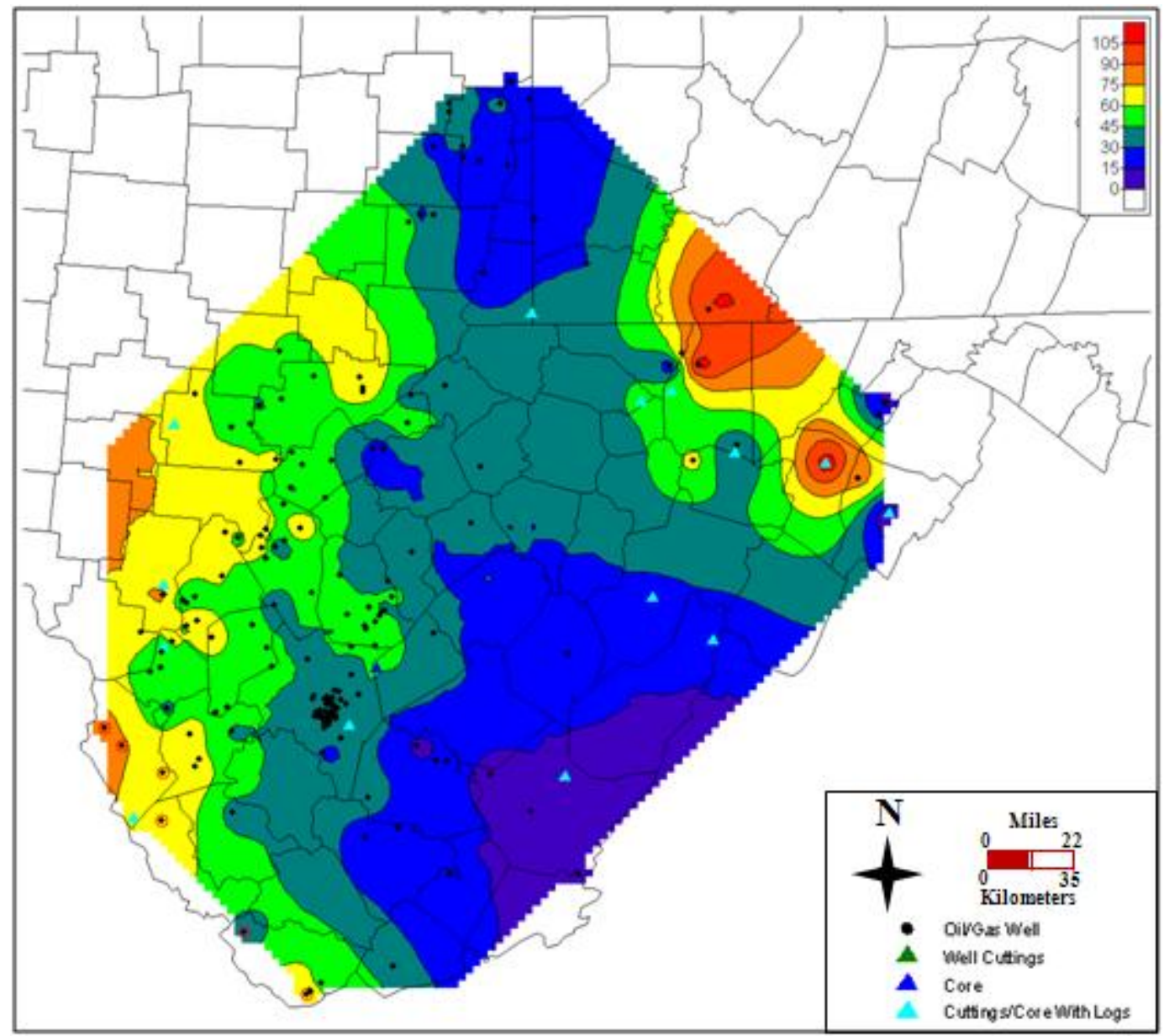

Figure 44: Isopach map of the first transgressive sytems tract (TST 1). TST 1 is thick basinward in the west and thins to the east. There is a thickness trend in the northeast, interpreted to be a feature of increased accommodation available during deposition in the proximal foreland and thickening during thrusting. Overall, there appears to be a thickness trend oriented to north-northeast. 
The RST isopach map was calculated using wells that contained the upper member and intervals of the middle member above MFS 1. The isopach map of the RST shows that the thickest deposits are in the proximal foreland to the east that thin to the west (Figure 45). The thick deposits in the northeast may be a result of two causes. The deposits in the upper member may have been deposited in accommodation created by backward-rotational subsidence caused by thrust loading near the orogen (Castle, 2001a, b). Secondly, thickening may be due to thrusting. During the late stage of orogenic thrust loading, high relief in the source area creates a high rate of sediment supply, trapping coarse detritus in the proximal foreland and as the sediment supply exceeds accommodation in the proximal basin, progradation into the distal foreland ramp occurs (Castle, 2001a, b).

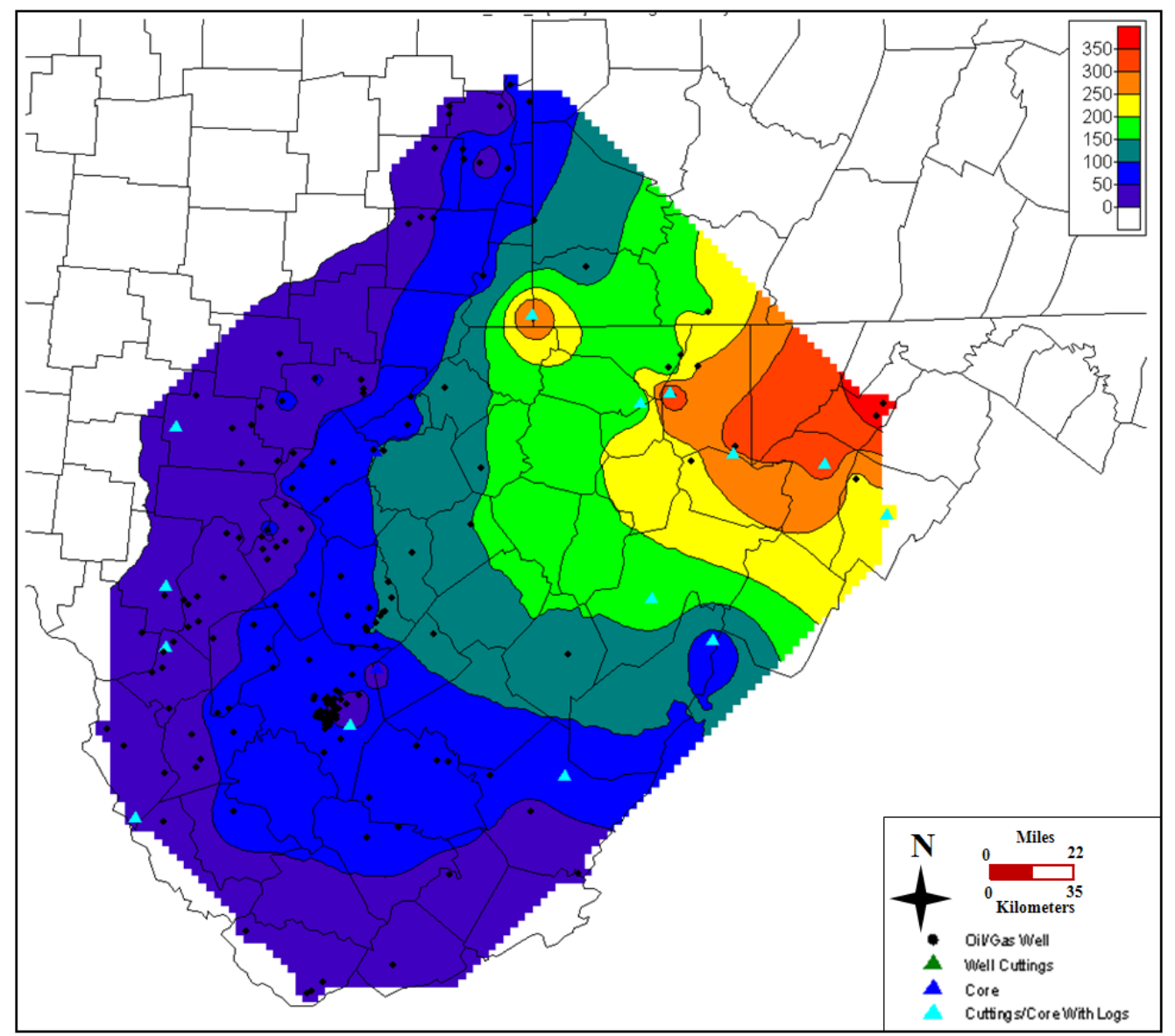

Figure 45: Isopach map of RST. The thicker deposits are in the east in the proximal foreland and thin to the west. The thickest deposits that occur in the northeast were deposited in an area of high accommodation; when this area became overfilled, lateral progradation occurred. 
The isopach map of TST 2 was constructed from the top of MRS 2 to the top of MFS 2 (Figure 46). Similar to the isopach of TST 1, the thickest deposits occur towards the west and there is thinning to the east, with a thickness anomaly in the northeast. The trend of the thickness map also appears to be oriented north to northwest. TST 2 differs from the TST 1 isopach map in the location of the thickness trend. In TST 1 the thickness trend was located farther basinward to the west, while in TST 2 it appears that the thickness trend of TST 1 occurs along strike in the center of the study area. This indicates that the TST 2 , is probably a higher order sequence than the TST 1. This may be due to waning tectonism and a decrease in the sediment supply from the source. During these tectonically quiescent periods, eustatic controls are greater than tectonic controls.

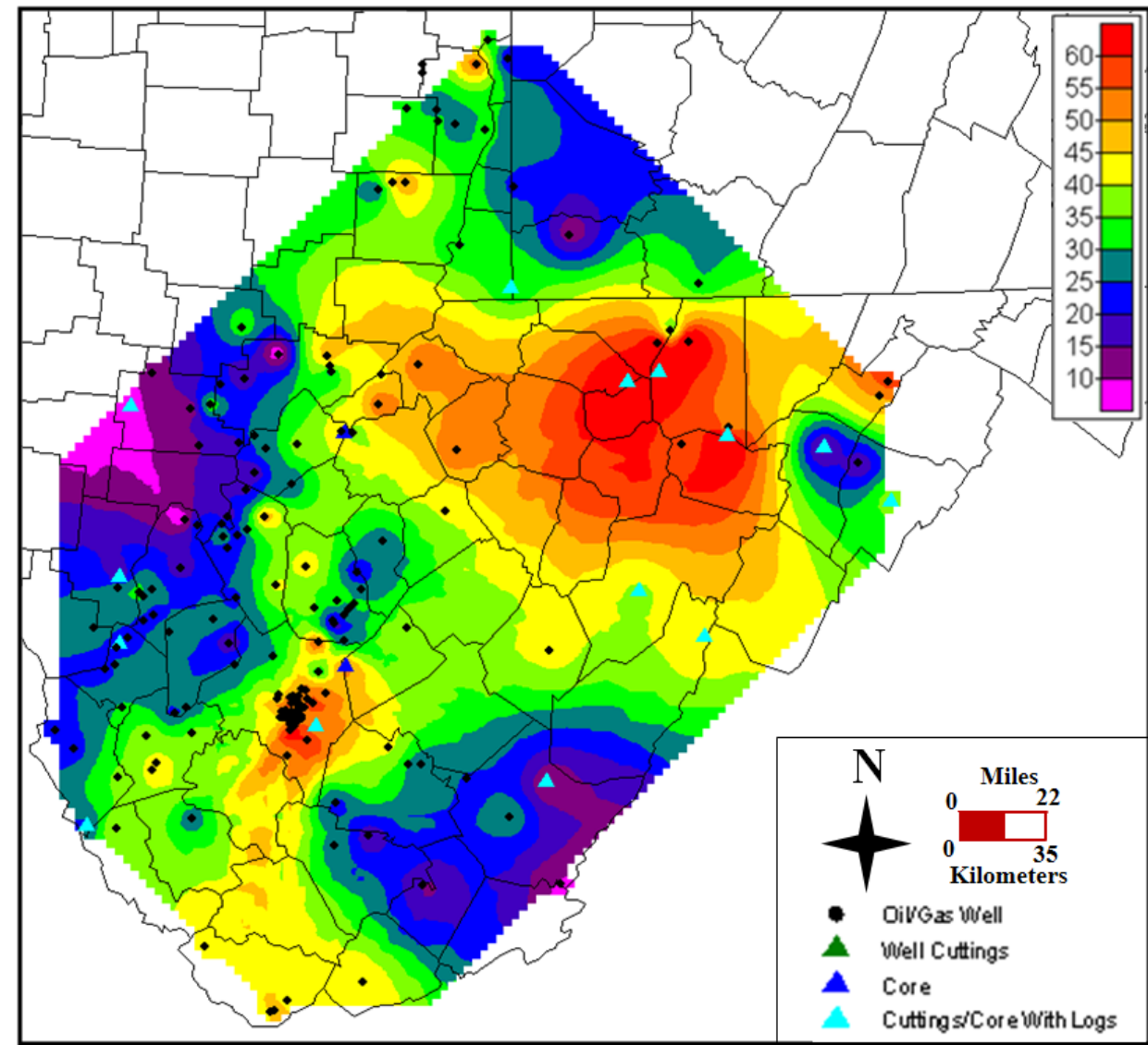

Figure 46: Isopach map of the TST 2. Similar to TST 1 the thickest deposits of TST 2 occur in the west, however, it there is a landward shift to the east where the thickest deposits occur in a northeast trending direction in the center of the state. This shift is interpreted to be a result of a higher order sequence. 


\subsection{Discussion on systems tracts and reservoir properties}

Stratigraphic models are commonly constructed in order to better predict depositional facies and related reservoir quality. The reservoir quality of the strata confined to the RST of the Tuscarora Sandstone is of interest. The David Ward well (API\# 4703902751) in Kanawha County contains sufficient data (core analysis, full log suite) that allows a closer look at the reservoir quality as it relates to depositional facies. Within the RST is the coarse- to pebbly grained sandstone interpreted as being deposited in the upper reaches of a fluvial-estuarine facies. This coarse-grained facies also contains the highest porosity values in wireline logs and thin section analysis (Figure 47) (Bruner, 1983). The higher porosity values in this interval may also be enhanced due to diagenetic processes, including: 1) larger pore volumes to be filled with cement, 2) a smaller surface area available for nucleation of quartz overgrowths, and 3) thicker clay coatings that have a tendency to prevent nucleation of secondary quartz cement (Bruner, 1983). Upwards from this coarse-grained deposits are the finer-grained sandstone and shale, interpreted to have been deposited in tidal flats or a shallow marine setting coincides with a decrease in porosity. Permeability also had the highest recorded permeability values obtained from core analysis and are also within the coarse-grained deposits of the RST.

Other studies from the Appalachian basin have related petrophysical properties to similar depositional facies. In the Appalachian basin, the coarse-grained fluvial and fine- to mediumgrained upper shoreface facies of the Lower Silurian sandstones have the highest porosity values (>10\%) (Castle and Byrnes, 2005). Additionally, the coarse-grained fluvial deposits recorded permeability values 50-70 times greater than the finer grained fluvial facies (Castle and Byrnes, 2005). Likewise, in the Lower Pennsylvanian Morrow sandstone in the Anadarko basin, the proximal upper-estuary channel facies recorded the highest porosity and permeability values. 
Depositional facies exhibiting minimum values include the estuary-funnel, estuary-mouth, lower shoreface, transition, offshore, and shelf deposits (Byrnes et al., 2001)

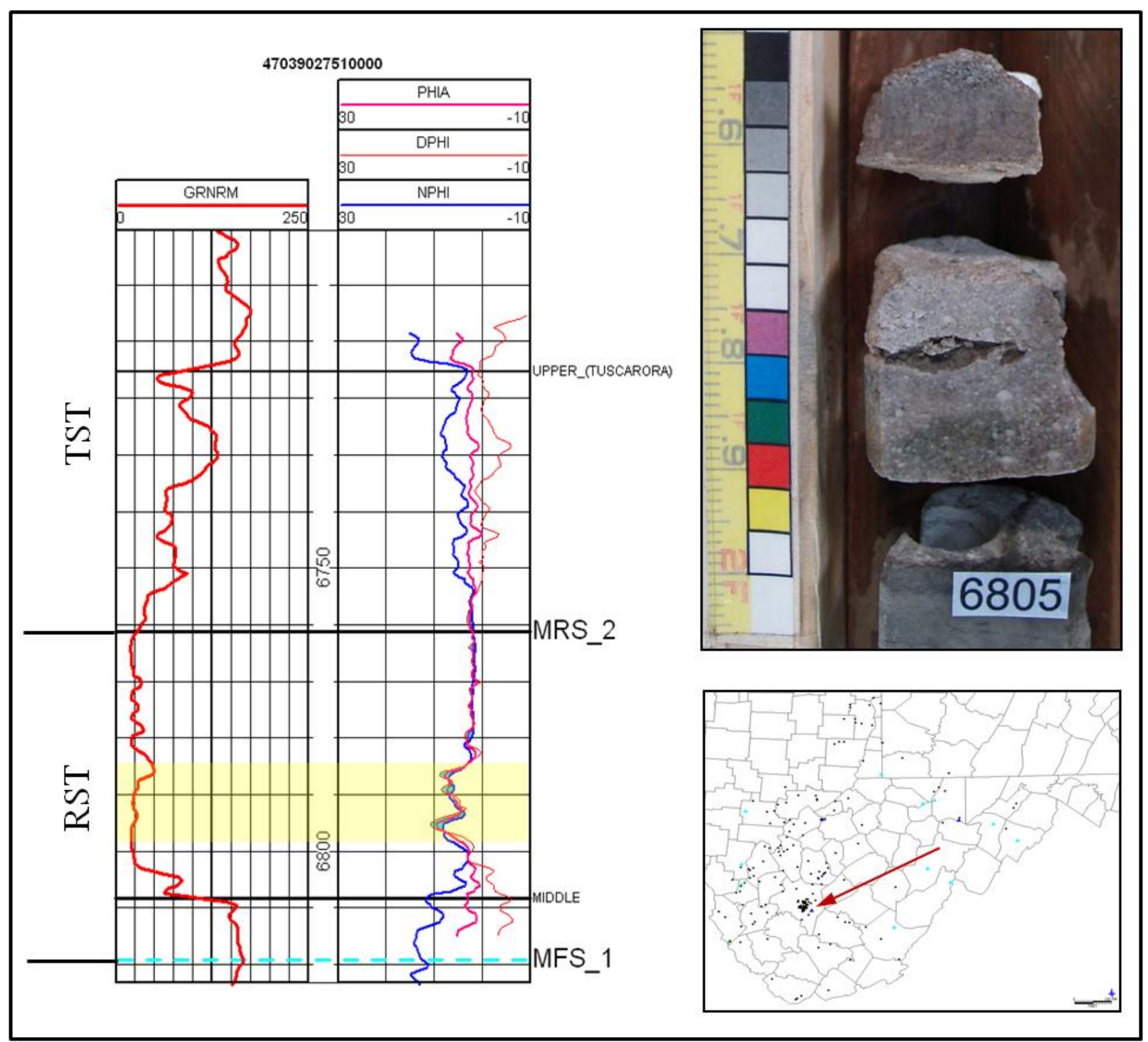

Figure 47: Example of good reservoir properties as related to lithofacies. On the left in track 1 is the gamma-ray log, and in track 2 is the density (red)- neutron (blue)- and average (pink)-porosity logs. The coarse grained interval is highlighted in yellow, note the increase in porosity and gas effect. On the right, core photos of the coarse- to pebbly-grained interval from within the high-porosity zone (core depth is approximately 20 feet shallower than log). 


\section{REGIONAL MAPPING OF RESERVOIR PROPERTIES}

\subsection{Porosity-feet Maps}

Average porosity was calculated for the upper and lower members by averaging the density and neutron porosity logs over the lower and upper intervals. Average porosity was not calculated for the middle member because shale typically has high neutron porosity values due to bound water (Doveton, 1994). Older neutron logs are recorded in counts instead of newer neutron logs, which are recorded as a percentage. These archaic logs can be rescaled using a simple calibration that designates a porosity of $30 \%$ for shales and $1 \%$ porosity for the lowest porosity zones. Porosity then is interpolated between this high and low value on a logarithmic scale (Doveton, 1994). Additionally, when only a density porosity or neutron porosity log was available for a well, the average porosity from the closest available well was cross plotted against the density or neutron log and a regression equation was generated and applied to the well lacking an average porosity log. The lower member has a mean average porosity of $3.3 \%$, ranging from $0-10 \%$.

Due to the shale-rich intervals present in the lower member, calculated log porosity is too high in areas to the southwest. A gamma-ray maximum cut-off of 50 API can be applied to eliminate non-sandstone lithologies and is used to reduce the influence of overvalued porosities where the lower member is shale-rich (Barnes, Bacon, and Kelley, 2009). By multiplying the net-thickness and average porosity (decimal) of the lower member, a porosity-feet map was constructed using 94 wells with a range of values from 0-2.8 porosity-feet (Figure 48). This map is also used as the volume variable in the equation for potential storage volume. There appears to be a northwest-southeast oriented porosity-feet trend, with the highest values in the northeast region. This trend decreases to the west. 


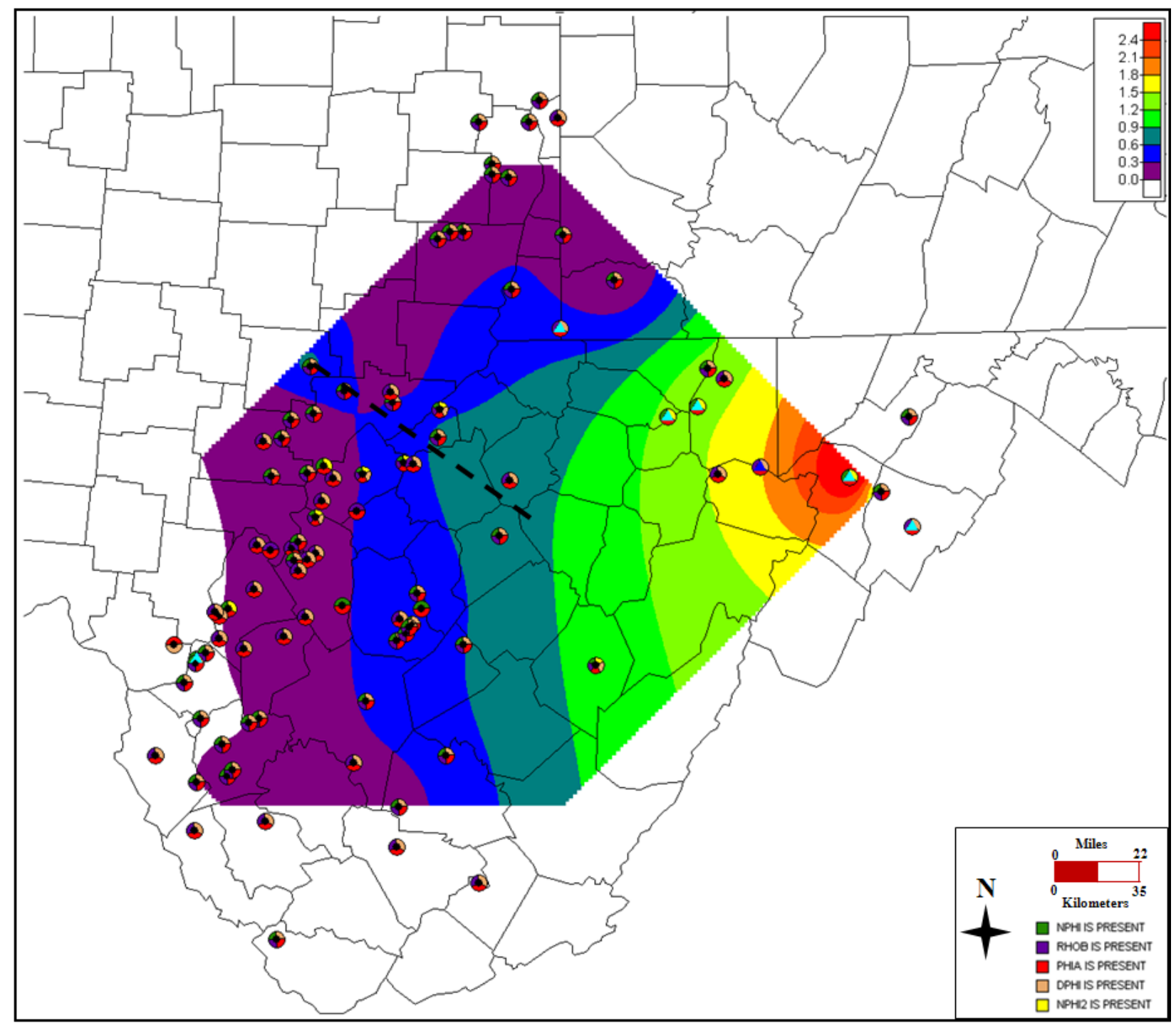

Figure 48: Porosity-feet map of the lower member with a gamma-ray cutoff of 50 API. Note the northwest-southeast trend (black dashed line), that may be related to braided fluvial channels. (NPHI=neutron-porosity, RHOB=bulk density, PHIA=average porosity, DPHI=density porosity, and NPHI2=normalized neutron porosity)

A four well cross-section through this trend shows that it corresponds to relatively thick (20 feet) clean sandstones, interpreted as fluvial incised valley fill with high average porosities densityneutron porosity crossover, indicating the presence of gas (Figure 49). 


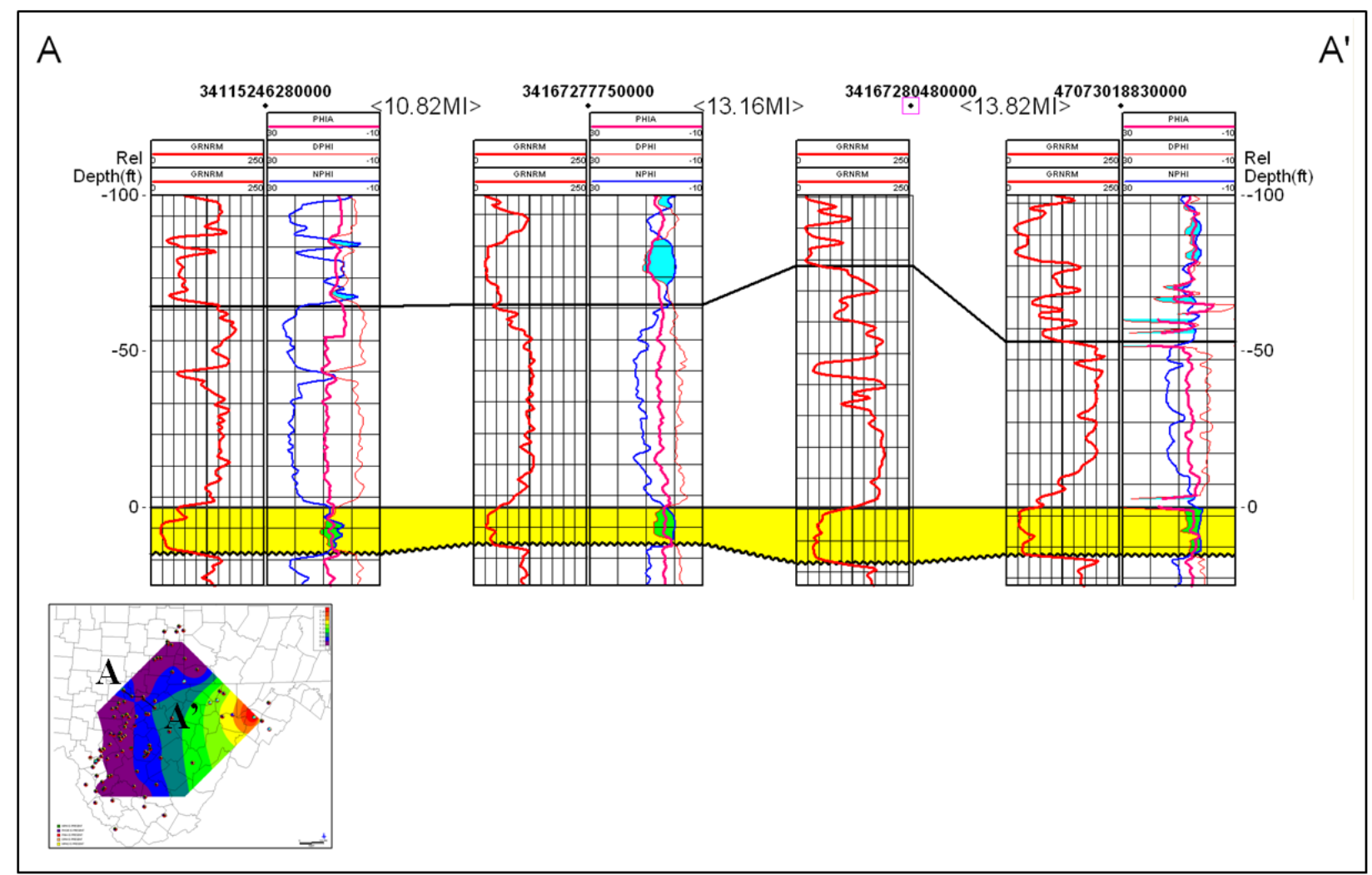

Figure 49: Cross section A-A' through the porosity-feet trend of the basal sand (shaded in yellow) observed in map view, with the lower basal sand used as a datum. The high porosity-feet trend is related to relatively thick ( 20 feet) clean sandstones (turquoise shading indicates crossover)

The average porosity of the upper member ranges from $<1 \%-10.9 \%$ with a mean value of $4.5 \%$. A porosity-feet map was constructed using the same guidelines as for the lower member (Figure 50). The porosity-feet values are much higher than the lower member, due to the thicker strata and higher porosity of the upper member. The highest porosity-feet values occur in the northeast and tend to decrease in value to the west and southwest. 


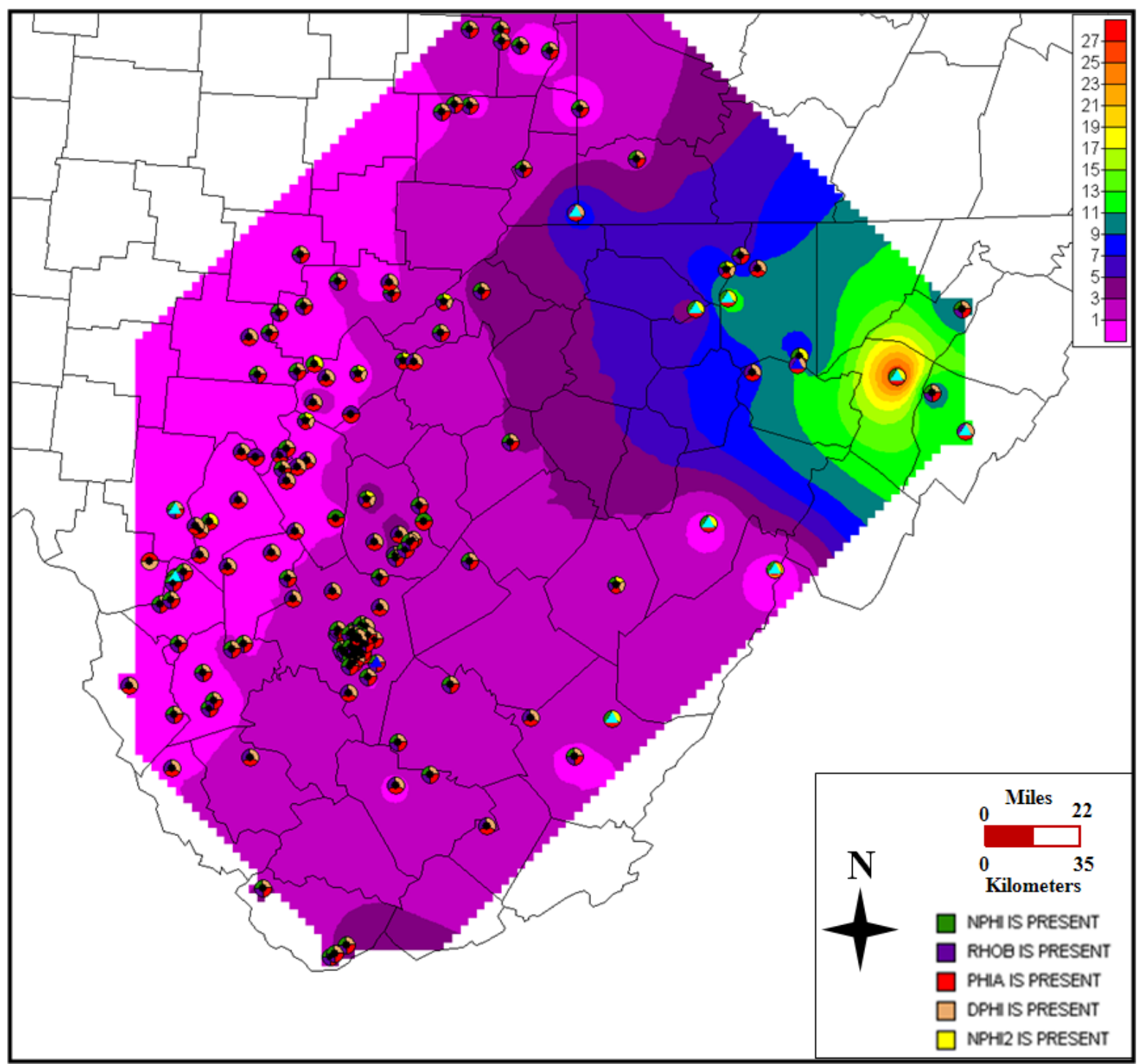

Figure 50: Porosity-feet map of the upper member with a 50 API cutoff. The highest volumes in the northeast correspond to the thick intervals. (NPHI=neutron porosity; $\mathrm{RHOB}=$ bulk density; $\mathrm{PHIA}=$ average porosity; DPHI=density porosity; NPHI2=normalized neutron porosity)

In addition to thick strata of the upper member, high porosity-feet values in the northeast are interpreted to be a result of finite strain associated with deformation mechanisms. In the Allegheny structural front, secondary porosity related to secondary fractures and dissolution of feldspar grains and calcite cement in the Tuscarora Sandstone is observed in core (Wescott, 1982; Mitra, 1988). Further east in the Valley and Ridge province, fractures tend to be filled with quartz and therefore have lower porosity (Mitra, 1988). The position of a bed with respect to major structural features also may enhance porosity. Steepening of the forelimbs of major 
folds results in higher fracture intensities on the steeply dipping west limbs than on the gently dipping east limbs: this is illustrated on the porosity-feet map where a well, drilled on the Wills Mountain anticline in the structural front, has an anomalously high porosity-feet value (Figure

51)

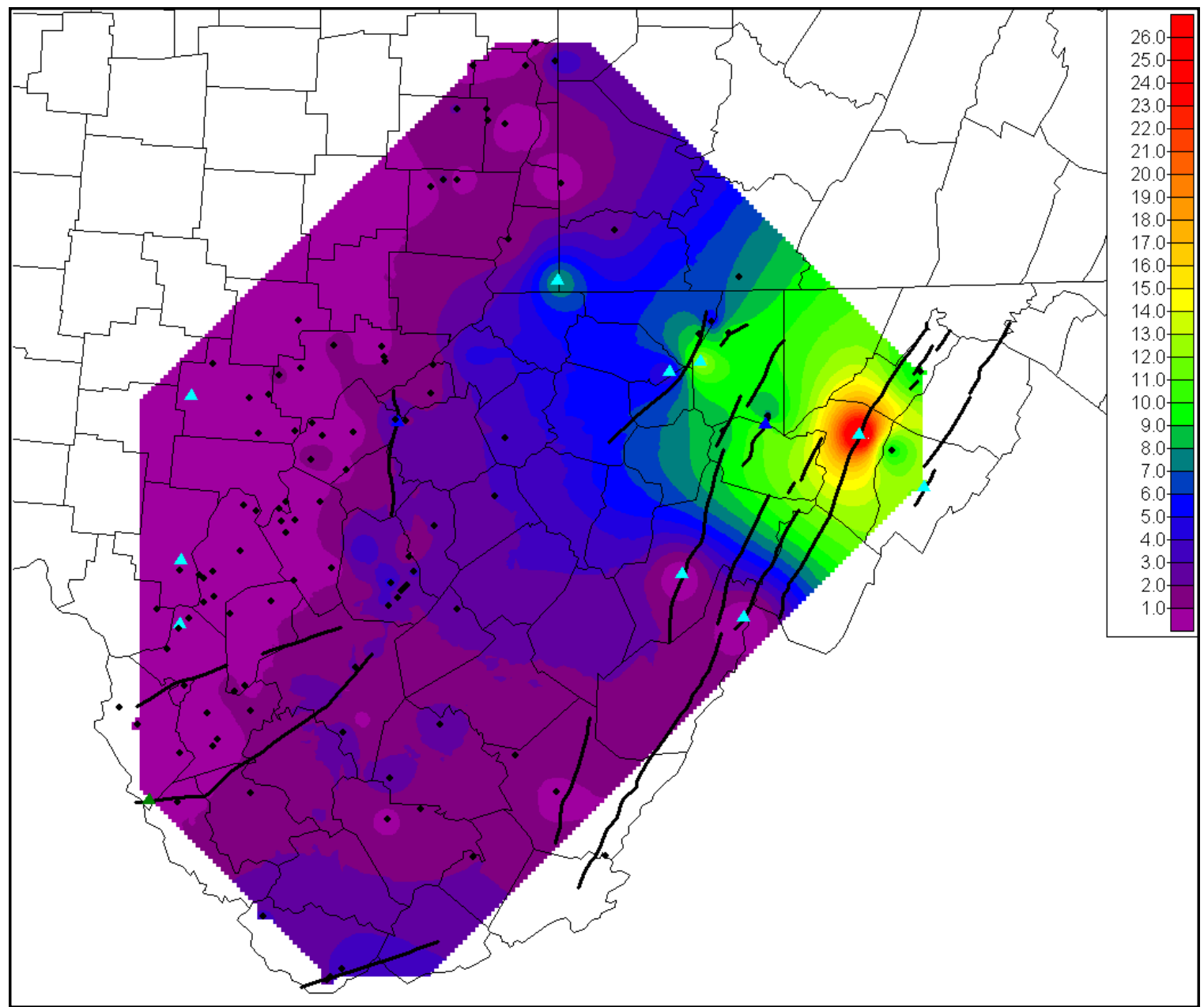

Figure 51: Porosity-feet map with major anticlines (black lines) in West Virginia. Area is pointing to well drilled on the crest of the Wills Mountain anticline in Grant County. The anomalously high pore-feet value in this data point is related to high fracture intensity due to steepening of forelimbs during folding.

\subsection{Formation Depth}

The formation depth is an important reservoir property to consider when injecting carbon dioxide. At standard temperature and pressure, the density of carbon dioxide is $0.11 \mathrm{lbs} / \mathrm{ft}^{3}(1.8$ $\mathrm{kg} / \mathrm{m}^{3)}$, while at the supercritical state, it has a density of $16.23 \mathrm{lbs} / \mathrm{ft}^{3}\left(260 \mathrm{~kg} / \mathrm{m}^{3}\right)(\mathrm{Lemmon}$ et al., 2008). This phase-change and related increase in density allows for a higher storage capacity 
as opposed to the gaseous phase. Under a hydrostatic gradient at a depth of 2,500 feet (762 meters) below the surface, there is a rapid increase in density as the $\mathrm{CO}_{2}$ changes from a liquid to the critical-phase. Therefore, 2,500 feet (762 meters) is considered to be the approximate minimum depth for $\mathrm{CO}_{2}$ storage. Constructing a depth map using the subsea depths of the Tuscarora Sandstone allows for the identification of regions where the depth threshold is or is not satisfied. The depth of the Tuscarora is between 2,100 to $-9,514$ (640 to $-2,900$ meters) feet subsea with an average depth of 5,842 feet (1,780 meters) subsea. In the Valley and Ridge province to the northeast, wells drilled on the Wills Mountain anticline are above sea level and do not satisfy the minimum criteria (Figure 52). To the west the Tuscarora deepens to a maximum of approximately 9,500 feet (2,896 meters) subsea in the basin axis. Further to the west the formation shallows along the basin hinge. 


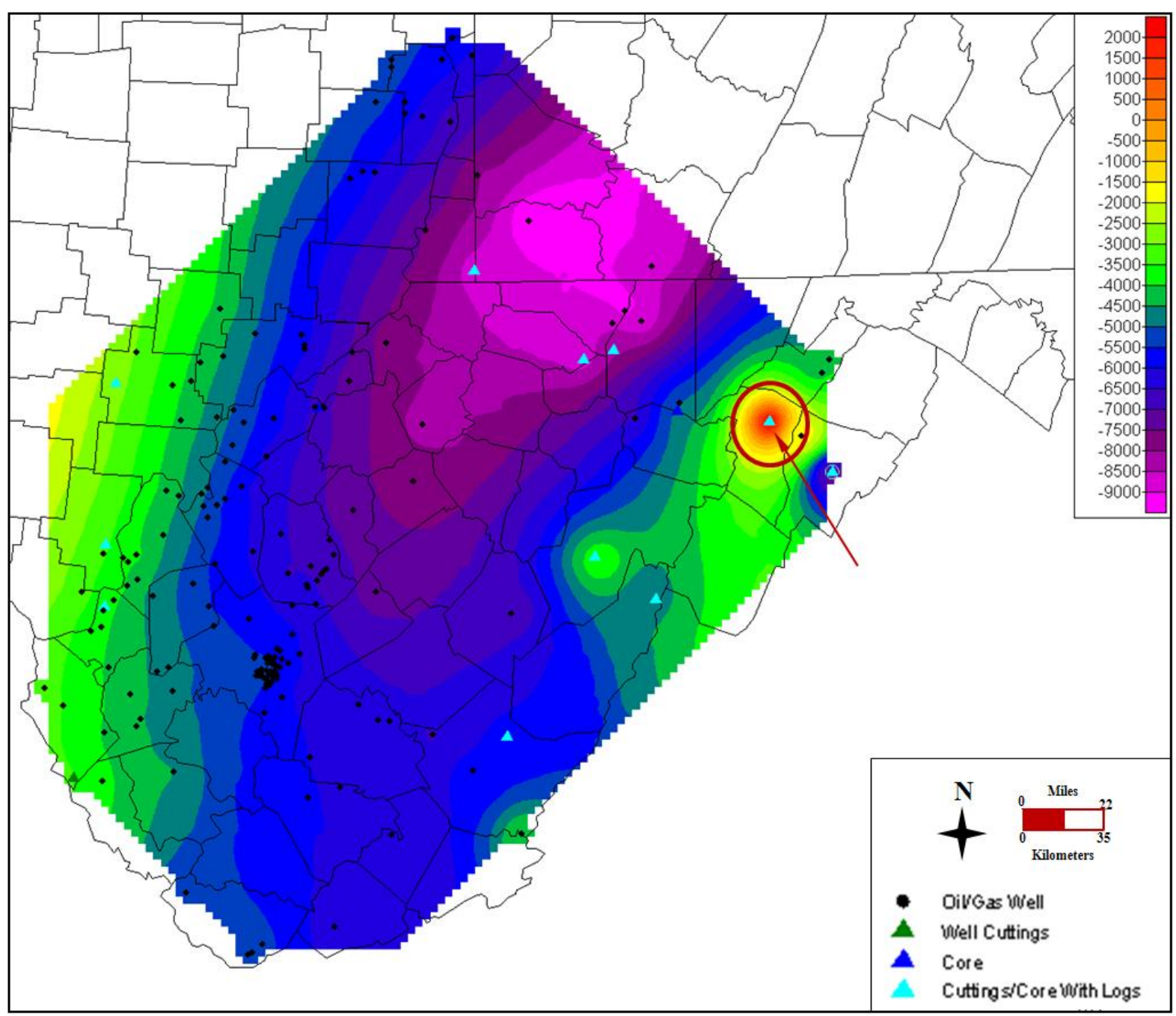

Figure 52: Depth map of the top of the Tuscarora Sandstone relative to sea level. Overall, the trend of formation depth follows the geometry of the central Appalachian basin: from the west to east the formation deepens across the basin hinge and reaches a maximum depth at the basin axis. In the east the formation shallows considerably in the structural front and Valley and Ridge province. Arrow points to a well that is above sea level, drilled on top of the Wills Mountain anticline ( $n=174$ wells). Circle represents the only region in the study area where the minimum depth requirement is not satisfied.

\subsection{Temperature and Pressure Maps}

The critical physical property of $\mathrm{CO}_{2}$ to consider for CCS is density when injected. For CCS analysis, formation temperature and pressure are significant reservoir properties to calculate because at a minimum temperature of $87.8^{\circ} \mathrm{F}\left(31^{\circ} \mathrm{C}\right)$ and a pressure of $1,057 \mathrm{psi}(72.9 \mathrm{amt}), \mathrm{CO}_{2}$ is in a supercritical state, meaning it is dense like a liquid, but with the viscosity of a gas (NETL, 
2012). Injecting $\mathrm{CO}_{2}$ in a supercritical state allows for necessary storage volume to be less than it would be at standard conditions (NETL, 2012)

The formation temperature of the Tuscarora Sandstone at depth is calculated using bottom-hole temperatures (BHT). During logging, recorded BHTs are commonly not at equilibrium with formation temperature and therefore correction is necessary (Carr et al., 2005). This correction can be done by plotting BHT versus depth (Forester et al., 1999). An intercept of $53.6^{\circ} \mathrm{F}$ (average annual surface temperature of West Virginia) is used and a correction factor can be generated by comparing the regression equations. Using 130 wells with BHT, the corrected gradient for $\mathrm{BHT}$ is Tuscarora $\mathrm{BHT}_{\mathrm{T}}=0.011(\mathrm{depth})+53.6$. A strong correlation exists between formation depth and temperature in both the corrected and uncorrected formation temperatures, with an $\mathrm{R}^{2}$ of $100 \%$ for corrected formation temperatures. A geothermal gradient of $1.07^{\circ} \mathrm{F} / 100 \mathrm{ft}$. was calculated using these corrected formation temperatures, which is comparable to the average geothermal gradient of $1.3^{\circ} \mathrm{F} / 100$ feet in the Appalachian basin (Zagorski and Ryder, 2003).

After correcting the BHT, the formation temperature of the Tuscarora was calculated and mapped (Figure 53 and 54). The formation temperature ranges from $86-175^{\circ} \mathrm{F}\left(30-79^{\circ} \mathrm{C}\right)$ with a mean temperature of $128^{\circ} \mathrm{F}\left(53^{\circ} \mathrm{C}\right)$. The formation temperature trend follows the geometry of the Appalachian basin: lower temperatures are observed in shallow regions in the east and west, with a maximum temperature along the basin axis. With the exception of one data point located on the Wills Mountain anticline, the calculated temperature values satisfy the minimum value necessary for $\mathrm{CO}_{2}$ to enter a supercritical state. 


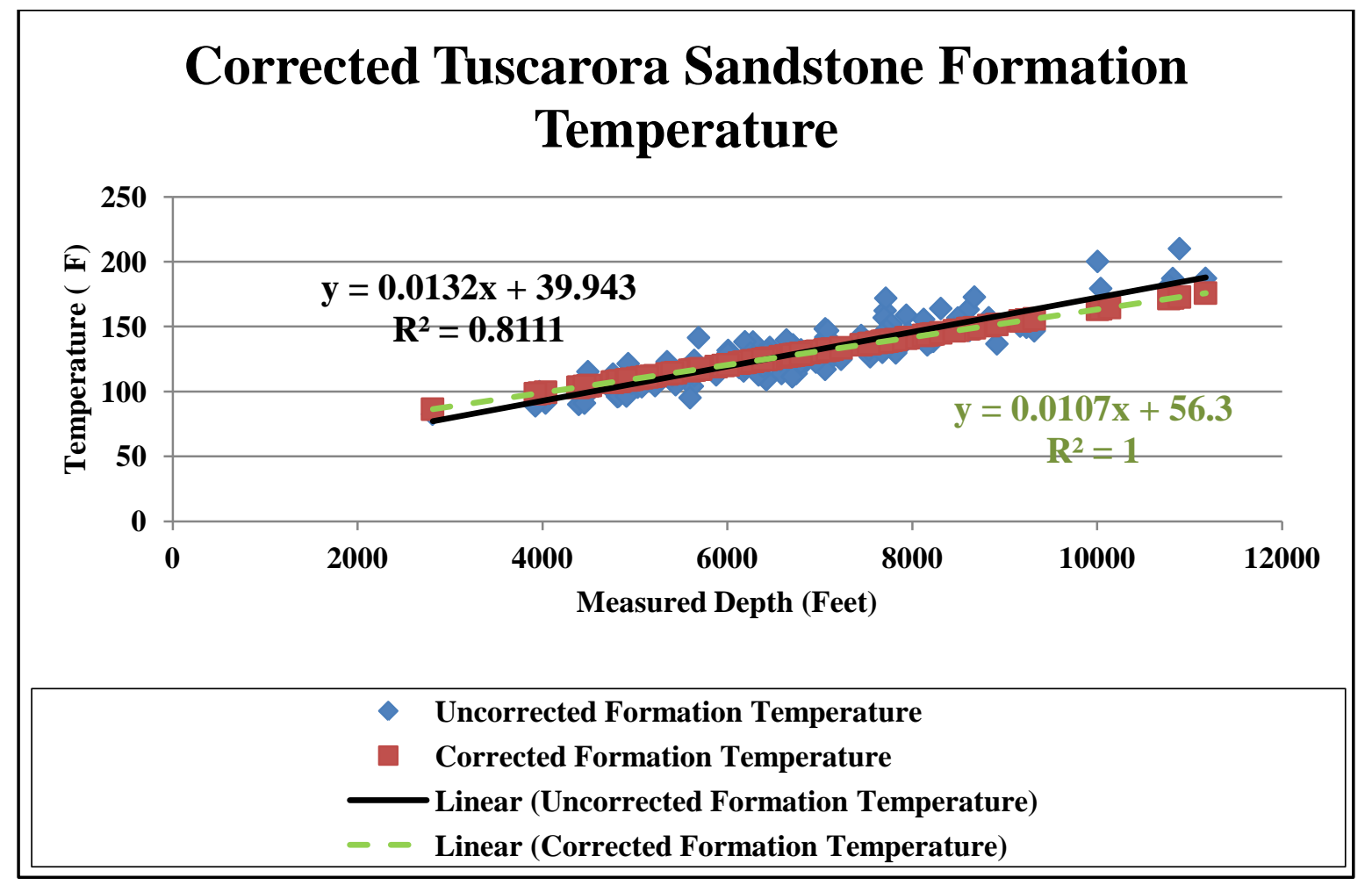

Figure 53: Uncorrected (blue markers) and corrected (red markers) formation temperatures of the Tuscarora Sandstone ( $n=130$ wells) 


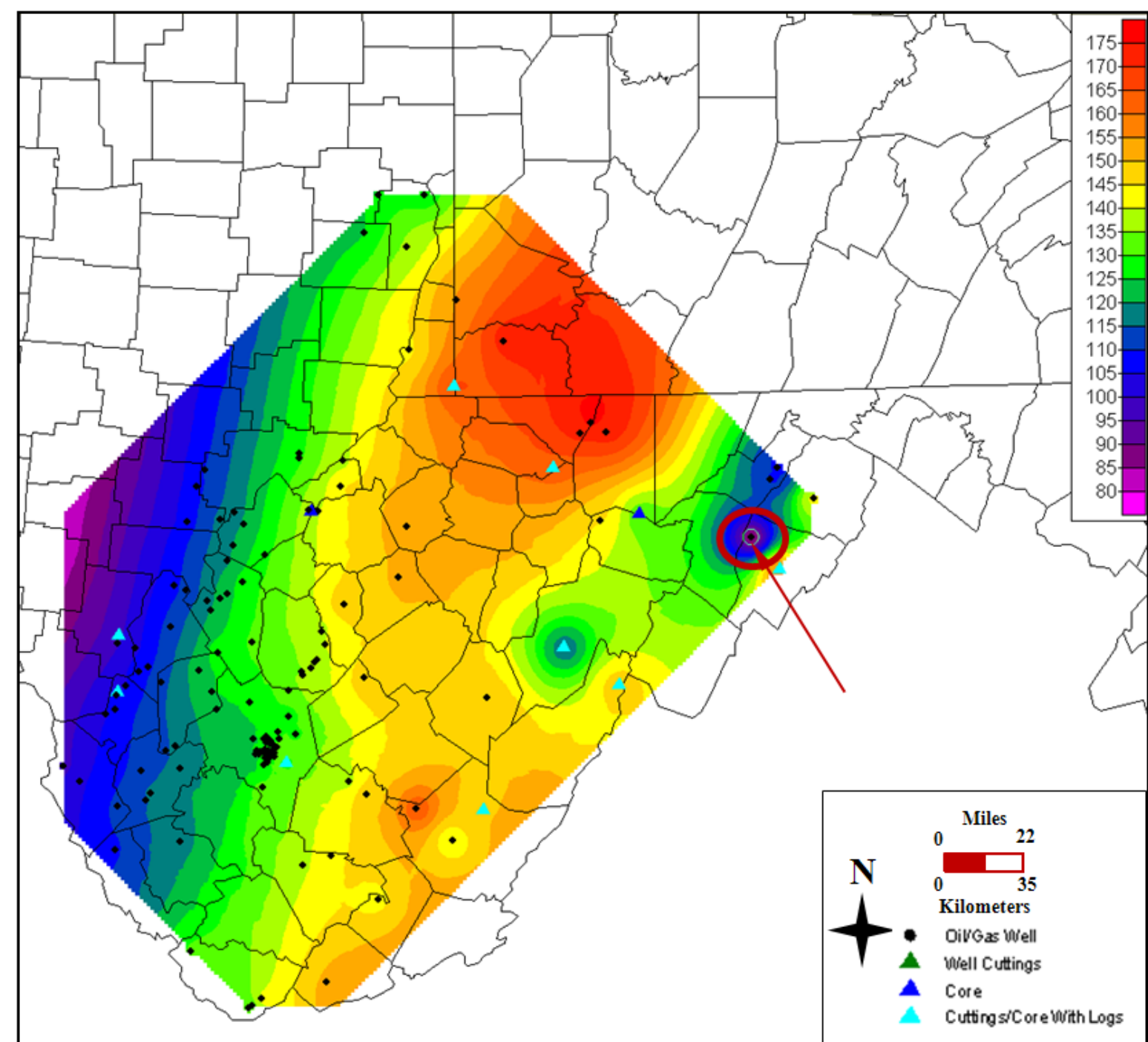

Figure 54: Corrected formation temperatures of the Tuscarora Sandstone. Arrow in the northeast points to data point that does not satisfy minimum temperature requirements, located in the Wills Mountain anticline ( $n=130$ wells). The circle represents the only region in the study area where the minimum temperature criteria is not satisfied.

The formation pressure at which $\mathrm{CO}_{2}$ injected into the formation is another important parameter to consider. The reservoirs of the Lower Silurian regional accumulation are typically under pressured with respect to a normal hydrostatic gradient (0.433 psi/ft) (Zagorski and Ryder, 2003). In the Tuscarora Sandstone, the fluid pressures are more compartmentalized than the Clinton/Medina equivalent, and are considered normal (Indian Creek field) to under pressured (Leadmine field). Using a normal hydrostatic gradient, the formation pressure is calculated by multiplying the formation depth by $0.433 \mathrm{psi} / \mathrm{ft}$ and a pressure map can be constructed; with the 
exception of one data point on the Wills Mountain anticline, the minimum pressure required for $\mathrm{CO}_{2}$ is satisfied (Figure 55).

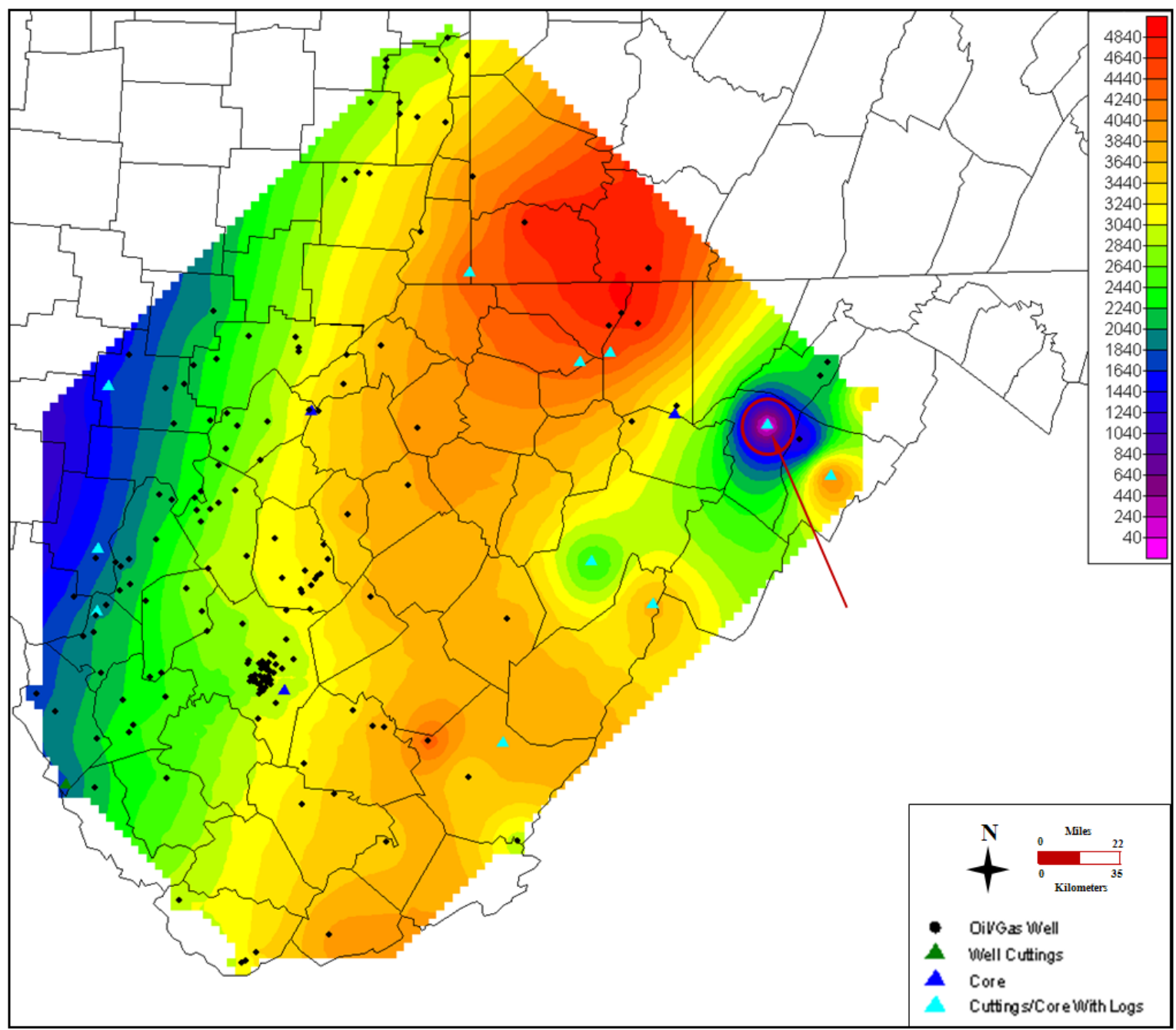

Figure 55: Calculated pressure at formation depth based on a normal hydrostatic gradient of 0.433 psi/ft. The red arrow in the northeast points to data point that does not satisfy the minimum pressure criteria for $\mathrm{CO}_{2}$ storage. Circle represents the only region in the study area where the pressure does not satisfy the minimum criteria. 


\section{$\mathrm{CO}_{2}$ STORAGE CAPACITY IN THE TUSCAORA SANDSTONE IN WEST VIRGINIA}

\subsection{Methodology and calculations}

In order to calculate volumetric storage a general equation provided by the MRCSP for will be used:

\section{$\mathbf{G}_{\mathrm{CO} 2}=A_{t} h_{g} f_{\text {tot }} \rho E$}

where:

$\mathrm{G}_{\mathrm{CO}_{2}}=\mathrm{CO}_{2}$ sequestration capacity (metric tons)

$A_{t}=$ Total area

$h_{g}=$ Gross formation thickness

$f_{\text {tot }}=$ Total porosity

$\rho=\mathrm{CO}_{2}$ density

$E=$ Storage efficiency factor

The porosity-feet grids of the lower and upper member are used as the volume constant $\left(A_{t} h_{g} f_{\text {tot }}\right)$. The porosity-feet maps were clipped along the West Virginia state border as well as along the trend of the Allegheny structural front, due to data points not meeting the minimum depth $(2,500$ feet $)$ or temperature $\left(87.8^{\circ} \mathrm{F}\right)$ requirements for $\mathrm{CO}_{2}$ storage. In order to calculate an average density value, the National Institute of Standards and Technology calculator was used (NIST, 2011). The minimum temperature for $\mathrm{CO}_{2}$ to enter a supercritical phase was entered as the temperature constant and a pressure range of $1,057 \mathrm{psi}$ (minimum pressure need for $\mathrm{CO}_{2}$ to occur in a super-critical state) and a maximum of 4,838 psi (maximum calculated formation pressure in this study) was used. A range of density values was calculated for these parameters and the average density is $53.9 \mathrm{lbs} / \mathrm{ft}^{3}$. The storage efficiency factor is a coefficient that is applied to the calculated maximum storage. The three coefficients for the $\mathrm{P}_{10}, \mathrm{P}_{50}$, and $\mathrm{P}_{90}$ confidence intervals are $0.51 \%, 2.0 \%$, and $5.5 \%$, respectively (NETL, 2012).

The theoretical pore volume of the lower member in the study area is $214,527,166,943 \mathrm{ft}^{3}$ $\left(6.07 \times 10^{9} \mathrm{~m}^{3} ; 4.92 \times 10^{6}\right.$ acre-feet). By multiplying the average $\mathrm{CO}_{2}$ density of $53.9 \mathrm{lbs} / \mathrm{ft}^{3}$ times 
the above theoretical pore volume and converting to metric tons $(2,200 \mathrm{lbs}=$ one metric ton $)$ the unrisked storage potential of the lower member is:

\section{$\mathbf{G}_{\mathbf{C O 2 L o w e r ~ M e m b e r}}=5.26 \times 10^{9}$ metric tons}

Applying the $\mathrm{P}_{10}, \mathrm{P}_{50}$, and $\mathrm{P}_{90}$ storage efficiency coefficients gives values of $5.26 \times 10^{7}, 1.05 \times 10^{8}$, and $2.89 \times 10^{8}$ metric tons, respectively. Multiplying the pore volume grid by the average density of $\mathrm{CO}_{2}$ in a supercritical state allows for identification of regions with high storage potential (Figure 56). The volume map follows a similar trend to the porosity-feet map, with the highest values in the northeast and a decreasing trend to the west-southwest.

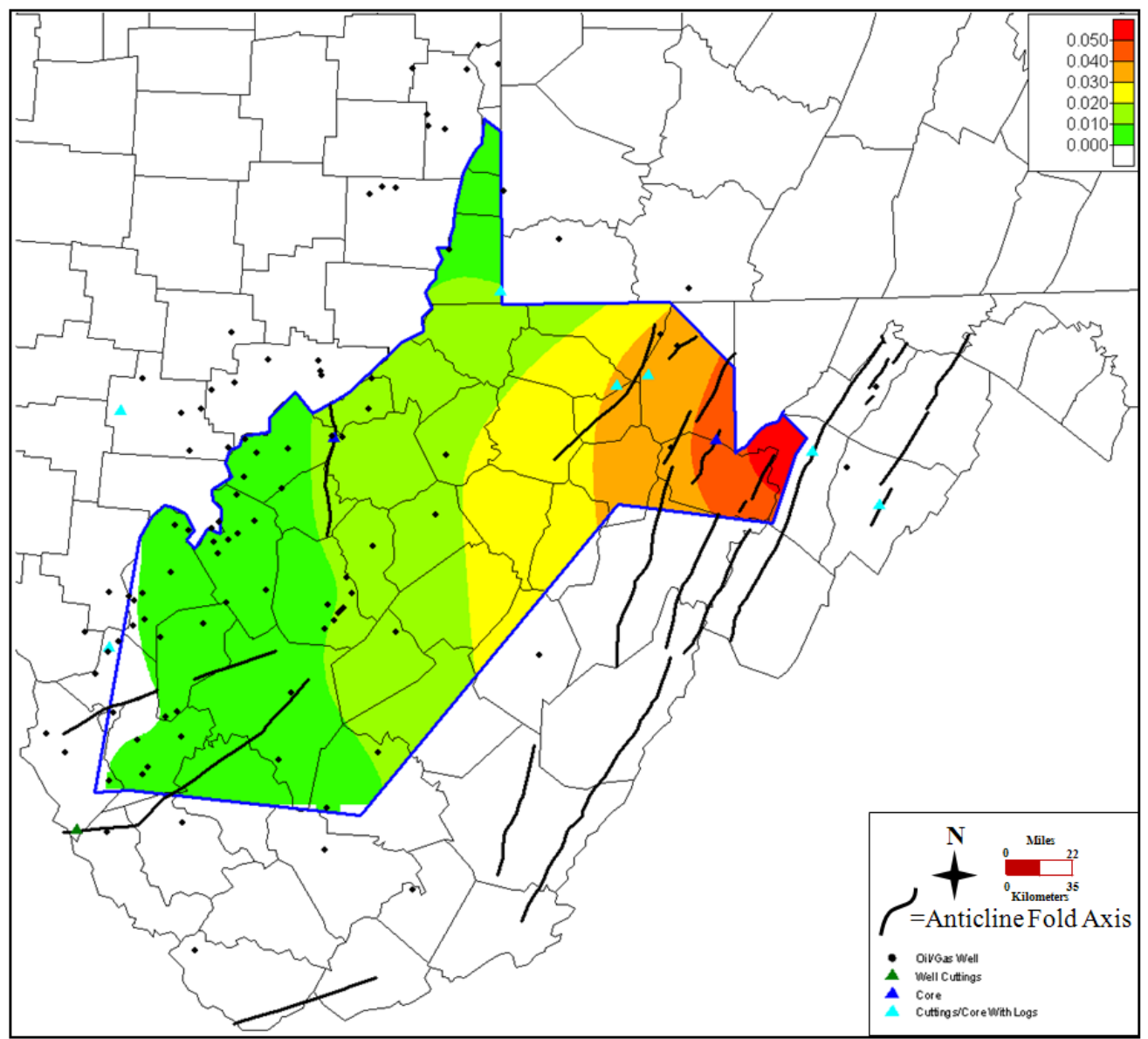

Figure 56: $\mathrm{CO}_{2}$ storage potential in metric tons of the lower member in West Virginia. 
The theoretical pore volume of the upper member is $1,716,743,737,139 \mathrm{ft}^{3}\left(4.86 \times 10^{10} \mathrm{~m}^{3}\right.$; $3.94 \times 10^{7}$ acre-feet).

$$
\mathbf{G}_{\mathbf{C O 2 U p p e r ~ M e m b e r}}=4.21 \times 10^{10} \text { metric tons }
$$

Applying the storage efficiency factors of $\mathrm{P}_{10}, \mathrm{P}_{50}$, and $\mathrm{P}_{90}$ gives values of $2.15 \times 10^{8}, 8.41 \times 10^{8}$, and $2.81 \times 10^{9}$ metric tons, respectively. Similar to the lower member, the upper member has the highest storage potential in the northeast, which decreases to the west-southwest (Figure 54). For comparison, $7.70 \times 10^{7}$ metric tons per year of $\mathrm{CO}_{2}$ are emitted from twenty seven stationary sources in West Virginia (NETL, 2012). Similar to the porosity-feet map of the upper member, the highest storage volumes occur in the northeast, with a decreasing trend to the west-southwest (Figure 57).

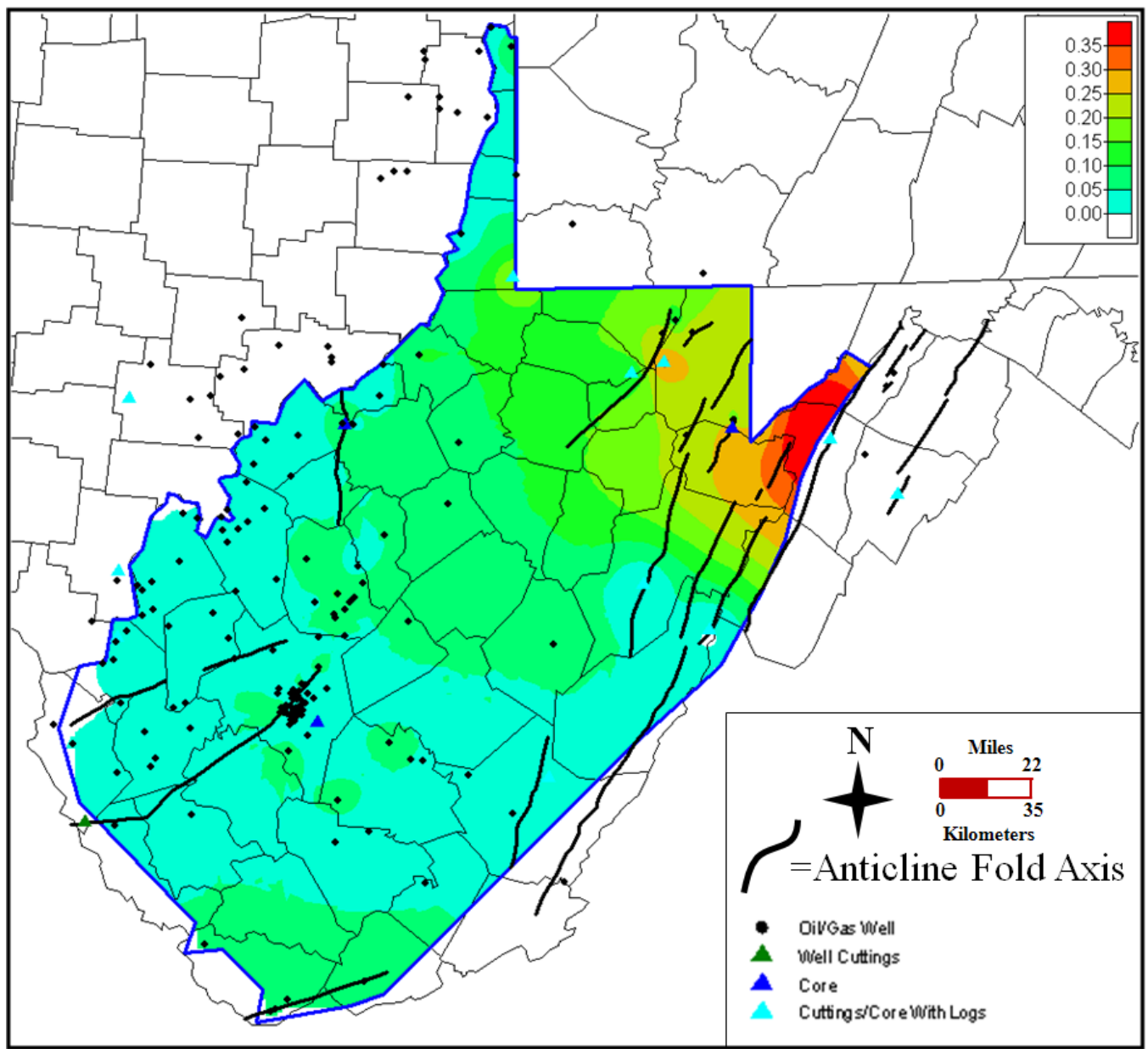

Figure 57: $\mathrm{CO}_{2}$ storage potential in metric tons of the upper member in West Virginia. 


\subsection{Discussion}

The calculated volumes for the lower and upper members are large, and there are several reservoir characteristics of the Tuscarora Sandstone that allow for large calculated volumes. The thick intervals, especially to the northeast and large geographic extent of the upper member allow for high storage potential. In addition, with the exception with one data point in the Allegheny structural front, the Tuscarora Sandstone satisfies the minimum temperature, pressure, and depth criteria needed for $\mathrm{CO}_{2}$. The biggest concern when considering this formation for geologic storage is the low porosity and permeability values. Because of these low values across the study area, it is suggested that a smaller scale analysis of the Tuscarora Sandstone be conducted, perhaps in one of the three key fields in West Virginia.

The Leadmine field is located in the high amplitudes fold region in Preston and Tucker counties. Located on the Deer Park anticlinorium in the structurally complex Allegheny structural front, it contains blind thrusts and anticlinal slices which may serve as traps (Avary, 1996). Thick completion thicknesses and fracturing are the critical reservoir property in this field, although, porosity and permeability values are low: vertical permeability ranges from 012.2 md and horizontal permeability ranges from 0-10.7 md (Avary, 1996). Large initial natural open flows reported in the Leadmine field are probably related to fracture intensity associated with deformation. In spite of high initial open flows, several wells were reported as dry and the only two wells reported as producing have produced about $2.6 \mathrm{bcfg}$ (Avary, 1996). Also located in the high amplitudes fold province is the Cucumber Creek field in McDowell County located on the Dry Fork anticline. Similar to the Leadmine field, this field is structurally complex and is similar in thickness. No production has been reported to the West Virginia Geological Survey for this field, however over eight weeks of flow testing using different tube pressures, 65,903 
million cubic feet of gas (mcfg) and 1,058.6 barrels of water were produced (Avary, 1996). The complex structural nature of this field should be considered a caveat when analyzing potential $\mathrm{CO}_{2}$ storage sites.

The Indian Creek field in Kanawha County is located to the west in the much less structurally complex Appalachian plateau. With thirty three producing wells, it has had the most commercial success of any Tuscarora fields in West Virginia, although some of this success is attributed to high volumes $\mathrm{CO}_{2}$ produced. Over an eleven year period $20 \mathrm{bcfg}$ was produced in the Indian Creek field (Avary, 1996). As discussed in previous sections, some primary porosity may have been preserved as a result of large pore spaces and the presence of clays inhibiting quartz cementation. Additional porosity may be a result of the structural setting of the field: located on the northeast plunging nose of the Warfield anticline, relative upward movement of the Rome trough created the Warfield anticline during the Middle Devonian (Gao, 1994). This movement may have contributed to the fracture porosity in the Tuscarora Sandstone, although most has been filled with secondary quartz (Bruner, 1983). Wells located downdip on the southeast side of this asymmetric anticline are water wet and nonproductive. The Tuscarora Sandstone is also nonproductive downdip to the northwest, off the northeast plunging nose of this structure, possibly due to a pinchout of porosity (Avary, 1996). Due to high volumes of gas produced and density of available data in the area, it is recommended that a more detailed and smaller scale study be completed in the Indian Creek field for $\mathrm{CO}_{2}$ storage. 


\section{CONCLUSIONS AND RECCOMENDATIONS}

Depending on the geographic location, the Lower Silurian Tuscarora Sandstone can be divided into three informal members: a lower, middle, and an upper member. The lower member unconformably overlies the Juniata Formation; it is the stratigraphic equivalent of the Whirlpool Sandstone/Brassfield Limestone of southeast and central Ohio. The lower member was deposited during a rise in sea-level and is present from the southwest to the northeast. In the southwest the lithology can be summarized as a fine-grained carbonate-rich interval with clay beds, sometimes underlain by basal sandstone, which is more prominent in well logs to the north. In the northeast, a medium- to coarse-grained burrowed and trough cross-bedded sandstone is observed in core. The depositional facies of this member varies, but is interpreted to be a deposited in a tidal-influenced environment in the northeast, an offshore environment with limited clastic input to the southwest. To the northwest the more clastic rich interval was deposited in an offshore setting. The basal sandstone that is present was likely deposited in a shallow incised valley, oriented to the west to northwest. A sequence boundary, or maximum regressive surface (MRS), is placed at a thin shale bed that occurs above the unconformity, marking the onset of a fining-upward sequence and marine transgression.

The middle member is the equivalent of the lower Cabot Head Shale of Ohio and is limited to the southwest, northwest, and northeast, and usually present wherever the lower member is present. The dark-gray shale of the middle member is a storm-dominated, offshore marine mud in the west. In the northeast, a tidal-influenced interbedded sandstone and shale is interpreted to be deposited in a muddy embayment. A maximum flooding surface (MFS 1) is placed at the highest gamma-ray value, marking the onset of progradation caused by a fall in sea level. 
The upper member is present throughout the entire state of West Virginia; it is thickest in the northeast and thins to the west-southwest. The thick, burrowed, and trough-cross bedded coarse-grained sandstone deposits in the northeast and southeast are interpreted as being deposited in a paralic environment, with occasional increases in fluvial sedimentation. To the west, the upper member thins and the amount of shale increases, indicating a transition into a more marine environment, possibly estuarine in origin. The lower part of the upper member is placed within the regressive systems tract (RST) and the top of a coarsening-upward sequence in the RST is interpreted as the second sequence boundary (MRS 2) and all strata above are placed into the transgressive systems tract (TST 2) of a second sequence.

As a potential interval for geologic storage of $\mathrm{CO}_{2}$, some preliminary conclusions can be drawn from this evaluation. Because the Tuscarora Sandstone is a gas play, some of the necessary components for CCS are already in place: it is a fractured, anticlinal play with a thick, competent seal overlying it (Rose Hill Formation), indicating it has the potential for high volumes for storage capacity and lateral and vertical containment for long term storage. Also, the majority of the Tuscarora Sandstone occurs at depths below the necessary 2,500 feet required for CCS injection, with some exceptions in the Valley and Ridge province. Additionally, minimum temperatures and pressures are also satisfied.

There are two potential injection intervals in the Tuscarora Sandstone: the lower member, with a calculated unrisked storage volume of $5.26 \times 10^{9}$ metric tons. In the lower member, the sand-rich intervals of the incised valley fill have an overlying regional seal (middle member), which gives it the potential to sucessfully store smaller volumes of $\mathrm{CO}_{2}$. The calculated unrisked storage potential of the upper member is $4.21 \times 10^{10}$ metric tons. The unit has the potential to store high volumes of $\mathrm{CO}_{2}$ due to thick intervals and a vast geographic extent 
across the study area. Higher porosity and permeability values are observed in the intervals of the upper member that occur in the coarse-grained fluvial deposits within the RST.

Although the Tuscarora Sandstone is a thick and extensive deposit, caution is heeded, considering the low porosity and permeability values of the upper and lower members. These poor reservoir qualities may cause difficulties when attempting to inject carbon dioxide and further investigation is recommended. It should also be noted, that storage to the east has a high risk due to the complex structural nature in the Allegheny front and the Valley and Ridge province.

Future studies should take several recommendations into consideration, including:

- Completing a smaller scale study, perhaps in one of the three key Tuscarora fields in West Virginia.

- Conducting a fault and fracture analysis to identify high-risk areas, especially in the structurally complex provinces.

- Comparing production data to reservoir properties such as porosity and permeability. 


\section{REFERENCES CITED}

Avary, K.L., 1996, Play Sts; The Lower Silurian Tuscarora Sandstone fractured anticlinal play, in J.B. Roen, and B.J. Walker, eds., The atlas of major Appalachian gas plays: West Virginia Geological and Economic Survey Publication ,v.25, p. 151-155.

Bachu, S., 2001., Screening and ranking of hydrocarbon reservoirs for $\mathrm{CO}_{2}$ torage in the Alberta Basin, Canada: US Department of Energy - National Energy Technology Laboratory, National Conference on Carbon Sequestration, 5, Washington D. C.

Bambach, R.K., 1987, The Ordovician-Silurian unconformity in western Virginia and adjacent West Virginia, in Shumaker, R.C., compiler, Proceeding, Appalachian Basin Industrial Associates Fall Meeting: Morgantown, West Virginia, Appalachian Basin Industrial Associates, West Virginia University, v. 13, p. 2-14.

Barnes, D.A., D.H. Bacon, and S.R. Kelley, 2009, Geological sequestration of carbon dioxide in the Cambrian Mount Simon Sandstone: Regional storage capacity, site characterization, and large-scale injection feasibility, Michigan basin: American Association of Petroleum Geologists/Division of Environmental Geosciences, v. 16, no. 3.

Bayles, R.E., W.H. Henry, C.R. Fettke, L.D. Harris, R.R. Flowers, and O.L. Haught, 1956, Wood County deep well: West Virginia Geological and Economic Survey Report of Investigations No. 14, 61 p.

Beecy, D.A., V.A. Kuuskraa, and C. Schmidt, 2002, A perspective on the potential role of geologic options in a national carbon management strategy: Journal of Energy and Environmental Research, v.2, no.1. p. 47-53. (from U.S. Department of Energy, National Energy Technology Laboratory, First National Conference on Carbon Sequestration, 2001.

Behling, M.C., S. Pool, D.G. Patchen, and J.A. Harper, 2008, Improving the availability and delivery of critical information for tight gas resource development in the Appalachian basin,: United States Department of Energy, DOE Award No. DE-FC26-05NT42661.

Berry, W.B.N. and A.J. Boucot, 1970, Correlation of the North American Silurian Rocks: Geological Society of America Special Paper 102, 289 p.

Blakey, R., 2011, Paleogeography and geologic evolution of North America, <http:// http://www2.nau.edu/rcb7/nam.html> Accessed November 5, 2012.

Brett, C.E., W.M Goodman, and S.T. LoDuca, 1990, Sequence, cycles and basin dynamics in the Silurian of the Appalachian foreland basin: Sedimentary Geology, v.69, no.3/4, p.191-244.

Brett, C.E., D.H. Tepper, W.M. Goodman, S.T. LoDuca, and B.Y. Eckert, 1995, Revised stratigraphy and correlations of the Niagaran Provincial Series (Medina, Clinton, and 
Lockport Groups) in the type area of western New York: U.S. Geological Survey Bulletin 208, 66 p.

Brett, C.E., B.B. Baarli, T. Chowns, E. Cotter, S.Driese, W. Goodman, and M.E. Johnson, 1998, Early Silurian condensed intervals, ironstones, and sequence stratigraphy in the Appalachian foreland basin, in E. Landing and M.E. Johnson, eds., Silurian cycles: Linkages of dynamic stratigraphy with atmospheric, oceanic, and tectonic changes: New York State Museum Bulletin 491, p. 89-143.

Brenchley, P.J., 1989, The Late Ordovician extinction, in, S.K. Donovan, ed., Mass Extinctions - Processes and Evidence: New York, Columbia University Press, p. 104132.

Byrnes, A.P, L.A. Buatois, M.G. Mángano, and T.R. Carr, 2001, Integration of lithofacies and petrophysics in marine and estuarine Morrow Sandstone, southwest Kansas: a midcontinent rock catalog example, in K.S. Johnson, ed., Pennsylvanian and Permian geology and petroleum in the southern Midcontinent, 1988 symposium: Oklahoma Geological Survey Circular 103, p. 59-64

Blatt, H., G. Middleton, and R. Murray, 1980, Origin of Sedimentary Rocks: Englewood Cliffs, New Jersey, Prentice-Hall, 782 p.

Bruner, K.R., 1983, Petrology and diagenesis of the Lower Silurian Tuscarora Sandstone, Kanawha County, West Virginia: Master's thesis, West Virginia University, Morgantown, West Virginia, 148 p.

Carr, T.R., D.F. Merriam, and J.D. Bartley, 2005, Use of relational databases to evaluate regional petroleum accumulation, groundwater flow, and $\mathrm{CO}_{2}$ sequestration in Kansas: American Association of Petroleum Geologists Bulletin, v. 89, p. 1607-1627.

Castle, J.W., 1998, Regional sedimentology and stratal surfaces of a Lower Silurian clastic wedge in the Appalachian foreland basin: Journal of Sedimentary Research, v.68, no.6, p. 1201-1211.

Castle, J.W., 2001a, Appalachian basin stratigraphic response to convergent-margin structural evolution: Basin Research, v.13, p. 397-418.

Castle, J.W., 2001b, Foreland-basin sequence response to collisional tectonism: Geological Society of America Bulletin, v.113, no.7, p. 801-812.

Castle, J.W. and A.P. Byrnes, 2005, Petrophysics of Lower Silurian sandstones and integration with the tectonic-stratigraphic framework, Appalachian basin, United States: American Association of Petroleum Geologist Bulletin, v.89, no.1, p. 41-60.

Catuneanu, O., 2006, Principles of sequence stratigraphy $1^{\text {st }}$ ed.: Amsterdam, Elsevier, 375 p. 
Cheel, R.J., and G.V. Middleton, 1993, Directional scours on a transgressive surface: examples from the Silurian Whirlpool Sandstone of Southern Ontario, Canada: Journal of Sedimentary Petrology, v. 63, no. 3, p. 392-397.

Cotter, E., 1982, Tuscarora Formation of Pennsylvania: Guidebook: Society of Economic Paleontologists and Mineralogists Eastern Section 1982 Field Trip, 105 p.

Cotter, E., 1983, Shelf, paralic, and fluvial environments and eustatic sea-level fluctuations in the origin of the Tuscarora Formation (Lower Silurian) of Central Pennsylvania: Journal of Sedimentary Petrology, v.53, p.25-49.

Dalrymple, R.W., B.A. Zaitlin, and R. Boyd, 1992, Estuarine facies models: Conceptual basis and stratigraphic implications: Journal of Sedimentary Petrology, v. 62, p. 1130-1146.

Dennison, J.M., 1970, Silurian stratigraphy and sedimentary tectonics of southern West Virginia and adjacent Virginia, in Silurian stratigraphy, central Appalachian basin: Appalachian Geological Society Field Guide, p. 2-33.

Dennison, J.M. and J.W. Head, 1975, Sea level variation interpreted from Appalachian basin Silurian and Devonian: American Journal of Science, v. 275, p. 1089-1120.

Dennison, J.M. and W.H. Wheeler, 1975, Stratigraphy of Precambrian through Cretaceous strata of probably fluvial origin in southeastern United States and their potential as uranium host rocks: Southeastern Geology, Special Publication No.5, 210 p.

Dennison, J.M., R.K. Bambach, S.L. Dorobek, J.K. Filer, and J.A. Shell, 1992, Silurian and Devonian unconformities in southwestern Virginia, in J.M. Dennison, and K.G. Stewart eds., Geologic Field Guides to North Carolina and Vicinity: Chapel Hill, North Carolina, University of North Carolina at Chapel Hill, Department of Geology, Geologic Guidebook No. 1, p. 79-105.

Diecchio, R.J, 1985, Post-Martinsburg Ordovician stratigraphy of Virginia and West Virginia: Virginia Division of Mineral Resources Publication 57, 77 p.

Dorsch, J., R.K. Bambach, and S.G. Driese, 1994, Basin-rebound origin for the "Tuscarora unconformity" in southwestern Virginia and its bearing on the nature of the Taconic orogeny: American Journal of Science, v.294, p. 237-255.

Dorsch, J. and S.G. Driese, 1995, The Taconic foredeep as sediment sink and sediment exporter: implications for the blanket origin of the white quartzarenite blanket (Upper Ordovician-Lower Silurian) of the central and southern Appalachians: American Journal of Science, v. 295, p. 201-243.

Doveton, J.H, 1994, Geological log interpretation: SEPM Short Course Notes No. 29: Society for Sedimentary Geology. 
Driese, S.G., M.W. Fischer, K.A. Easthouse, G.T. Marks, A.R. Gogola, and A.E. Schoner, 1991, Model for genesis of shoreface and shelf sandstone sequences, southern Appalachians: Paleoenvironmental reconstruction of an Early Silurian shelf system, in D.J.P Swift, G.F. Oertel, R.W. Tillman, and J.A. Thorne, eds., Shelf sand and sandstone bodies, geometry, facies, and sequence stratigraphy: International Association of Sedimentologists Special Publication 14, p. 309-378.

Duke W.L, P.J. Fawcett, and W.C. Brusse, 1991, Prograding shoreline deposits in the Lower Silurian Medina Group, Ontario and New York: Storm- and tide-influenced sedimentation in a shallow epicontinental sea, and the origin of enigmatic shore-normal channels encapsulated by open shallow-marine deposits, in D.J.P Swift, G.F. Oertel, R.W. Tillman, and J.A. Thorne eds., Shelf sand and sandstone bodies, geometry, facies, and sequence stratigraphy: International Association of Sedimentologists Special Publication 14, p. 339-375.

EIA, 2011, Emissions of greenhouse gases in the United States 2009: Energy Information Agency, U.S. Department of Energy, $18^{\text {th }}$ edition, $77 \mathrm{p}$.

Embry, A.F., and E. Johannessen, 1992, T-R sequence stratigraphy, facies analysis and reservoir distribution in the uppermost Triassic-Lower Jurassic succession, western Sverdrup Basin, Arctic Canada, in. T.O Vorren, E. Bergsager, $\varnothing$.A. Dahl-Stamnes, E. Holter, B. Johansen, E. Lie, and T.B. Lund., eds., Arctic geology and petroleum potential: Norwegian Petroleum Society Special Publication 2, p. 121-146.

Embry, A.F., 1995, Sequence boundaries and sequence hierarchies: problems and proposals, in R.J. Steel, V.L. Felt, E.P. Johannessen, C. Mathieu, eds., Sequence stratigraphy on the northwest European margin, v.5, Norwegian Petroleum Society, p. 1-11.

Embry, A.F., 2002, Transgresssive-regressive (T-R) sequence stratigraphy: Gulf Coast SEPM Conference Proceedings, p. 151-172.

Ettensohn, F.R., 1994, Tectonic control on the formation and cyclicity of major Appalachian unconformities and associated stratigraphic sequences, in Dennison, J.M., and F.R.Ettensohn, eds., Mississippian Oolites and Modern Analogues: American Associaton of Petroleum Geologists Studies on Geology 35, 13-30.

Ettensohn, F.R. \& C.E. Brett, 2002: Stratigraphic evidence from the Appalachian basin for continuation of the Taconian orogeny into Early Silurian time: Physics and Chemistry of the Earth, v. 27, 279-288.

Faill, R.T., 1997, A geologic history of the north-central Appalachians, Part 2: The Appalachian basin from the Silurian through the Carbonifierous: American Journal of Science, v.297, p. 729-761. 
Folk, R.L., 1960, Petrography and Origin of the Tuscarora, Rose Hill, and Keefer Formations, Lower and Middle Silurian of Eastern West Virginia: Journal of Sedimentary Petrology, v.30, p. 1-68.

Forester, A., D.F. Merriam, and W.L Watney, 1999, Problems and potential of industrial temperature data from a cratonic basement environment, in A. Forester and D.F. Merriam, eds., Geothermics in basin analysis: New York, Plenum Press, p. 35-59.

Gautier, D.L. and K.L., Varnes, 1993, Plays for assessment in region VIII, eastern as of October, 4, 1993, 1995 national assessment of oil and gas, U.S. geological Survey Open File Report 93-596 H, 23 p.

Gao, D., 1994, Subsurface geometry and growth history of the Warfield structure in southcentral West Virginia, central Appalachian basin: Master's thesis, West Virginia University, Morgantown, 243 p.

Grabau, A.W., 1913, Early Paleozoic delta Deposits of North America: Geological Society of America Bulletin, v. 24, p. 399-528.

Gogola, A.R., 1990, Depositional and diagentic history of the Lower Silurian "basal transgressive sandstone" in the southern Appalachians: M.S. thesis, University of Tennessee, Knoxville, 142 p.

Goodman, W.M. and C.E. Brett, 1994, Tectonic vs. eustatic controls on the stratigraphic architecture of the Silurian northern Appalachian basin: Society of Economic Paleontologists and Mineralogists Special Publication, Concepts in Sedimentology and Paleontology, v.4.

Harper, J.A., D.B. Tatlock, and R.T. Wolfe, 1996, Shallow oil and natural gas, in Shultz, C.H., ed., The geology of Pennsylvania, Part VII, Chapter 38-A: Pennsylvania Bureau of Topographic and Geologic Survey, Fourth Series, Special Paper no. 1.

Hettinger, R.D., 2001, Subsurface correlations and sequence stratigraphic interpretations of Lower Silurian strata in the Appalachian basin of northeast Ohio, southwest New York, and northwest Pennsylvania: U.S. Geological Survey Geologic Investigations Series Map I-2741, 1 sheet, scale about 1:2,000,000, 22-p. text.

IPCC AR4 SYR (2007), Core Writing Team; Pachauri, R.K; and Reisinger, A., eds., Climate Change 2007: Synthesis Report, Contribution of Working Groups I, II and III to the Fourth Assessment Report of the Intergovernmental Panel on Climate Change, IPCC.

Jacobi, R.D., 1981, Peripheral bulge-a mechanism for the Lower-Middle Ordovician unconformity along the Western Margin of the Northern Appalachians: Earth and Planetary Science Letters, v. 56, p. 245-251. 
Johnson, M., 1998, The sedimentology of the Lower Silurian Whirlpool Sandstone in subsurface Lake Erie, Ontario: Master's thesis, Brock University, Ontario, Canada 199 p.

Johnson, M.E., D.L. Kaljo, and J.-Y. Rong, 1991, Silurian eustasy: Special Papers in Paleontology, v. 44, 145-163.

Johnson, M.E. and W.S. McKerrow, 1991, Sea level and faunal changes during the latest Llandovery and earliest Ludlow (Silurian): Historical Biology, v.5, p.153-69.

Knight, W.V., 1969, Historical and economic geology of Lower Silurian Clinton Sandstone of northeastern Ohio: American Association of Petroleum Geologist Bulletin, v.53, p. $1,421-1,452$.

Kostelnik, J. and K.M. Carter, 2009, Unraveling the stratigraphy of the Oriskany Sandstone: A necessity in assessing its site-specific carbon sequestration potential: Environmental Geosciences, v. 16, p. 187-200.

Laughrey, C.D., 1984, Petrology and reservoir characteristics of the Lower Silurian Medina Group Sandstones, Athens and Geneva Fields, Crawford County, Pennsylvania: Commonwealth of Pennsylvania Department of Environmental Resource Management, Bureau of Topography and Geological Survey Mineral Resources Report 85, 125 p.

Lemmon, E.W., M.O. McLinden, and D.G. Friend, 2008, Thermophysical properties of fluid systems, in NIST Chemistry WebBook, NIST Standard Reference Database Number 69, P.J. Linstrom and W.G. Mallard, eds., National Institute of Standards and Technology, Gaithersburg, MD, 20899, <http://webbook.nist.gov> Accessed February 20, 2013.

Lukasik, D.M., 1988, Lithostratigraphy of Silurian rocks in southern Ohio and adjacent Kentucky and West Virginia: Ph.D. thesis, Cincinnati, University of Cincinnati, 401 p.

Macedo, J. and S. Marshak 1999, The geometry of fold-thrust belt salients: Geological Society of America Bulletin, v. 111, p. 1808-1822.

Martens, J.H.C., 1945, Well-sample records: West Virginia Geological Survey Volume XVII, $889 \mathrm{p}$.

Martini, I.P., 1971, Regional analysis of sedimentology of Medina Formation (Silurian), Ontario, and New York: American Association of Petroleum Geologists Bulletin, v. 55, p. 12491261.

Middleton, G.V., M. Rutka, and C.J. Salas, 1987, Depositional environments in the Whirlpool Sandstone Member of the Medina Group, in Duke, W.L., ed, Sedimentology, stratigraphy, and ichnology of the Lower Silurian Medina Formations in New York and Ontario, Society of Economic Paleontologists and Mineralogists, Eastern Section, 1987 annual field trip guidebook, p.1-15. 
Mitra, S., 1988, Effects of deformation mechanisms on reservoir potential in central Appalachian overthrust belt: American Association of Petroleum Geologists Bulletin, v. 72, no. 5, p. 536-554.

Murphy, T.B., 1984, Diagenesis and porosity reduction of the Tuscarora sandstone, central Pennsylvania: Master's thesis, University of Missouri, Columbia, Missouri, 104 p.

Nelson, R.A., 1985, Geologic analysis of naturally fractured reservoirs: Contributions in Petroleum Geology and Engineering v. 1, Gulf Publishing, Houston, 320 p.

NETL, 2012, Carbon utilization and storage atlas: National Energy Technology Laboratory, U.S. Department of Energy, $4^{\text {th }}$ edition, 130 p.

NIST (National Institute of Standards and Technology), 2011, Thermophysical properties of fluid systems, < http://webbook.nist.gov/chemistry/fluid/> Accessed March 13, 2013.

Oliver, W.A.J.R., W.J.R. Dewitt, J.M. Dennison, D.M. Hoskins, and J.W. Huddle, 1967, Devonian of the Appalachian basin, United States, in D.H. Oswald, ed., International Symposium on the Devonian System: Alberta Society of Petroleum Geologist, v.1, p.1001-1040.

Patchen, D.G., 1968, A summary of Tuscarora Sandstone (Clinton sand) and pre-Silurian test wells in West Virginia: West Virginia Geological and Economic Survey, Circular C-8, 34 p.

Perry, W.J., 1962, Investigation of the Brassfield-Tuscarora (Clinch) correlation problems in Albion Series in western West Virginia and eastern Kentucky: West Virginia. Academy of Science Proceedings, v.34, p.103-113.

Piotrowski, R.G., 1981, Geology and natural gas production of the Lower Silurian Medina Group and equivalent rock units in Pennsylvania: Pennsylvania Topographic and Geologic Survey, Mineral Resources Report 82, 21 p.

Posamentier, H.W., M.T. Jervey, and P.R. Vail, 1988, Eustatic controls on clastic deposition I conceptual framework, in, C.K. Wilgus, B.S. Hastings, C. Kendall, H.W. Posamentier, C.A. Ross, and J.C. Van Wagoner, eds., Sea level Changes: An Integrated Approach: SEPM Special Publication 42, p. 109-124.

Quinlan, G.M. and C. Beaumont, 1984, Appalachian thrusting, lithospheric flexure, and the Paleozoic stratigraphy of the Eastern Interior of North America: Canadian Journal of Earth Science, v.21, p. 973-996.

Reichle, D., and 19 coauthors, 1999, Carbon Sequestration Research and Develop Washington, D.C., U.S. Department of Energy, Offices of Science and Fossil Energy, 1999, 289 p. <http://www.osti.gov/energycitations/servlets/purl/810722-9s7bTP/native/810722 .PDF>. 
Reineck, H.E. and I.B. Singh, 1980, Depositional sedimentary environments: New York, Springer-Verlag, $549 \mathrm{p}$.

Ross, C.A. \& J.R.P. Ross, 1996, Silurian sea-level fluctuations, in B.J. Witzke, G.A Ludvigson, and J. Day, eds., Paleozoic sequence stratigraphy; Views from the North American craton: Geological Society of America Special Paper, v. 306, p.187-192.

Ryder, R.T., K.L. Aggen, R.D. Hettinger, B.E. Law, J.J. Miller, V.F. Nuccio, W.J. Perry Jr., S.E. Prensky, J.R. SanFilipo, and C.J. Wandry, 1996, Possible continuous-type (unconventional) gas accumulation in the Lower Silurian "Clinton" sands, Medina Group, and Tuscarora Sandstone in the Appalachian basin: a progress report of 1995 project activities: U.S. Geological Survey, Open-File Report 96-42, 82 p.

Ryder, R.T., 2000, Stratigraphic framework and depositional sequences in the Lower Silurian regional oil and gas accumulation, Appalachian basin: from Jackson County, Ohio, through northwestern Pennsylvania, to Orleans County, New York: U.S. Geological Survey Miscellaneous Investigations Series Map I-2726, 2 sheets, pamphlet, 8 p.

Ryder, R.T., 2006, Stratigraphic framework and depositional sequences in the Lower Silurian regional oil and gas accumulation, Appalachian basin: from Licking County, Ohio to Fayette County, West Virginia: U.S. Geological Survey Miscellaneous Investigations Series Map I-2916, 2 sheets, 12 p.

Ryder, R.T. \& W.A. Zagorski, 2003, Nature, origin, and production characteristics of the Lower Silurian regional oil and gas accumulation, central Appalachian basin, United States: American Association of Petroleum Geologist Bulletin, v.87, no.5, p.847-872.

Smosna, R. \& D. Patchen, 1978, Silurian evolution of central Appalachian basin: American Association of Petrloleum Geologist Bulletin, v.62, no.11, p. 2308-2328.

Shumaker, R.C., 1996, Structural history of the Appalachian basin, in J.B. Roen and B.J. Walker, eds., The atlas of major Appalachian gas plays: West Virginia Geological and Economic Survey Publication, v. 25, p. 8-22.

Van der Voo, R., 1988, Paleozoic paleogeography of North America, Gondwana, and intervening displaced terranes: Comparsions of paleomagnetism with paleoclimatology and biogeographical patterns: Geological Society of America Bulletin, v.100, p.311-324.

Van Wagoner, J.C., H.W Posamentier, R.M. Mitchum, P.R. Vail, J.F. Sarg, T.S.Loutit, and J. Hardenbol, J., 1988, An overview of sequence stratigraphy and key definitions, in C.K. Wilgus, C.A. Ross, H.W. Posamentier, Sea-level changes-An integrated approach: Society of Economic Paleontologists and Mineralogists Special Publication 42, p. 29-45. 
Van Wagoner, J.C., R.M. Mitchum, K.M. Campion, and V.D. Rahmanian, 1990, Siliciclastic sequence stratigraphy in well logs, cores, and outcrops: American Association of Petroleum Geologists Methods in Exploration Series No.7, 55 p.

Walker, R.G., 1992, Facies, facies models and modern stratigraphic concepts in R.G. Walker and N.P. James, eds., Facies Models: Response to Sea Level Changes: St. John's, Newfoundland, Geological Association of Canada, p. 1-14.

Wescott, W.A., 1982, Nature of porosity in Tuscarora Sandstone (Lower Silurian) in the Appalachian basin: Oil and Gas Journal, v.80, no.34, p.159-173.

Wheeler, H.E., 1963, Post-Sauk and pre-Absaroka Paleozoic stratigraphic patterns in North America: American Association of Petroleum Geology Bulletin, v.64, p. 1497-1526.

Whisonant, R.C., 1977, Lower Silurian Tuscarora (Clinch) dispersal patterns in western Virginia: Geological Society of America Bulletin, v.88, p.215-220.

Wilson, B.W. and R.H. Nanz, 1959, Sand conditions as indicated by the self-potential log: EPRM Memorandum Report 51, Shell Development Company, Houston Texas.

Woodward, H.P., 1941, Silurian system of West Virginia: West Virginia Geological Survey, v.21, $627 \mathrm{p}$.

Woodrow, D.L, J.M Dennison, F.R. Ettensohn, W.T. Sevon, and W.T. Kirchgasser, 1988, The Middle and Upper Devonian of the Appalachian Basin, United States, in N.J. Mcmillan, A.F. Embry, D.J. Glass, eds., Devonian of the World, Proceedings of the Second International Symposium on the Devonian System, Canadian Society of Petroleum Geologists Memoir 14, v. 1, p. 277-301.

WVGES (West Virginia Geological and Economic Survey), 2013, Samples description from F.D. Caldwell No. 42 well (API\# 47099000465), <http://www.wvgs.wvnet.edu> Accessed August 27, 2012.

Yeakel, L.S., 1958, Early Silurian and late Ordovician paleocurrents in the central Appalachians (abs.): Geological Society of America Bulletin, v. 69, p. 1667-1668

Yeakel, L.S., 1962, Tuscarora, Juniata, and Bald Eagle paleocurrents and paleogeography in the central Appalachians: Geological Society of America Bulletin, v.73, p. 1515-1539. 
APPENDIX I: Regional Lithostratigraphic Correlations 
The lower, middle, and upper members of the Tuscarora Sandstone were correlated using approximately 175 wells with geophysical logs within the study area. Gamma-ray, neutron and density logs were the primary logs used for correlations. In addition to the units correlated above, three units in the overlying Rose Hill Shale in West Virginia were correlated for reference. These units are in ascending order: the Upper Cabot Head Shale, the Oldham Limestone (datum) and the Lulbegrud Shale; these units are formally recognized in Ohio within the Clinton Group. Within the study area, 6 dip-oriented and 5 strike-oriented lines of section were created in order to show the subsurface stratigraphic relationships and geometries of individual members (Figure 58). The gamma-ray curve is located in track one with a scale of 0$250 \mathrm{API}$ and in track two is the bulk density log (red curve, scaled at $2-3 \mathrm{~g} / \mathrm{cm}^{3}$ ) and neutron porosity curve (blue curve, scaled at $30 \%$ to $-10 \%$ ).

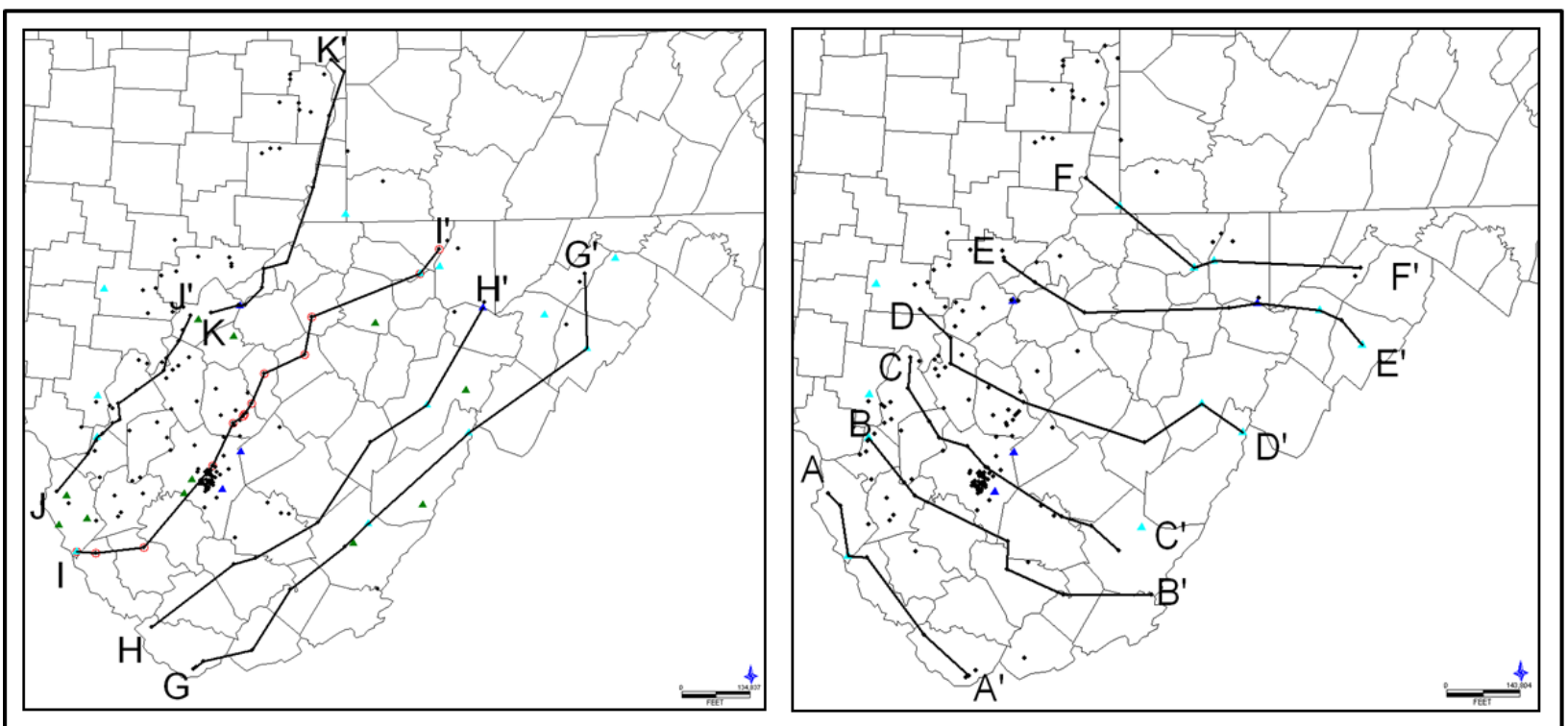

Figure 58: Orientation of selected eleven cross-sections in the study area. Letters A-F (right) are oriented along-dip and letters G-K (left) are oriented along-strike. 


\section{Dip-oriented cross sections}

In southern and central West Virginia, the upper member thins considerably from east to west. This thinning trend also coincides with the appearance of the lower and middle members. As the upper member thins, there is a thickening of the middle and lower members (Figures 5961). In the northeastern region of the study area, the thickest intervals of the upper member occur. Additionally, the lower and middle members are present as opposed to the southeastern study area (Figures 61 and 62).

\section{Strike-oriented cross sections}

The upper member thickens significantly to the northeast and generally is a clean sandstone and the lower and middle members are absent to the southeast but are present to the north (Figures 61-63). Across the study area to the west, the upper member thins, but continues to thicken to the north and the lower and middle members are also present throughout the cross sections. Along the western margin of the state the upper member is at its thinnest, has a higher shale to sandstone ratio, while the lower and middle member are considerably thicker than in the east (Figures 61-63). 


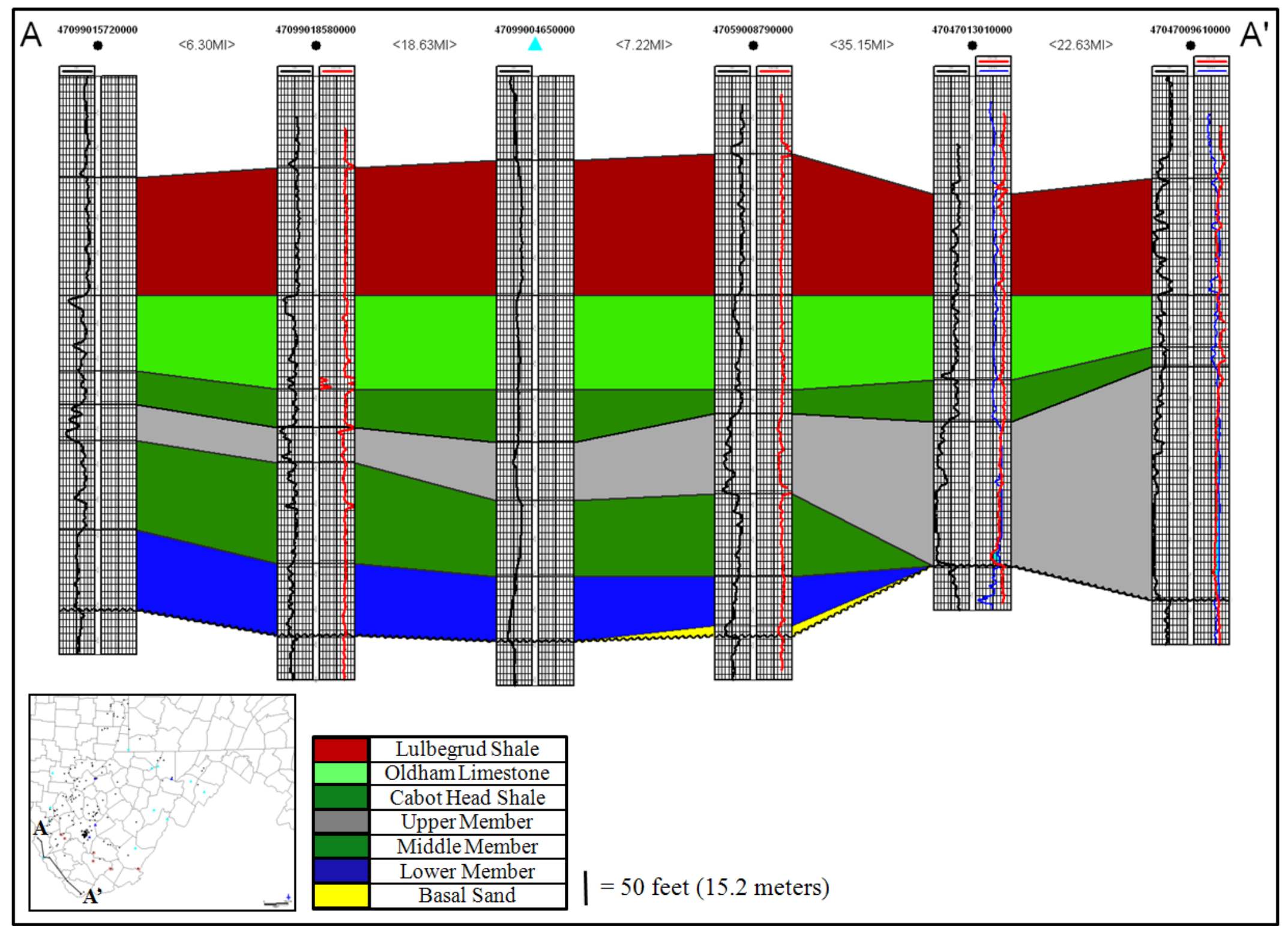

Figure 59: Cross section A-A' in southern West Virginia with the top of the Oldham Limestone as a datum. The upper member thins significantly to the west. The lower and middle member are absent in the two wells to the east but are present to the west and thicken as the upper member thins. 


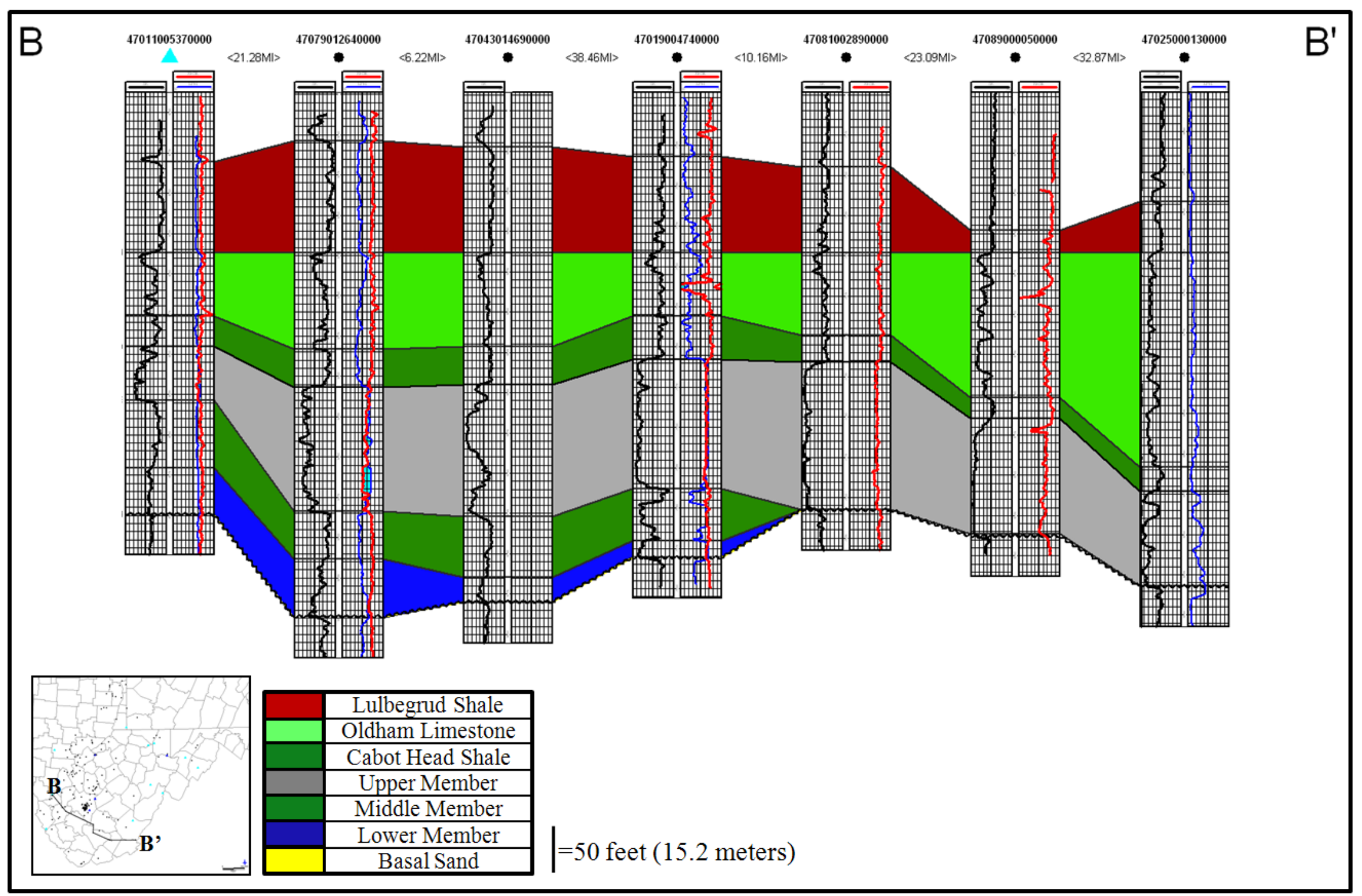

Figure 60: Cross section B-B' with the top of the Oldham Limestone as a datum. Similar to Figure 24, this cross section shows the thinning of the upper member to the west as well as increased shale content. The lower and middle member are also absent in the east and appear to the west and thicken as the upper member thins. 


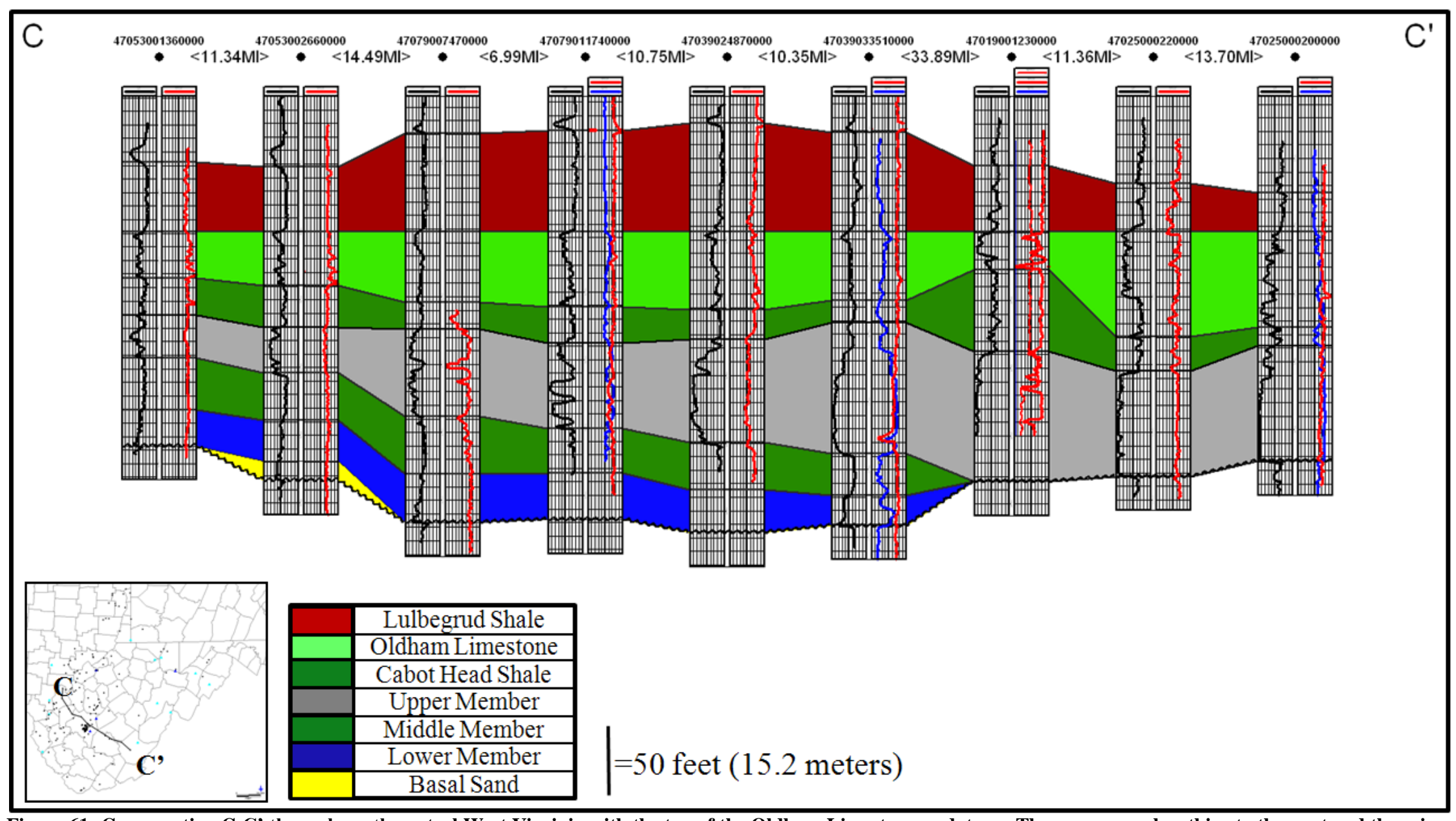

Figure 61: Cross-section C-C' through south-central West Virginia with the top of the Oldham Limestone as datum. The upper member thins to the west and there is a noticeable increase in the shale content. The lower and middle members are absent to the east, but appear to the west and thicken as the upper member thins. 


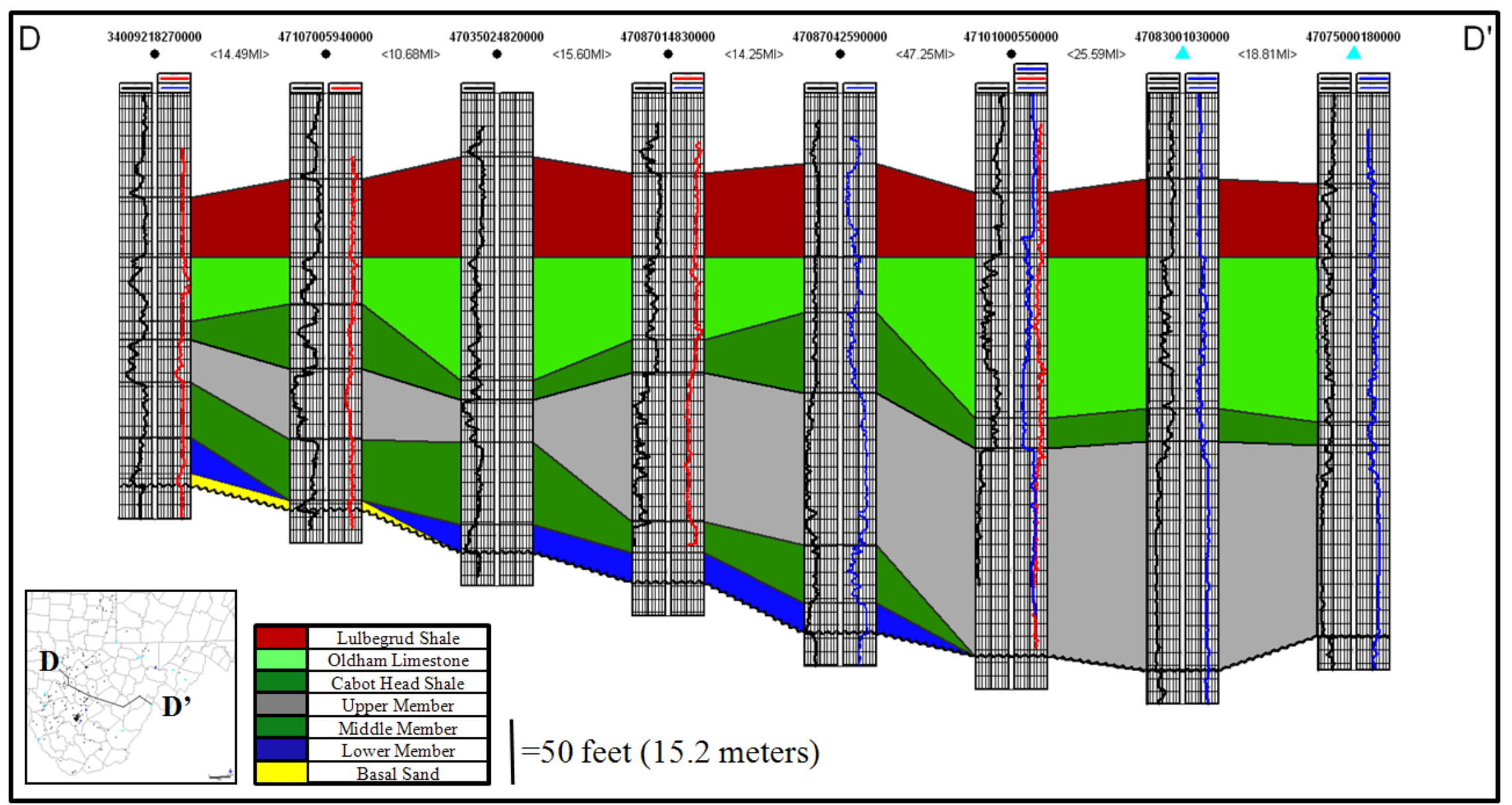

Figure 62: Cross section D-D' through central West Virginia with the top of the Oldham Limestone as a datum. In this more northern cross section the upper member is thickening in the east, but still thins significantly to the west. The lower and middle members are again absent to the east and appear in the west and thicken as the upper member thins. 


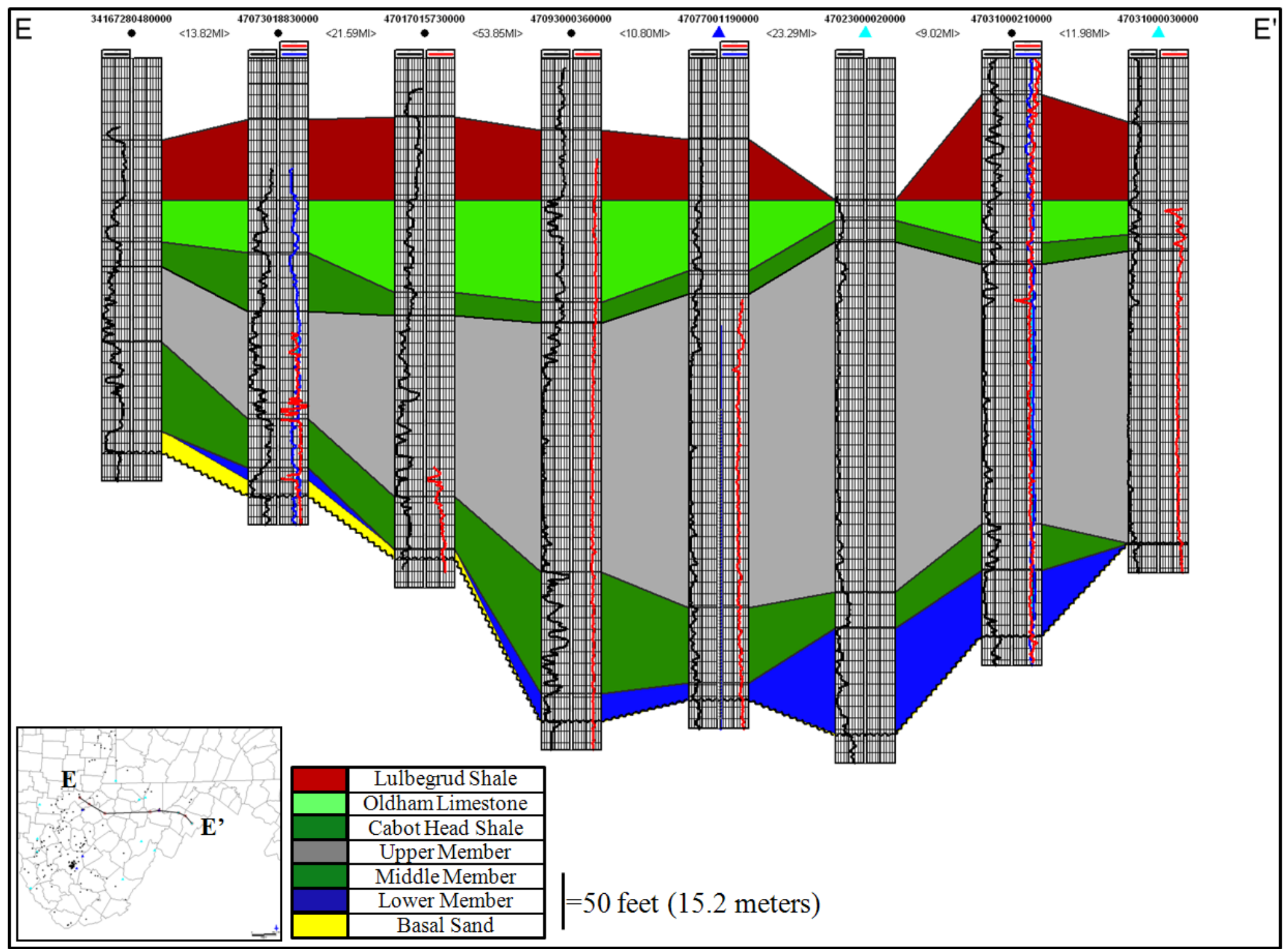

Figure 63: Cross section E-E' with the top of the Oldham Limestone as a datum in northern West Virginia. Note in this region that the lower and middle members are present in the east and the upper member is significantly thicker than the upper member in the south. The upper thins to the west and the amount of shale increases as well while the lower and middle members thicken to the west. 


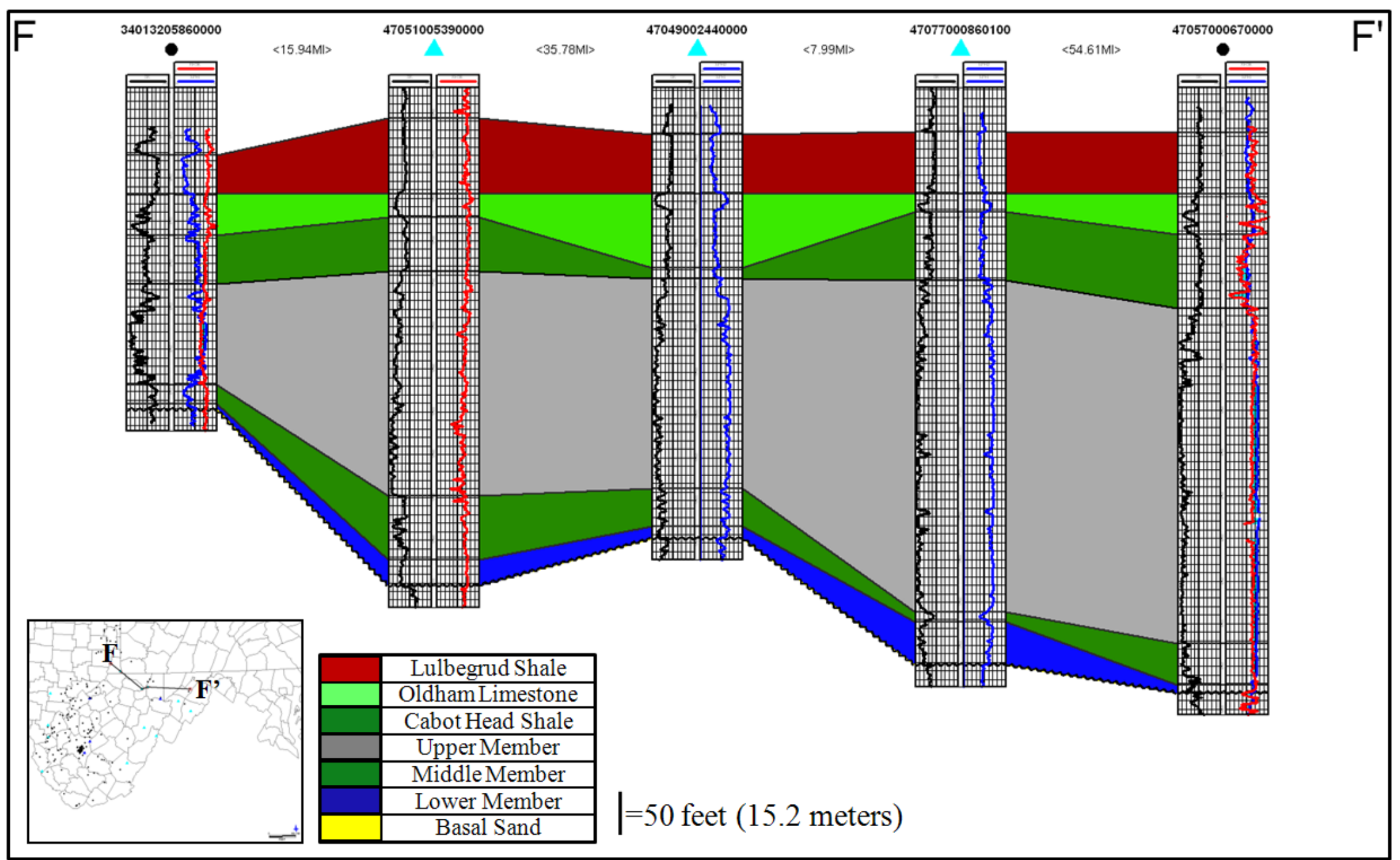

Figure 64: Cross section F-F' in northern West Virginia with the top of the Oldham Limestone as a datum. Like Figure 28, the lower and middle members are present in the east. The upper member thins to the west. 


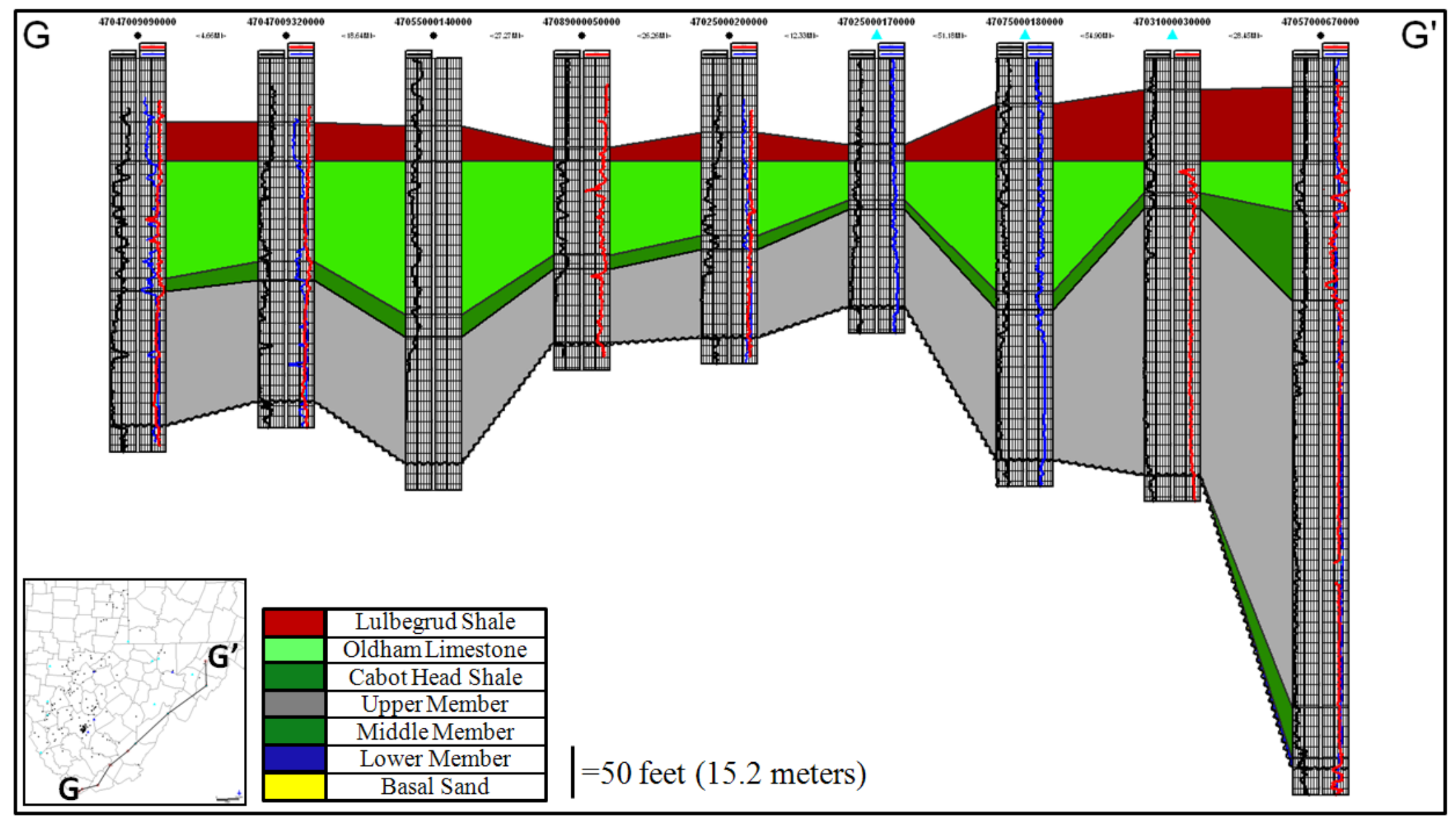

Figure 65: Cross section G-G' through the eastern margin of the study area. The upper member thickens to the north and overall is a very clean sandstone. The lower and middle members are absent throughout most of this section, but are present in the northeast. Top of the Oldham Limestone is used as a datum. 


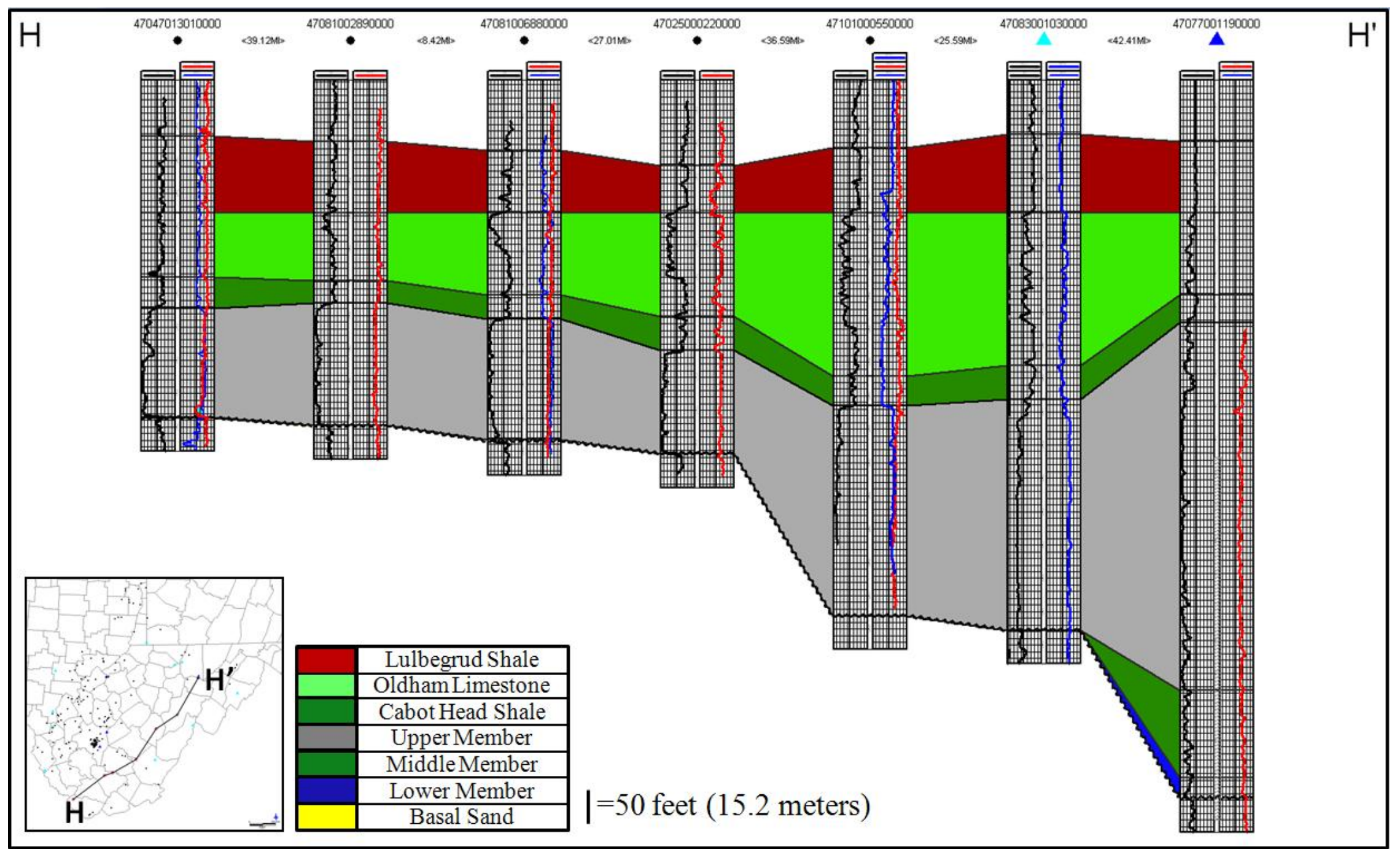

Figure 66: Cross section H-H' with the top of the Oldham Limestone as a datum showing an increase in thickness of the very clean upper member to the north. The lower and middle member are also present in the northeast. 


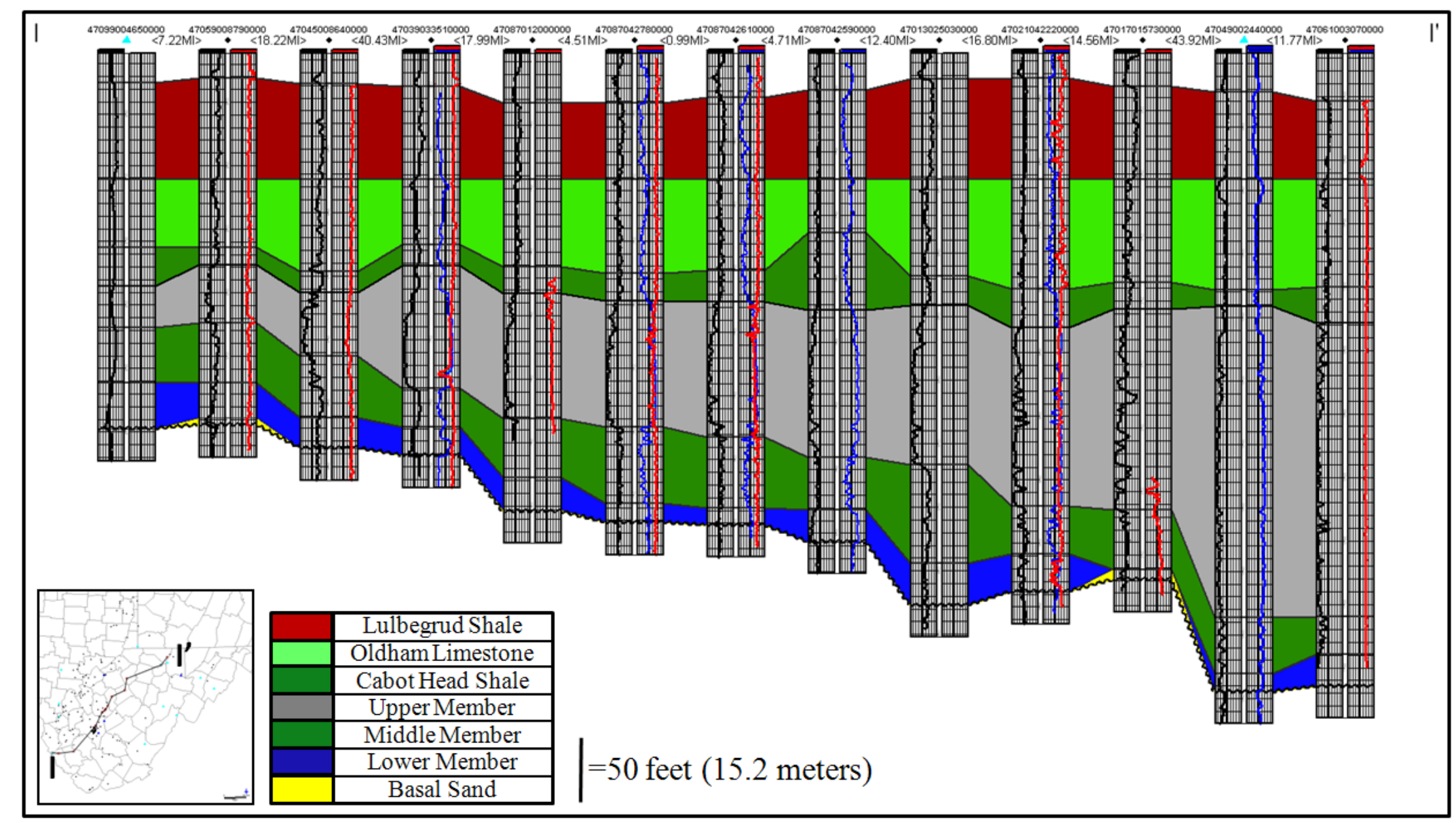

Figure 67: Cross section I-I' through the central study area. The amount of shale in the upper member is variable and overall it thickens to the north. Note the presence of the lower and middle members throughout the section. Top of the Oldham Limestone is used as a datum. 


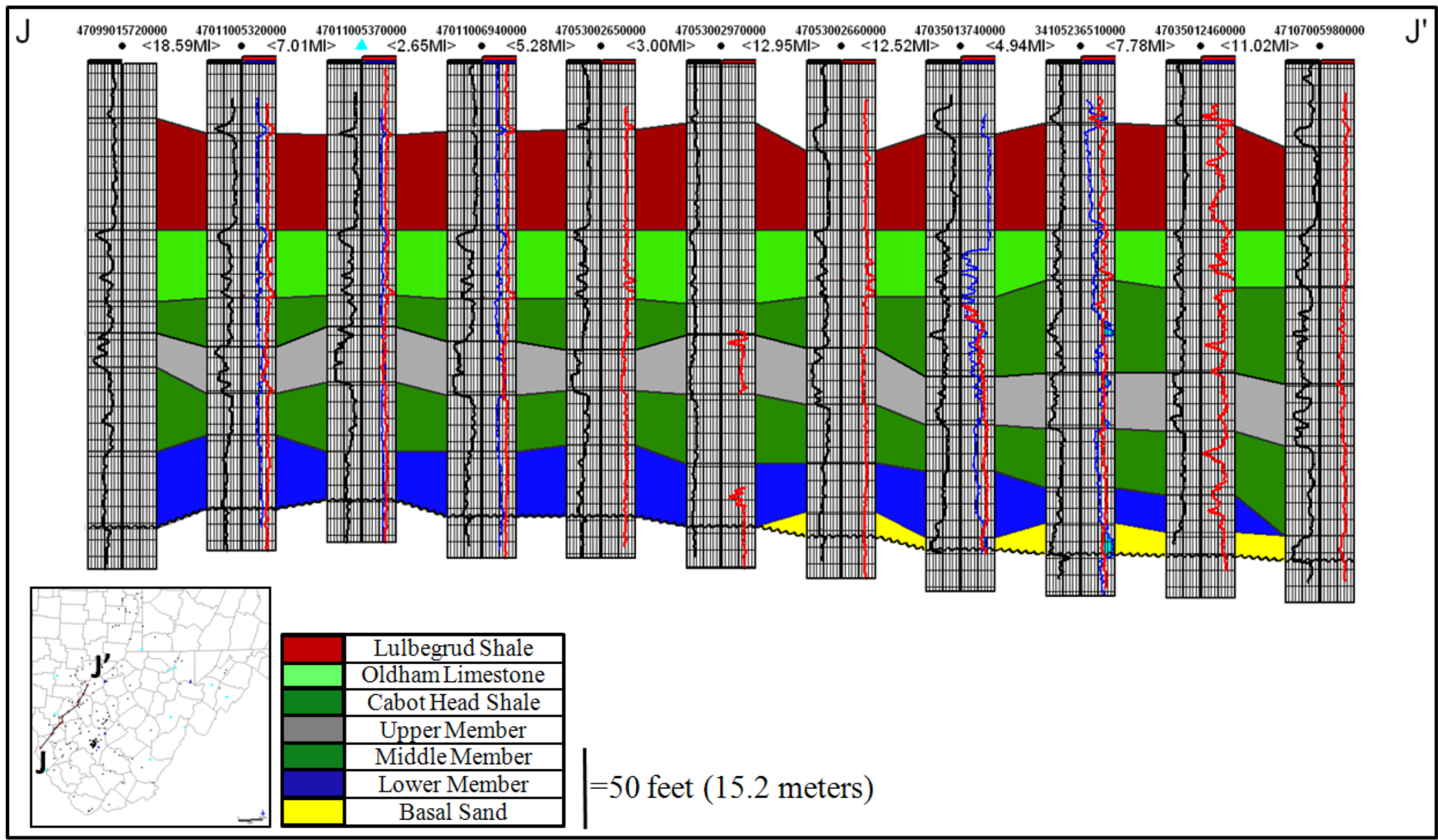

Figure 68: Cross section J-J' along the western margin of the study area. The units along strike display relatively uniform thickness along section. The amount of shale in the upper member is also more noticeable in this region. Top of the Oldham Limestone is used as a datum. 


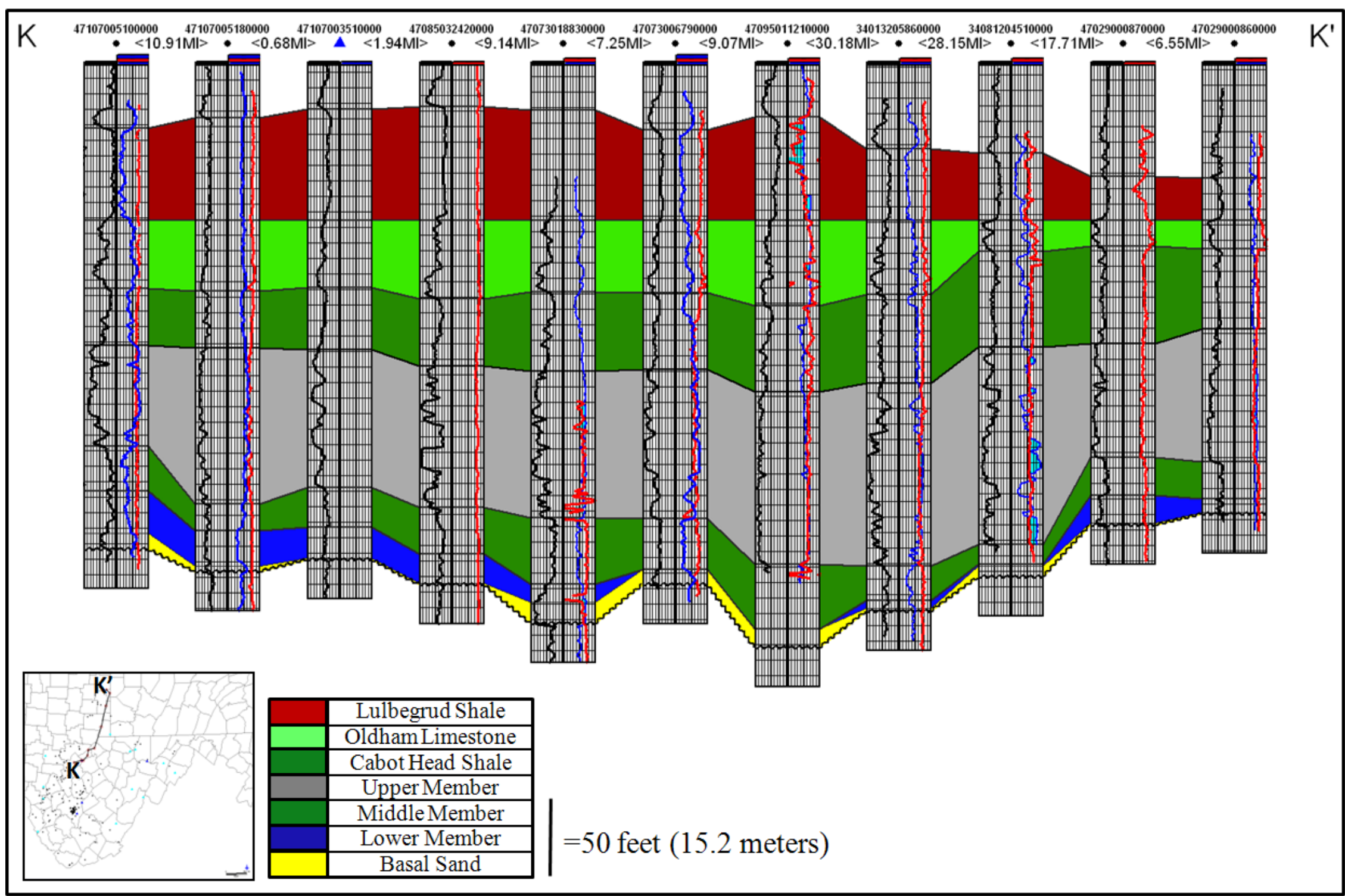

Figure 69: Cross section K-K' through the western margin of the study area. The upper member is thicker than in the south and displays relatively consistent thickness. Note the increased amount of shale in this region. Top of the Oldham Limestone is used as a datum. 
APPENDIX II: Sample Descriptions 
Sample Locations

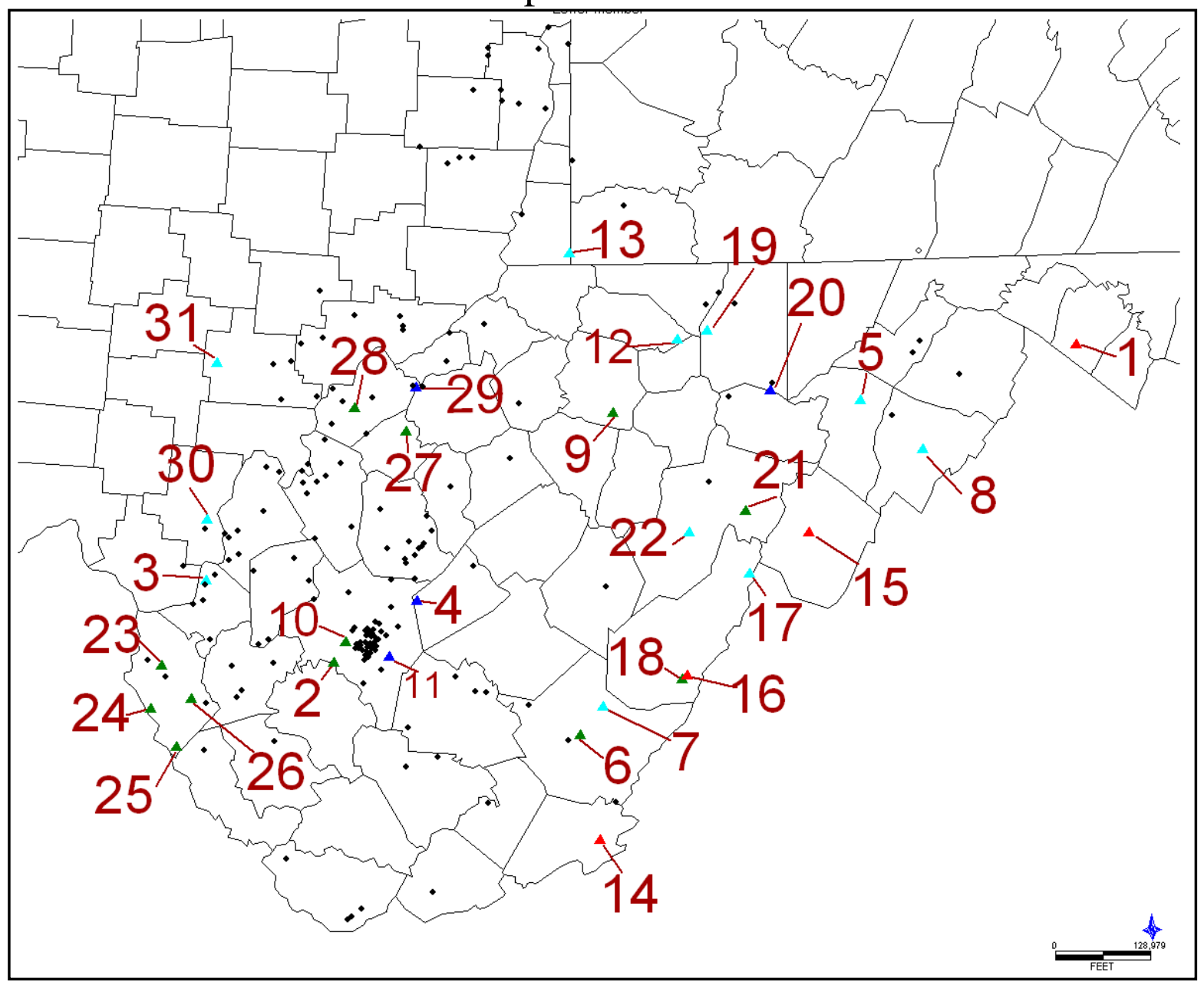


Sample List

\begin{tabular}{|c|c|c|c|c|c|}
\hline Sample & County (Number) & API & Type & $\log$ & Source (Year) \\
\hline 1 & Berkeley (03) & N/A & Outcrop & NO & Folk (1960) \\
\hline 2 & Boone (05) & 47005004020000 & Cuttings & NO & WVGES \\
\hline 3 & Cabell (11) & 47011005370000 & Cuttings & YES & Lukasik (1988) \\
\hline 4 & Clay (15) & 47015005130000 & Core & NO & WVGES \\
\hline 5 & Grant (23) & 47023000020000 & Cuttings & $\mathrm{NO}$ & Diecchio (1985) \\
\hline 6 & Greenbrier (25) & 47025000020000 & Cuttings & NO & WVGES \\
\hline 7 & Greenbrier (25) & 47025000170000 & Cuttings & YES & Diecchio (1985) \\
\hline 8 & Hardy (31) & 47031000030000 & Cuttings & YES & Diecchio \\
\hline 9 & Harrison (33) & 47033000790000 & Cuttings & $\mathrm{NO}$ & WVGES \\
\hline 10 & Kanawha & 47039006620000 & Cuttings & $\mathrm{NO}$ & WVGES \\
\hline 11 & Kanawha $(39)^{*}$ & 47039027510000 & Core & YES & Bruner (1983) \\
\hline 12 & Marion (49) & 47049002440000 & Cuttings & YES & Diecchio (1985) \\
\hline 13 & Marshall (51) & 47051005390000 & Cuttings & YES & Diecchio (1985) \\
\hline 14 & Monr & N/A & Outcrop & $\mathrm{NO}$ & Diecchi \\
\hline 15 & Pendlet & N/A & Outcrop & $\mathrm{NO}$ & Diecchic \\
\hline 16 & Pocahontas (75) & N/A & Outcrop & $\mathrm{NO}$ & Diecchio (1985) \\
\hline 17 & Pocahor & 47075000180000 & Cuttings & YES & Diecchi \\
\hline 18 & Pocahontas (75) & 47075000210000 & Cuttings & NO & Diecchio (1985) \\
\hline 19 & Preston (77) & 47077000860000 & Core & YES & Diecchio (1985) \\
\hline 20 & 7) & 47077001190000 & Cuttings & YES & Castle (1998) \\
\hline 21 & Randolph (83) & 47083001010000 & Cuttings & $\mathrm{NO}$ & Diecchio (1985) \\
\hline 22 & Randolph (83) & 47083001030000 & Cuttings & YES & Diecchio (1985) \\
\hline 23 & Wayne (99) & 47099001460000 & Cuttings & $\mathrm{NO}$ & WVGES \\
\hline 24 & Wayne ( & 47099001620000 & Cuttings & $\mathrm{NO}$ & WVGES \\
\hline 25 & Wayne (99) & 47099004650000 & Cuttings & NO & WVGES \\
\hline 26 & Wayne & 47099005590000 & Cuttings & $\mathrm{NO}$ & WVGES \\
\hline 27 & Wirt (105) & 47105002960000 & Cuttings & NO & WVGES \\
\hline 28 & Wood (107) & 47107000990000 & Cuttings & NO & WVGES \\
\hline 29 & Woo & 47107003510000 & Core & YES & WVGES \\
\hline 30 & Athens (09) & 34009214310000 & Cuttings & YES & Lukasik (1988) \\
\hline 31 & Gallia (53) & 34053201810000 & Cuttings & YES & Lukasik (1988) \\
\hline
\end{tabular}

*Description is located on page 49 in main body 


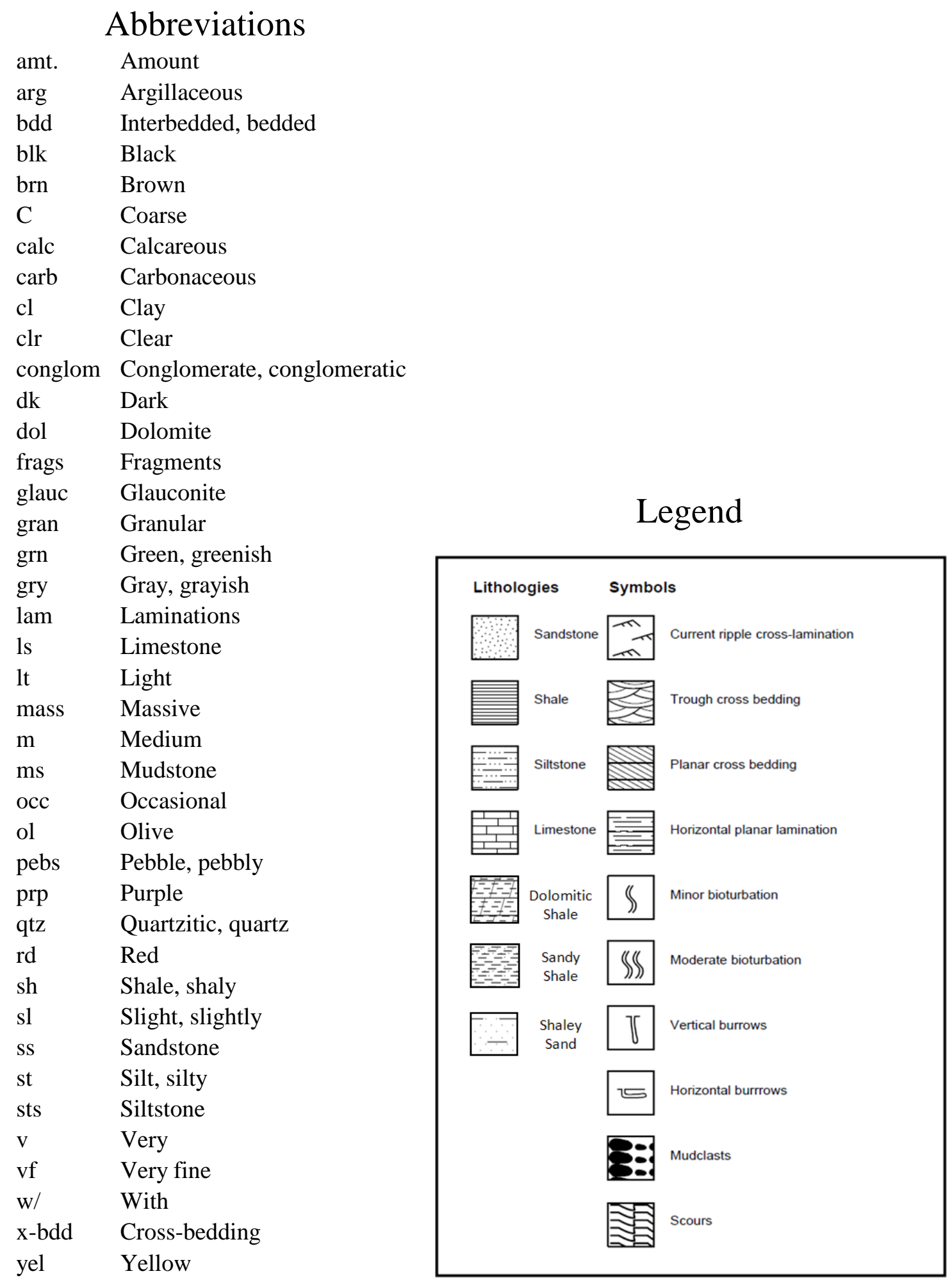




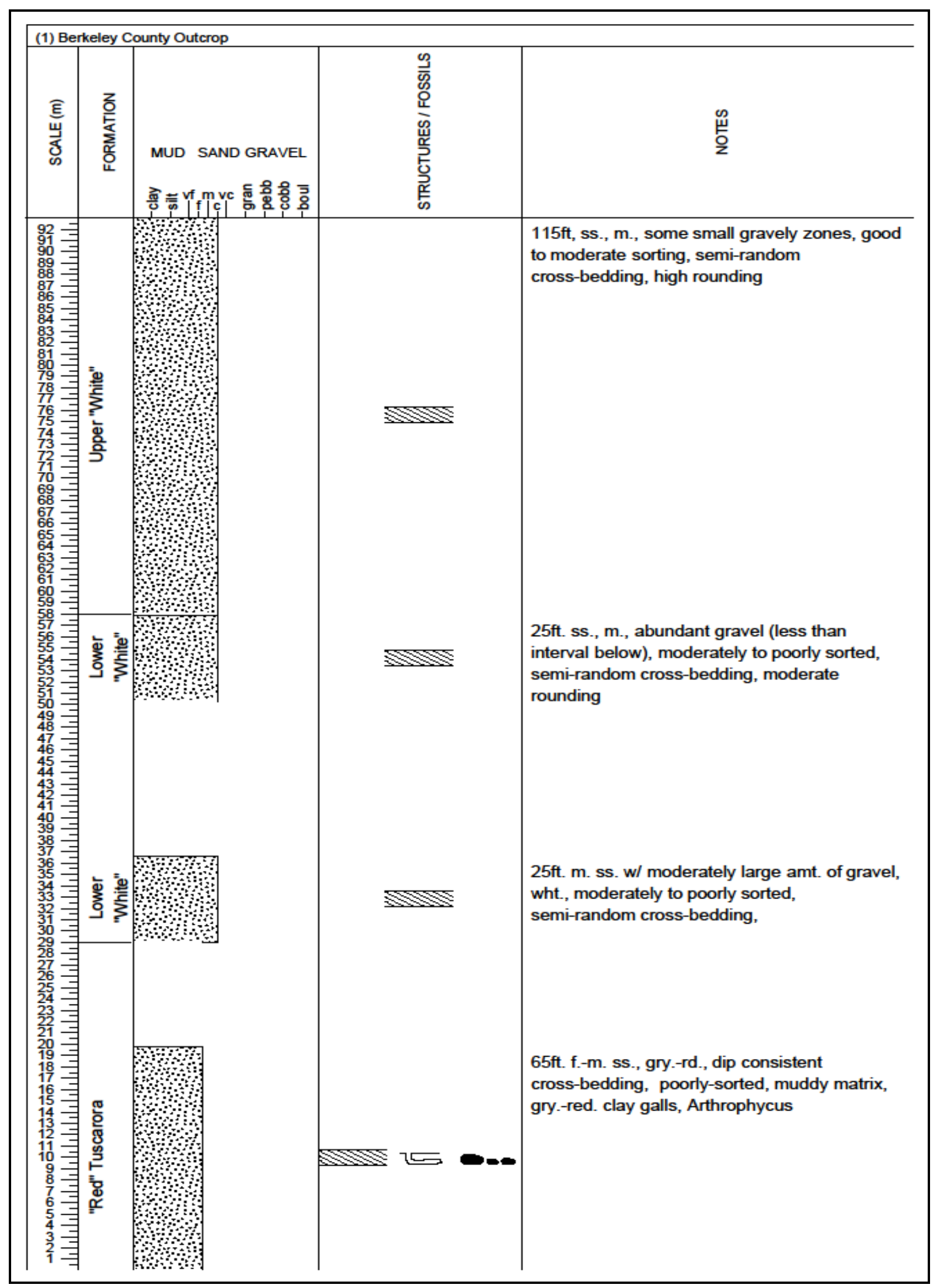




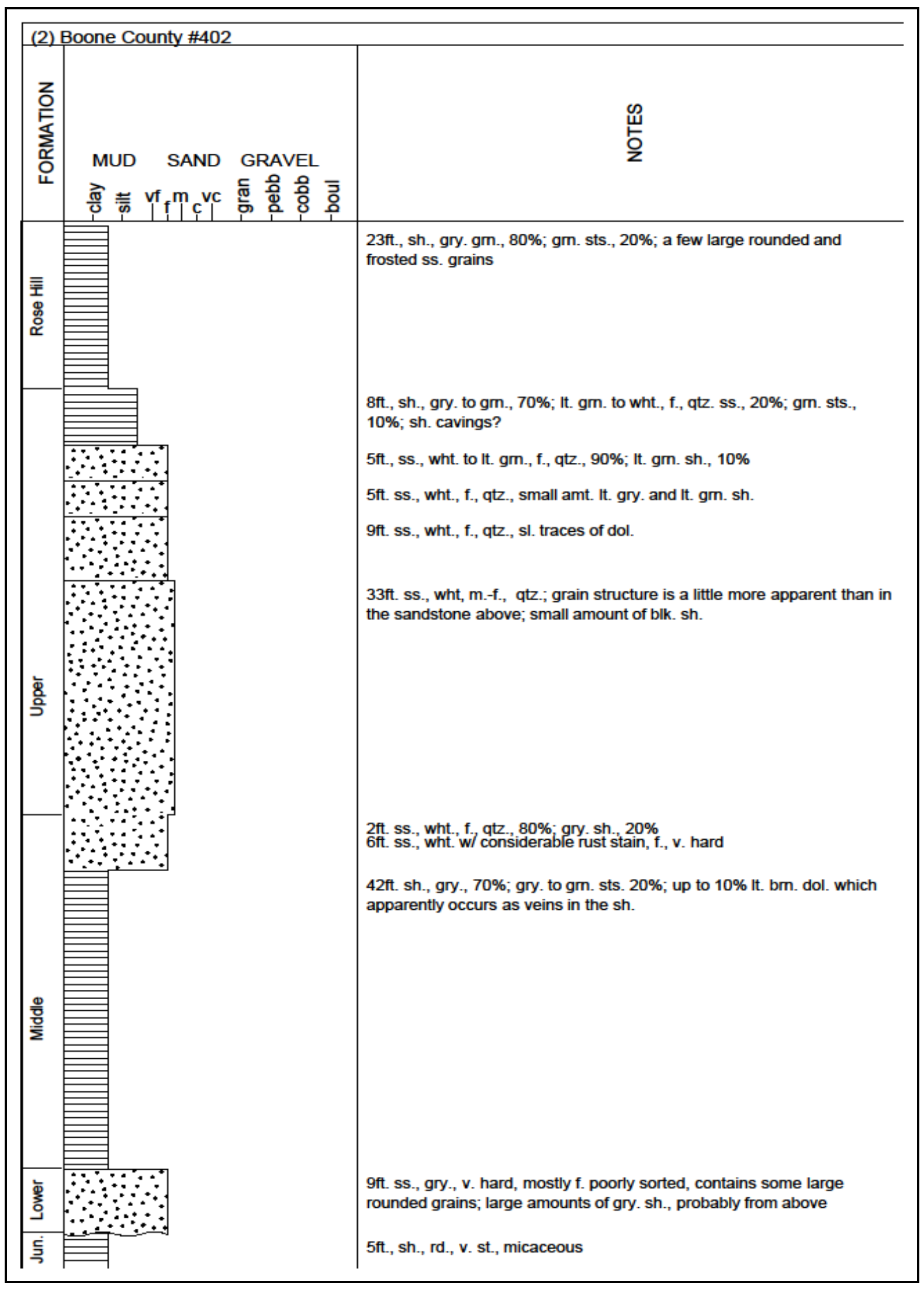




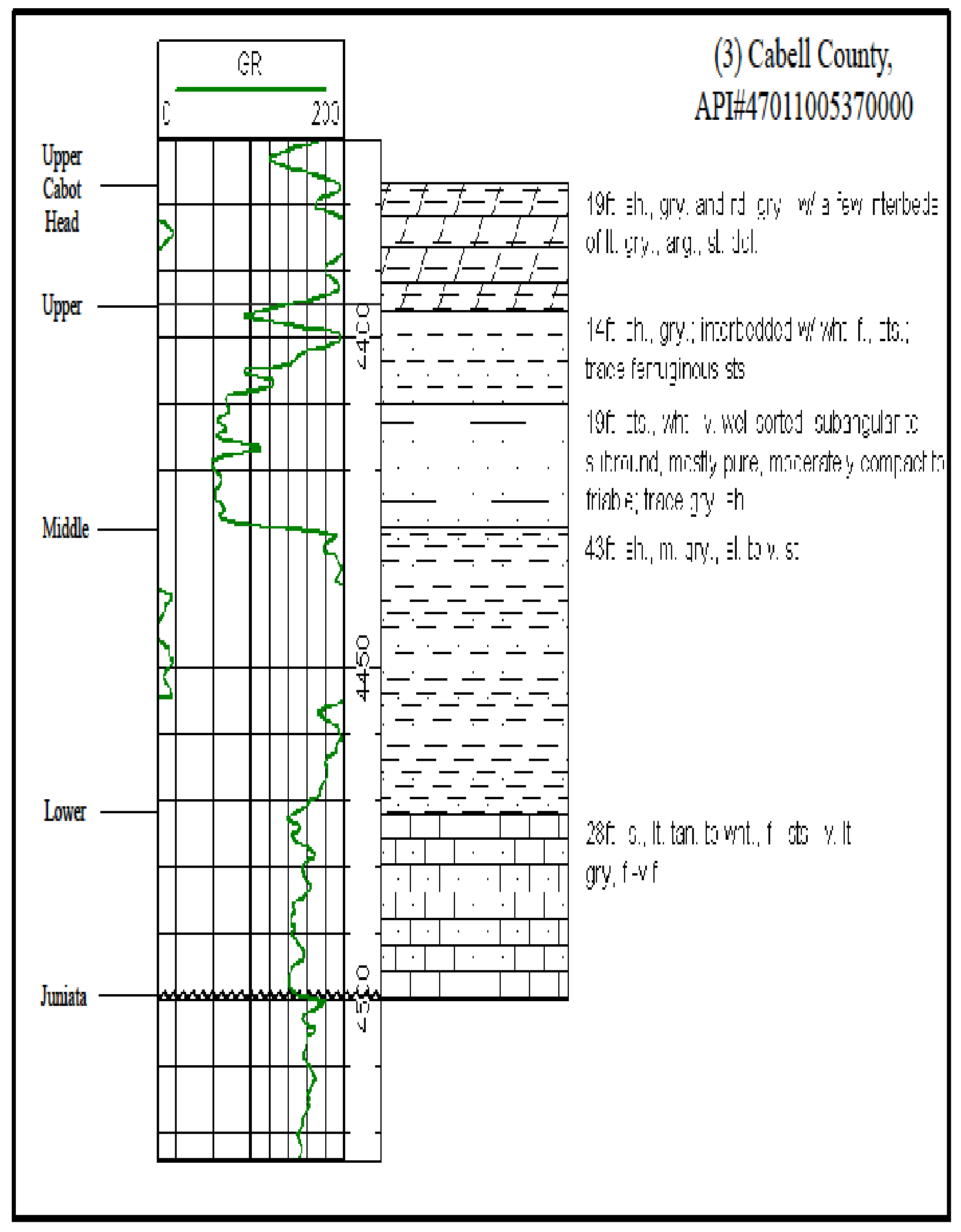




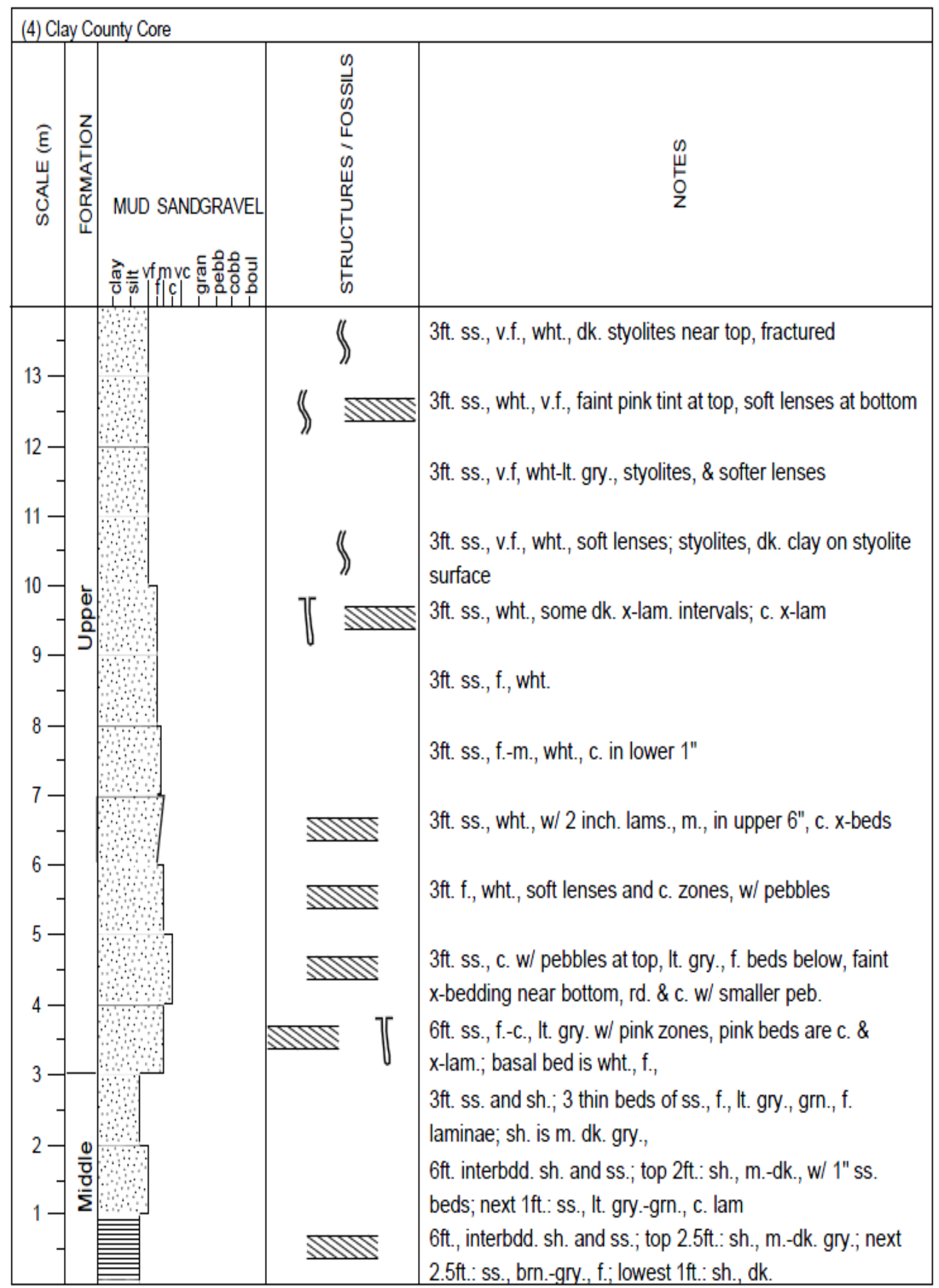




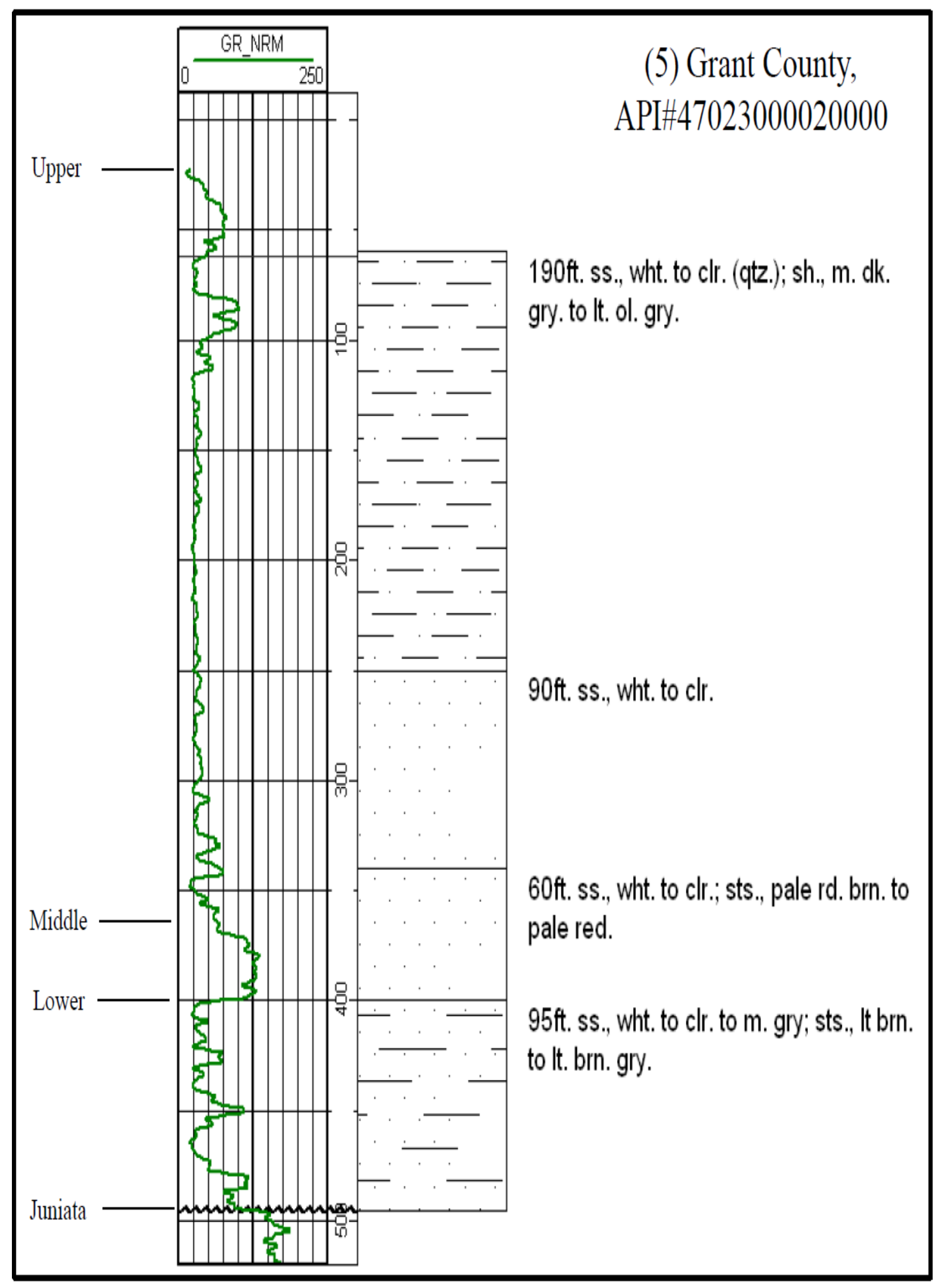




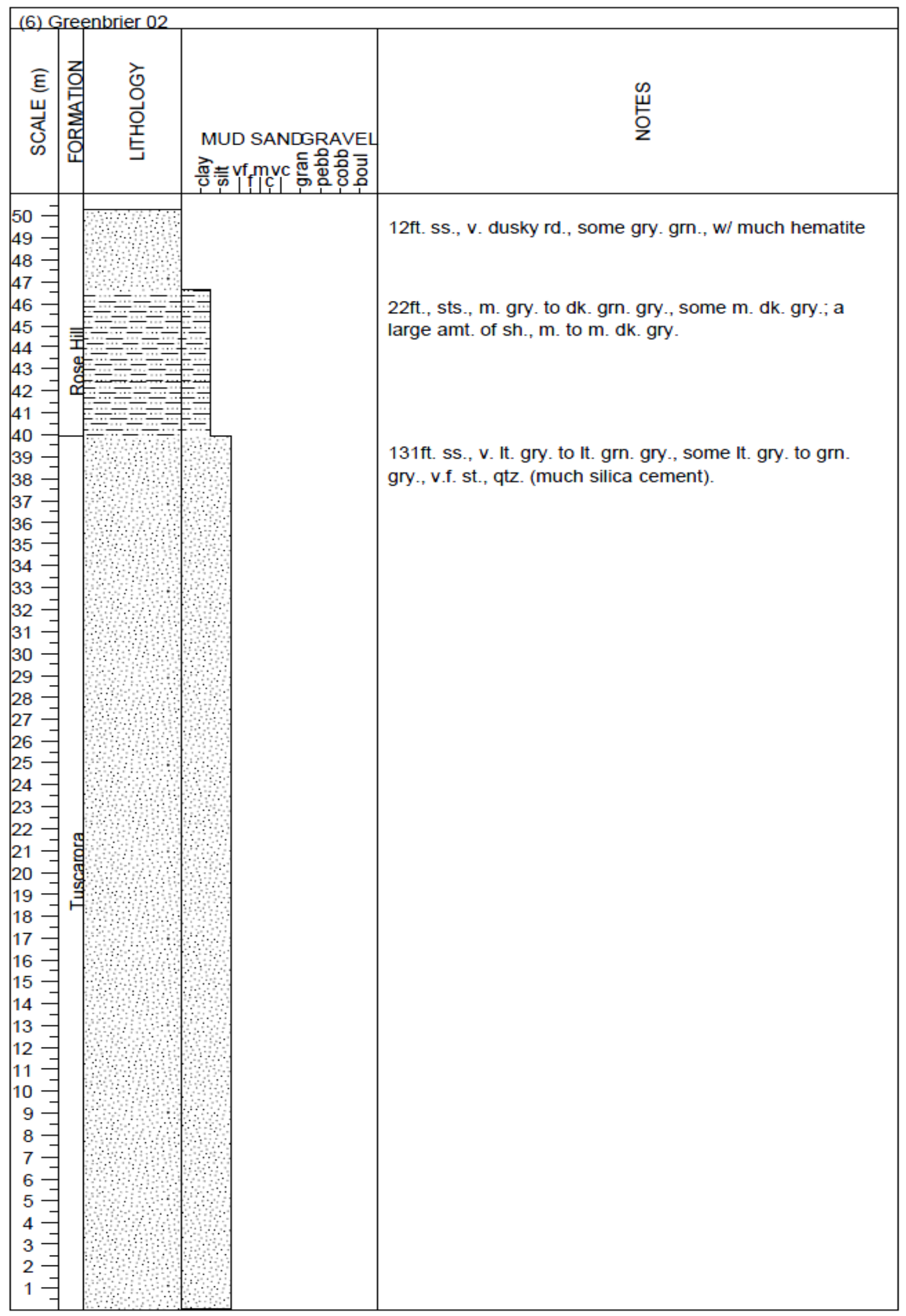




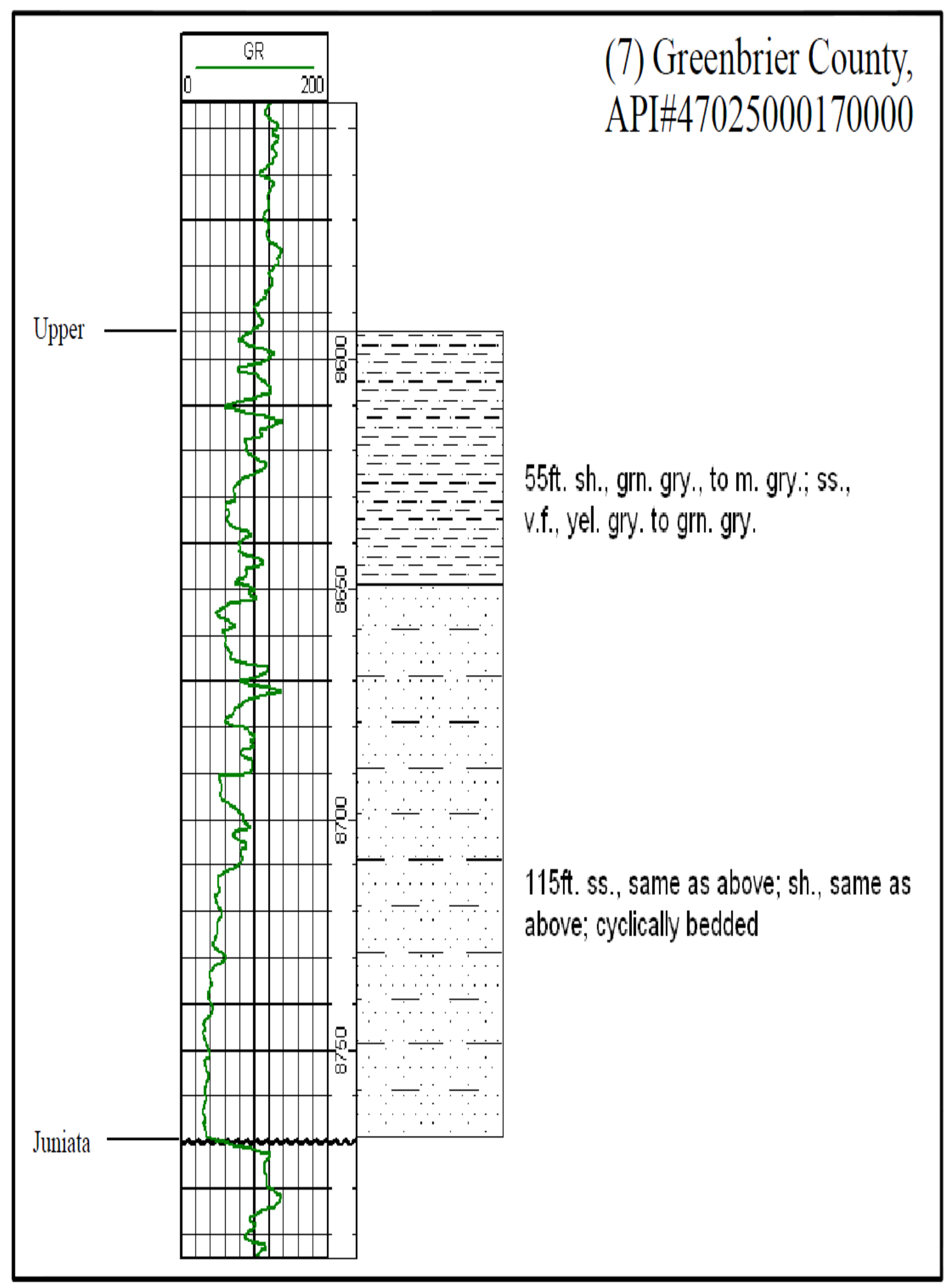




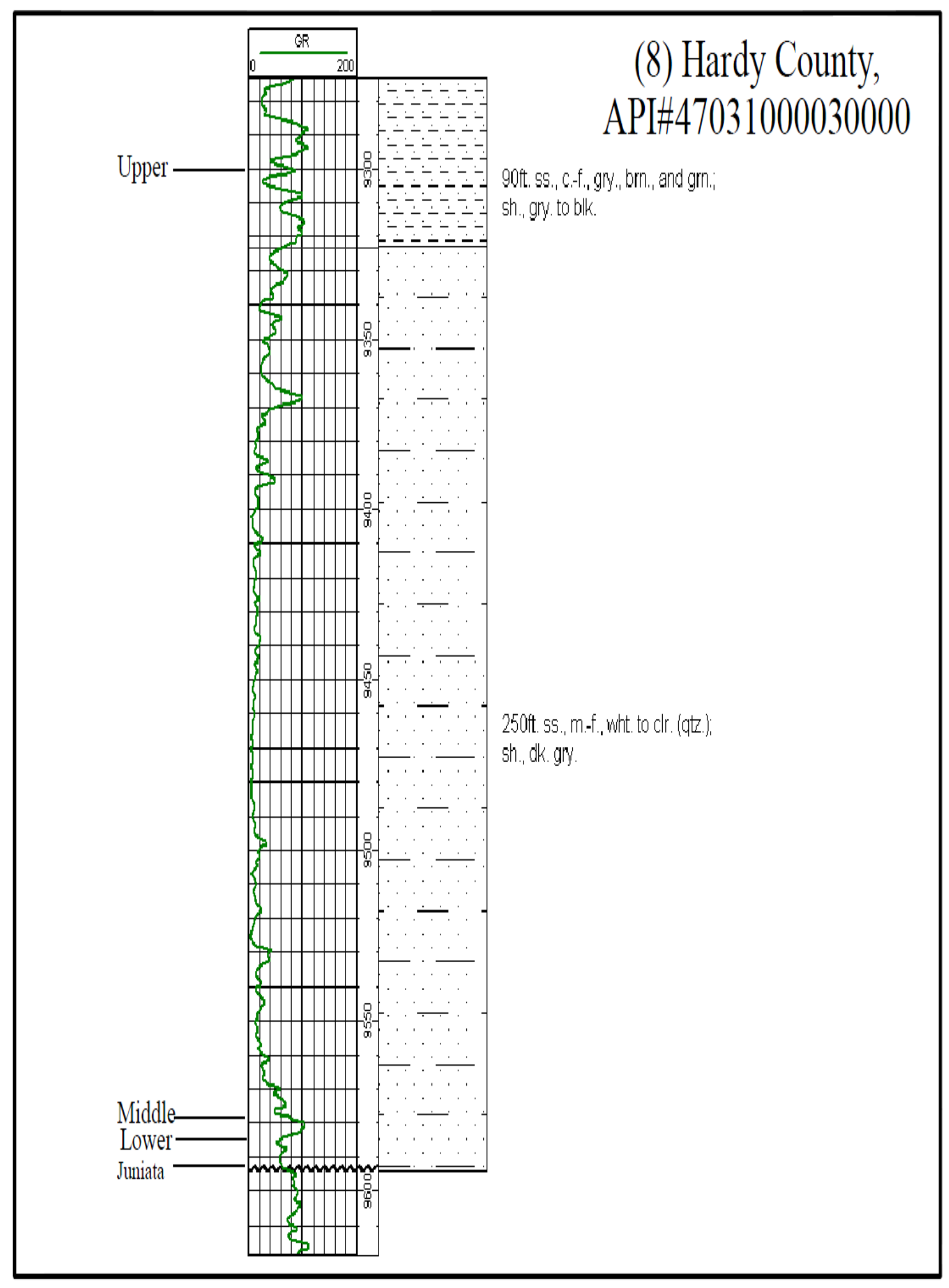




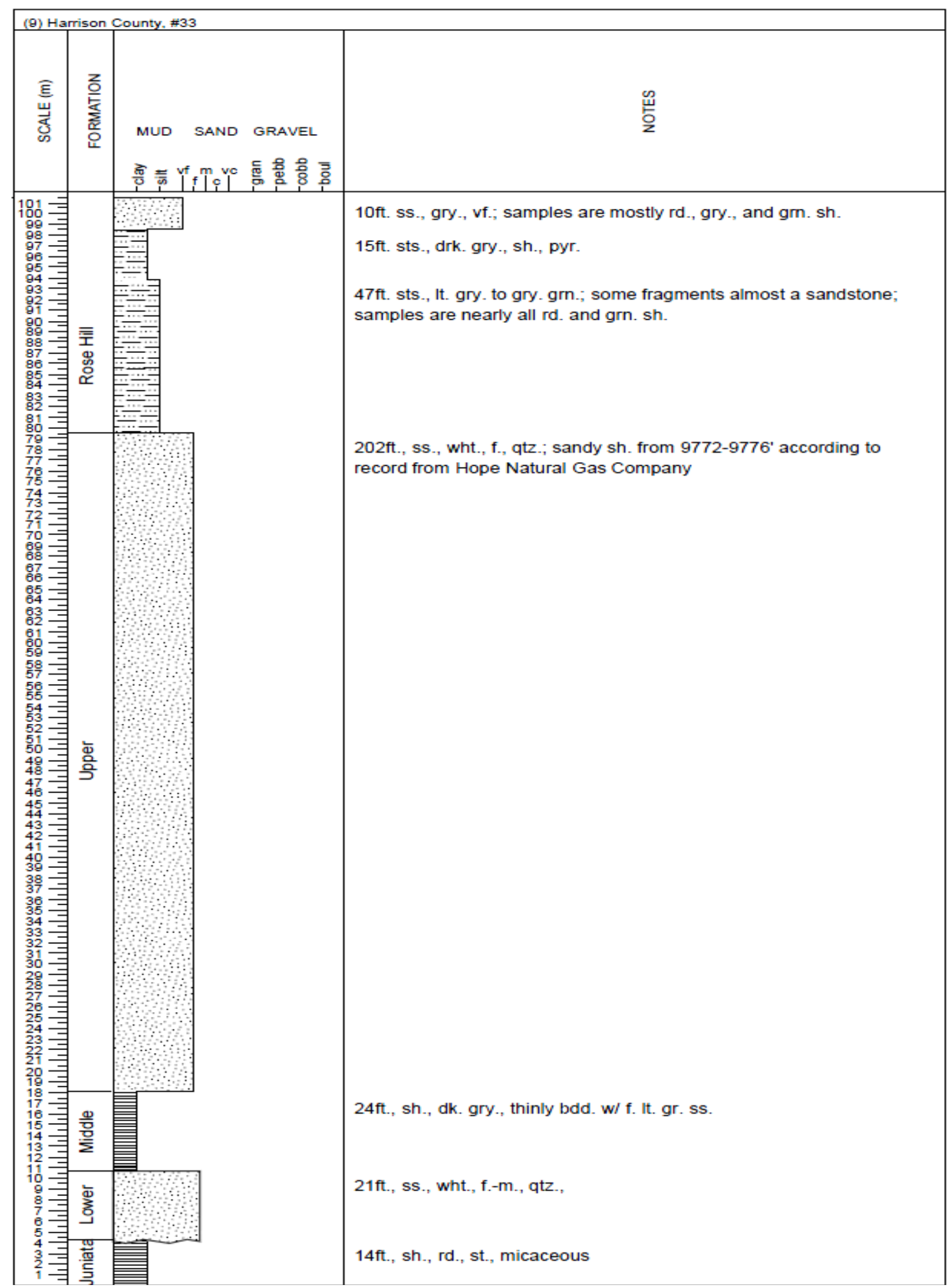




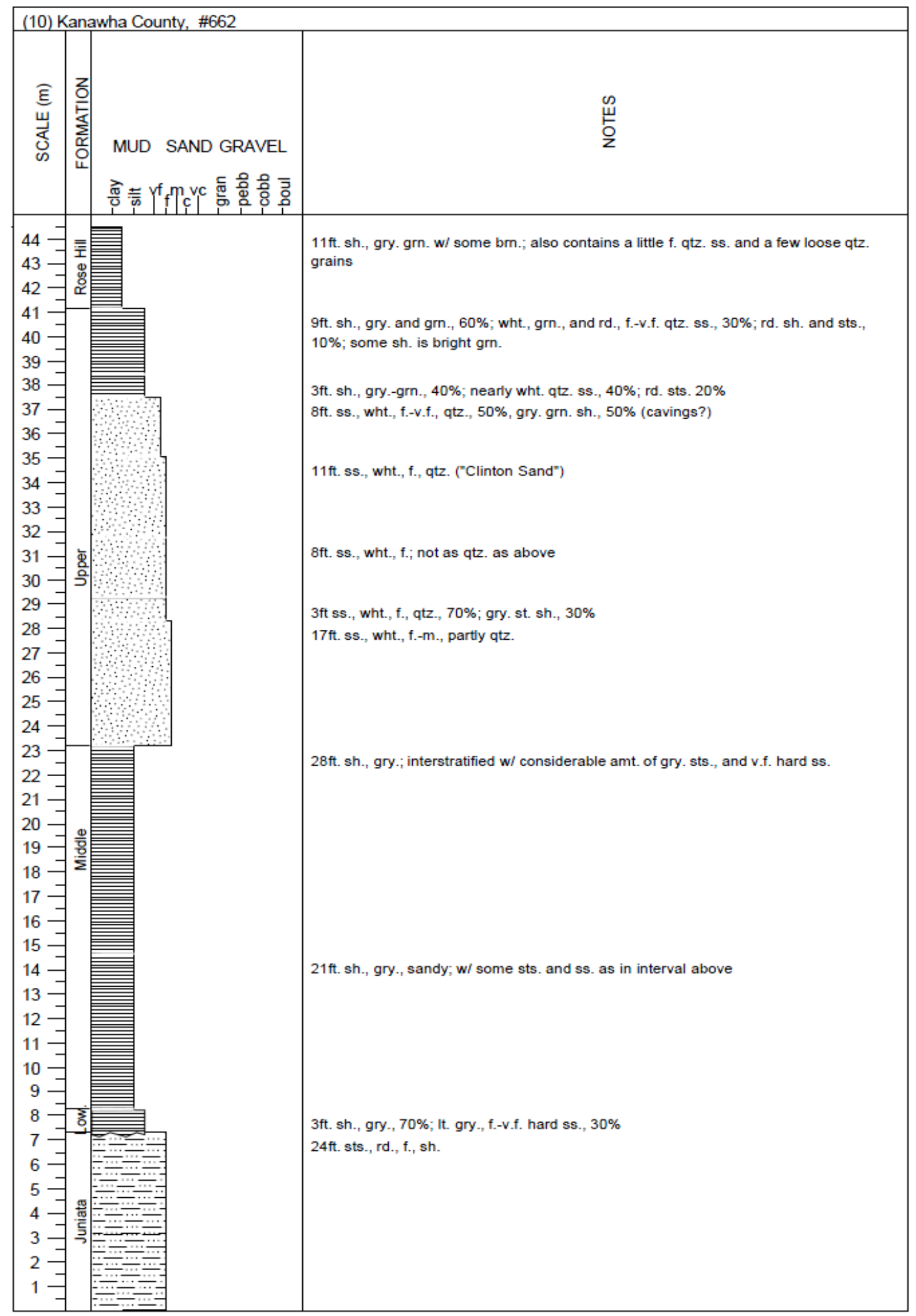




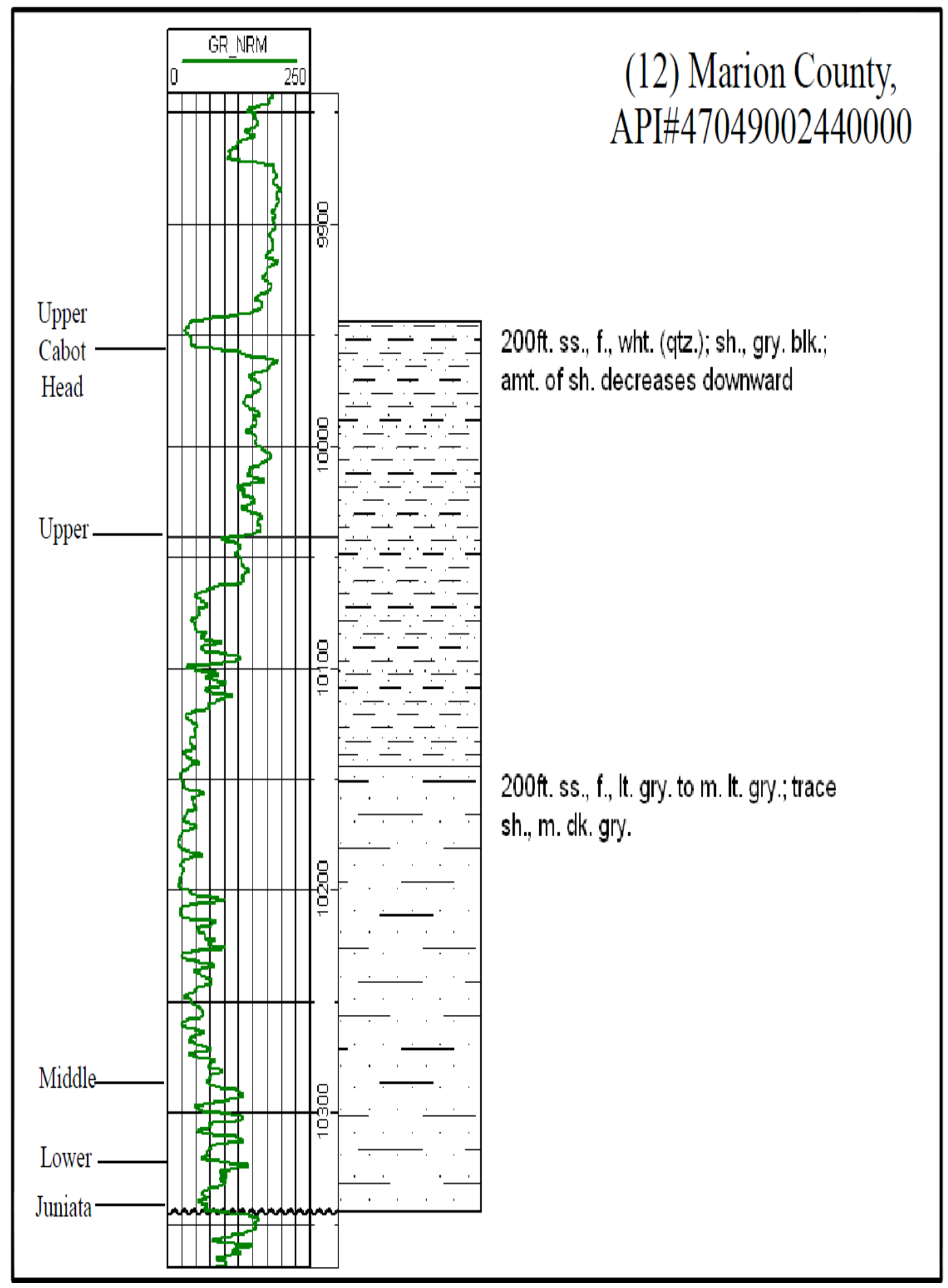




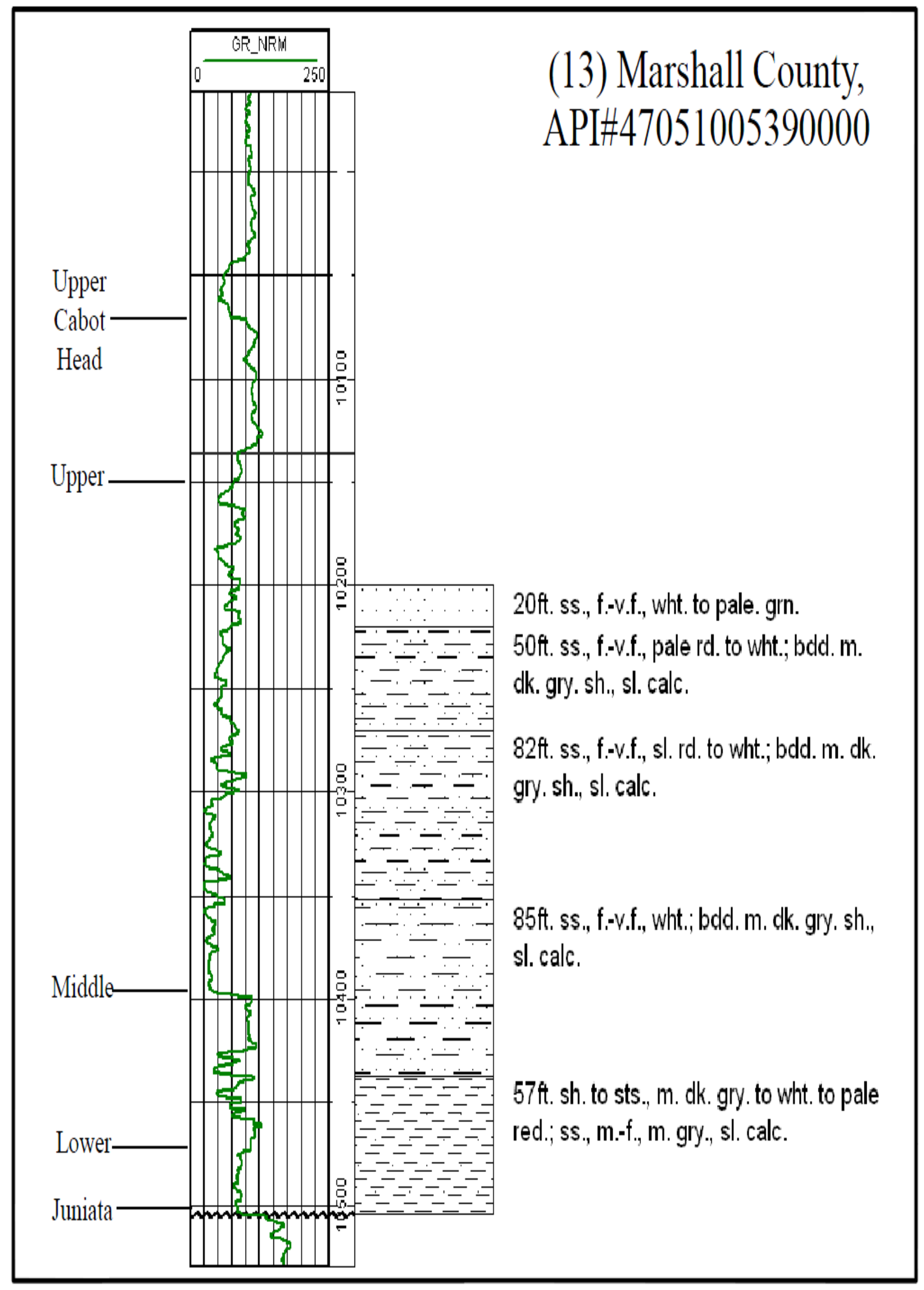




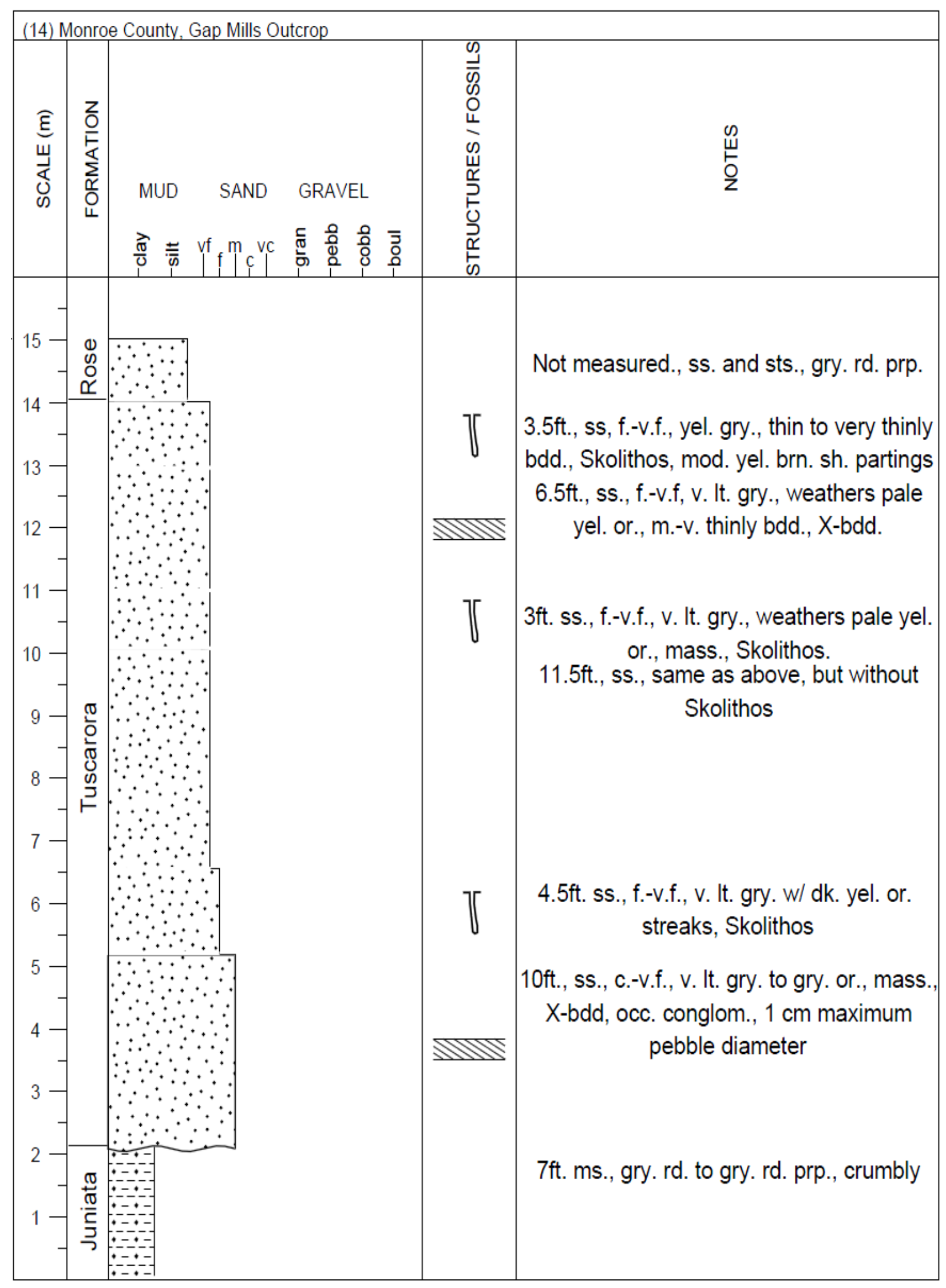




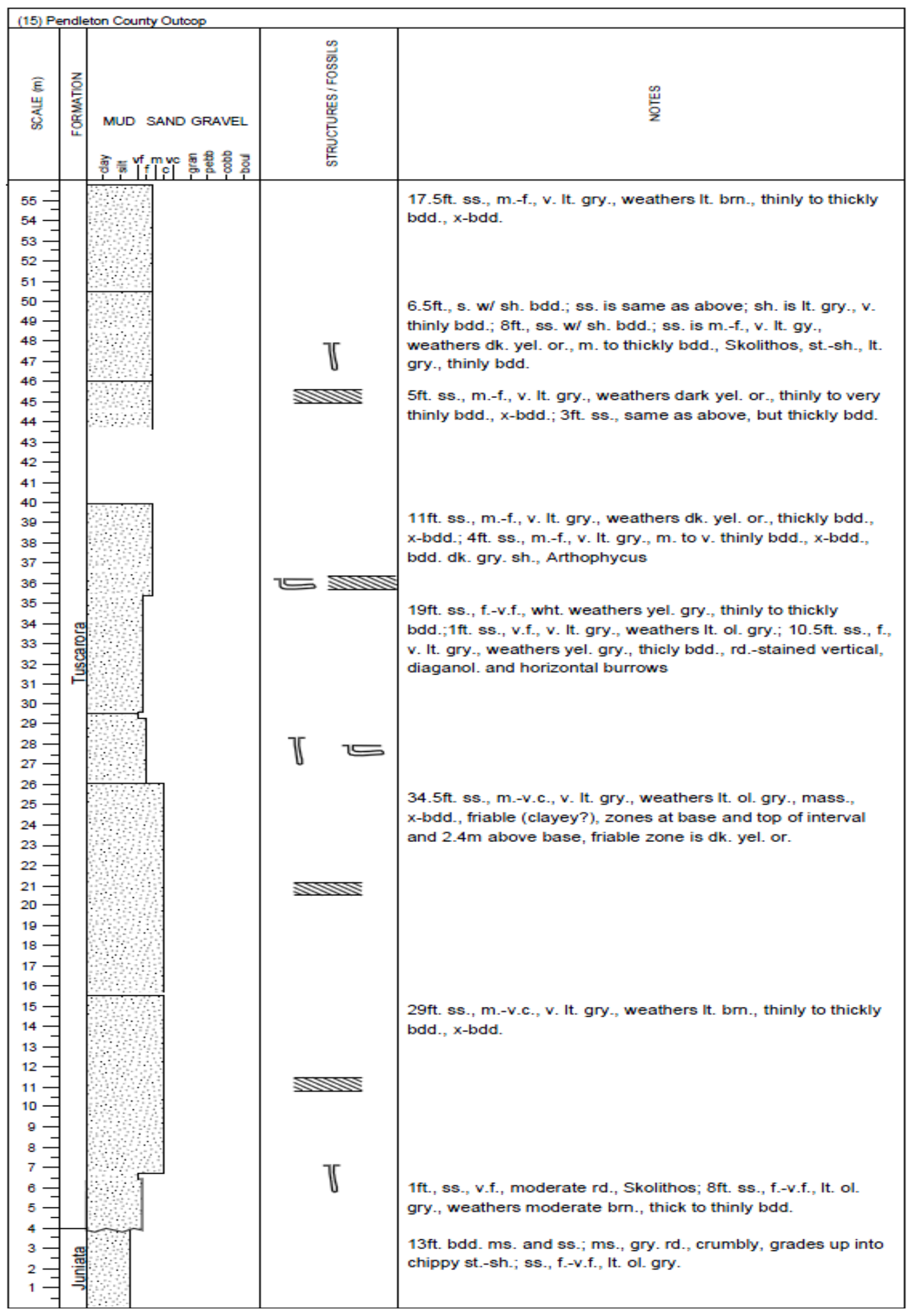




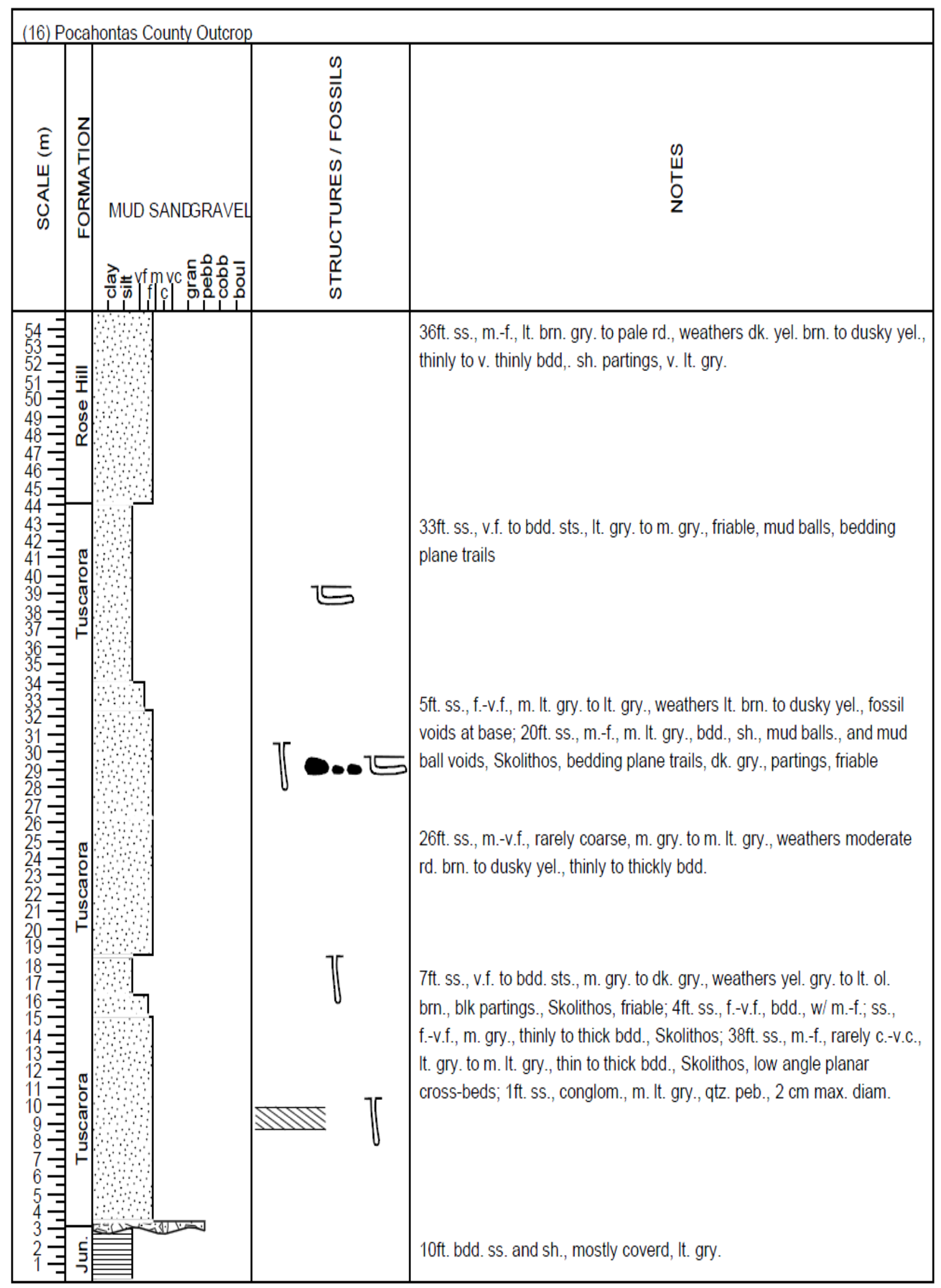




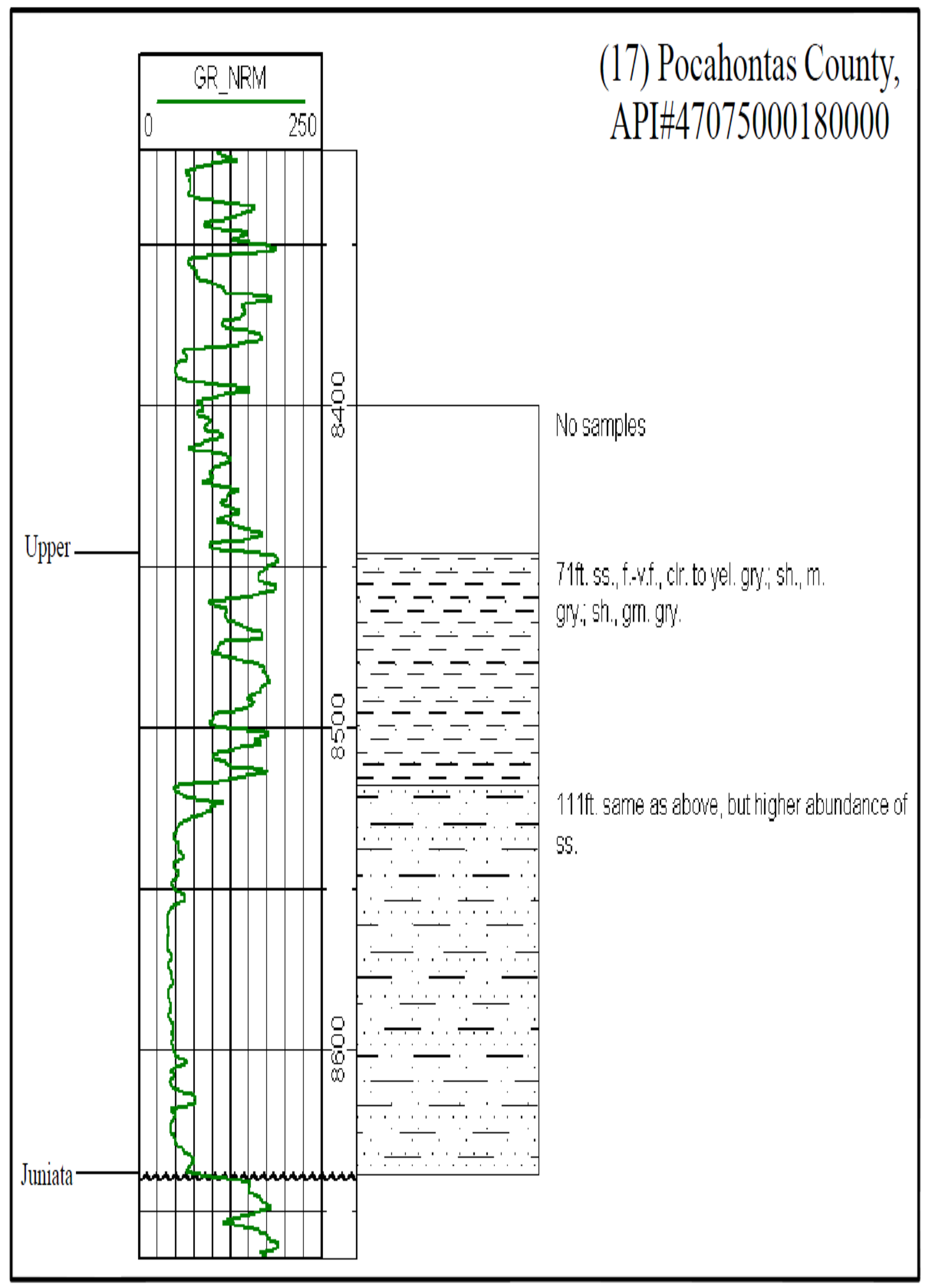




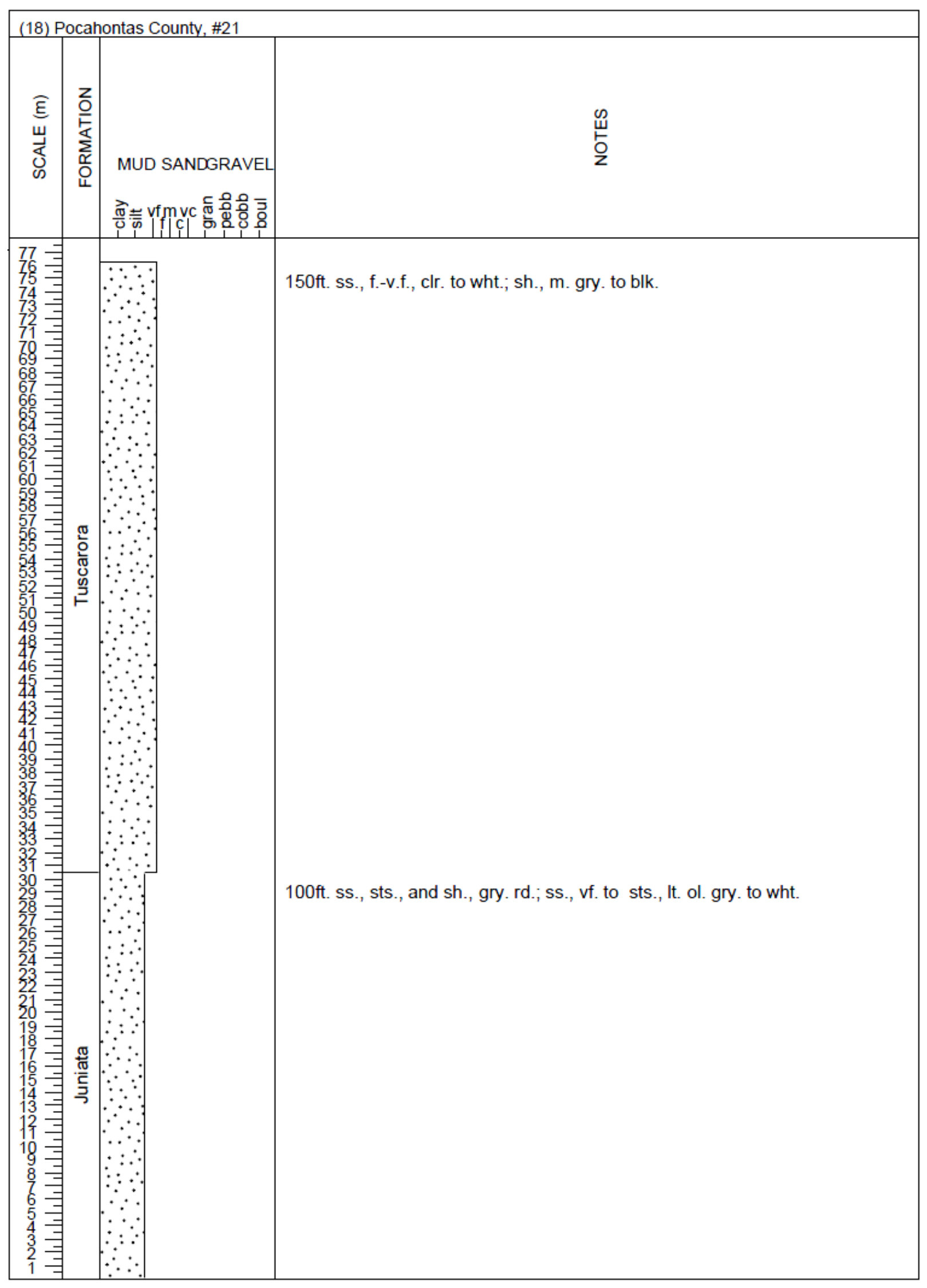




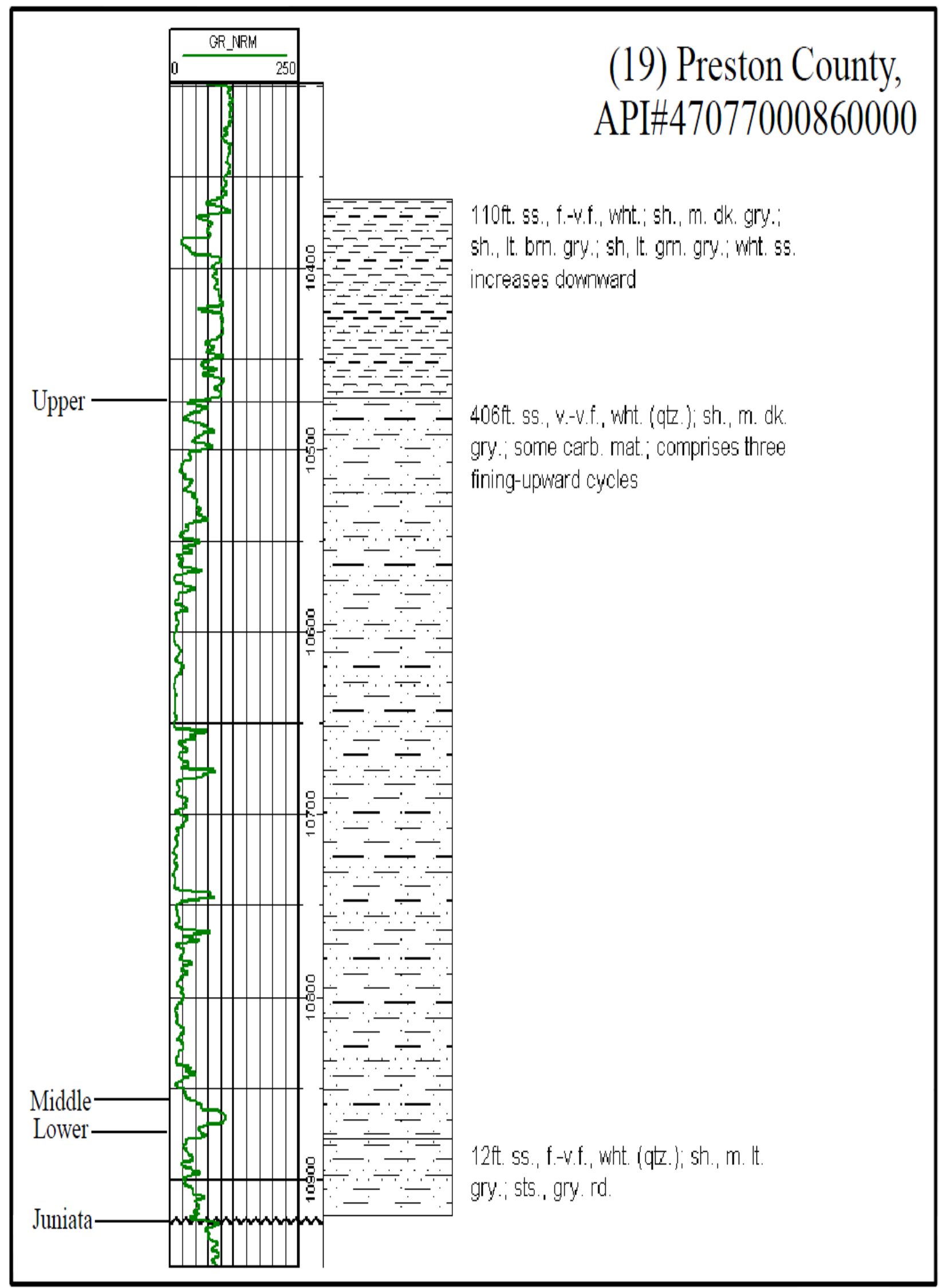




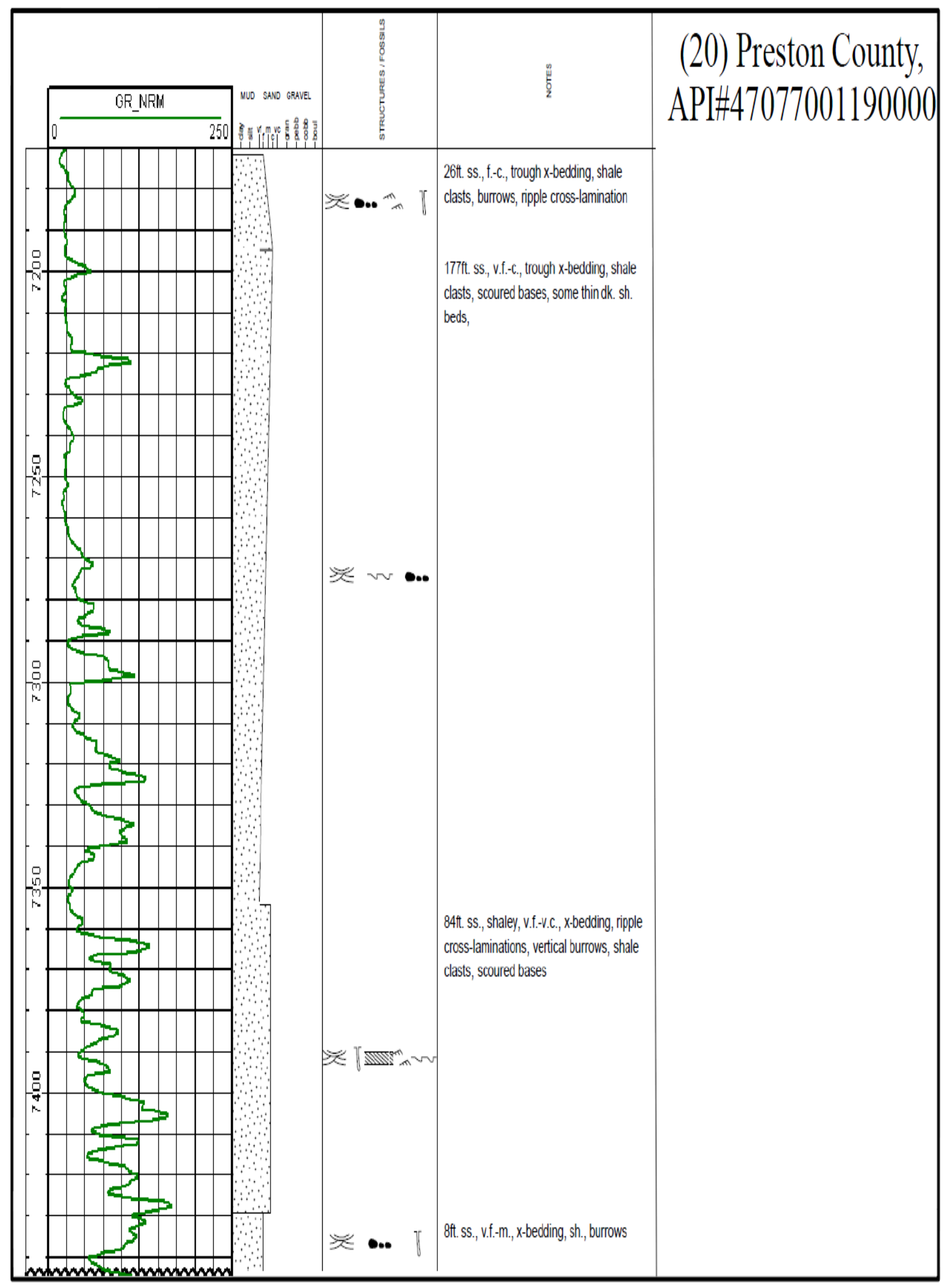




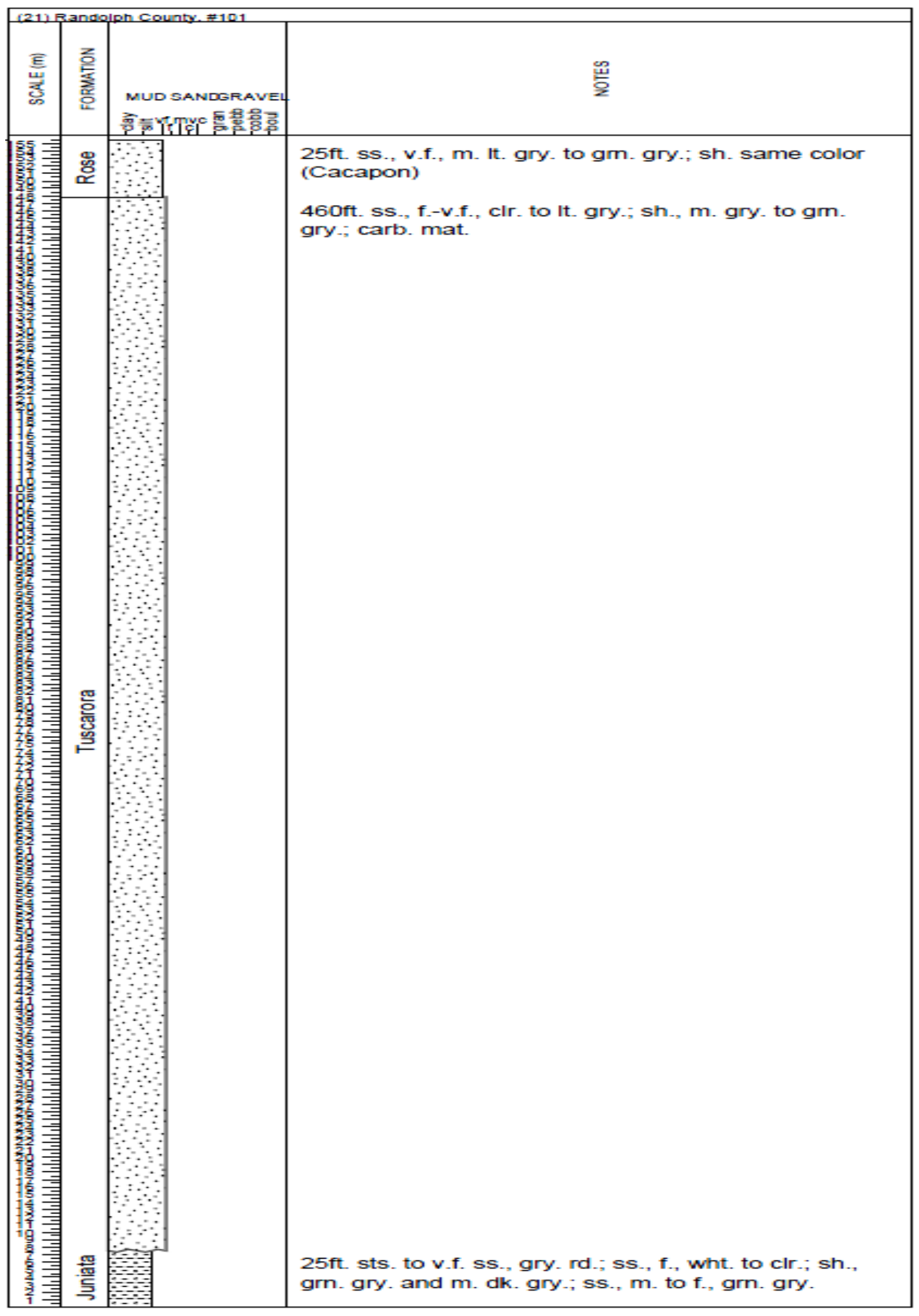




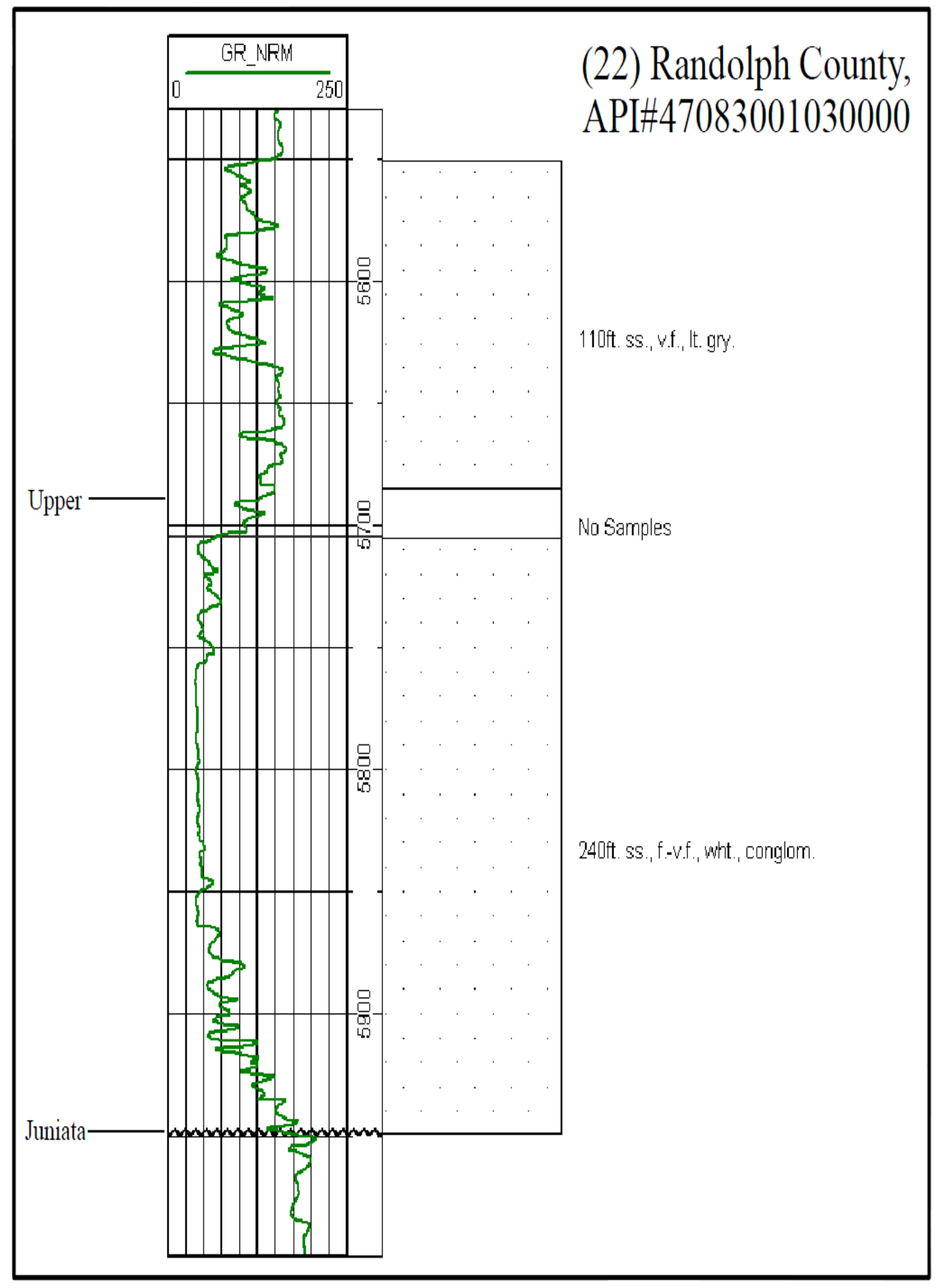




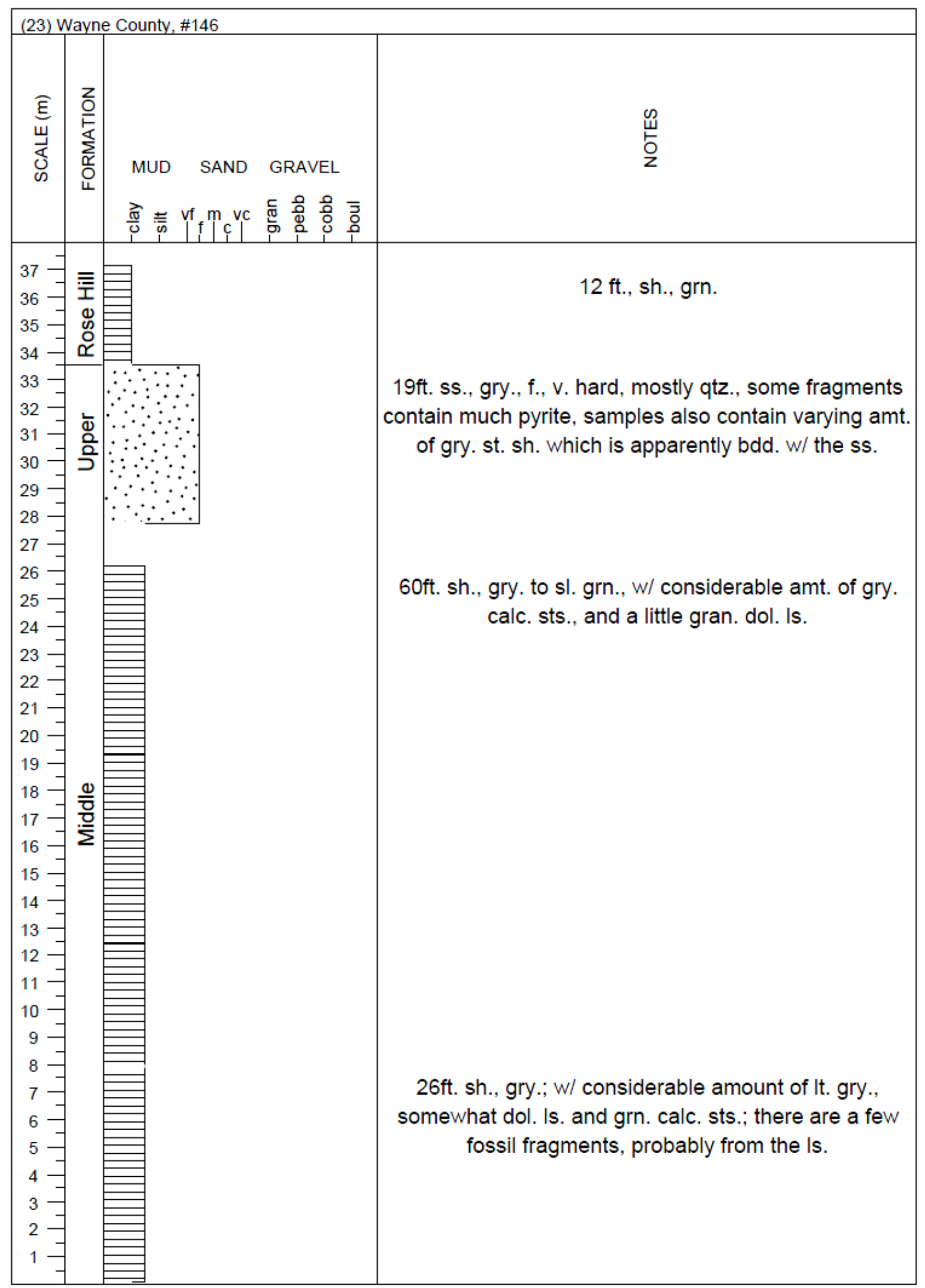




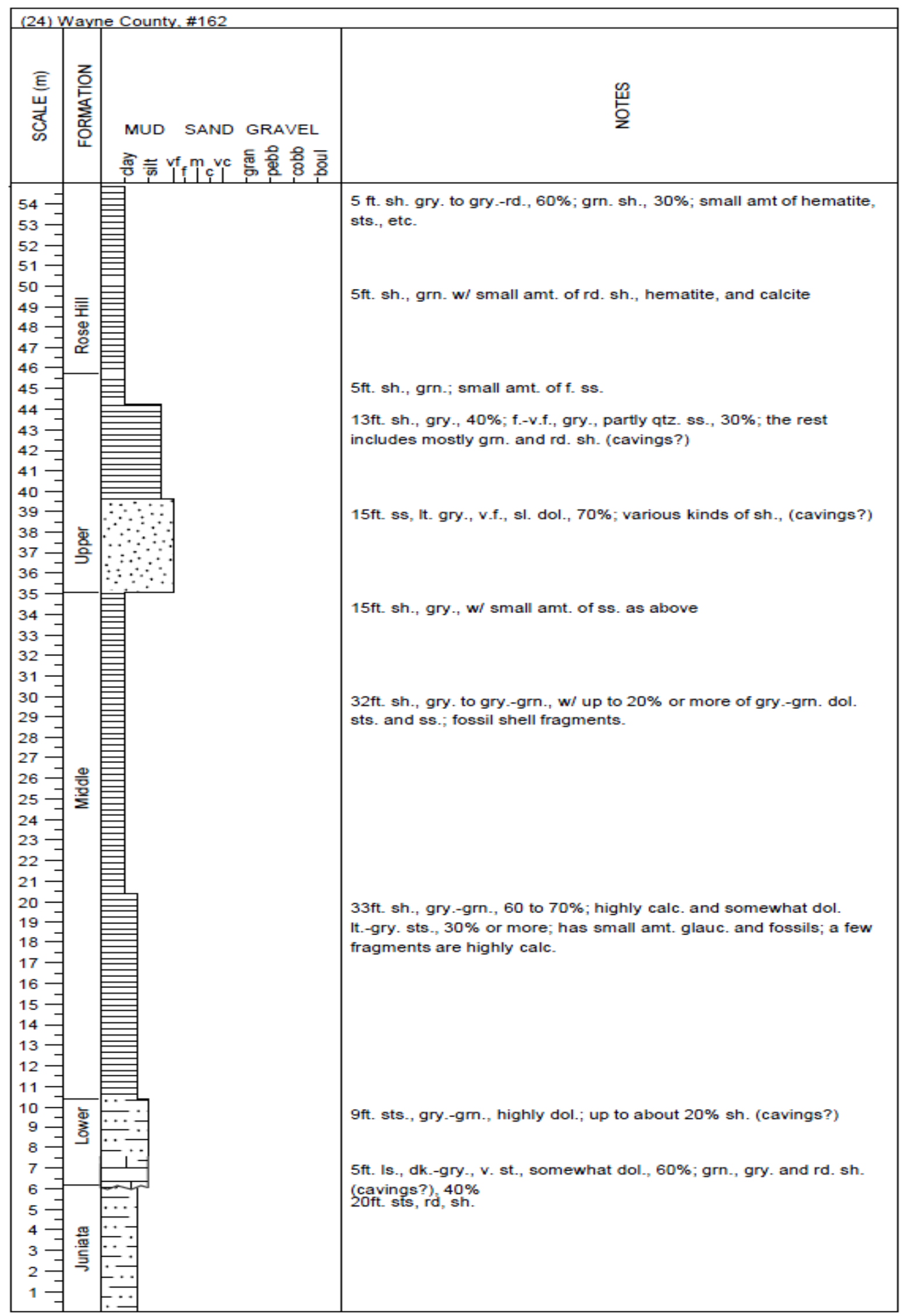




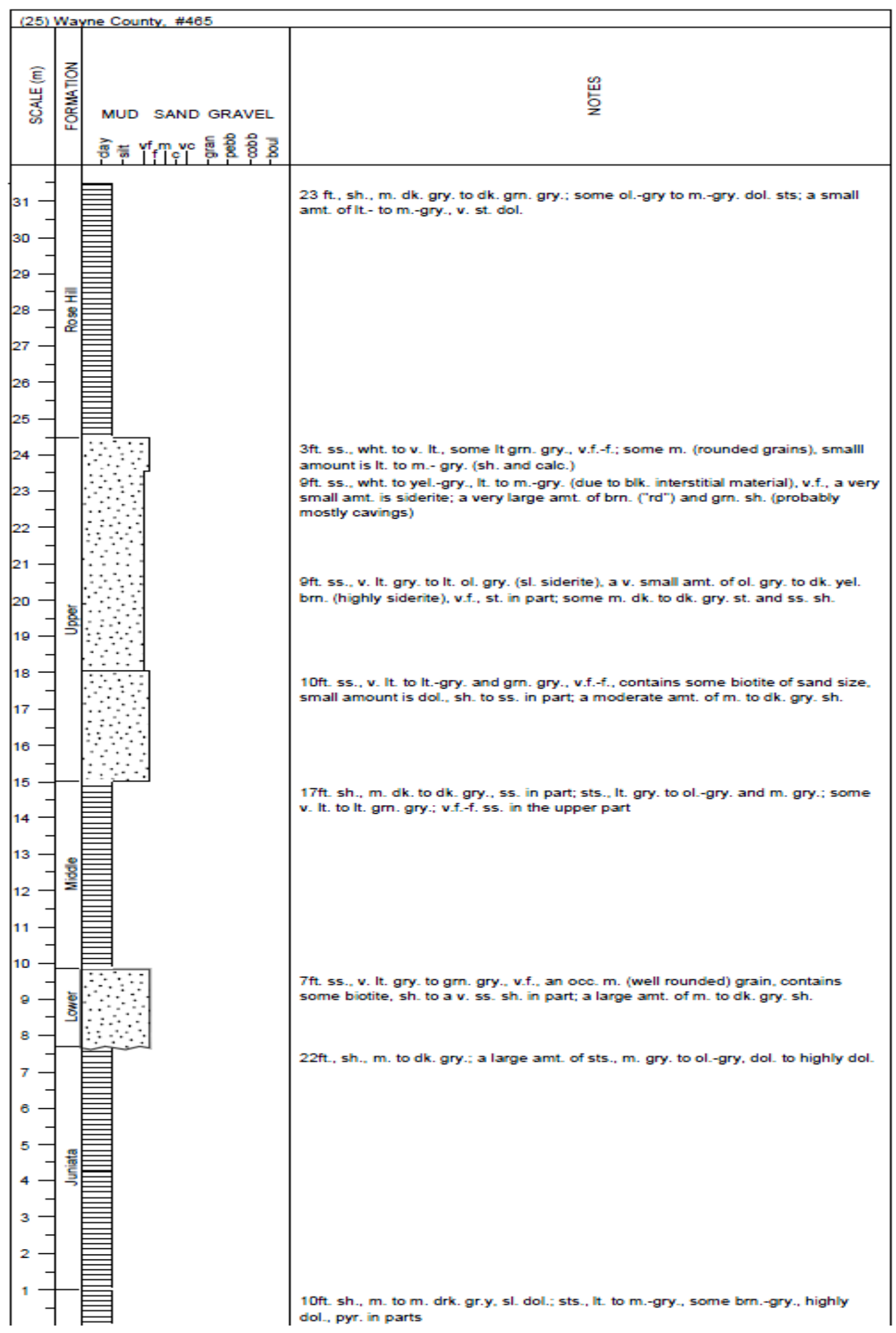




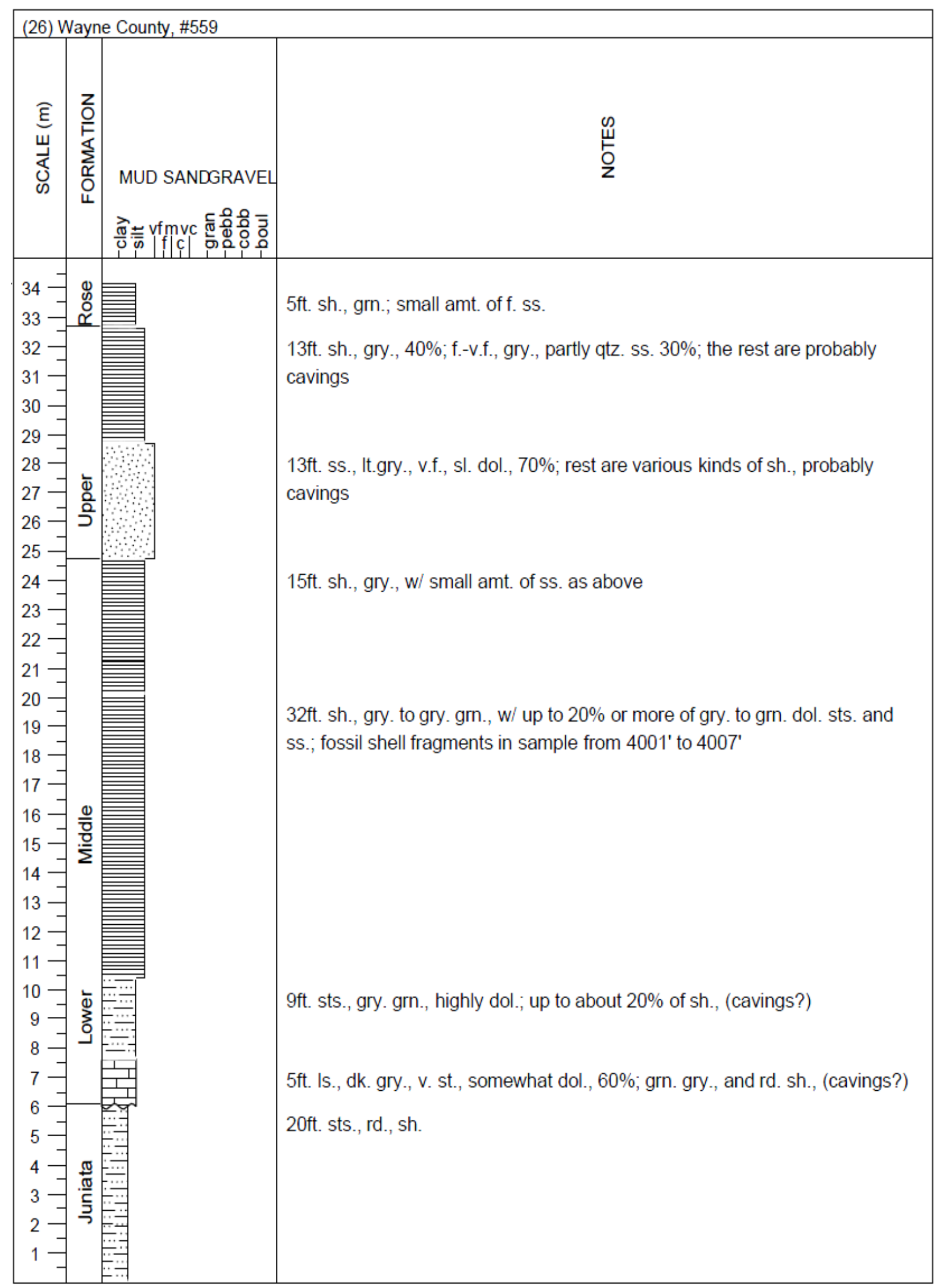




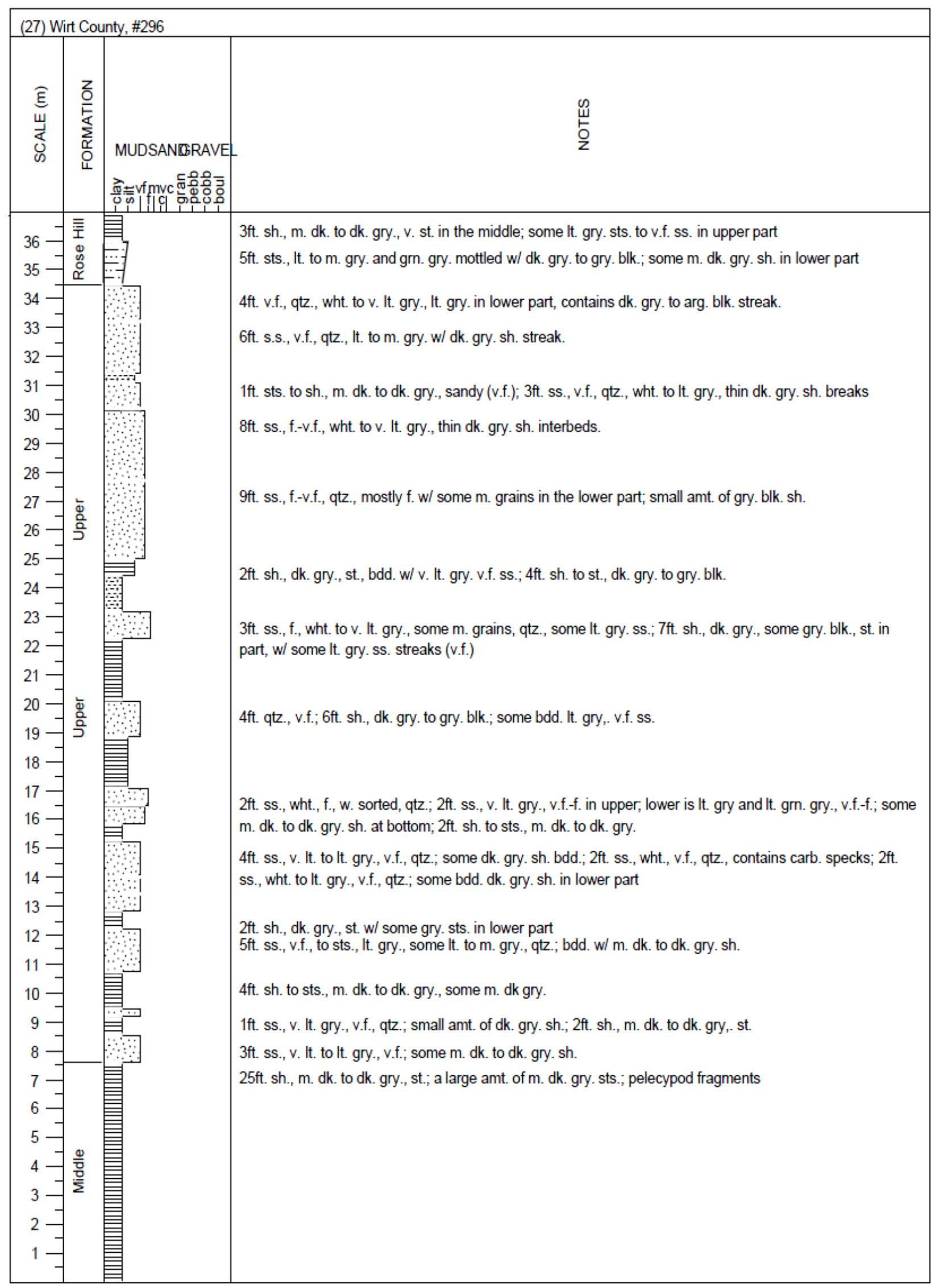




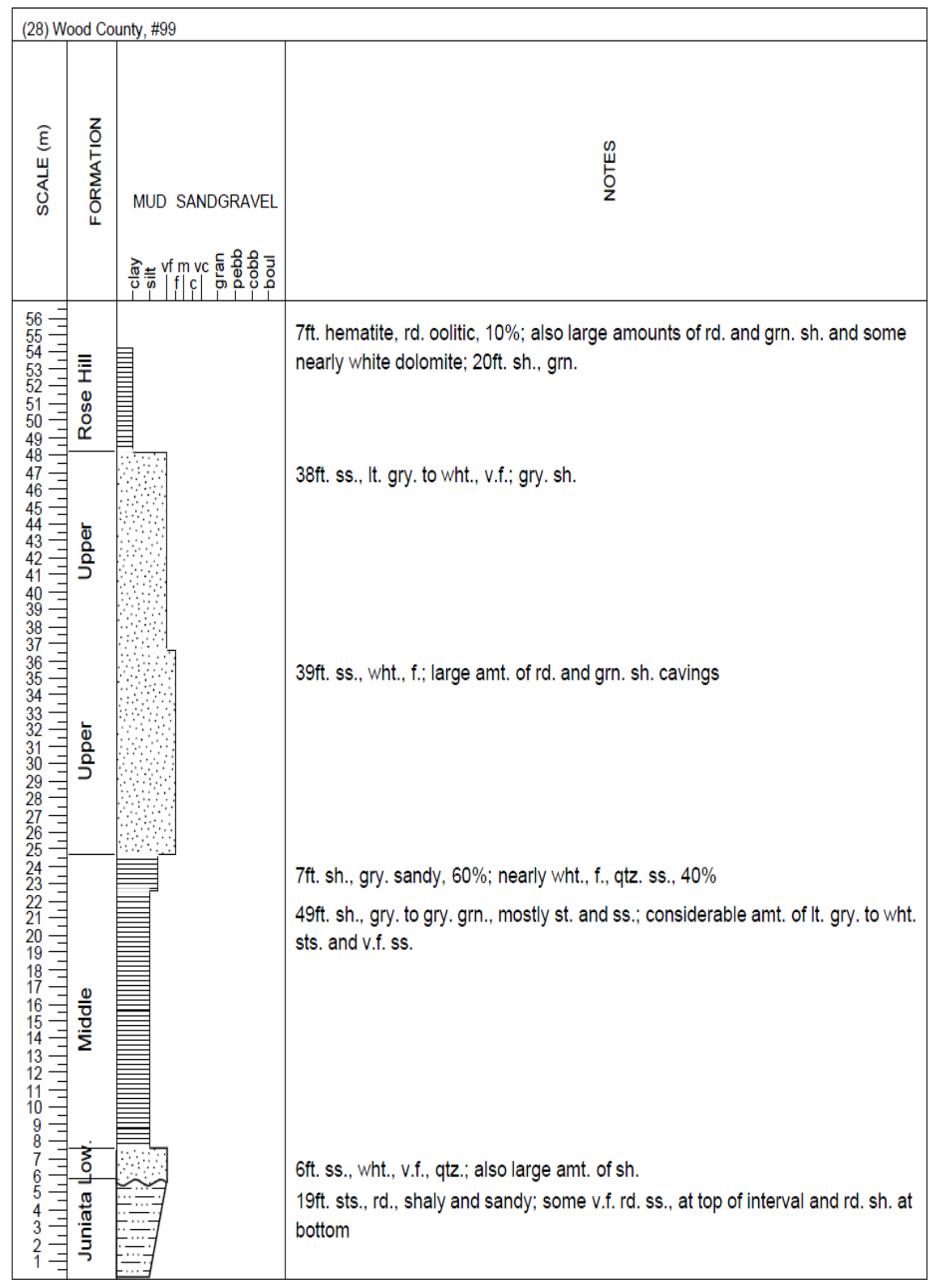




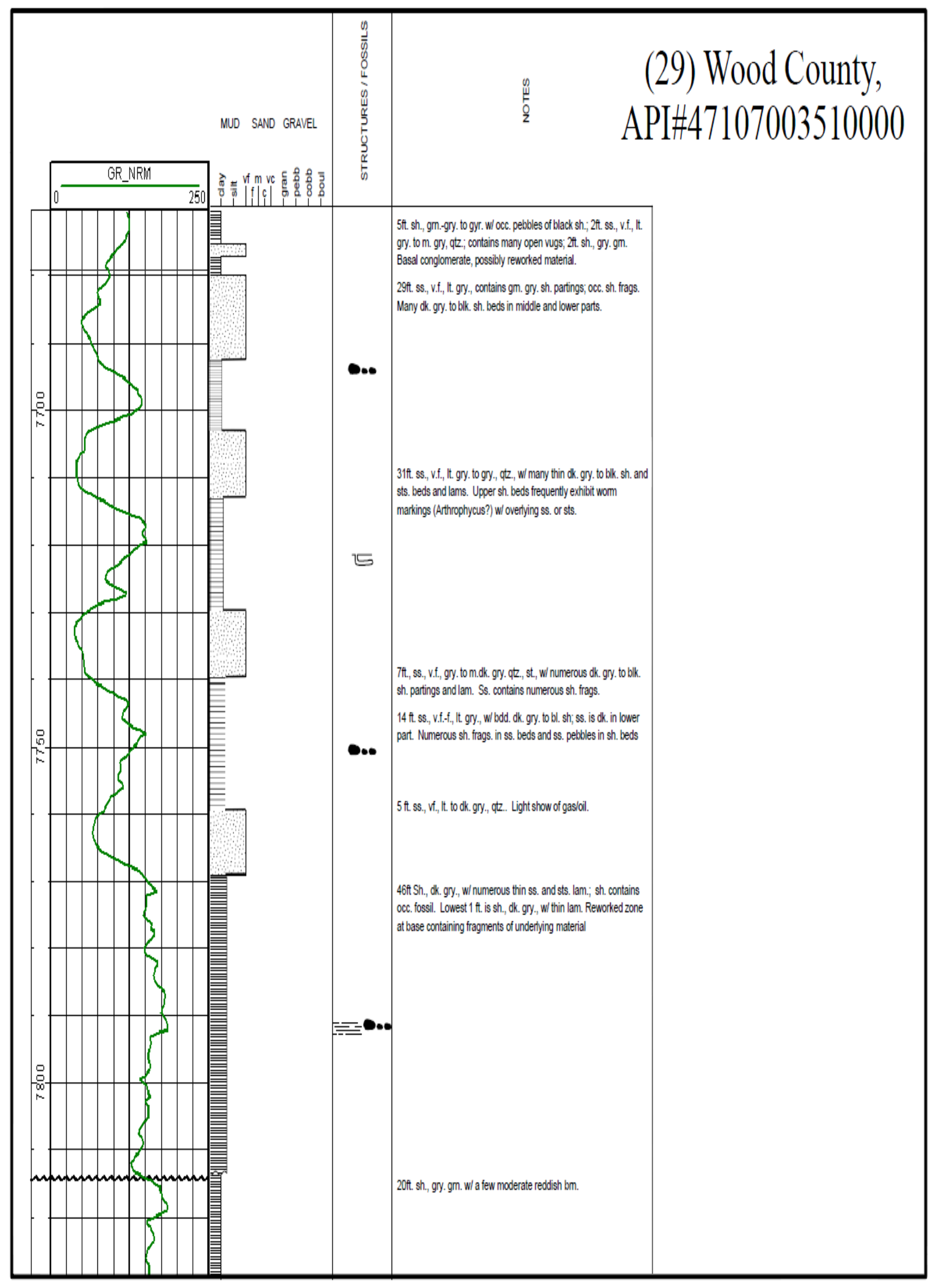




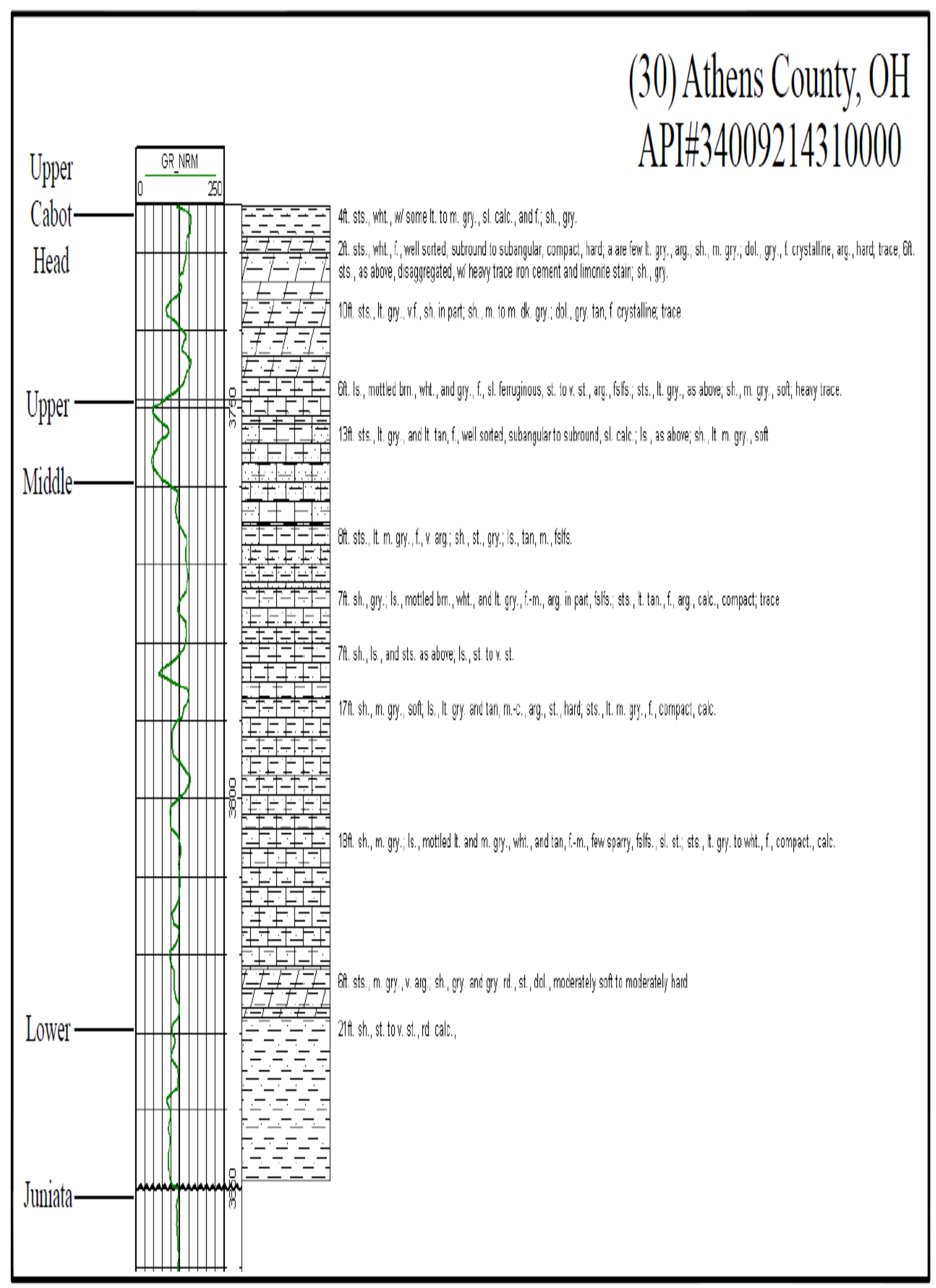




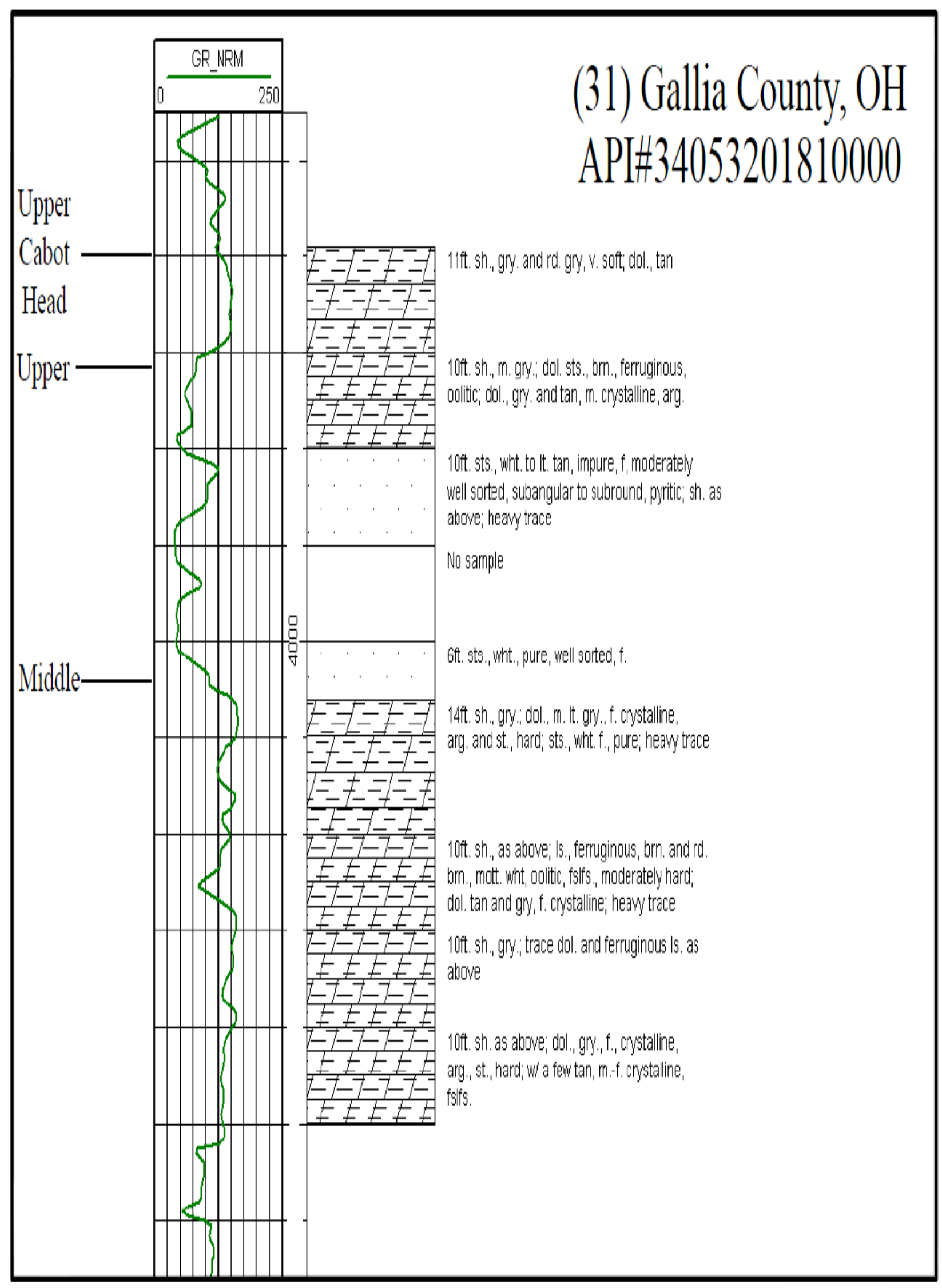

